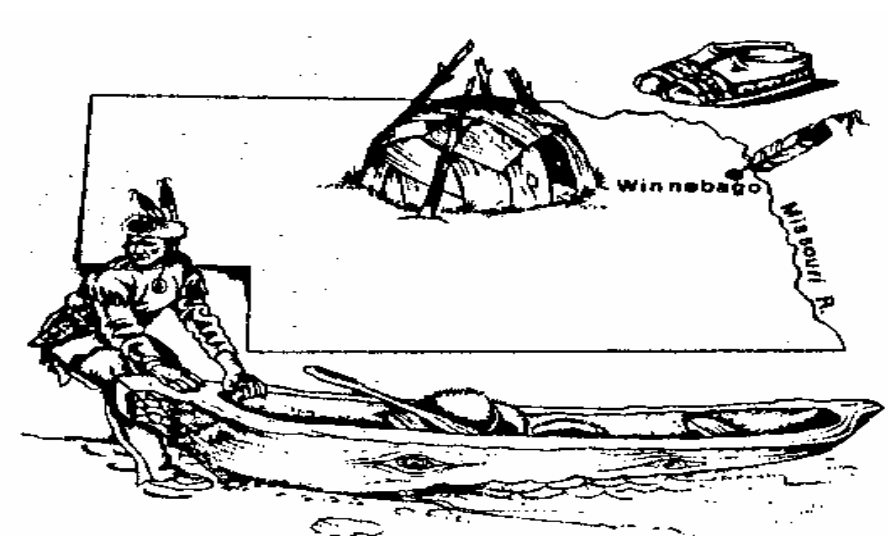

Winnebago Tribe of Nebraska Wind Generation on Winnebago Tribal Lands

Final Report

DE-FG36-06-GO-16024

September 2009

PREPARED BY:

300 W. Clarendon Avenue Suite 215

Phoenix, Arizona 85013

phone: 602.516 .7540

fax: 623.321 .6467

www.RedMtnEnergy.com

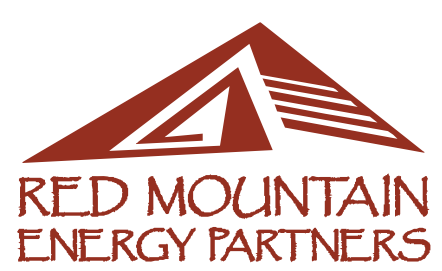




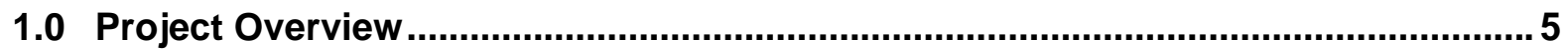

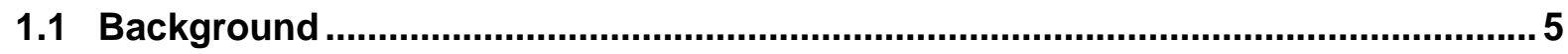

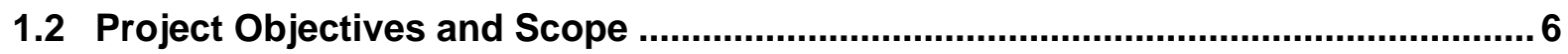

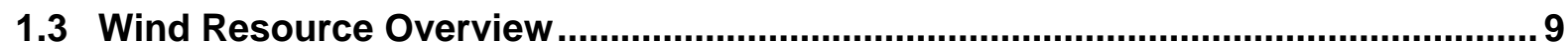

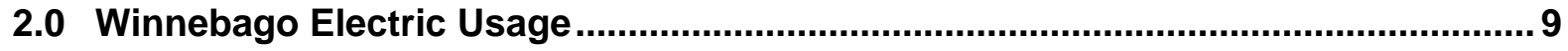

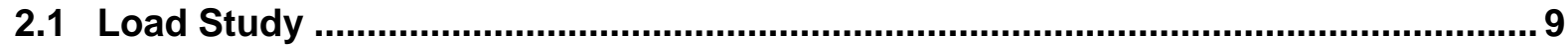

3.0 WinnaVegas Casino: Facility-Scale Wind Project................................................ 10

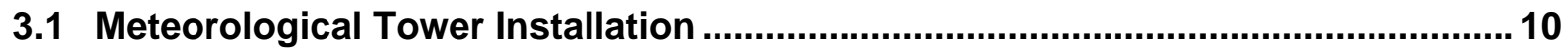

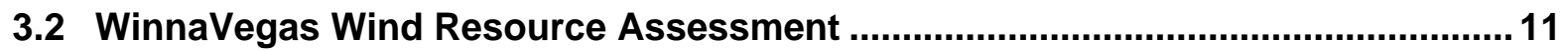

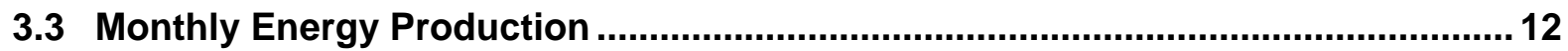

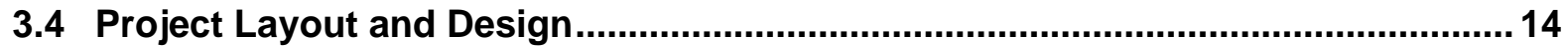

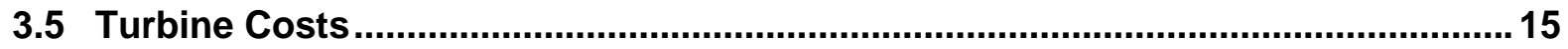

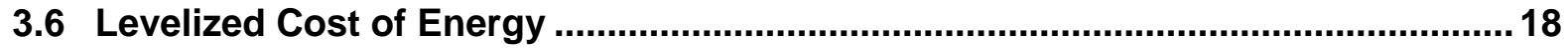

3.7 Woodbury County Rural Electric Cooperative On-Site Generation ....................... 18

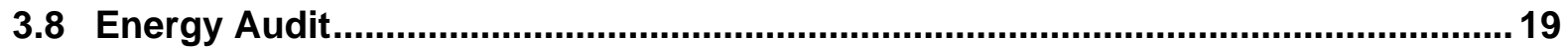

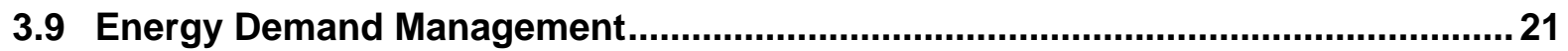

4.0 Large Scale Wind Project Evaluations.............................................................. 22

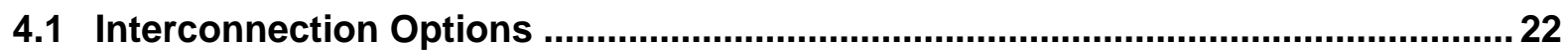

4.2 Western Winnebago: Utility-Scale Wind Project Site .......................................... 25

4.2.1 Met Tower Location and Wind Resource Assessment ................................... 29

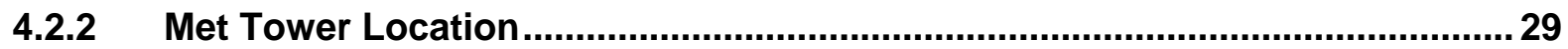

4.2.3 Met Tower Data Assessment ........................................................................... 32

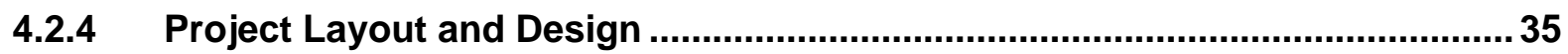

4.2.5 Wind Production and Project Cost Analysis ................................................. 36

4.2.6 Project Feasibility Analysis .......................................................................... 38

4.2.7 Western Winnebago Interconnection ............................................................... 39

4.3 Thunderway: Community-Scale Wind Project ..................................................... 41

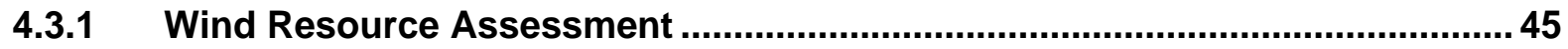

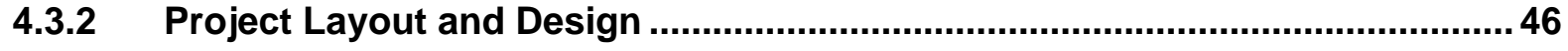

4.3.3 Wind Production and Project Cost Analysis .............................................49

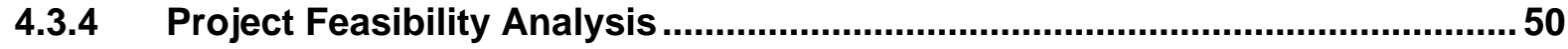

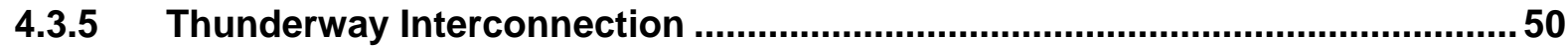


5.0 Resource Impact and Protection ................................................................... 51

5.1 Environmental - Threatened or Endangered Species and Habitat ......................... 51

5.2 Environmental- Wetlands and Protected Areas ................................................... 52

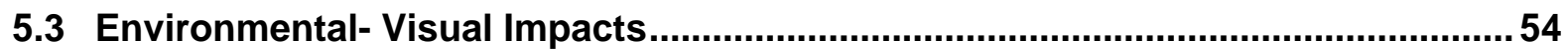

5.4 Environmental- Avoided Greenhouse Gas Emissions ...................................... 57

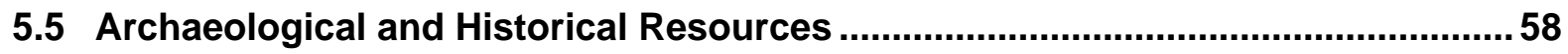

5.6 Initial Environmental Assessment - Western Winnebago.....................................59

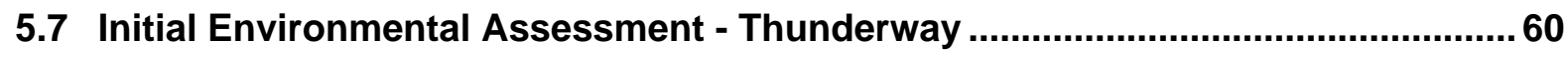

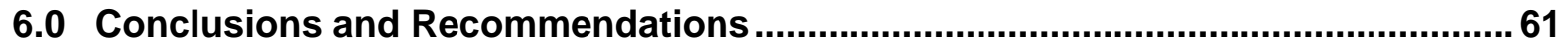

6.1 WinnaVegas Casino Wind Turbine ........................................................................ 61

6.2 Western Winnebago Wind Project............................................................................61

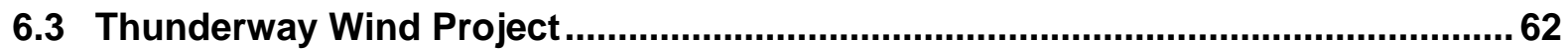

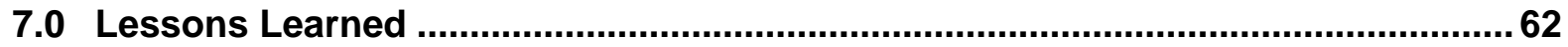

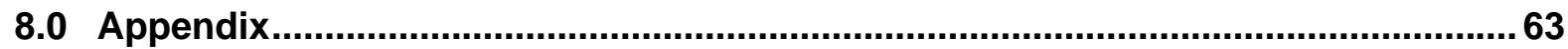

8.1 WinnaVegas Met Tower Site Notes Summary as of October 9, 2008.................... 63

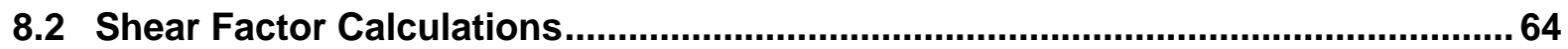

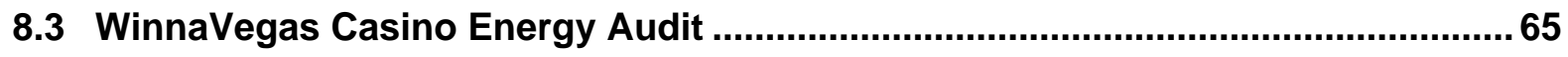

8.4 WinnaVegas Supporting Documents .................................................................. 75

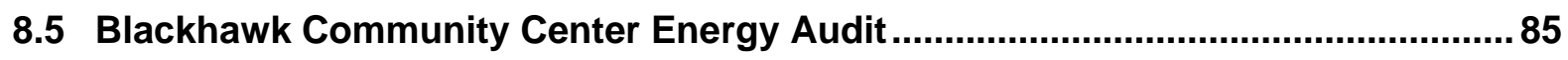

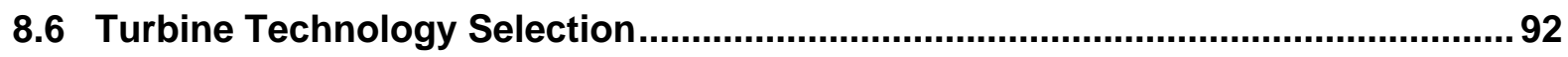

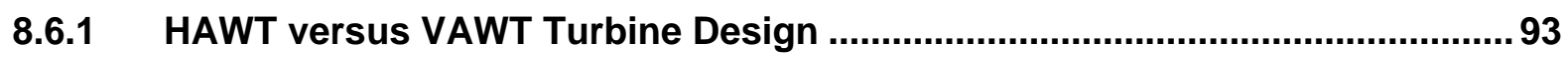

8.6.2 Operation and Maintenance ....................................................................... 94

8.7 2006 Denmark Wind Turbine Production and Maintenance Data............................ 96

8.8 Wind Turbine Suppliers and Resources ................................................................. 98

8.9 Wind Turbine Manufacturing Facilities Near Winnebago........................................ 99

8.10 Crane Equipment Quote ..................................................................................... 100

8.11 Woodbury Electric Rates .............................................................................. 102

8.12 Woodbury Electric Tariff ...................................................................................... 107

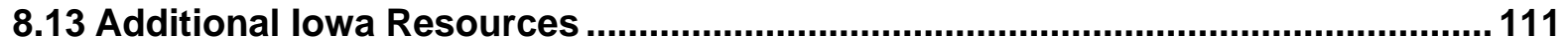

8.14 Nebraska Game and Parks Commission Review.............................................. 114

8.15 Letter Regarding Archeological Sites................................................................ 118

8.16 Conservation Reserve Program .......................................................................... 119

8.17 NPPD Interconnection Request .......................................................................... 122 


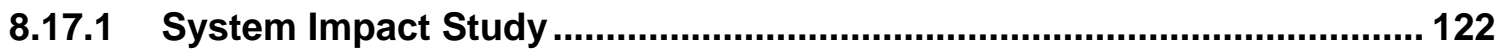

8.17.2 Large Generator Interconnection Agreement (LGIA)........................... 125

Important Notice: This study has been prepared by Red Mountain Energy Partners (Red Mountain) for the Winnebago Tribe. This document shall be considered confidential and proprietary, and is intended for the use of the Winnebago Tribe only, unless otherwise specifically authorized by the Winnebago Tribe in writing.

This study has been prepared from information gathered by Red Mountain, which makes no guarantees as to the accuracy of its economic and financial assumptions and projections. No part of this Study should be construed as legal, financial or tax advice. The Winnebago Tribe should consult professional legal, financial or tax advisors on such matters. 


\section{$1.0 \quad$ Project Overview}

\subsection{Background}

The Winnebago Reservation of the Winnebago Tribe of Nebraska (Winnebago) is located in the northern half of Thurston County in northeastern Nebraska, and covers approximately 120,000 acres of cropland, woodland, and pasture. The County's total population (as of early 2004, inclusive of the Tribal members) was just over 7,000. Approximately 2,600 people live on the reservation. The closest metropolitan areas to the Reservation are Omaha, Nebraska, located 78 miles to the south, and Sioux City, lowa, located 19 miles to the north. The largest community on the Reservation is the Village of Winnebago. The closest airport is located in the nearby town of Pender, Nebraska.

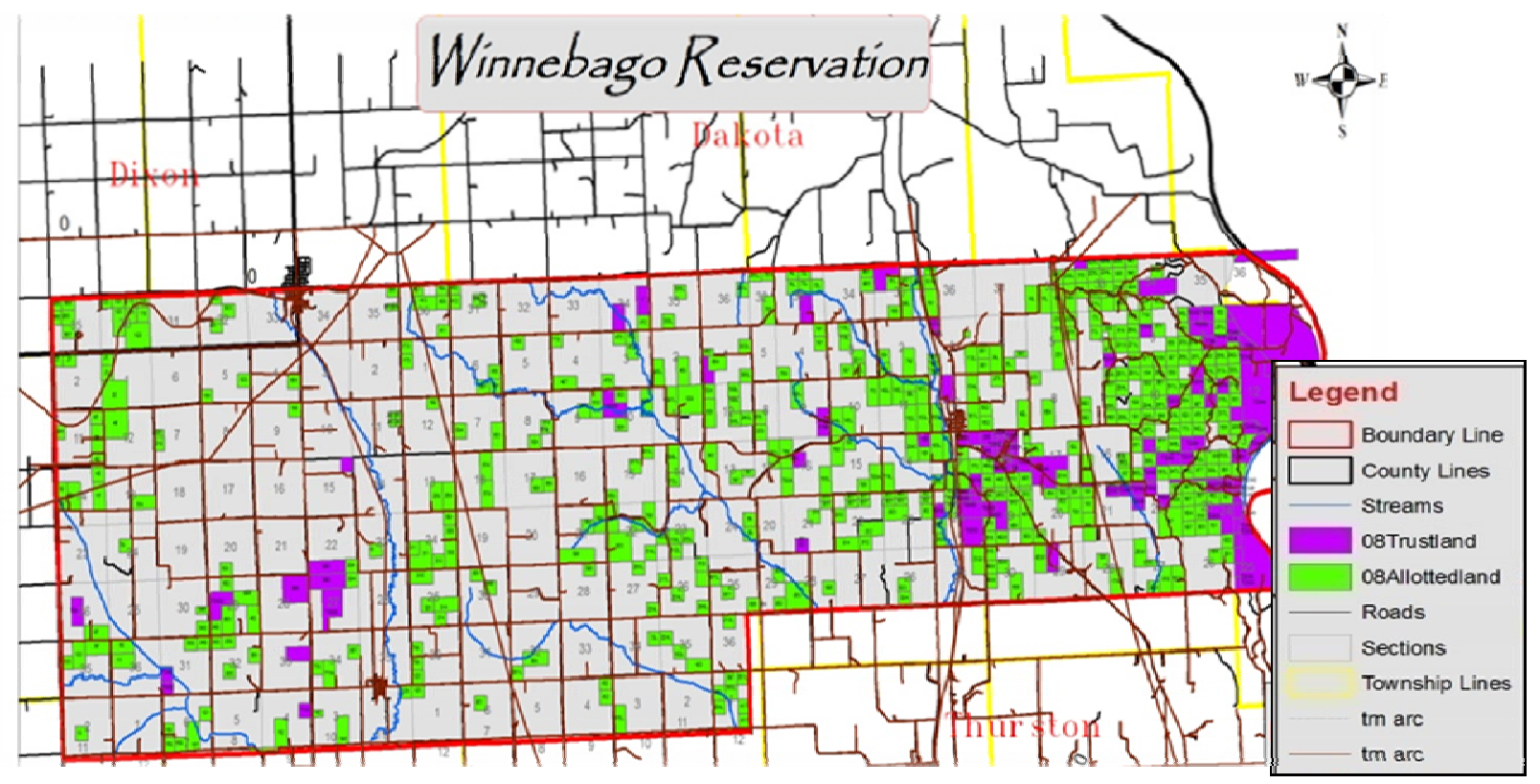

Figure 1.1-1 Map of Winnebago Reservation

The Winnebago Village is home to most Winnebago Tribal members and accounts for almost thirty percent of the Reservation's resident population. The Tribe and individual Tribal members own approximately one-third of the Reservation acreage. Non-Tribal members, however, farm much of the Indian land. Important sectors of employment on the Reservation include health and education services, manufacturing, agriculture, public administration, and retail trade. The Winnebago Tribe's trust lands and holdings in lowa are approximately 1,800 acres at present with plans to extend ownership as development occurs. The WinnaVegas Casino located on trust land east of the Missouri River, in Sloan, lowa, and a Convenience Store/Gas Station complex in the village of Winnebago play a significant part in the general economy both in employment and revenue for the Tribe. Future plans include a casino expansion project for the WinnaVegas, with a Convention Center, Hotel and RV Park. These expansion plans have caused the Tribe to examine the vital role that energy plays in supporting growth and economic development. Tribal leadership believes it needs to play a more active role in assuring that safe, reliable, affordable, and clean energy is available to meet the Reservation's present and future needs. In considering alternatives to meet these needs, the Tribe strives to maintain 
alignment between its growth goals, and cultural values of sustainable, environmental stewardship, which have created interest in examining options for renewable generation.

Winnebago is served by several utilities: Nebraska Public Power District (NPPD), Burt County Public Power District (Burt County), and Woodbury County Rural Energy Cooperative (Woodbury REC).

From April 20, 2001 to April 16, 2002, the Tribe conducted a wind resource analysis with the use of a 20-meter anemometer provided through the Department of Energy's ("DOE") Native American Anemometer Loan Program. The anemometry was installed at a site adjacent to the WinnaVegas Casino, roughly four miles west of Sloan, lowa, at an elevation of 1070 feet. Because the Tribe envisioned a small turbine to serve only the casino load, the anemometer was placed on the casino campus. No terrain analysis or wind meteorology was conducted to optimize the location of the tower. The wind data collected was evaluated and an economic analysis was conducted for a potential wind turbine project. The average annual wind speed at 20 meters was $5.2 \mathrm{~m} / \mathrm{s}$, or 11.5 miles per hour.

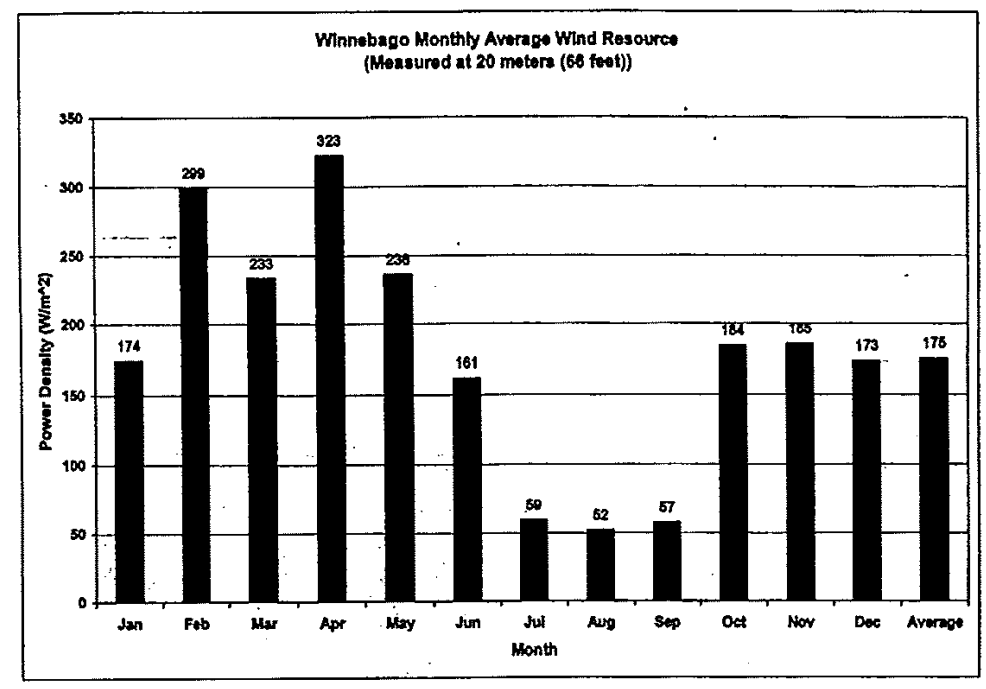

Figure 1.1-2, 20 Meter Wind Data

A National Renewable Energy Laboratory (NREL) report to the Tribe dated September 24, 2002, indicated that a wind turbine of about $190 \mathrm{~kW}$ would "generate an amount of electricity roughly equal to the consumption of the casino, and be "technically reasonable .... but economics marginal and depend heavily upon the details of the electric tariff structure under which the casino operates". In its brief analysis, NREL assumed that the lowa monthly net metering requirement would apply to WinnaVegas, which was not the case.

\subsection{Project Objectives and Scope}

This study was funded by the Department of Energy ("DOE") Tribal Energy Program and intended to educate and provide guidance regarding wind energy development opportunities on Winnebago Lands. The purpose of the study was to determine feasibility of potential wind development on the Winnebago Reservation:

- Study and analyze wind resources 
- Analyze and make preliminary recommendations on where it is feasible and not feasible to continue investigation or pre-development activities

- Provide the Winnebago community information to determine whether wind development is of further interest

- Provide tools needed to pursue potential wind project development

Consistent with the Winnebago Tribal Vision \& Strategic Energy Plan, the overarching objective in conducting this study was to utilize its results to advance the Tribe's near-term energy management objectives. In general, the Tribe seeks to employ energy management as a partial means to accomplish its goals for (i) improved health, welfare, self-sufficiency, and creation of enhanced quality of life for the Winnebago People; and (ii) economic and community development goals. One of the key near-term goals articulated in the Tribe's strategic energy plan is to "identify and act upon opportunities for development of Tribal renewable energy resources that meet Tribal needs, consistent with the Tribe's mission to preserve resources, cultural heritage, traditional values, and beliefs". Thus, development of renewable generation is a key component of the Tribe's overall energy management approach.

The Tribe's initial objectives for this project were to:

- Support Tribal energy planning and project development capacity

- Develop a project planning and oversight framework

- Analyze Tribal loads and renewable resources, power markets and delivery options

- Identify potential Winnebago renewable energy projects

- Perform a fatal flaw analysis re: technology, system and environmental impacts

- Support Council decision-making regarding energy project development

The Tribe proposed to carry out the study effort in several sequential and parallel stages, with Tribal Council Secretary Louie Houghton acting as Project Director and the Winnebago Tribal Energy Committee acting as an advisory body.

The project was ultimately comprised of the following primary tasks and covered facility-scale, community-scale and commercial-scale wind project opportunities:

- Capacity Building

- Project Identification

o Load Assessment

o Resource Monitoring

o Power Markets \& Delivery

o Community \& Stakeholder Outreach

- Technology Selection and System Design 
- Environmental Evaluation

- Project Economics

In FY 2006, DOE provided partial funding for this Project to the Winnebago; less than the amount requested for the proposed and awarded Project Scope of Work. For that reason, the project was extended over a multi-year period, as summarized below:

- The original application was submitted in February 2005

- DOE announced that Winnebago had been selected for negotiations in January 2006, and through that process, DOE indicated that the project would be eligible for first-year funding only

- In early 2008, DOE revised its commitment to include full funding, as available

The initial work on this DOE-funded project focused primarily on the potential WinnaVegas Casino wind project, utilizing an NREL-provided 50-meter met tower constructed on the WinnaVegas Casino campus for further wind studies. However, a number of factors caused Winnebago to consider the possibility of larger-scale generation, with the possibility of power export:

- Wind data later made available to the Winnebago through NREL and the Nebraska State Energy Office indicated even greater wind resources: as high as Class 4 in other areas on the Winnebago Reservation, and as high as Class 6 in the surrounding area

- Technology advances in turbine design have improved power output efficiency and reduced costs; Improved gearbox assembly designs, intrinsic VAR compensation, and improved blade designs have improved project economics, even for lower wind speeds

- The Winnebago Tribal Council had also expressed interest in evaluating other renewable resources and possible projects, including solar, biomass, geothermal and biofuels potential 


\subsection{Wind Resource Overview}

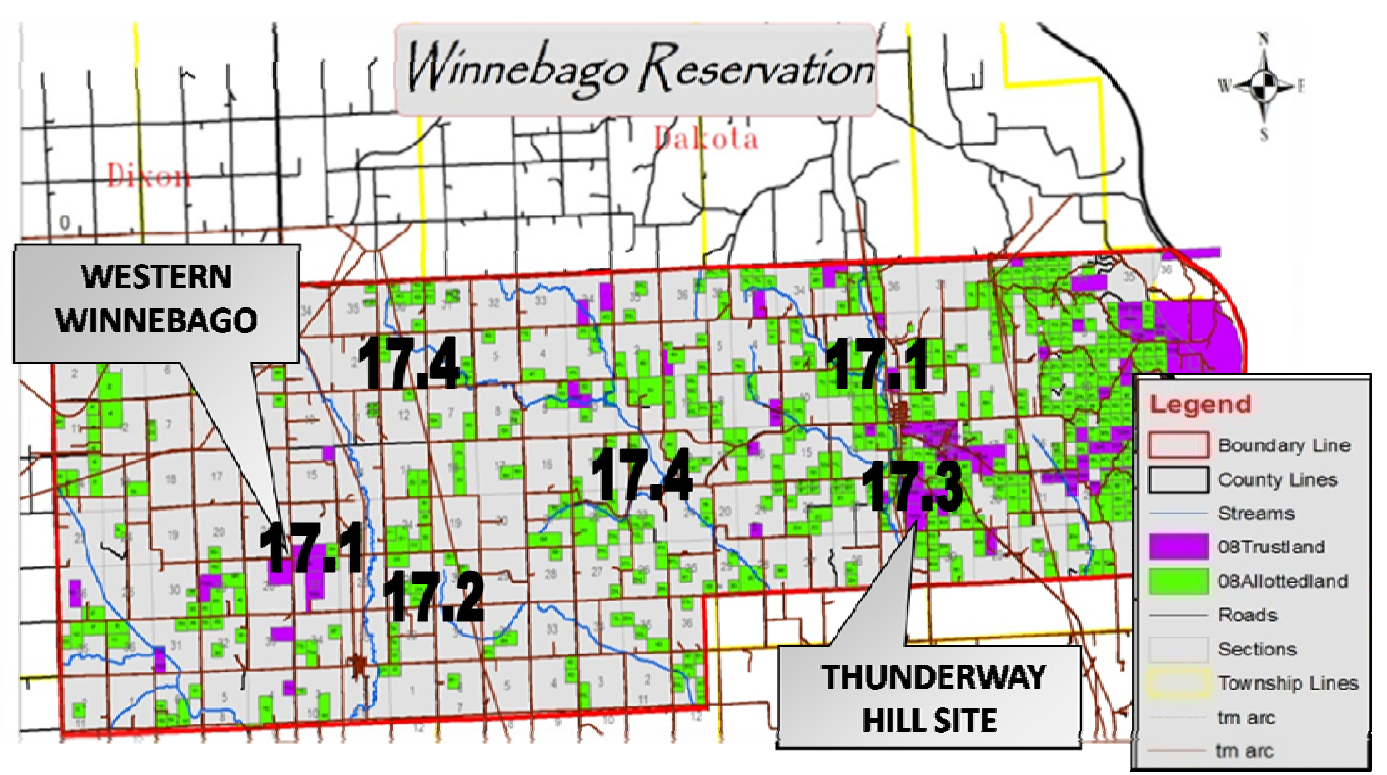

Figure 1.3-1, Winnebago Wind Resource Map

In prior discussions with NREL personnel, potential wind project sites were identified on Winnebago fee and trust lands. Figure 1.3-1 identifies the locations of these sites and estimated wind speeds in miles per hour. These sites were selected based on wind speeds, fee/trust land availability and proximity to transmission. Wind speeds were provided by Nebraska Public Power District's WindLogics consultants and reflect estimates at 80 meter hub heights.

\subsection{Winnebago Electric Usage}

\section{$2.1 \quad$ Load Study}

During 2006 and 2007, electric usage data was collected for thirteen Winnebago facility accounts (WinnaVegas Casino, seven NPPD accounts and four Burt County accounts). Nonresidential energy requirements were derived based upon individual electricity bills, and residential and nonresidential annual hourly loads combined to summarize annual electric load as shown in Figure 2.1-1, and to develop a composite load shape for the entire reservation. 
Figure 2.1-1, 2007 Energy Usage and Electric Demand

Winnebago Tribe of Nebraska

2007 Rate Class Populations, Energy Usage, and Electric Demand

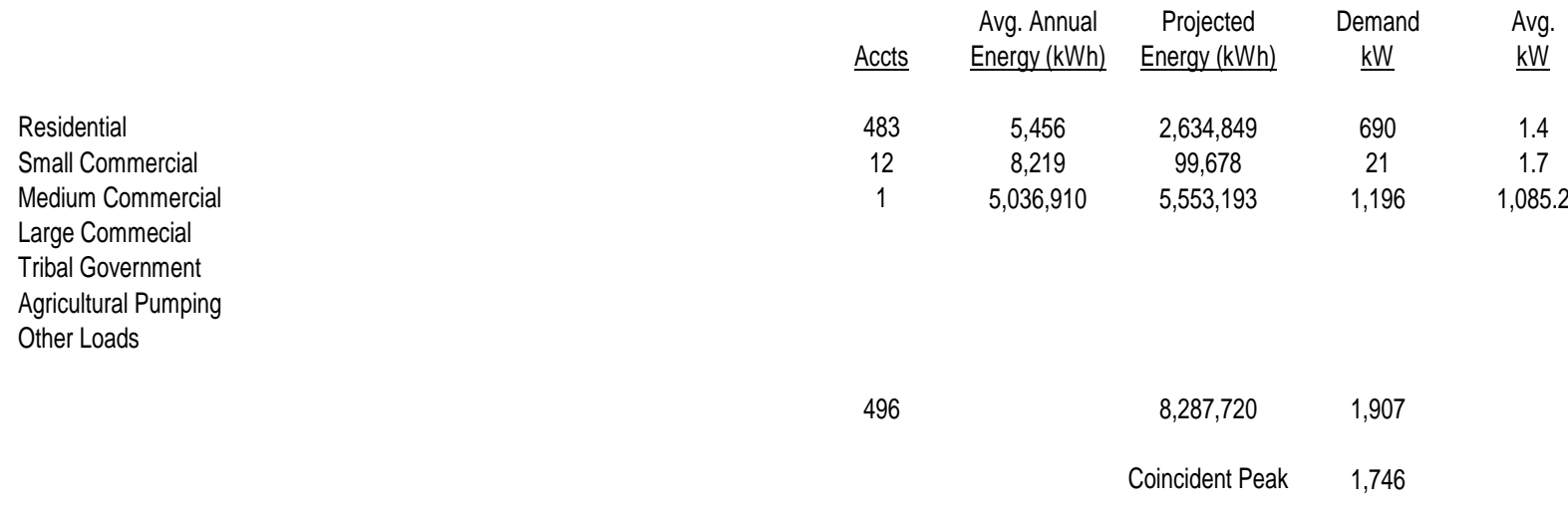

Winnebago annual energy consumption patterns, prototypical building type usage patterns, and residential energy consumption projection data was utilized to develop a 20-year projection of Winnebago reservation electric usage as shown in Figure 2.1-2.

Figure 2.1-2, Projected Winnebago Electric Usage in kWh

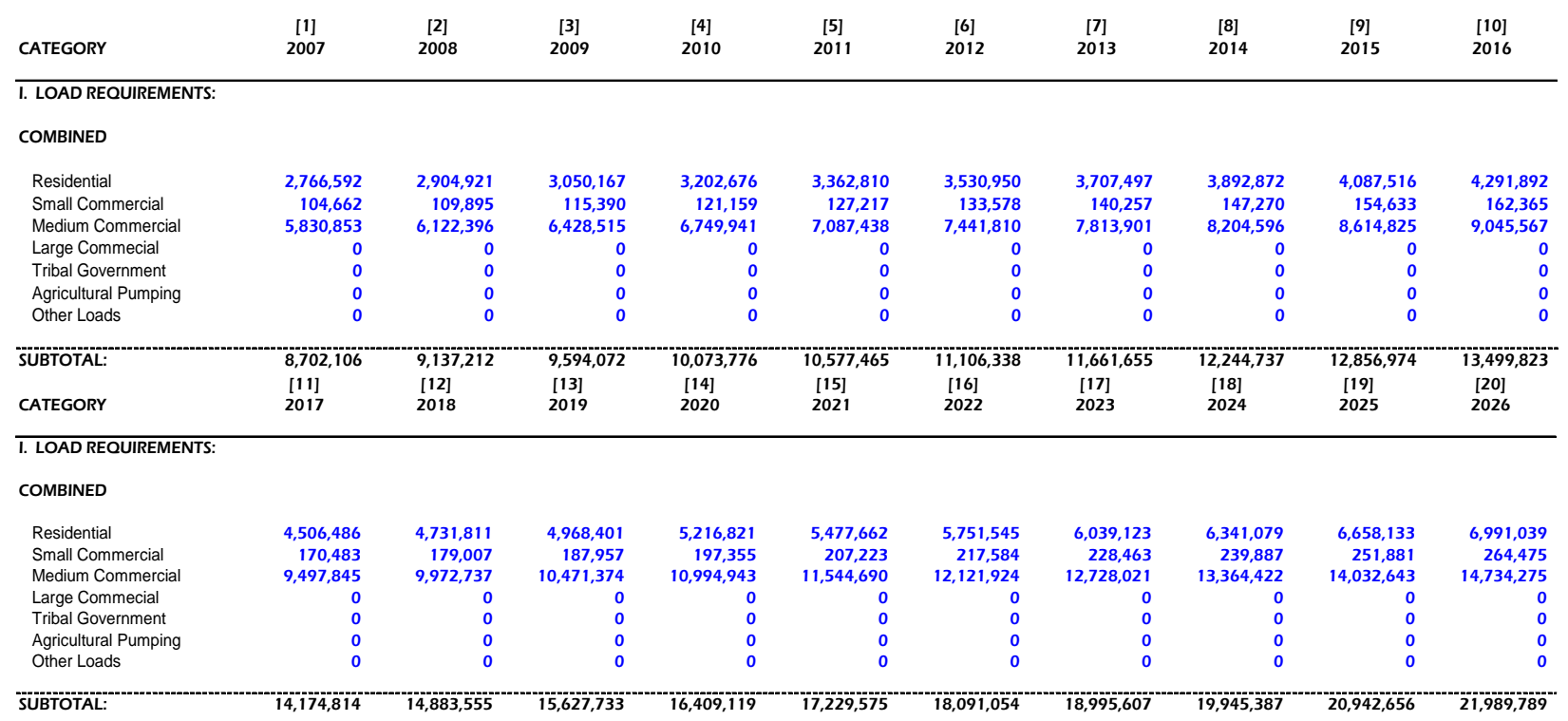

\subsection{WinnaVegas Casino: Facility-Scale Wind Project}

\subsection{Meteorological Tower Installation}

In December 2006, a 50-meter meteorological (met) tower was installed near the WinnaVegas Casino. The met tower collected wind speed data from December 2006 to May 2007 and from January 2008 to 
April 2008. There were numerous issues with the met tower and several months for which there was no data collected. In June 2007, the data logger was struck by lightning and no data was collected between June and December 2007. In addition, the directional vane at 49 meters malfunctioned. In May 2008, the met tower failed again for reasons not yet identified. A new data logger was received and swapped out in November 2008. Figure 3.1-1 summarizes monthly wind speeds collected at WinnaVegas during the months where data was complete. From December 2006 to May 2007, monthly wind speeds varied between 11.9 to $16.1 \mathrm{mph}$. From January 2008 to April 2008, the wind speeds varied from 13.4 to $14.1 \mathrm{mph}$. Figure 3.1-2 displays the directional wind speeds collected from Dec. 2006 through May 2007. The wind speeds are primarily Northwesterly at the WinnaVegas site.

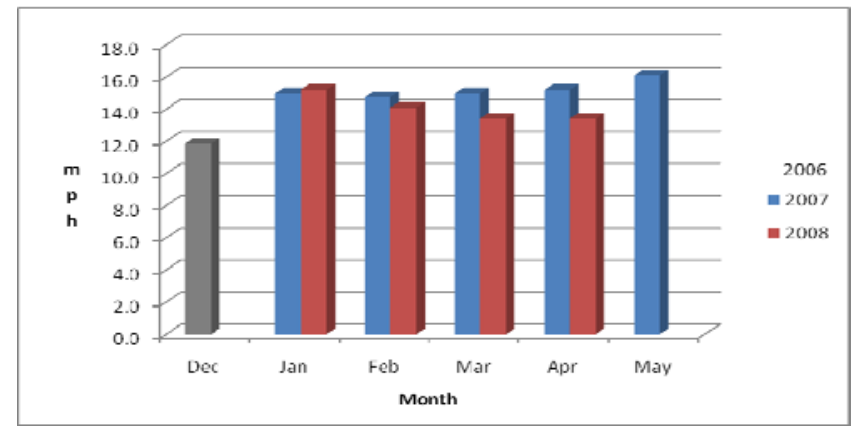

Figure 3.1-1, Monthly Average Wind Speeds at 50 Meters

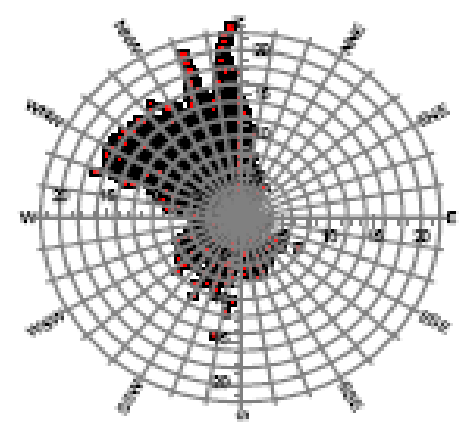

Wind speed [m/s]

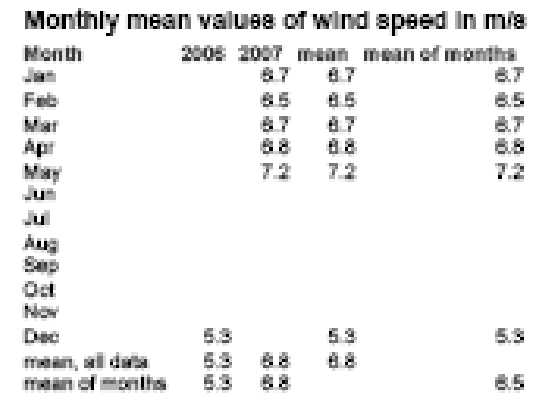

Figure 3.1-2, Directional Wind Speed

\subsection{WinnaVegas Wind Resource Assessment}

In order to conduct a thorough assessment, a minimum of one full year of wind speed data was needed. Unfortunately, due to the technical challenges described previously, this was not possible. There was substantial missing data in both 2007 and 2008. However wind speeds for the missing months were estimated as accurately as possible with the available data.

In estimating the wind speeds for June through November, the shear factor was estimated, which indicates the area terrain and affects of variability of wind speeds at different elevations. The shear factor varied between $0.1-0.2$. The shear factor was then utilized to predict wind speeds at increasing elevations given wind speed at given heights. 
Next, monthly wind speeds were adjusted based on historical wind speeds. The wind speed data was adjusted based on historical wind data available for nearby Sioux City, lowa. Mat lab was utilized to analyze the historic wind data for Sioux City for the following years: 1940, 1945-1951, and 1973-1996, totaling 30 years of data. The annual average wind speeds for Sioux City Airport at 10 meters was estimated at $10.5 \mathrm{mph}(4.7 \mathrm{~m} / \mathrm{s})$. The minimum wind speed was $9.0 \mathrm{mph}$ in August and the maximum was 11.9 mph in April.

The monthly average wind speeds for Sioux City Airport at 10 meters for 2007 were then estimated. This data was compared to the historical monthly average wind speeds to determine if the wind speeds for the areas were "more windy than average" or "less windy than average" and by how much. The 50meter data for 2007 was adjusted according to these estimates.

The annual average wind speed for WinnaVegas was estimated to be $5.9 \mathrm{~m} / \mathrm{s}-6.4 \mathrm{~m} / \mathrm{s}(13.2 \mathrm{mph}-14.3$ $\mathrm{mph}$ ) for shear factors between $0.1-0.2$, reflecting a class 2 to low class 3 wind speed (see Figure 3.41). Figure 3.2-1 illustrates wind class categories at 10 and 50 meters.

\begin{tabular}{|c|c|c|c|c|}
\hline \multicolumn{3}{|c|}{$10 \mathrm{~m}$ (33 ft) } & \multicolumn{2}{|c|}{$50 \mathrm{~m}$ (164ft) } \\
\hline $\begin{array}{l}\text { W/ind } \\
\text { Power } \\
\text { Class }\end{array}$ & $\begin{array}{l}\text { Wind } \\
\text { Power } \\
\text { Density } \\
\left(\mathbf{W} / \mathbf{m}^{2}\right)\end{array}$ & Speed (mph) & $\begin{array}{l}\text { W/ind } \\
\text { Power } \\
\text { Density } \\
\left(\mathbf{W} / \mathbf{m}^{2}\right)\end{array}$ & Speed (mph) \\
\hline 1 & $<100$ & $<9.8$ & $<200$ & $<12.5$ \\
\hline 2 & $100-150$ & $9.8-11.5$ & $200-300$ & $12.5-14.3$ \\
\hline 3 & $150-200$ & $11.5-12.5$ & $300-400$ & $14.3-15.7$ \\
\hline 4 & $200-250$ & $12.5-13.4$ & $400-500$ & $15.7-16.8$ \\
\hline 5 & $250-300$ & $13.4-14.3$ & $500-600$ & $16.8-17.9$ \\
\hline 6 & $300-400$ & $14.3-15.7$ & $600-800$ & $17.9-19.7$ \\
\hline 7 & $>400$ & $>15.7$ & $>800$ & $>19.7$ \\
\hline
\end{tabular}

Figure 3.2-1, Wind Classes at 10 Meters and 50 Meters

\subsection{Monthly Energy Production}

The monthly energy production was estimated utilizing the average monthly wind speed data. The probability density function was utilized to estimate the monthly energy produced at WinnaVegas for a $600 \mathrm{~kW}$ and $1000 \mathrm{~kW}$ wind turbine with annual average wind speeds of $6.185 \mathrm{~m} / \mathrm{s}$ (see Figure 3.3-1). The monthly energy production was compared to energy consumption at the WinnaVegas Casino, based on 2007 electric bills. A $600 \mathrm{~kW}$ wind turbine could provide approximately $30 \%$ of the building's energy load, and a $1000 \mathrm{~kW}$ turbine would provide roughly $44 \%$ of the building's load as illustrated in Figure 3.3-1. 


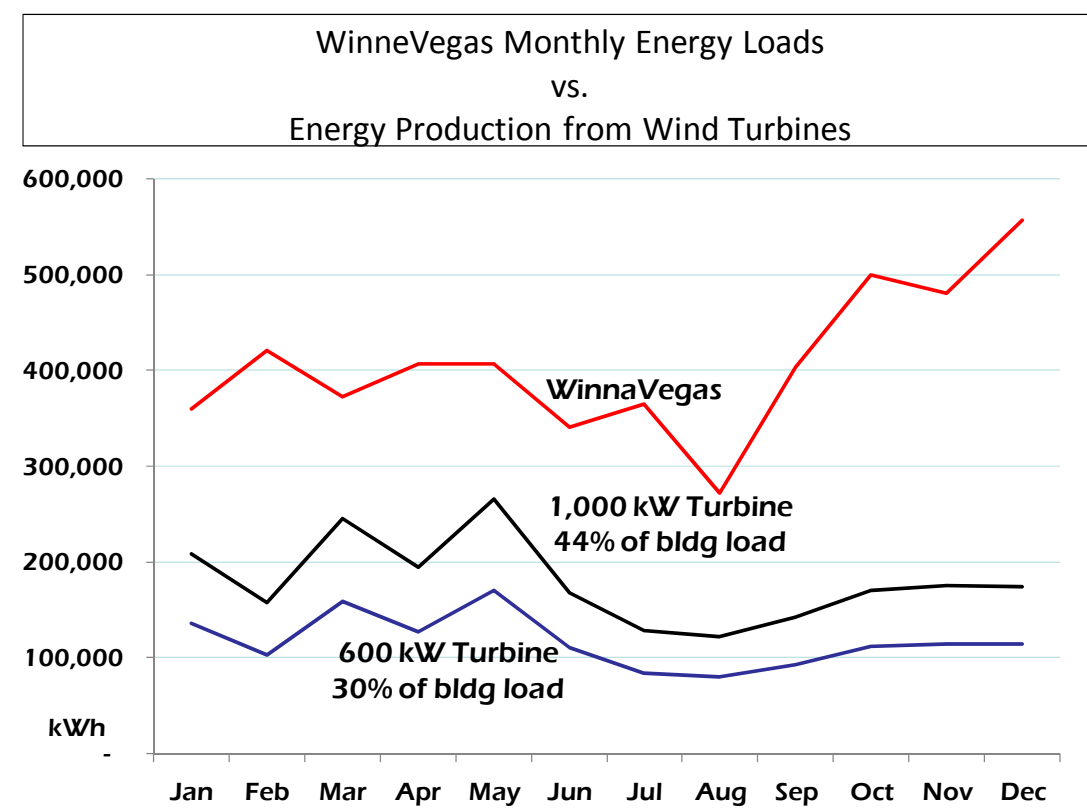

Figure 3.3-1, WinnaVegas Energy Load VS Monthly Energy Production (kWh)

Hourly demand data for WinnaVegas was supplied by Woodbury REC for 6 months in 2007 and for 3 months in 2008 (Figure 3.3-2). Peak energy usage for the casino occurs between 1pm and $10 \mathrm{pm}$, but peak wind energy production occurs between 10am and 3pm. Figure 3.3-3 illustrates average hourly wind speeds based on six months of data.

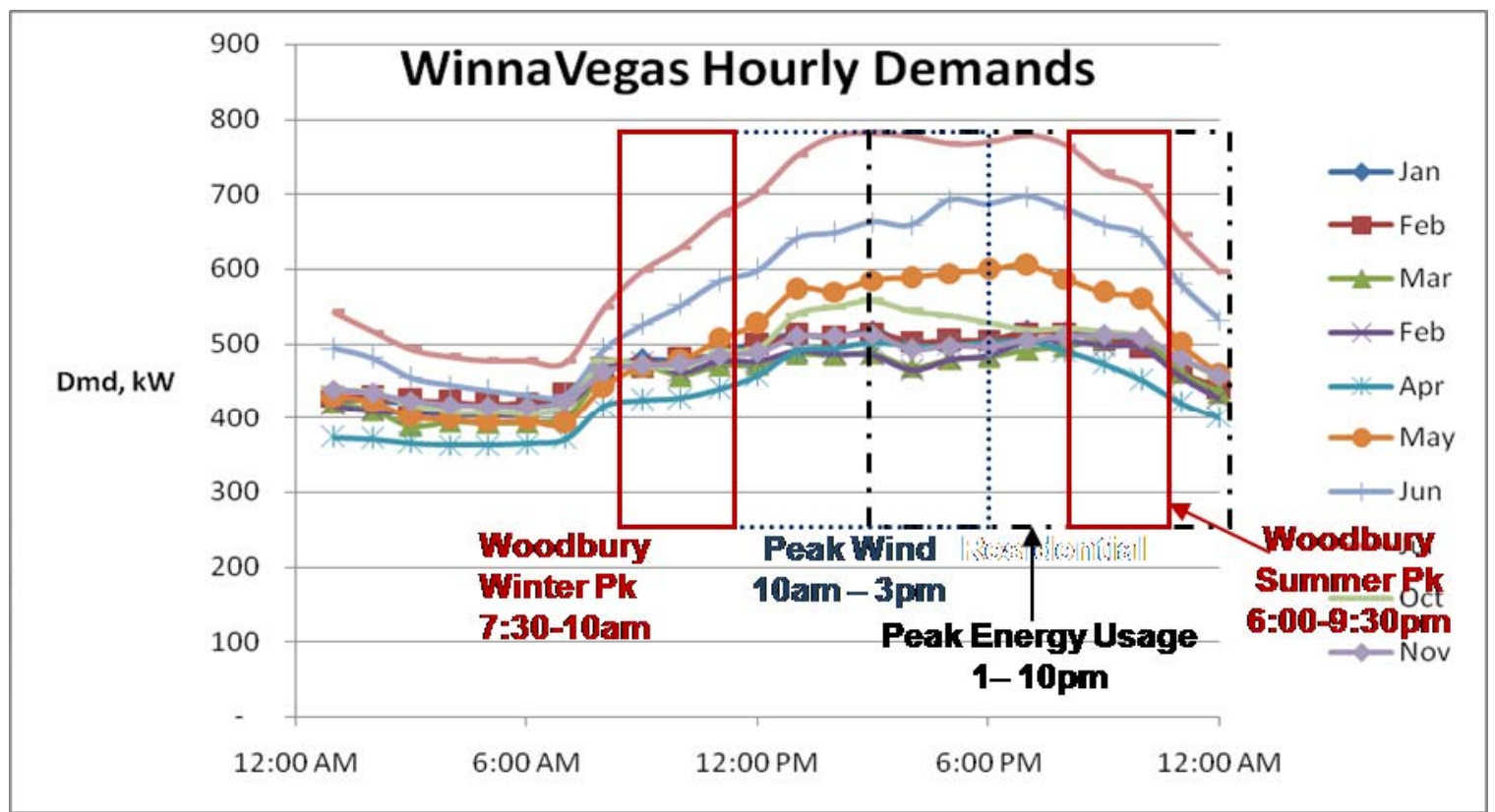

Figure 3.3-2, WinnaVegas Hourly Demands 


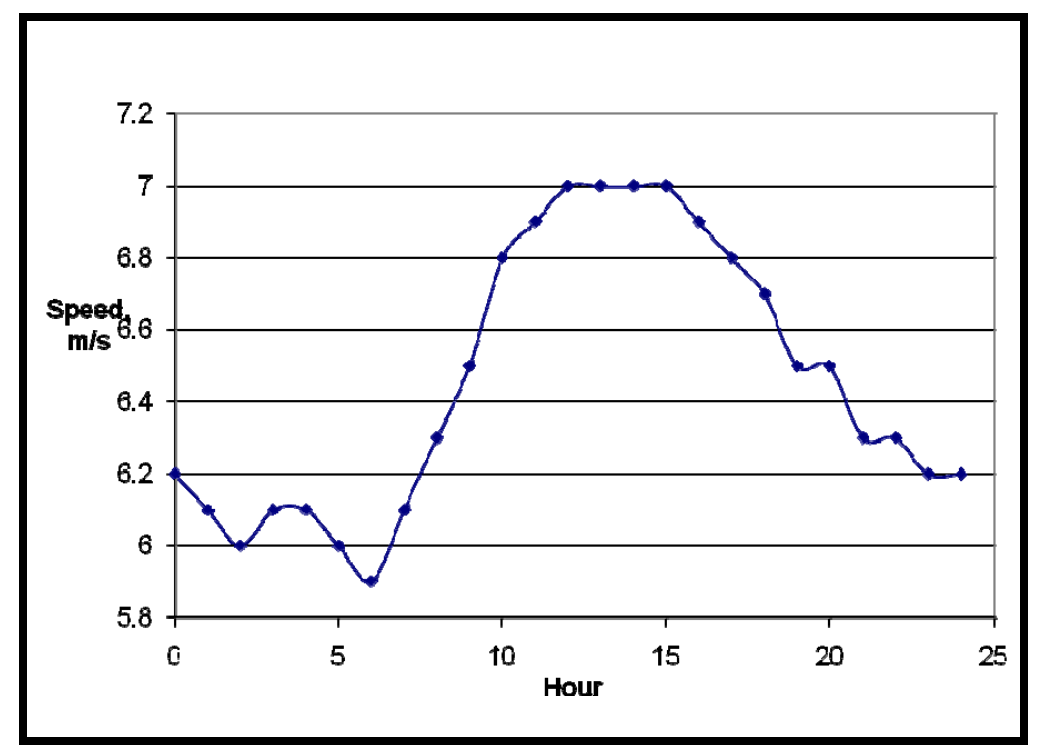

Figure 3.3-3, WinnaVegas Hourly Wind speeds

\subsection{Project Layout and Design}

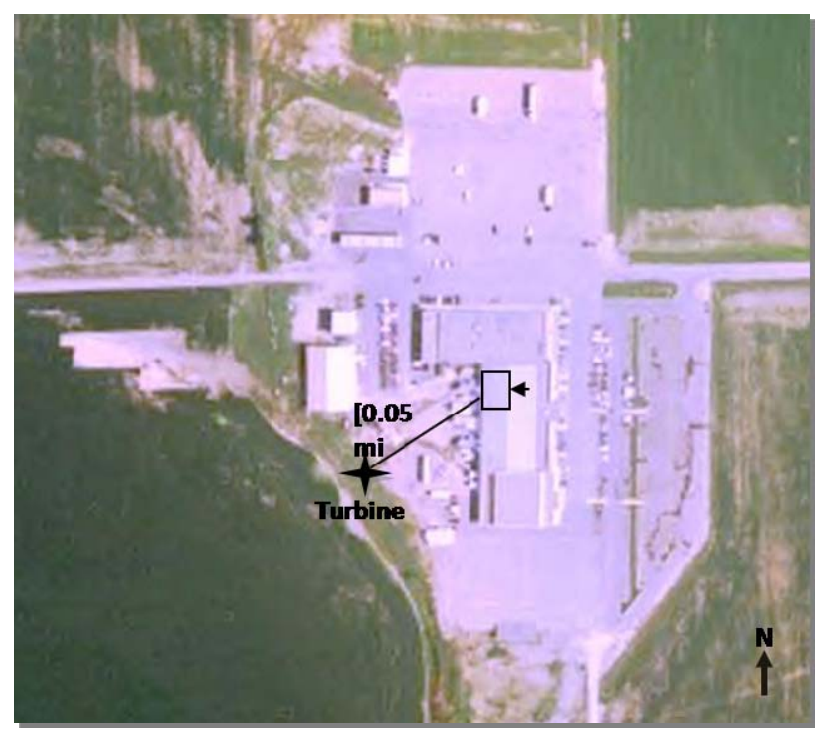

Figure 3.4-1, WinnaVegas Turbine Placement

A preliminary design for a single turbine installation at WinnaVegas is illustrated in Figure 3.4-1. The design goal was to minimize line costs, thus, the turbine was placed as close to the casino as practical and possible. Figure 3.4-1 is a satellite image of the casino with the turbine located close to the casino; it is approximately 264 feet away from the building and near the underground $12.5 \mathrm{kV}$ electric distribution line. Figure 3.4-2 is a breakdown of site specifications. 


\begin{tabular}{|l|l|}
\hline Building & \\
\hline Description: & WinnaVegas Casino, Stoan, IA \\
\hline Max Building Height: & $18 \mathrm{ft}$ \\
\hline Voltage: & 3 phase 277/480 V \\
\hline Line Voltage: & $12.5 \mathrm{kV}$ (Underground) \\
\hline Utility Transformer: & $1500 \mathrm{kVA}$ \\
\hline Metering: & Primary \\
\hline Turbine \& Wind & \\
\hline Approximate location: & $\begin{array}{l}42.233 \mathrm{~N} 96.317 W \\
\text { approximately 0.05 mi (264 ft) }\end{array}$ \\
\hline Distance from electric room: & Primarily Northwesterty \\
\hline Wind direction: &
\end{tabular}

Figure 3.4-2, WinnaVegas Electrical Specifications

Figure 3.4-3 is a one-line diagram of the interconnection supplied by Genentech for their $750 \mathrm{~kW}$ turbine. The actual design would depend on turbine selection and negotiations with Woodbury REC on interconnection arrangements.

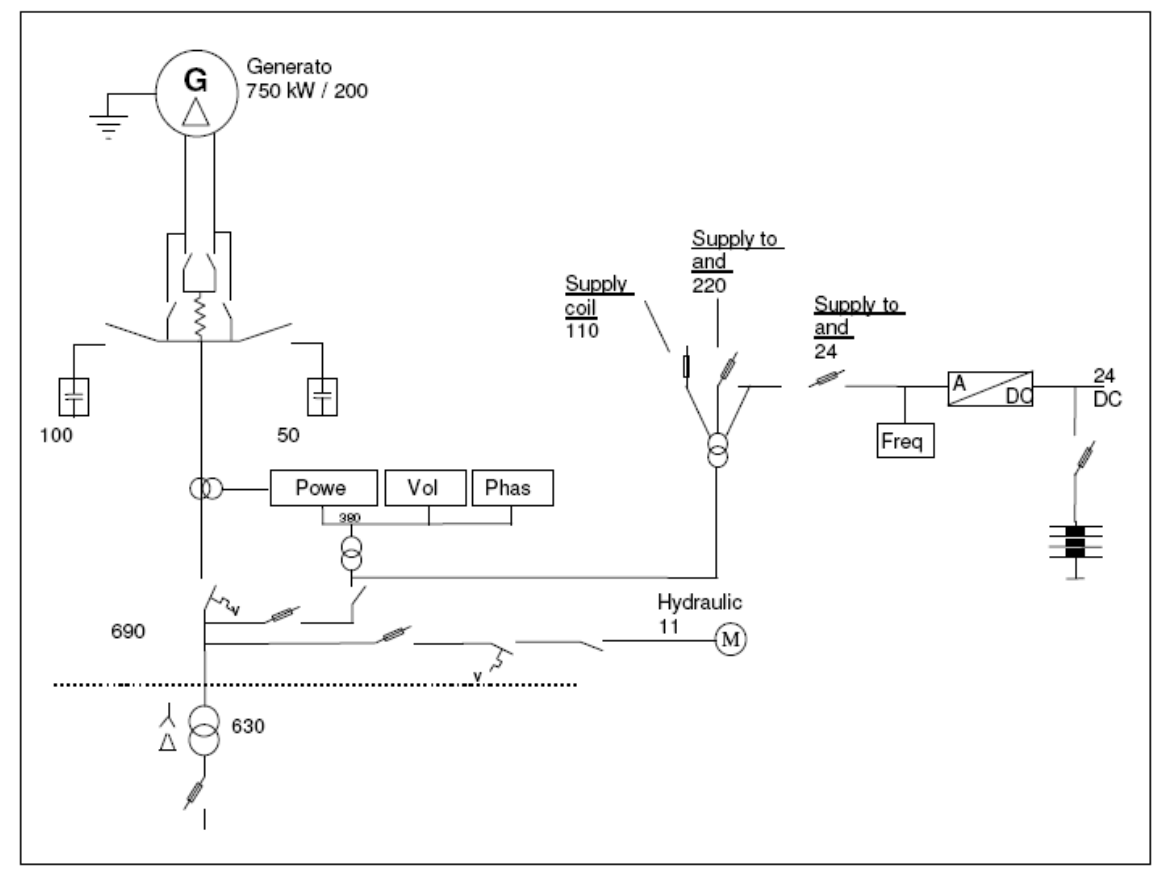

Figure 3.4-3, Turbine Interconnection Line Diagram

\subsection{Turbine Costs}

The following compares two facility-scale wind turbines that were identified to meet less than $50 \%$ of the energy demand for the WinnaVegas casino. The two turbines are not necessarily the technologies 
of choice; the main purpose for this analysis was to compare the difference in hardware, design and power costs.

Costs were estimated for facility scale wind turbines: $600 \mathrm{~kW}$ and $750 \mathrm{~kW}$ as shown below in Figure 3.5-1. The Vestas N47 $600 \mathrm{~kW}$ unit is distributed by Blue Sky Wind in White Plains, NY and has a current lead time of eight months. The Genentech E50 $750 \mathrm{~kW}$, manufactured and distributed by Genentech, has a current lead time of 12-14 months. A comparison of the costs of these two turbines is provided in Figure 3.5-2. The cost break down in Figure 3.6-3 includes: engineering, balance of plant, and miscellaneous costs. Turbine, design, and installation costs were provided by turbine dealers and installers. These costs were further broken down using Retscreen wind analysis tools that provide approximate percentages of total cost for each item.

\begin{tabular}{|c|c|c|}
\hline Initial Costs (Credits) & $600 \mathrm{~kW}$ & $750 \mathrm{~kW}$ \\
\hline \multicolumn{3}{|l|}{ Energy Equipment } \\
\hline Whd turbine(s) & $1,090,000$ & $1,100,000$ \\
\hline Spare parts & 21,800 & 22,000 \\
\hline Sub-total: & $1,111,800$ & $1,122,000$ \\
\hline Initial Costs (Credits) & $600 \mathrm{~kW}$ & $750 \mathrm{~kW}$ \\
\hline \multicolumn{3}{|l|}{ Engineering } \\
\hline Mechanicaldesign & $\$ \quad 48,000$ & 48,000 \\
\hline Electrical design & 48,000 & 48,000 \\
\hline Civi design & 16,000 & 16,000 \\
\hline Tenders and contracting & 12,000 & 12,000 \\
\hline Construction supervision & 66,000 & 66,000 \\
\hline Sub-total: & 190,000 & 190,000 \\
\hline
\end{tabular}

\begin{tabular}{|c|c|c|}
\hline Initial Costs (Credits) & $600 \mathrm{~kW}$ & $750 \mathrm{~kW}$ \\
\hline \multicolumn{3}{|l|}{ Balance of Plant } \\
\hline Whd turbine(s) foundation(s) & 100,000 & 100,000 \\
\hline Whd turbine(s) erection & 100,000 & 100,000 \\
\hline Transmission [ne \& Interconnect & 225,000 & 225,000 \\
\hline Sub-total: & 425,000 & 425,000 \\
\hline \multicolumn{3}{|l|}{ Miscelaneous } \\
\hline Training & 8,000 & 8,000 \\
\hline Commissioning & 15,000 & 15,000 \\
\hline Contingencies & 18,026 & 18,138 \\
\hline Interest during construction & 81,926 & 82,436 \\
\hline Sub-total: & 122,952 & $12 \mathbf{1 2 3 , 5 7 4}$ \\
\hline Initial Costs - Total & $\$ 1,849,752$ & $\$ 1,849,206$ \\
\hline
\end{tabular}

Figure 3.5-1, WinnaVegas Wind Turbine Costs 
Figure 3.5-1 summarized all costs for the $750 \mathrm{~kW}$ energy system that are utilized to estimate the levelized cost of energy (LCOE) in dollars per kWh. The total installed cost for the system is in the higher range of costs, compared with Figure 3.5-2, which shows the trend for wind system costs in the US. The majority of the data reflects costs from wind farms. As system sizes decrease, the cost per $\mathrm{kW}$ and $\mathrm{kWh}$ increases.

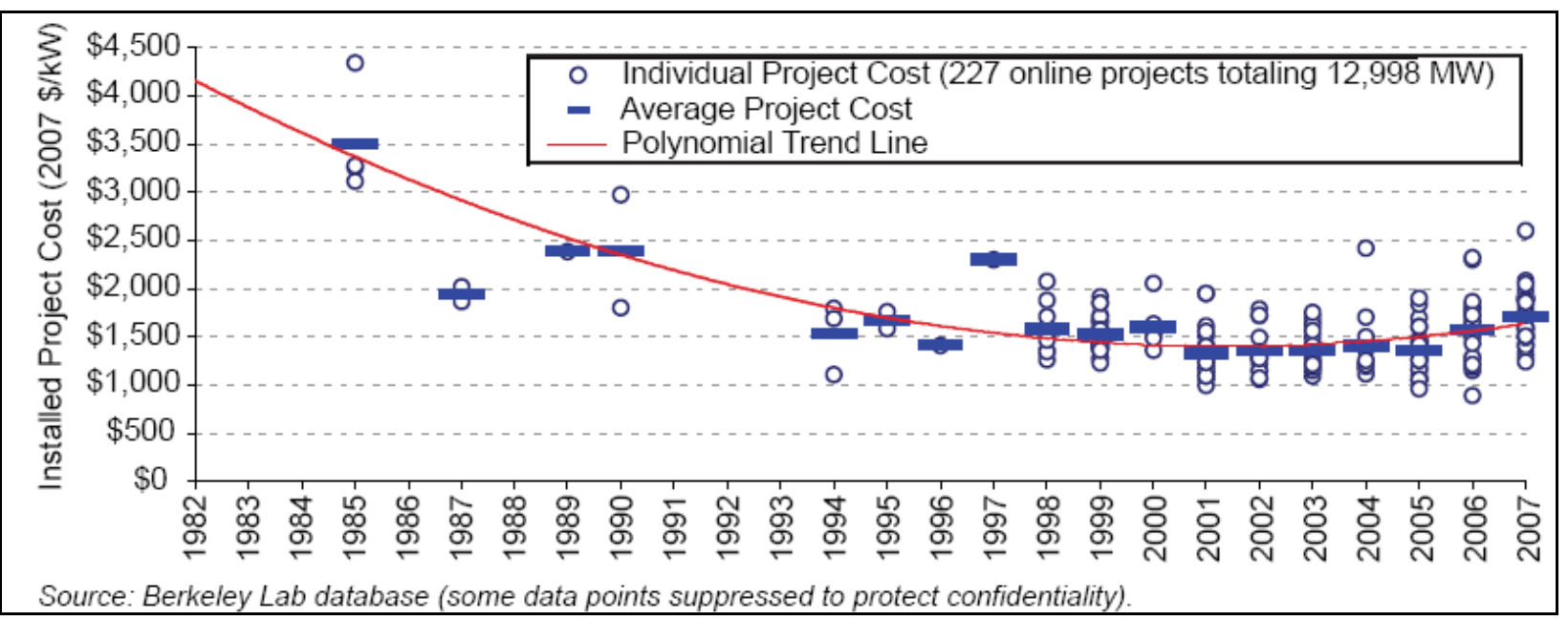

Figure 3.5-2 Wind System Costs

The primary difference in cost between the two units is in turbine costs. Both units include delivery and a $65 \mathrm{~m}$ tubular tower. Spare part costs were estimated at $2 \%$ of the turbine cost. Engineering, installation and balance of plant costs were provided by Free Breeze Energy Systems, Ontario, CA. Total costs for these items were estimated to be in the range of $\$ 600,000-\$ 800,000$ for the site identified in Figure 3.5-1. The total cost for system design, installation and equipment will be between $\$ 1.8$ - \$2.1 million, respectively for $600 \mathrm{~kW}$ and $750 \mathrm{~kW}$ systems. Engineering design costs are typically between $10-15 \%$ of the total costs for a facility scale project, and were estimated at $\$ 190,000$. Designs include:

- Mechanical design and planning of the assembly and erection of equipment

- Electrical design of the controls, electrical protection systems and electrical interconnection with the existing electrical grid

- Civil design of constructing foundations, access roads and other ground systems. The level of effort will depend on availability of site specific information such as access, soil conditions, surface drainage, and other conditions

Costs for foundation and erection were both estimated at $\$ 100,000$ each. The wind turbine erection includes labor and equipment rental such as cranes, winches, gin poles, etc. See the Appendix for crane rental quote from a local supplier for the $600 \mathrm{~kW}$ units. The current wait time for cranes is in the 2 year range. Transmission and interconnection costs depend on type, length, voltage, line location, and size of the wind turbine, and can vary between $9-14 \%$ of the total costs. Miscellaneous costs include training, commissioning, contingencies, and interest. A 1\% contingency was included in the estimates. Interest during construction will vary depending on the duration of construction and interest rates. 


\subsection{Levelized Cost of Energy}

The calculation utilized to determine the cost of energy for the WinnaVegas wind turbine system is as follows:

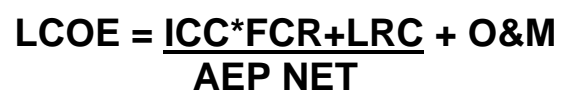

- $\quad$ AEPNET $=$ AEPGROSS * Availability * (1 - Loss)

- $\quad \mathrm{COE}=$ Cost of Energy $(\$ / \mathrm{kWh})$

- $\quad$ ICC = Initial Capital Cost (\$)

- FCR= Fixed Charge Rate (\%/year)

- $\quad$ LRC= Levelized Replacement Cost (\$/year)

- $O \& M=$ Operations and Maintenance Costs (\$/kWh)

- $\quad A E P=$ Annual Energy Production (kWh/year)

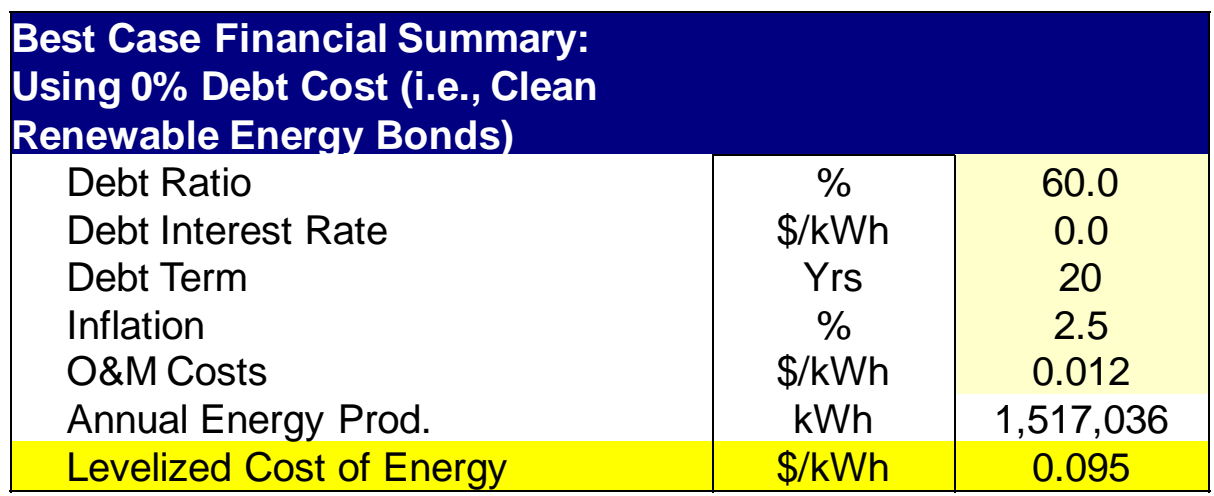

Low Debt Cost (3\%: USDA Financing) Leveled Cost of Energy - \$0.107/kWh Moderate Debt Cost (6\% Financing) Levelized Cost of Energy - \$0.120/kWh

Figure 3.6-1, WinnaVegas Wind Project Financial Summary

The case resulting in the lowest cost of energy assumed use of Clean Renewable Energy Bonds (CREBs) for financing at zero percent interest as illustrated in Figure 3.6-1. Cases run using either lowcost debt or moderate-cost debt would result in even higher costs of energy.

\subsection{Woodbury County Rural Electric Cooperative On-Site Generation}

Preliminary discussions with Woodbury County REC regarding onsite generation of power for the WinnaVegas Casino revealed two possible options for onsite power generation and sales on their lines.

Woodbury REC does not offer net metering, but has a Tariff for Standby Service that would supplement power generated by the wind turbine. See the Appendix for the tariff. Under this agreement, generation capacity is set aside and this set aside of capacity is deemed the emergency power supply when the turbine is not generating. The charge for this capacity and service consists of four parts: coincidental kW, non-coincidental kW, kWh and customer charge. The coincidental kW and noncoincidental kW charges total $\$ 19 / \mathrm{kWp}$ per month. For a $750 \mathrm{~kW}$ turbine, a charge of $\$ 14,250 /$ month 
would apply. This charge is higher than the value of power generated by the turbine at $\$ 0.06 / \mathrm{kWh}$, thus making this scenario extremely unattractive.

If WinnaVegas wished to sell all of the capacity and energy to Northern lowa Power Company (NIPCO), it would be treated as a source substation for Woodbury REC. Standby Service is not required because all of the casino electricity requirements would be taken from Woodbury REC under the current Large Power Contracts rate, and the wind generation would be sold to NIPCO. An agreement between the casino and NIPCO for the purchase of the wind power would be required. There is no capacity payment under this rate and the energy payment rate is $\$ 0.044$ per $\mathrm{kWh}$ for output delivered to NIPCO subject to the reduction per Eligibility Criteria, Section 4. This rate is committed through 2008 and includes REC sales as well. For periods committed to beyond 2008, the Base Load Resource payment rates shall be escalated at $1.5 \%$ per year. For a $750 \mathrm{~kW}$ turbine generating approximately $1,550 \mathrm{MWh}$ annually, at $\$ 0.044 / \mathrm{kWh}$, this equates to $\$ 68,200$ in power sales to NIPCO. This scenario was not attractive either. Both are summarized in Figure 3.7-1.

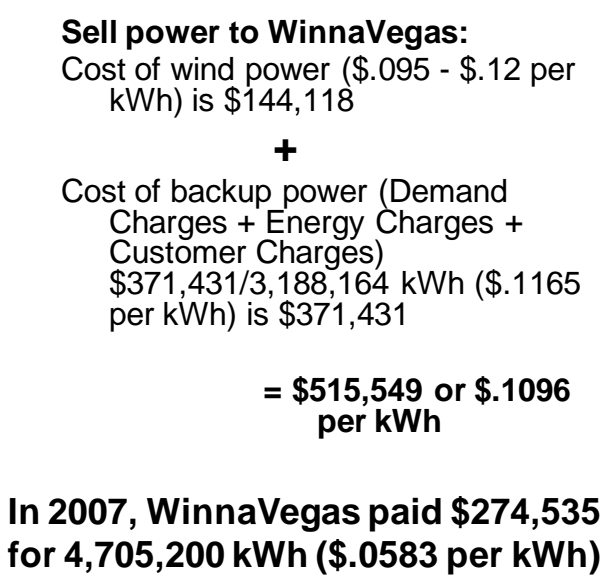

\section{Sell power to NIPCO:}

NIPCO willing to pay only avoided cost rate of $\$ .044$ per $\mathrm{kWh}$

Cost to generate wind power is $\$ .095-\$ .12$ per kWh

Figure 3.7-1, Summary of WinnaVegas Options

\subsection{Energy Audit}

Energy audits were conducted on two major facilities: the Blackhawk Community Center and the WinnaVegas Casino. Both electric providers offer complimentary energy audits to all residential and commercial customers. Summary reports for both audits are available in the Appendix.

WinnaVegas Casino had previously implemented numerous energy efficiency improvements. These included major improvements to the heating, ventilating, and cooling system. The large air-handling units for the casino were converted from $100 \%$ outdoor air to a return air system. Heat recovery wheels and demand-controlled ventilation are used in all major heating and cooling units. Much of the fluorescent lighting had been upgraded to high efficiency F32T8 systems. A comprehensive direct digital control / energy management system by American Auto-Matrix has been installed and is used extensively by staff. Finally, the energy management system is well managed and maintained by facilities staff.

The following energy efficiency opportunities were found: 
- Lighting improvements

- Kitchen hood controls

- Low flow sprayers

- Use of electric supplemental heat

Further energy calculations were estimated to determine cost and energy savings associated with each opportunity. Figure 3.8-1 summarizes the energy savings in gallons, kWhs, and dollars. In addition, technology costs, simple payback and incremental electric usage are also estimated in the table. The average cost per gallon of propane used in the analysis was $\$ 1.55$. Replacing existing kitchen sprayers with "low flow" sprayers would cost $\$ 300$, however, it will save WinnaVegas $\$ 792$ annually; thus the simple payback for this replacement is 0.4 years.

Utilizing electricity to provide supplementary heat to replace current propane heat will cost $\$ 18,000$. However, annual energy savings will be $\$ 6,486$ and have a simple payback of 2.8 years. Variable frequency drive (VFD) hoods are also recommended in the kitchen. Current hoods operate at a constant speed all day long whereas VFD hoods operate at controlled speeds relative to the usage. VFD hoods cost $\$ 8,940$ and can save $\$ 1,559$ annually; the simple payback would be 5.7 years. Replacing exit signs would cost $\$ 150$ and will save $\$ 88$ annually and have a simple payback of 1.7 years. Replacing all incandescent lighting with compact fluorescent (CFL) will cost $\$ 4,950$, but will save $\$ 4,013$ annually and have a simple payback of 1.2 years. Finally, replacing T-12 with T-8 lighting will cost $\$ 5,897$ and will save $\$ 781$ annually; thus the simple payback is 7.6 years. These calculations are based on current energy prices and do not take into consideration increases in future years.

\begin{tabular}{|c|c|c|c|c|c|c|}
\hline & $\begin{array}{c}\text { Savings } \\
\text { (gal) }\end{array}$ & $\begin{array}{c}\text { Savings } \\
\text { (kWh) }\end{array}$ & $\begin{array}{c}\text { Savings } \\
\$\end{array}$ & $\begin{array}{c}\text { Cost } \\
5\end{array}$ & $\begin{array}{c}\text { Simple } \\
\text { Payback } \\
\text { Yrs }\end{array}$ & $\begin{array}{l}\text { Inc } \\
\text { Elec, } \\
\text { kWh }\end{array}$ \\
\hline Low flow sprayers & 511 & 511 & $\$ 792$ & $\$ 300$ & 0.4 & \\
\hline Elec Supp Heat & 6,242 & 6,242 & 6,486 & 18,000 & 28 & 87,360 \\
\hline VFD in kitch hood & 755 & 10,656 & 1,559 & 8,940 & 57 & \\
\hline Exit Signs & & 2,418 & 88 & 150 & 1.7 & \\
\hline CFL & & 109,958 & 4,013 & 4,950 & 1.2 & \\
\hline T-8 lighting & & 19,870 & 781 & 5,897 & 7.6 & \\
\hline TOTAL & 7,508 & 149,655 & $\$ 13,720$ & $\$ 38,237$ & & \\
\hline
\end{tabular}

Figure 3.8-1, WinnaVegas Energy Savings Summary

Envelope improvements were not considered for the following reasons. First, the casino has already added insulation where possible in the casino area. Second, due to the large amount of people, slot machines, and lights in the casino area, a significant amount of heat is generated internally. Much of the energy used for heating is actually for conditioning outside air for ventilation, and not for envelope heat losses. Additional insulation should be considered when a new roof is contemplated over the bingo hall. Additional insulation could be installed between the roof deck and the roof membrane at that time. 
Alternative lighting options were considered in the higher ceiling section of the bingo. This area has dimmable compact fluorescent fixtures. A quick calculation revealed that replacing one fixture with three lamp troffers with similar overall lumens would only save a small amount of energy.

There have been significant improvements in the cooling efficiency of packaged rooftop mounted equipment. When the existing heating, ventilating, and air-conditioning (HVAC) equipment is in need of replacement, a more efficient system is highly recommended. Simple paybacks for these systems are typically between 5 and 7 years.

\subsection{Energy Demand Management}

Opportunities for cost savings through demand management were also explored. Energy demand management, also known as demand response or load shedding, would entail managing consumer energy usage in response to supply conditions. Peak demand management would not necessarily decrease total energy consumption but would reduce peak utility demand. Electricity consumption from services such as lights, machines, air conditioning, etc. would be reduced according to a preplanned load prioritization scheme during the critical timeframes. An alternative to load shedding would be onsite generation of electricity to supplement the power grid. Under conditions of tight electricity supply, demand response could significantly reduce the peak price and, in general, electricity price volatility.

Utilities offer incentives for demand management, or charge higher rates for energy consumed during peak times. The Woodbury County REC offers a demand response program for heating cooling and ventilation systems (HVAC). This program regulates heating and cooling temperatures during peak times. In the winter time, peak periods for Woodbury are at approximately 7:30 AM; in the summer time, peak periods are in the 6 to 6:30 PM time frame. When demand management is implemented, controls or reductions would begin before the peak time and would end several hours after the peak has occurred.

However, this scenario of controlling heating and cooling temperatures during peak hours may not be attractive to a business such as WinnaVegas where customer comfort may be impacted. While a demand response program that is available from Woodbury REC may result in energy cost savings, it could affect customer satisfaction. Also, according to WinnaVegas energy records, no rate difference between the demand rate and the peak demand rate exists. Demand management controls that decrease peak loads would not result in any additional cost savings, and were not recommended for WinnaVegas. 


\subsection{Large Scale Wind Project Evaluations}

\subsection{Interconnection Options}

There are seven substations within and around Winnebago, four of which are near potential wind development sites. These four substations are owned by the following utilities:

- Nebraska Public Power District (NPPD)

- $\quad$ Northeast Nebraska Public Power District (NNPPD)

- Burt County Public Power District (BCPPD)

- Butler Public Power District (BPPD)

Another potential interconnection option is with the Omaha Public Power District (OPPD). OPPD has transmission lines near the Thunderway site. Even though OPPD does not have any substations nearby, a large wind project could consider interconnecting with OPPD lines.

NPPD's transmission network involves facilities energized at $115 \mathrm{kV}$ or higher and operated as an interconnected electrical system. The NPPD transmission system is operated as a part of the Eastern Interconnected electrical network which spans a large portion of the Midwest and the entire eastern portion of the United States and is the largest interconnected grid in North America. NPPD is a member of the Midwest Reliability Organization (MRO) which is NPPD's Regional Reliability Organization (RRO). NPPD is a member of the Mid-Continent Area Power Pool (MAPP) Regional Transmission Committee (RTC) that is NPPD's Planning Authority. The MAPP region encompasses all or parts of seven upper Midwest states and two Canadian Provinces. The MRO Region encompasses the MAPP region plus several former members of the MAIN reliability council.

NPPD's sub-transmission facilities are operated at $34.5 \mathrm{kV}-69 \mathrm{kV}$ and function as a radial power delivery system to provide for wholesale power deliveries to firm network service load customers. These customers are typically rural public power districts, municipal systems or large retail cities and towns. Figure 4.1-1 illustrates the regional transmission system on the Winnebago reservation and surrounding area. 


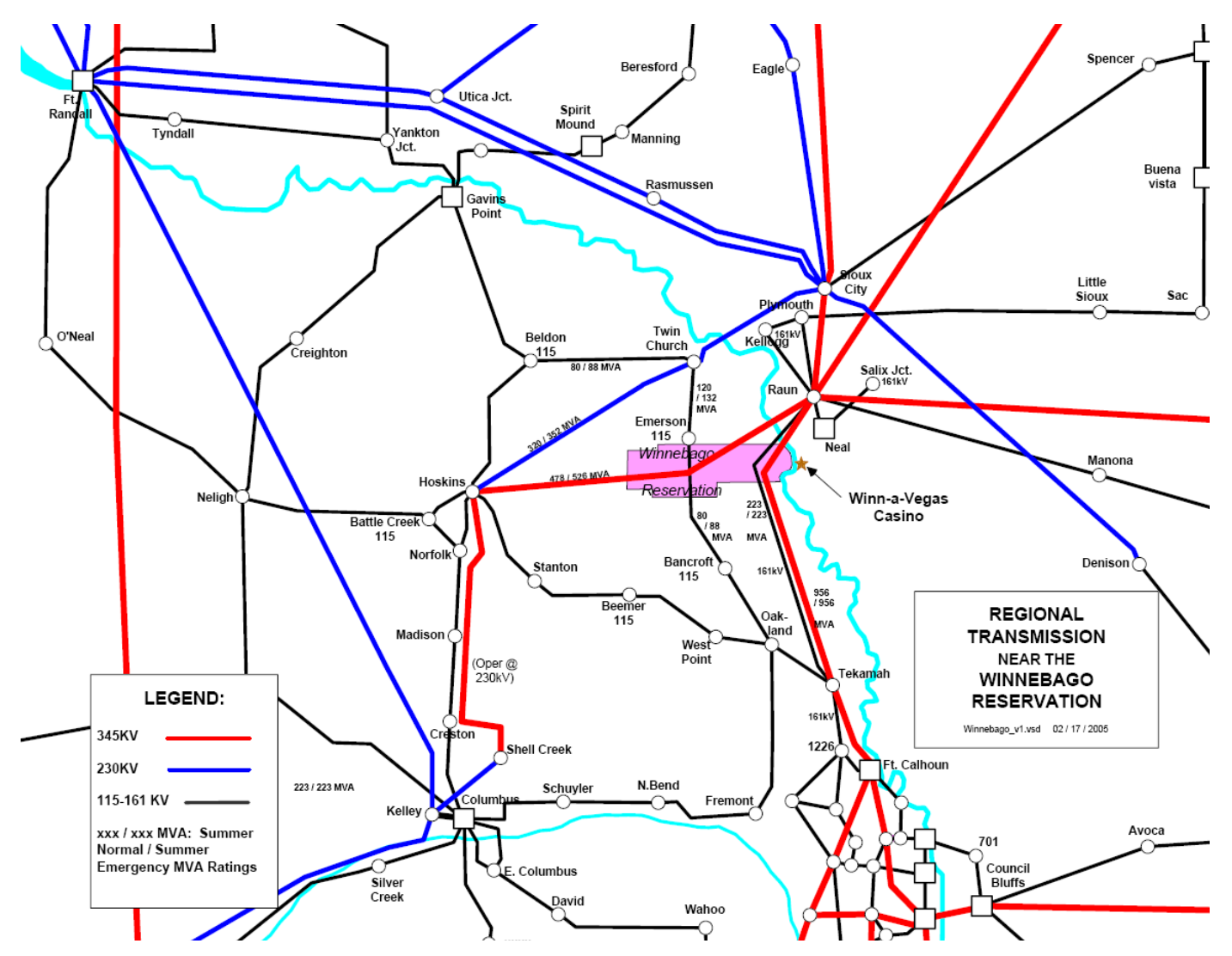

Figure 4.1-1, Regional Transmission Map

NPPD is the power generator for both BCPPD and NNPPD. BPPD and NNPPD are members of the Nebraska Rural Electric Association. ${ }^{1}$ The association of cooperatives supports an initiative that seeks to voluntarily reach a goal of having $25 \%$ renewables by 2025 in addition to reducing Greenhouse Gas emissions by $18 \%$ over a 10 -year period. NNPPD does not generate any electricity.

NPPD currently has a goal to achieve 10 percent of its energy supply from renewable resources by 2020 and planned to install meteorological (met) towers at 10 locations throughout the state by the end of 2008. NPPD has invested more than $\$ 80$ million in wind generation throughout Nebraska since 1995 and owns and operates the state's largest wind facility near Ainsworth, a $60 \mathrm{MW}$ facility with 36 wind turbines. Omaha Public Power District, Jacksonville Electric Authority, Municipal Energy Agency of Nebraska, and the City of Grand Island purchase energy from the facility. In addition to the $60 \mathrm{MW}$ Ainsworth wind project, an $80 \mathrm{MW}$ project is being constructed north of Bloomfield, and NPPD signed a 20-year power purchase agreement with Midwest Wind Energy, LLC and its affiliate Elkhorn Ridge Wind, LLC, for a $42 \mathrm{MW}$ wind project being constructed in Crofton Hills. Community Wind Energy Transmission, LLC, will operate and manage the Crofton Hills facility.

\footnotetext{
${ }^{1}$ Nebraska Rural Electric Association, http://www.nrea.org/systems/, November 2008.
} 


\begin{tabular}{|c|c|c|}
\hline & OPPD & NPPD \\
\hline Avolded Rates, centsikwh & 2.6 & $2-3$ \\
\hline Renewrable raals & $100 \mathrm{MW}$ by 2015 & $10 \%$ by 2020 \\
\hline Wind & $10 \mathrm{MW}$ & $60 \mathrm{MW}$ \\
\hline Wnd RoPs & $100 \mathrm{MW}$ by 2015 & $150 \mathrm{MW}$ by 2000 \\
\hline Wind Investreants & 50 & $580 \mathrm{M}$ \\
\hline Poner Cenernting Capecty & $2,659.9 \mathrm{MW}$ & $2,804.5 \mathrm{MW}$ \\
\hline
\end{tabular}

Figure 4.1-2, OPPD Versus NPPD Renewable Goals

Figure 4.1-2 compares OPPD and NPPD wind and renewable goals, rates, investments and total power generating capacities. NPPD has more aggressive goals for wind power generation. NPPD has $60 \mathrm{MW}$ of wind power generation, $10 \mathrm{MW}$ of which is sold to OPPD. NPPD intends to procure $150 \mathrm{MW}$ of wind from projects on its system by 2009 while OPPD intends to install $100 \mathrm{MW}$ by 2015. NPPD will exceed its goal of $150 \mathrm{MW}$ and will have $180 \mathrm{MW}$ installed by 2009 .

Figure 4.1-2 summarizes NPPD's sources of power supply as of 2006.

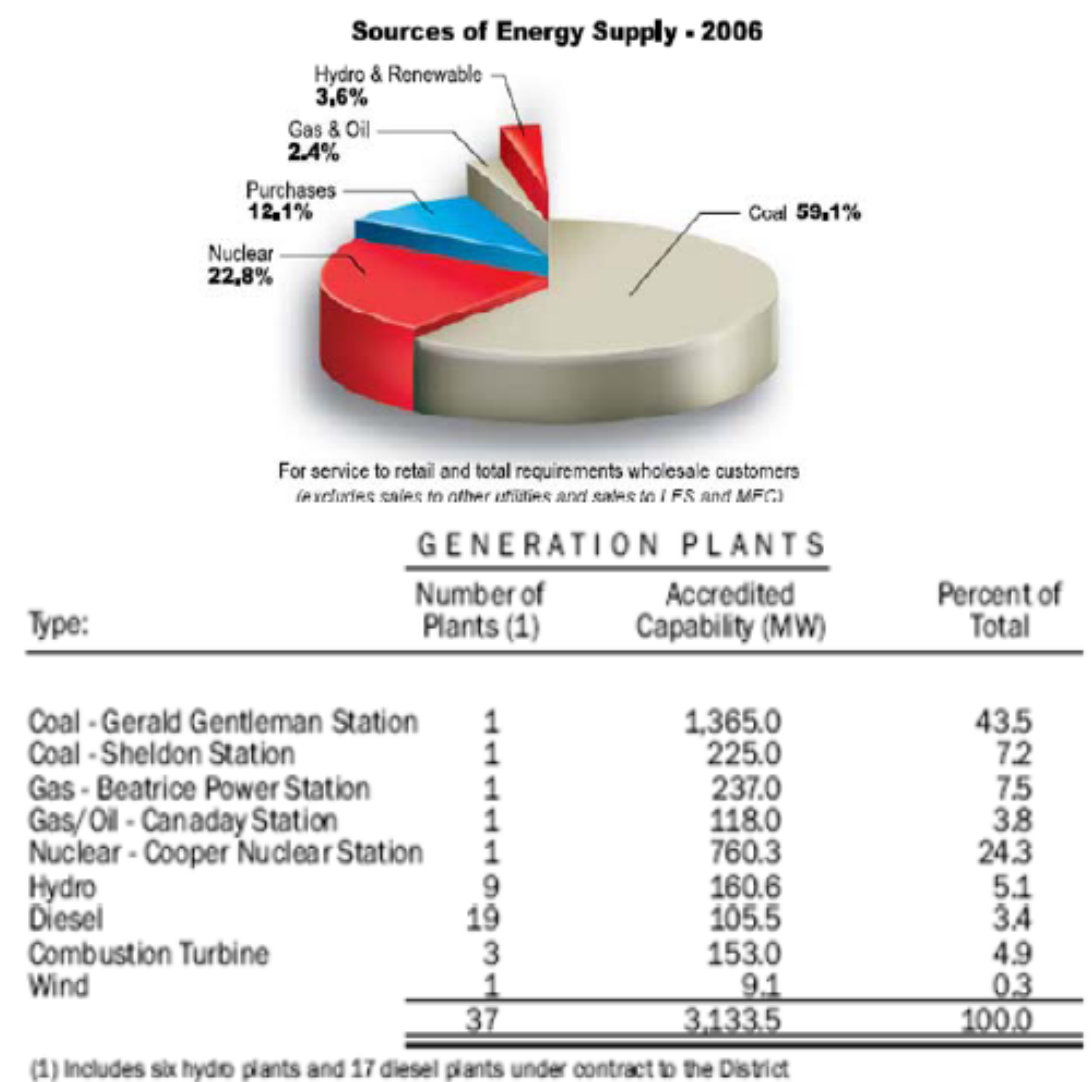

Figure 4.1.3 NPPD Power Supply Sources 


\subsection{Western Winnebago: Utility-Scale Wind Project Site}

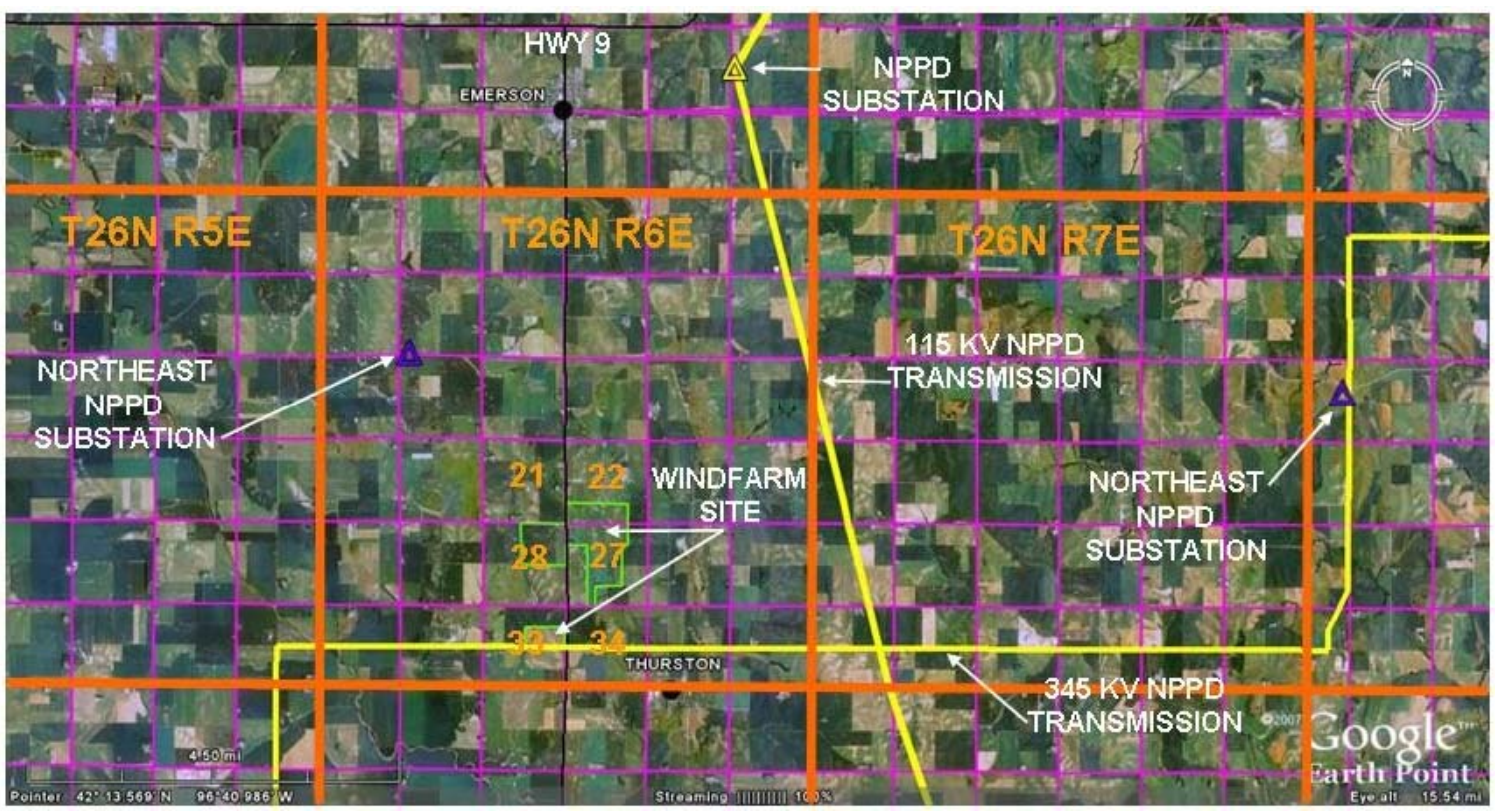

Figure 4.2-1, Western Winnebago Site

The Western Winnebago Site is the primary commercial-scale project site for Winnebago (see Figure 4.2-1). The Western Winnebago Site is located within sections 22, 27, 28, and 33 of the township and range T26N R6E within the Nebraska State PLSS system (Public Land Survey System, NAD 83). The proposed windfarm project area is comprised of three main non-contiguous trust land areas totaling approximately 631 acres. The project location in Sections 22 and 27 total 405 acres in area. The project area located in Section 28 totals 151 acres. The project area located in Section 33 totals 75 acres.

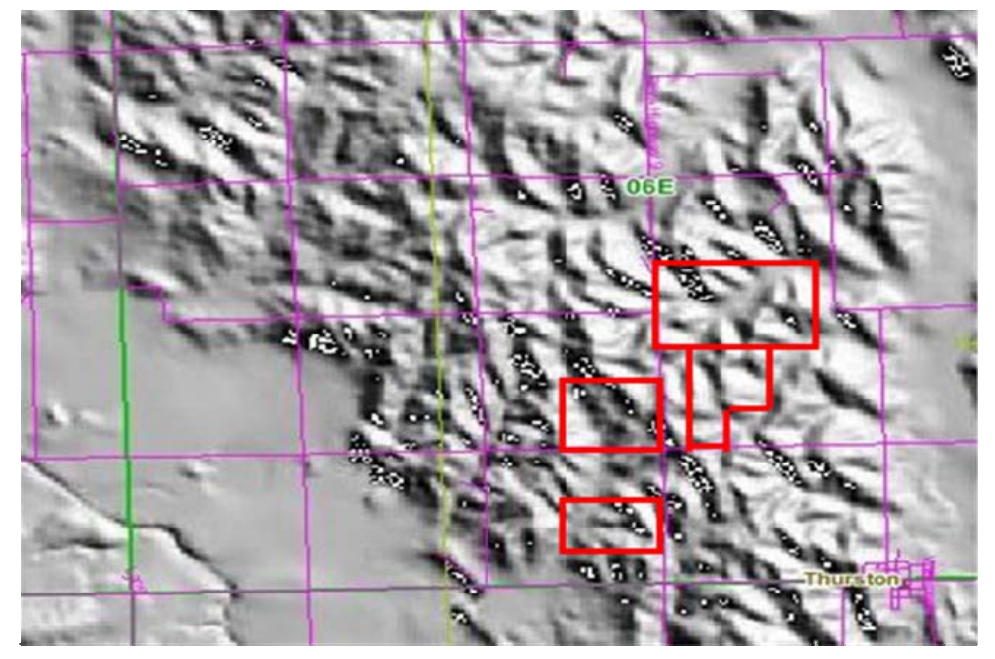

Figure 4.2-2, Western Winnebago Shaded Relief Map 
The Western Winnebago Site is characterized by moderate sloped hills and open terrain (see Figure 4.2-2). The project area has an average elevation of approximately 1,450 feet above sea level. There are no obvious wind obstructions or hindrances. The immediate surrounding area is comprised of largescale agricultural farms with two residences located within the project area boundaries. The project area is located on State Route 9 (a paved and maintained roadway) that will allow for adequate access for installation and maintenance. The land use of the immediate surrounding area is predominated by agricultural activity. All available land near the project area appears to be active use large-scale farming operations. Two residences are located directly adjacent to the project site. Figure 4.2-3 shows the locations and vantage points for the accompanying photos of the site. Figures 4.2-4 through 4.2.7 are photographs of the project site.

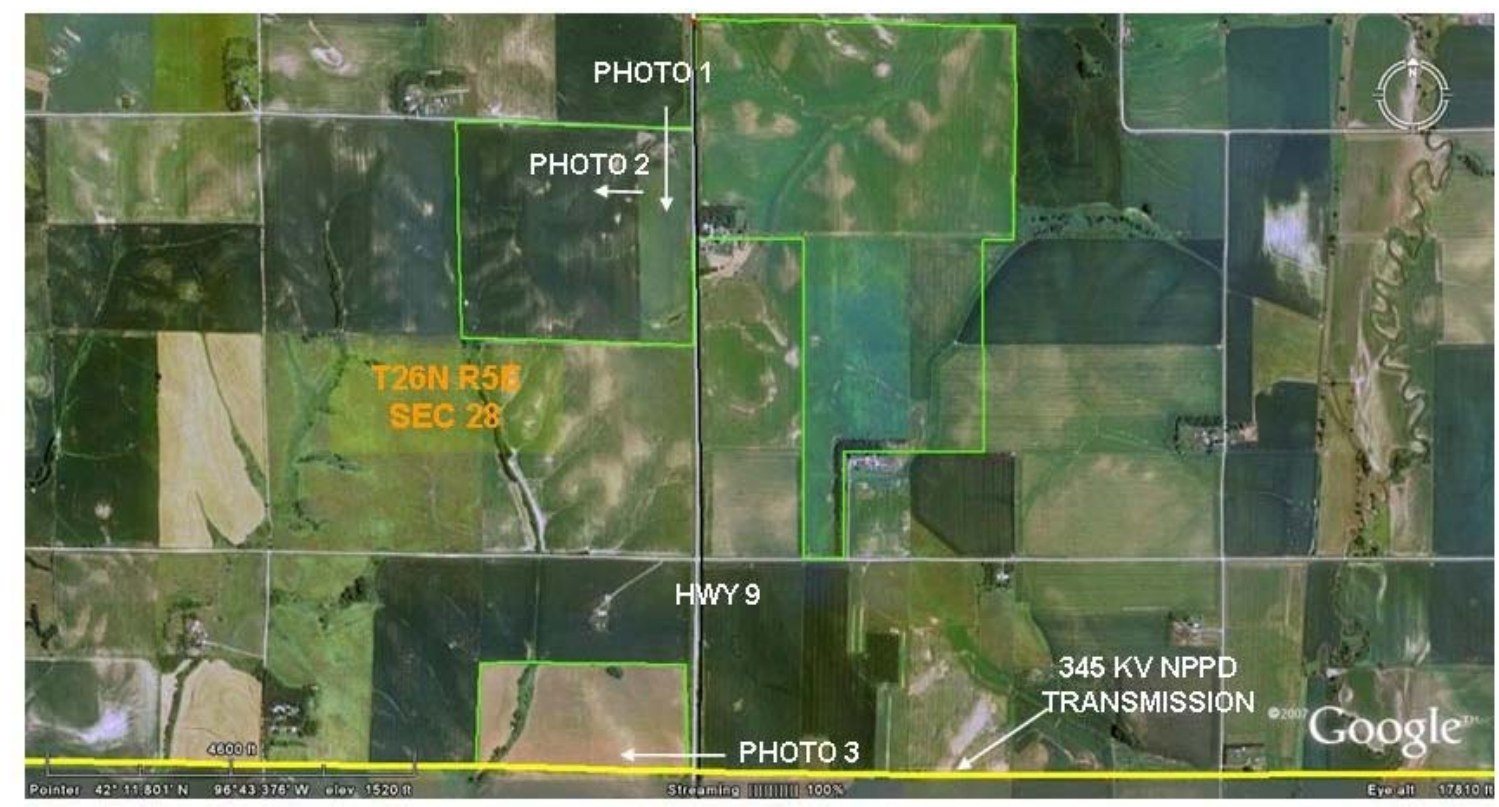

Figure 4.2-3, Western Winnebago Photo Vantage Points 


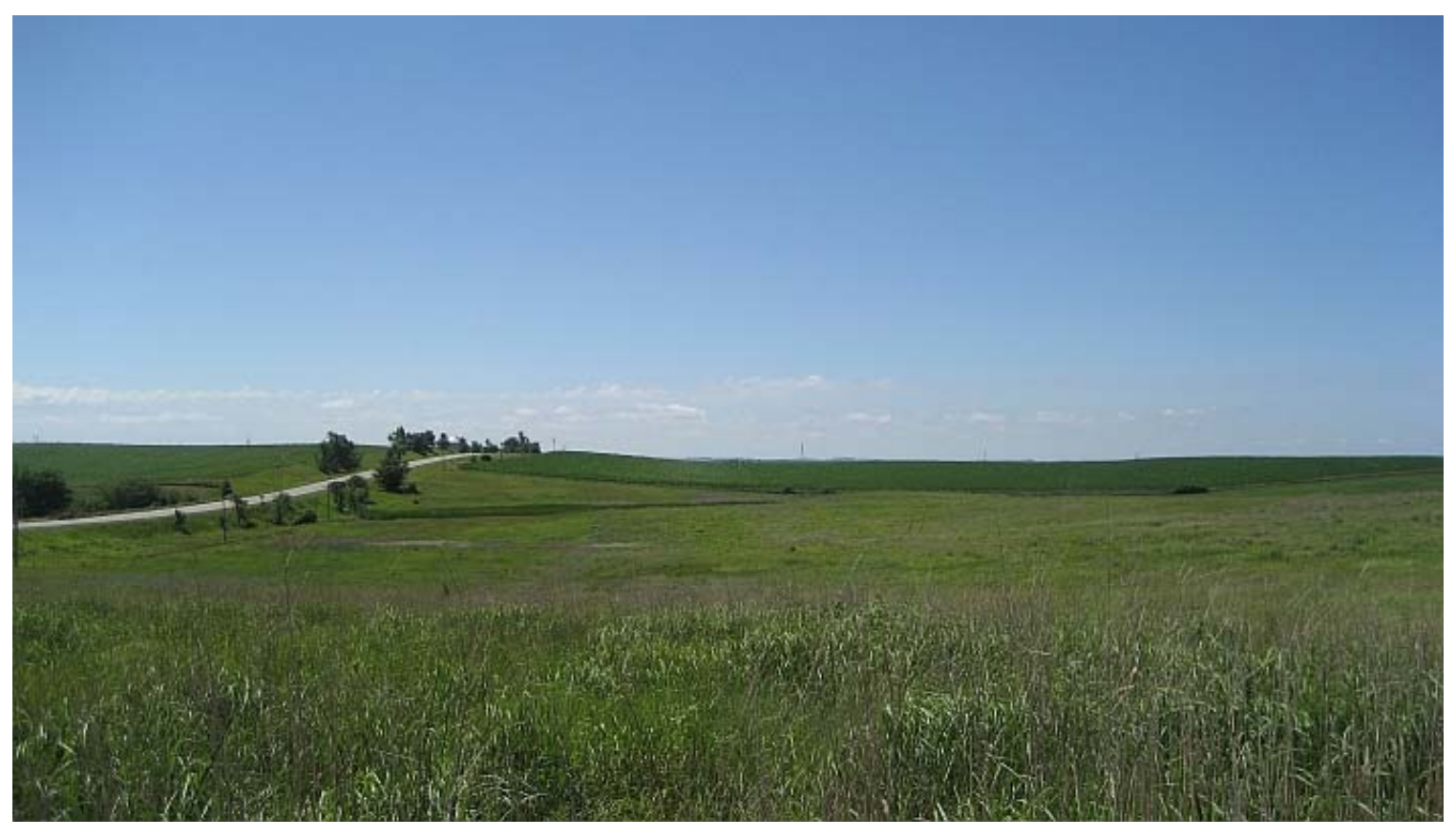

Figure 4.2-4, Looking South

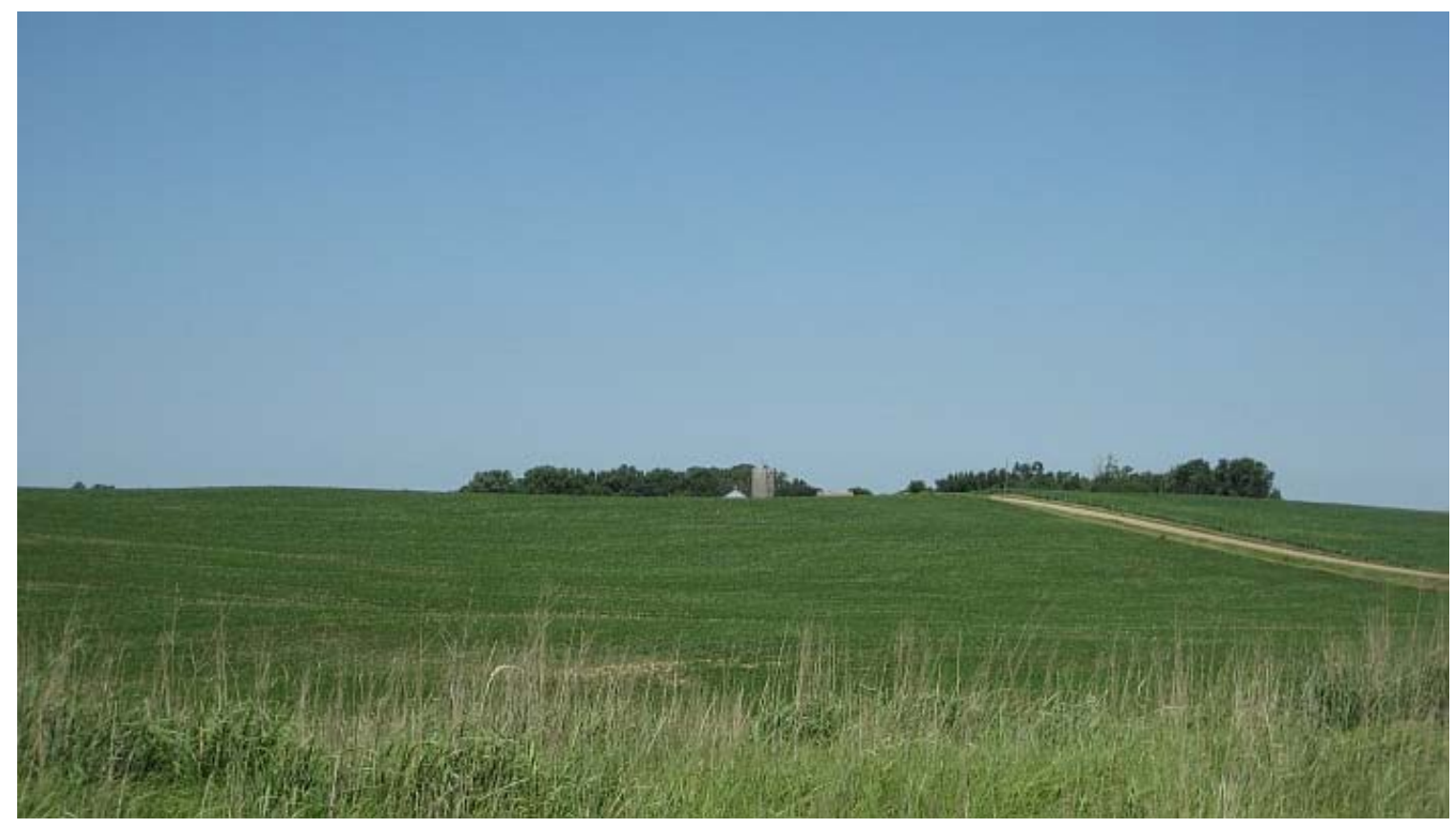

Figure 4.2-5, Looking West 


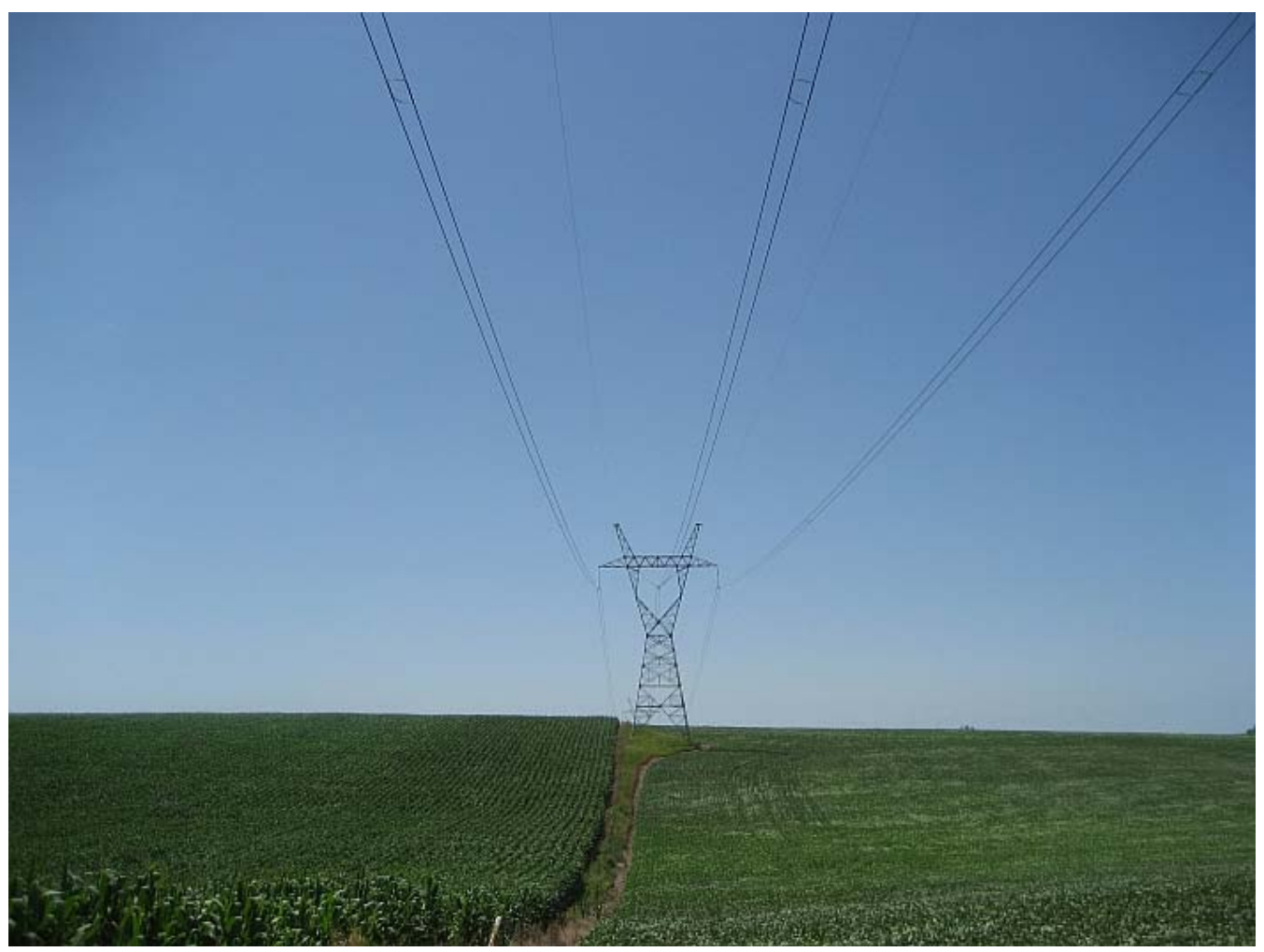

Figure 4.2-6, Looking West

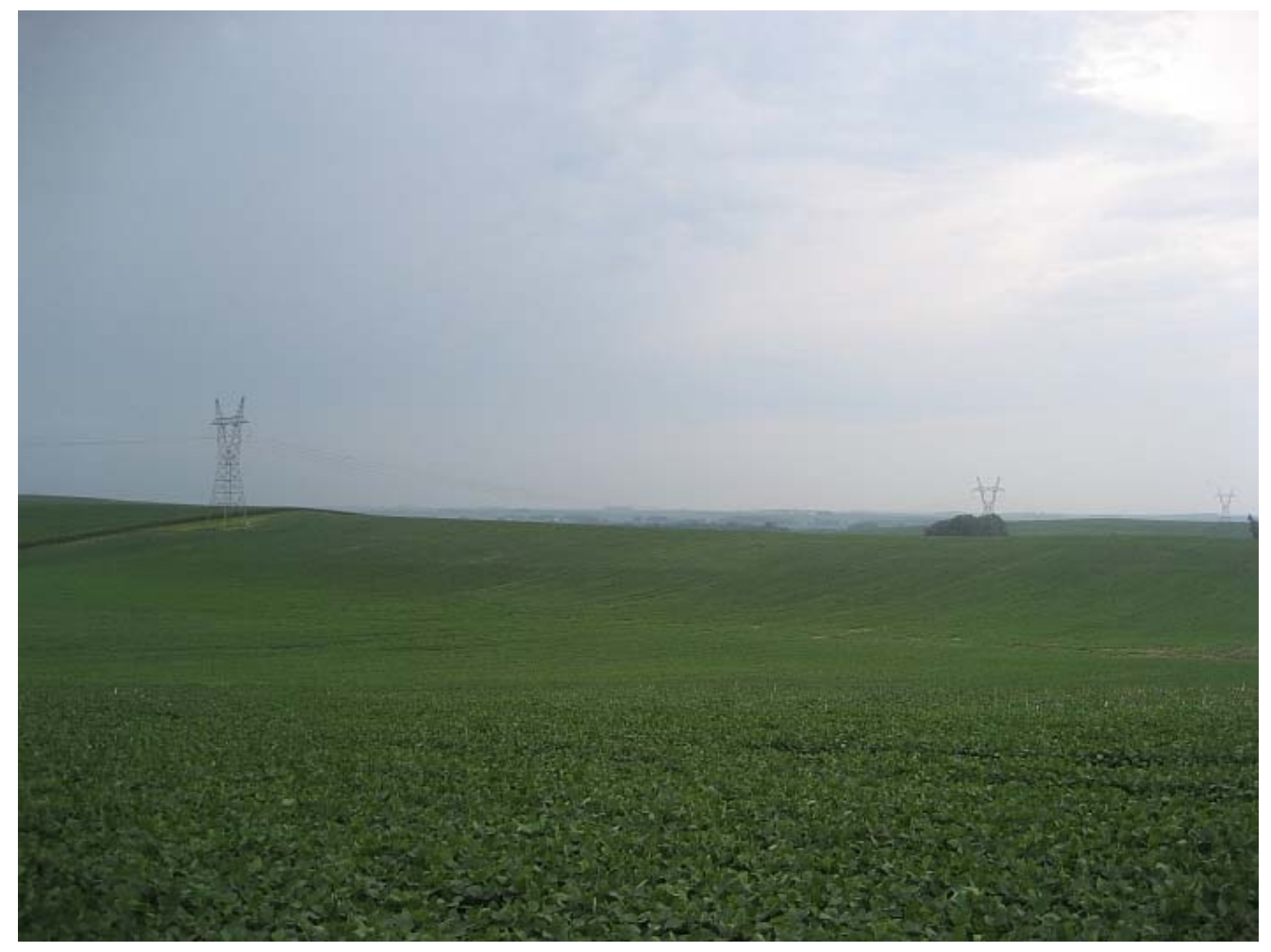

Figure 4.2-7, Looking Southwest

28 


\subsubsection{Met Tower Location and Wind Resource Assessment}

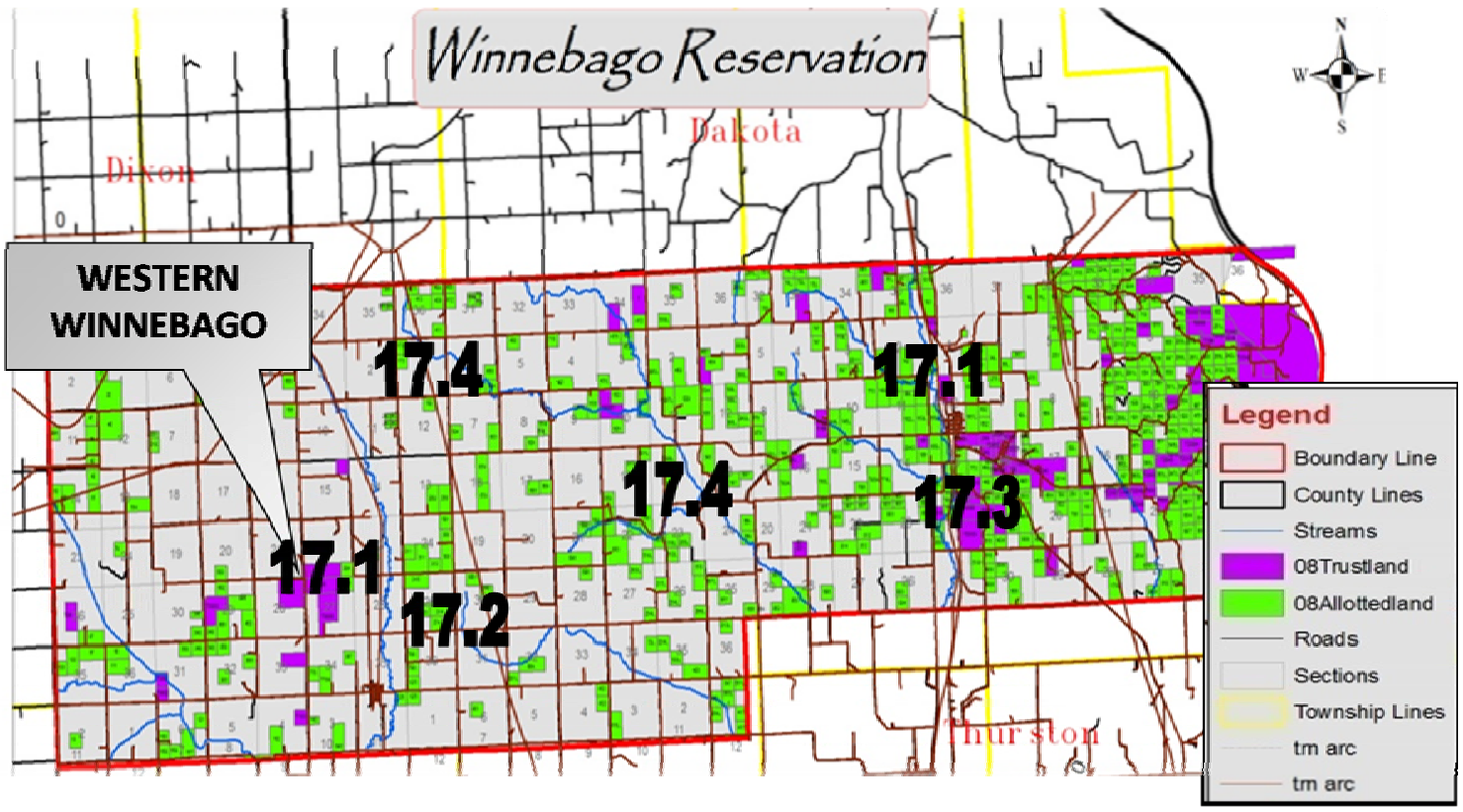

Figure 4.2.1-8, Western Winnebago Wind Resource Map

According to Windlogics data (see Figure 4.2-8), wind speeds for the Western Winnebago location were projected to be in the 17.1-17.2 mph range. According to industry standards, these class 5 wind speeds would be acceptable for wind farm development.

\subsubsection{Met Tower Location}

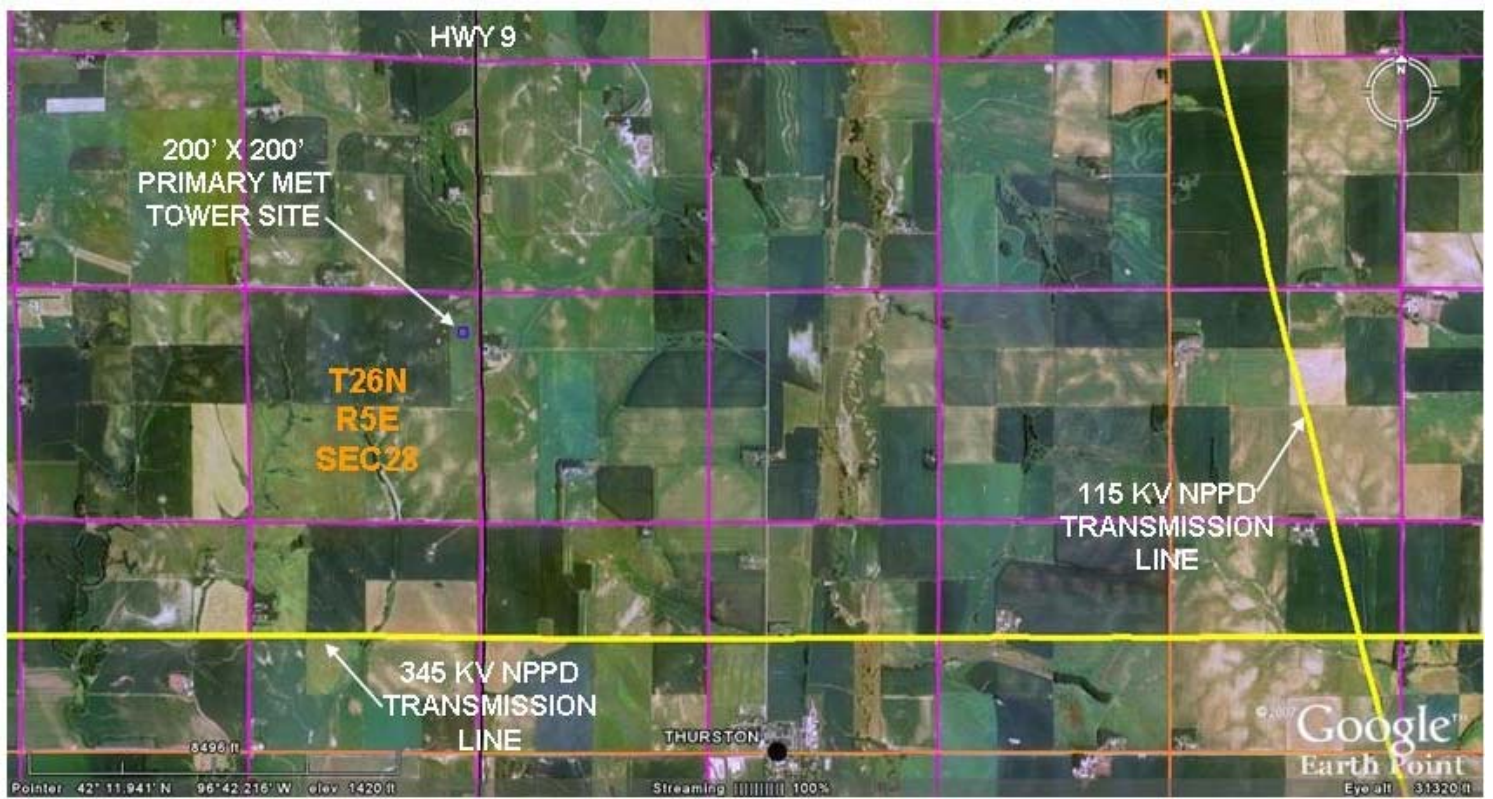

Figure 4.2-9, Primary Met Tower Site, Overview Map 
A primary met tower site was identified in the western part of the Winnebago Reservation. The site was identified in the field by Red Mountain Energy Partners staff using GPS and GIS equipment and software in 2008. This 200' X 200' site is located entirely within the northeast area of section 28 of T26N R6E of the Nebraska PLSS System (see Figure 4.2-9). This area is physically characterized by moderate sloped hills and open agricultural terrain. This site has an average elevation of approximately 1500 feet above sea level. This site is located within Thurston County near Highway 9 in the area south of Emerson. Large-scale farming and other agricultural activities predominate in and around the site location.

A met tower was installed by NPPD as part of its previously discussed efforts to identify potential wind farm sites in its service territory. The Winnebago Tribe has access to the data in support of its wind development efforts, but NPPD provided for installation and analysis of the data. Wind data for WTON is now being collected at this met tower site with an anemometer designated NPPD 9115 installed at the Western Winnebago Site at East: -96 43.6480' North: 42 12.2040' (Geo WGS 84). Data was collected beginning on 1/18/2009 and the met tower remains in place at the time of this final report submission.

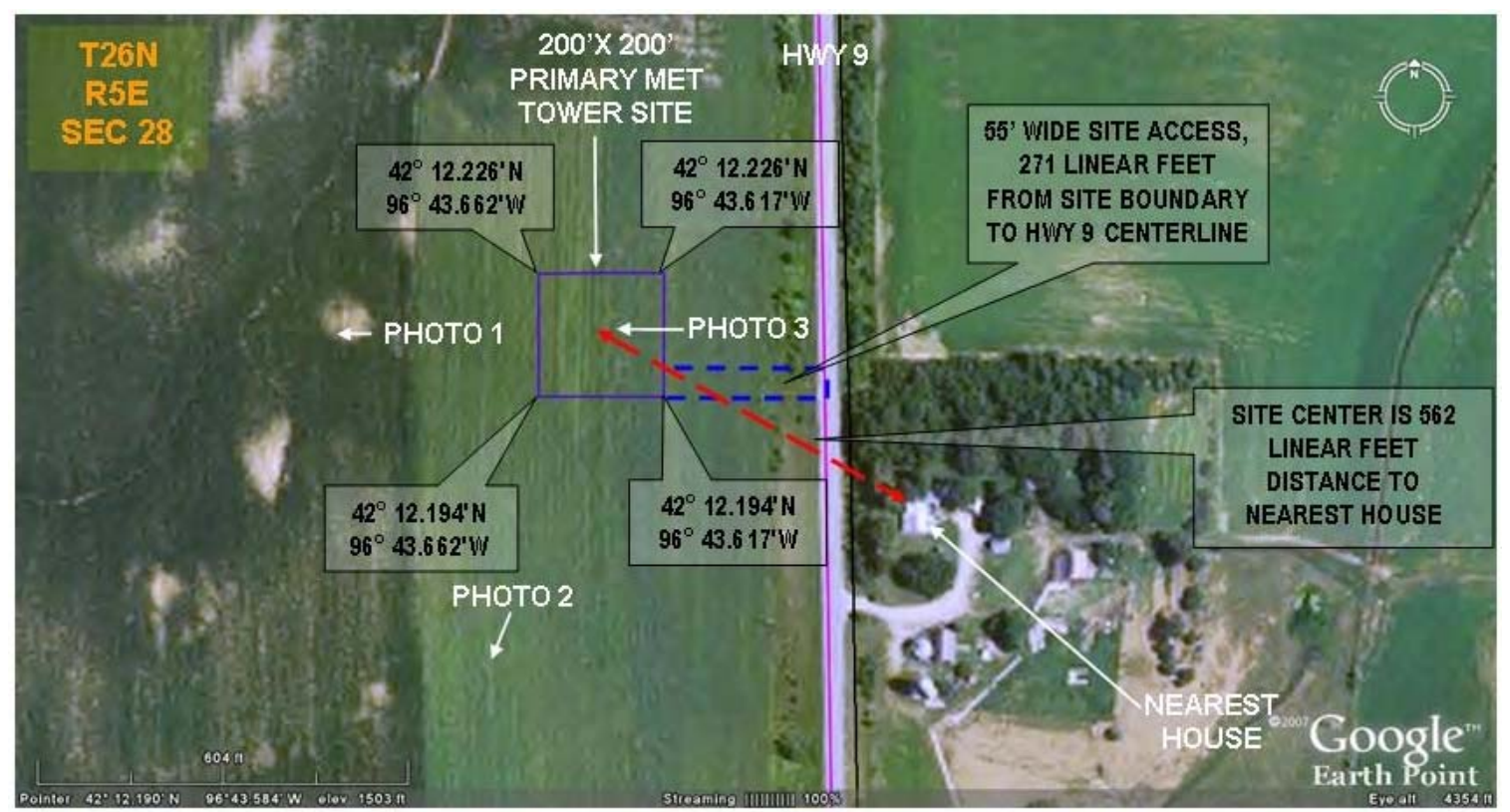

Figure 4.2-10, Primary Met Tower Site 


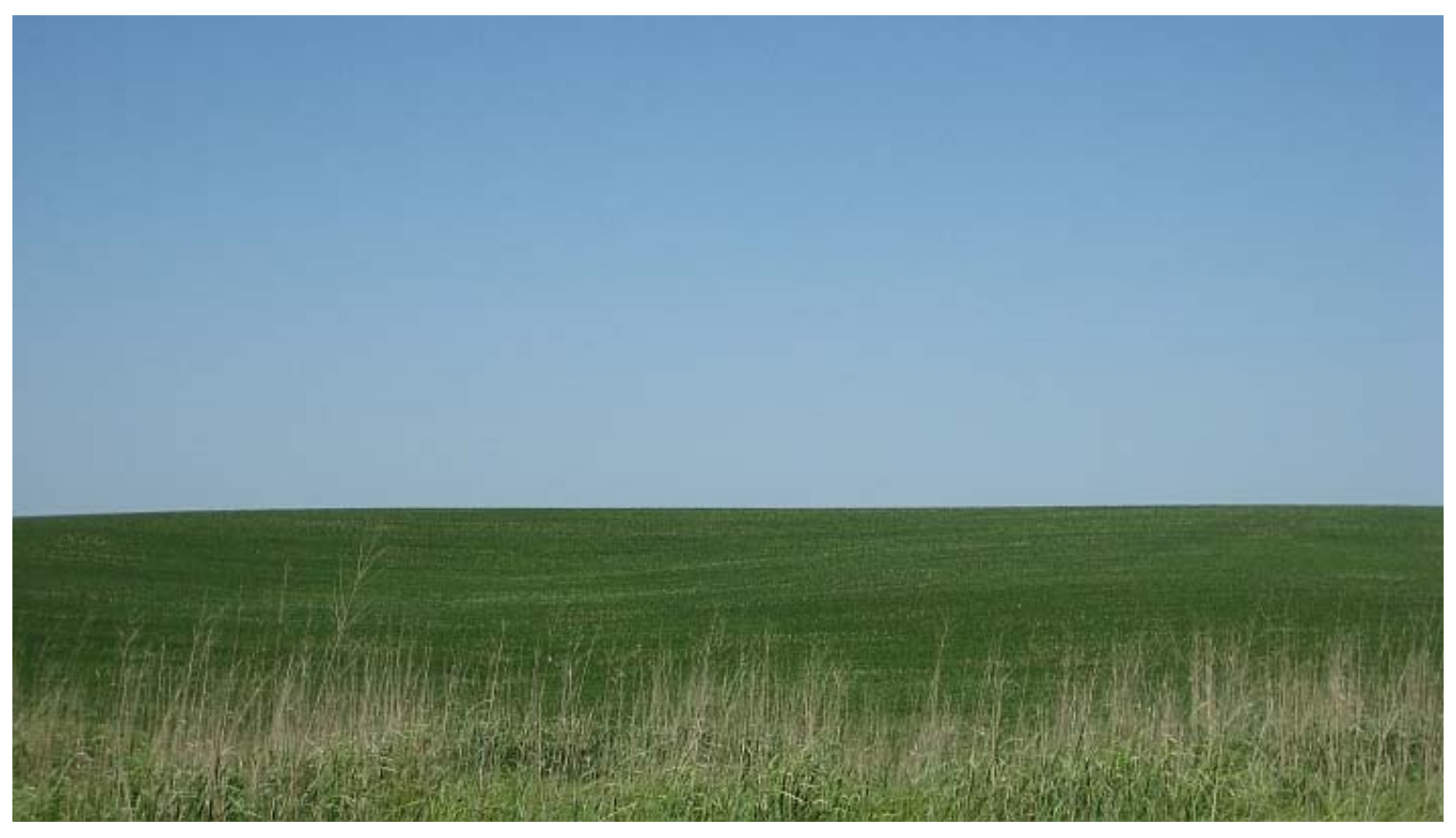

Figure 4.2-11, Looking West

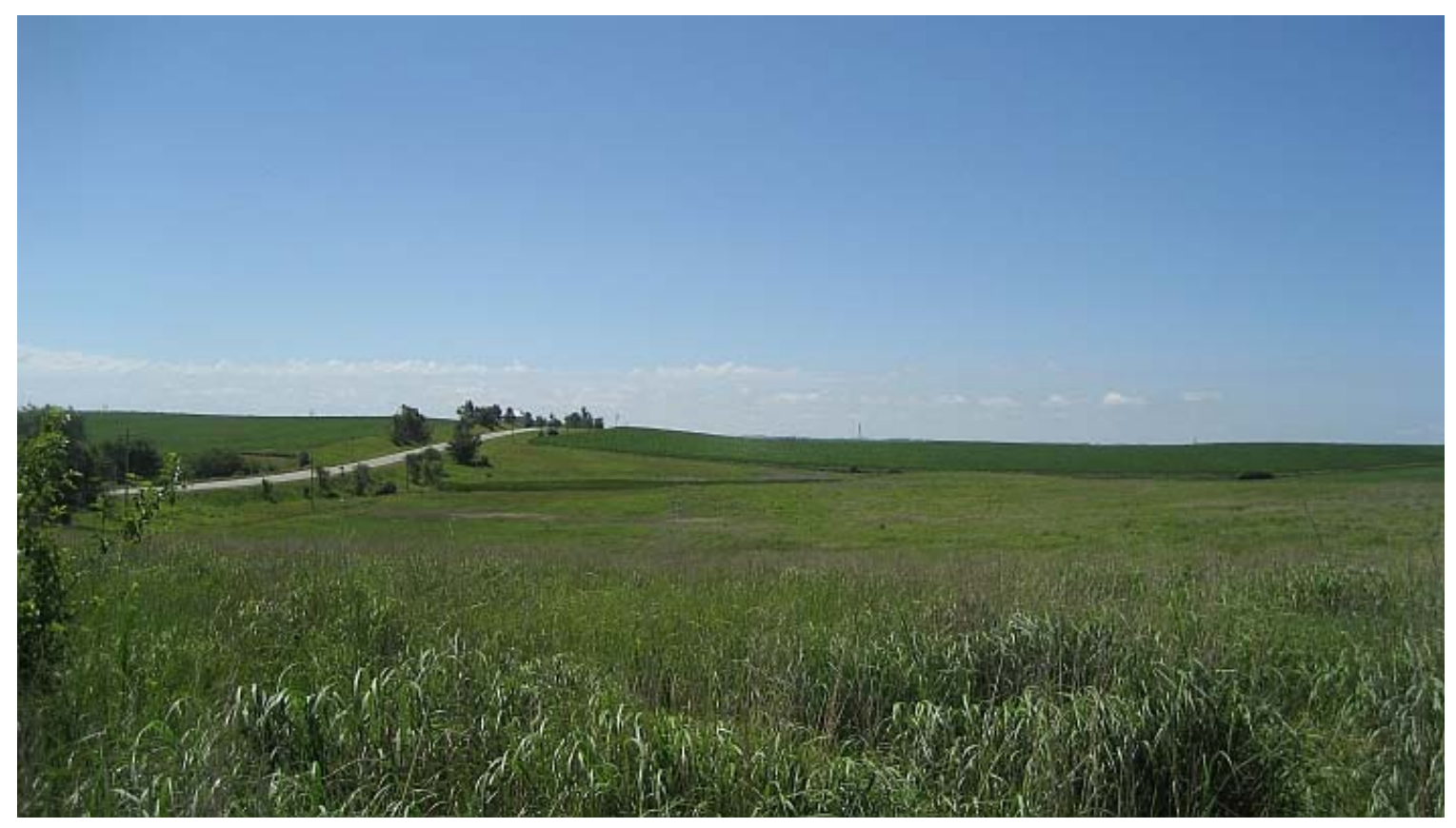

Figure 4.2-12, Looking Southeast 


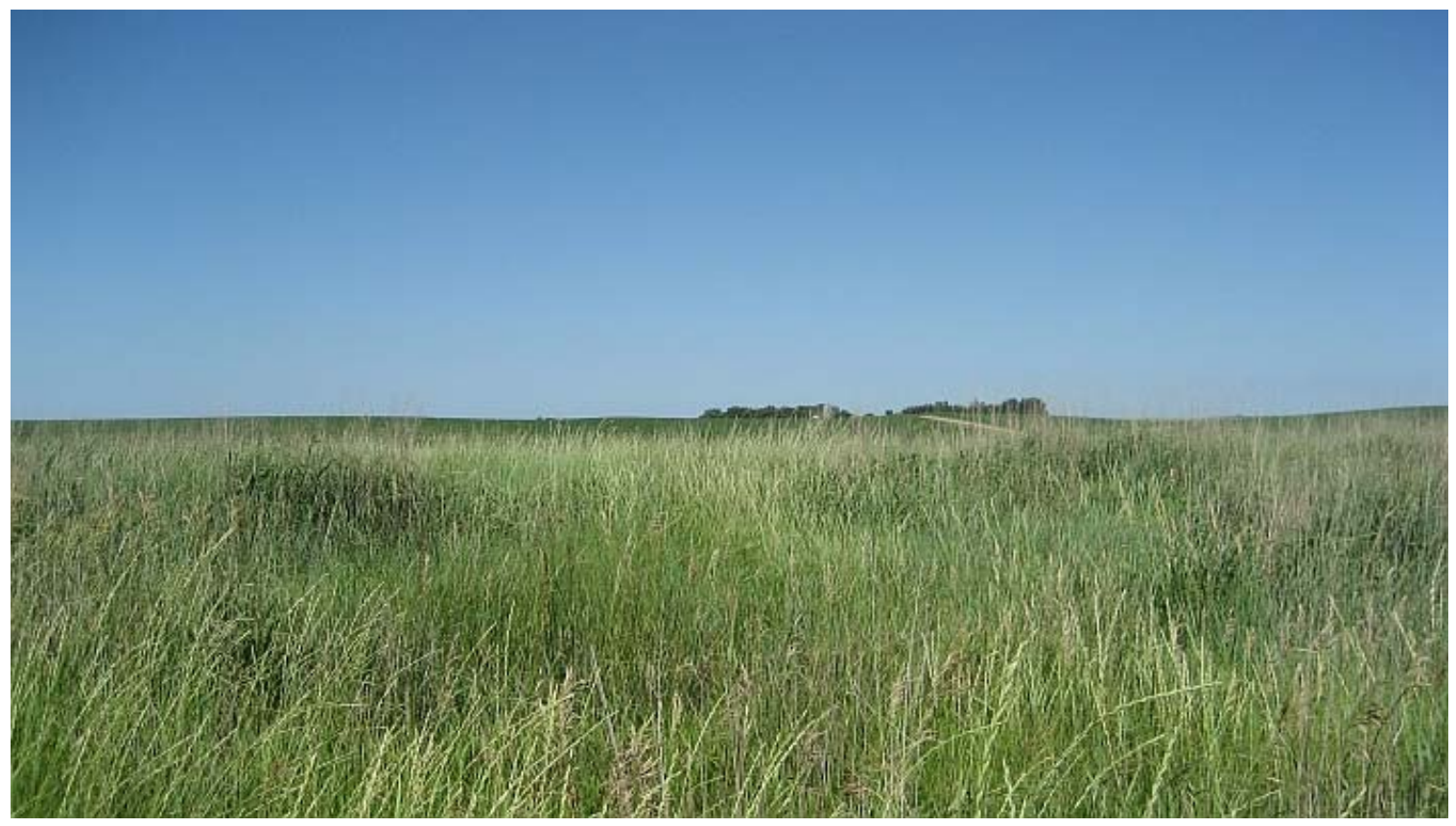

Figure 4.2-13, 200'x200' Met Tower Site

Figure 4.2-10 shows the layout and GPS coordinates of the Met Tower site. The primary met tower site has excellent road access, as it is situated directly adjacent to Highway 9 . This 200 square foot site preparation area is an approximately 271 feet linear distance directly east of the Highway 9 centerline. A 55-foot wide access road has also been designated and is shown on Figure 4.2-11.

The Tribe was engaged in a USDA CRP (US Department of Agriculture, Conservation Reserve Program) at this location, directed at farmland management and environmental protection of environmentally sensitive land areas. The program expired on September 19, 2008, making this location available for met tower installation after that date.

\subsubsection{Met Tower Data Assessment}

Wind data for Winnebago is being collected with an anemometer designated NPPD 9115 installed at the Western Winnebago Site at East: -96 43.6480' North: 42 12.2040' (Geo WGS 84). Data collected for the initial seven-month period beginning on 1/18/2009 and ending on 8/4//2009 is summarized below. 

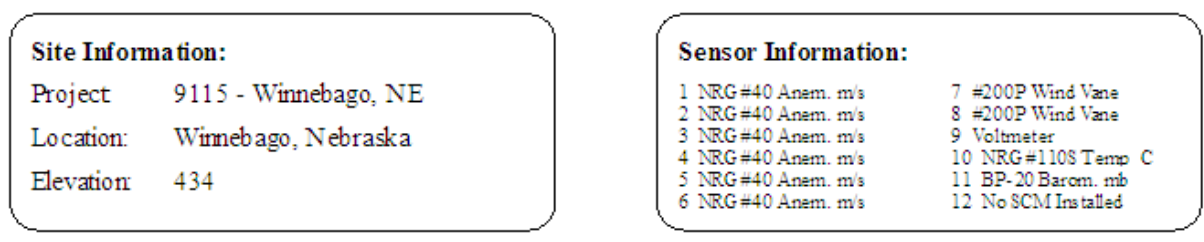

1/18/2009 to 8/4/2009

Summary Report

STE 9115

9115 - Wimeb ago, NE

\begin{tabular}{|c|c|c|c|c|c|c|c|c|c|c|c|c|}
\hline Channel & 1 & 2 & 3 & 4 & 5 & 6 & 7 & 8 & 9 & 10 & 11 & \\
\hline Height & 59.28 & 59.28 & 49.99 & 49.99 & 40.01 & 31.39 & 58.17 & 49.07 & $1 \mathrm{~m}$ & $3 \mathrm{~m}$ & $1 \mathrm{~m}$ & $\cdots$ \\
\hline Units & $\mathrm{m} / \mathrm{s}$ & $\mathrm{m} / \mathrm{s}$ & $\mathrm{m} / \mathrm{s}$ & $\mathrm{m} / \mathrm{s}$ & $\mathrm{m} / \mathrm{s}$ & $\mathrm{m} / \mathrm{s}$ & des & deg & Volts & c) & $\mathrm{mb}$ & $\cdots$ \\
\hline Intervals with Valid Data & 28656 & 28656 & 28656 & 28656 & 28656 & 28656 & 28656 & 28656 & 28656 & 28656 & 28656 & \\
\hline Average Filtered Data & 7.16 & 7.19 & 7.02 & 7.04 & 6.76 & 6.32 & 353.15 & 355.3 & 13.76 & 10.22 & 957.86 & \\
\hline Average for All Data & 7.16 & 7.19 & 7.02 & 7.04 & 6.76 & 6.32 & 353.15 & 355.3 & 13.76 & 10.22 & 957.86 & \\
\hline Min Interval Average & 0.37 & 0.33 & 0.36 & 0.37 & 0.32 & 0.36 & & & 13.1 & -22.53 & 928.1 & \\
\hline Date of Min Interval & $1 / 25 / 2009$ & $1 / 242009$ & $1 / 25 / 2009$ & $1 / 24 / 2009$ & $1 / 24 / 2009$ & $1 / 222009$ & & & $1 / 182009$ & $3 / 12009$ & $29 / 2009$ & \\
\hline Time of Min Interval & 8:10:00 PM & $6: 30: 00 \mathrm{PM}$ & 5:50:00 PM & 6:30:00 PM & 6:30:00 PM & 12:50:00 PM & & & 4:20:00 AM & 6:00:00 AM & 7:30:00 PM & \\
\hline Max Interval Average & 23.3 & 22.92 & 22.62 & 22.79 & 21.97 & 21.33 & & & 14.9 & 36.24 & 978.7 & \\
\hline Date of Max Interval & $29 / 2009$ & $2 / 92009$ & $29 / 2009$ & $29 / 2009$ & 29,2009 & $2 / 92009$ & & & $1 / 242009$ & $6 / 222009$ & $3 / 1 / 2009$ & \\
\hline Time of Max Internal & $8: 10: 00 \mathrm{PM}$ & $8: 10: 00 \mathrm{PM}$ & 8:10:00 PM & 8:10:00 PM & 8:10:00 PM & 7:30:00 PM & & & $8: 20: 00 \mathrm{AM}$ & 3:20:00 PM & $11: 10: 00 \mathrm{AM}$ & \\
\hline Average Interval SD & 0.67 & 0.67 & 0.69 & 0.69 & 0.71 & 0.72 & 5.88 & 6.13 & 0 & 0.05 & 0.01 & \\
\hline Min Sample & 0.37 & 0.33 & 0.36 & 0.37 & 0.32 & 0.36 & & & 12.9 & -22.7 & 926.9 & \\
\hline Date of Min Sample & 2192009 & $2 / 192009$ & 2/19/2009 & $219 / 2009$ & 219,2009 & $2 / 192009$ & & & $4 / 29,2009$ & 3/12009 & $29 / 2009$ & \\
\hline Time of Min Sample & $12: 00: 00 \mathrm{PM}$ & $12: 40: 00 \mathrm{PM}$ & $12: 40: 00 \mathrm{PM}$ & $12: 50: 00 \mathrm{PM}$ & $12: 00: 00 \mathrm{PM}$ & $12: 20: 00 \mathrm{PM}$ & & & $1: 30: 00 \mathrm{PM}$ & 6:00:00 AM & 8:00:00 PM & \\
\hline Max Sample & 31.45 & 32.25 & 31.06 & 31.83 & 30.77 & 29.56 & & & 15.3 & 36.57 & 979.1 & \\
\hline Date of Max Sample & 292009 & 2,92009 & $29 / 2009$ & $29 / 2009$ & 292009 & 2,92009 & & & $3 / 11 / 2009$ & $6 / 222009$ & $3 / 1 / 2009$ & \\
\hline Time of Max Sample & $7: 30: 00 \mathrm{PM}$ & $7: 30: 00 \mathrm{PM}$ & $7: 30: 00 \mathrm{PM}$ & 7:30:00 PM & $7: 30: 00 \mathrm{PM}$ & 7:30:00 PM & & & 1:30:00 PM & 3:20:00 PM & 10:00:00 AM & \\
\hline Average Interval II & 0.1 & 0.11 & 0.11 & 0.11 & 0.12 & 0.12 & & & & & & \\
\hline Wind Speed Direction & & & & & & & NNw & NNw & & & & \\
\hline
\end{tabular}

Figure 4.2-12, Summary Report for NPPD 9115, 1/18/2009-8/4/2009

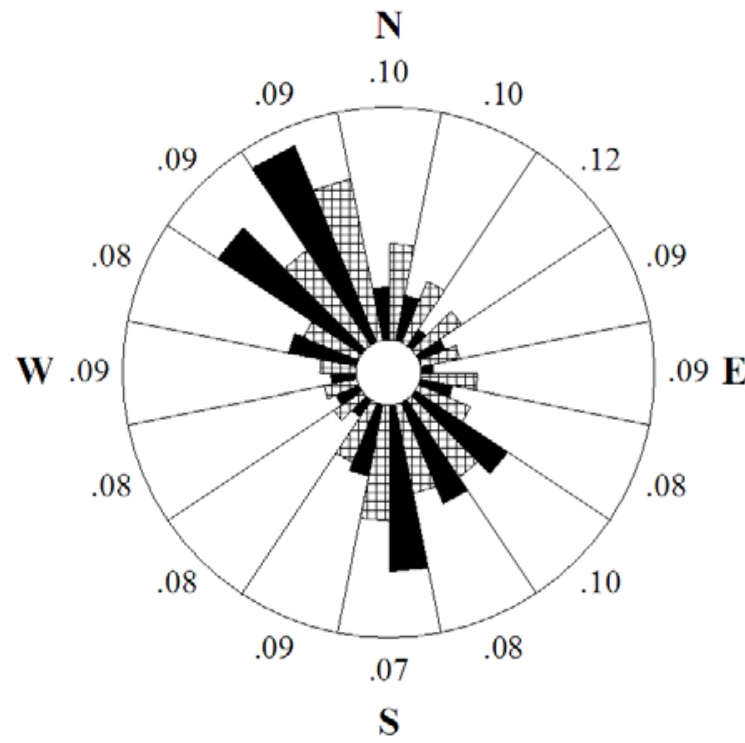

\begin{tabular}{|c|c|}
\hline \multicolumn{2}{|c|}{$\begin{array}{c}\text { 1/18/2009 to } \mathbf{8} / \mathbf{4} / \mathbf{2 0 0 9} \\
\text { Wind Rose Ch } 1,7 \\
\text { SITE } 9115 \\
\text { 9115- Wimeb } 280, \mathrm{NE}\end{array}$} \\
\hline \multicolumn{2}{|c|}{ Site Information: } \\
\hline Project: & 9115 - Winebago, NE \\
\hline Location: & Winueb ago, Nebraska \\
\hline Elerxion & 434 \\
\hline \multirow{2}{*}{\multicolumn{2}{|c|}{$\begin{array}{l}\text { Anemometer on cha anel } 1 \text { : } \\
N R G=40 \text { Anem. } \mathrm{m} / \mathrm{s}\end{array}$}} \\
\hline & \\
\hline Heiglt & 59.28 \\
\hline Serial $=$ & SN:7594S \\
\hline \multicolumn{2}{|c|}{$\begin{array}{l}\text { Vaue ou channel } 7 \text { : } \\
=200 \mathrm{P} \text { Wind Vane }\end{array}$} \\
\hline Height & 58.17 \\
\hline Serial it: & $\mathrm{sN}$ \\
\hline \multicolumn{2}{|c|}{$\begin{array}{l}\text { Oute Numbes are Average TIs } \\
\text { for speeds geater than } 4.5 \mathrm{~m} / \mathrm{s}\end{array}$} \\
\hline \multicolumn{2}{|c|}{ Irruer Circle $=0 \%$} \\
\hline \multicolumn{2}{|c|}{ Outer Cride $=20 \%$} \\
\hline \multicolumn{2}{|c|}{ Percent of Total Whid Enery } \\
\hline 曲Per & of of Total Time \\
\hline
\end{tabular}

Figure 4.2-13, Wind Direction Distribution 
The data collected for NPPD 9115 for the period from 1/18/2009 to 8/4/2009 indicates that at a height of 59 meters, the arithmetic mean wind speed was nominally 7.2 meters per second. Also, the wind distribution graph indicates that at heights of 59.0 meters, the wind profile is most frequent in the NNW sector of the wind rose.

The data collected by NPPD 9115 indicates that at a height of 50 meters for the period from 1/18/2009 to $8 / 4 / 2009$, the wind regime could be considered Class 4 and suitable for utility-scale wind turbine applications according to the National Renewable Energy Laboratory (NREL) wind class standards.

Figure 4.2-14 shows the various wind classes at both 10-meter and 50-meter turbine hub heights.

\begin{tabular}{|c|c|c|c|c|}
\hline \multirow{2}{*}{$\begin{array}{l}\text { Wind Power } \\
\text { Class }\end{array}$} & \multicolumn{2}{|c|}{$10 \mathrm{~m}(33 \mathrm{ft})$} & \multicolumn{2}{|c|}{$50 \mathrm{~m}(164 \mathrm{ft})$} \\
\hline & $\begin{array}{l}\text { Wind Power Density } \\
\text { (W/m 2) }\end{array}$ & Speed (b) m/s (mph) & $\begin{array}{l}\text { Wind Power Density } \\
\qquad(\mathrm{W} / \mathrm{m} 2)\end{array}$ & Speed (b) $\mathrm{m} / \mathrm{s}(\mathrm{mph})$ \\
\hline 1 & 0 & 0 & 0 & \\
\hline 2 & 100 & $4.4(9.8)$ & 200 & $5.6(12.5)$ \\
\hline 3 & 150 & $5.1(11.5)$ & 300 & $6.4(14.3)$ \\
\hline 4 & 200 & $5.6(12.5)$ & 400 & $7.0(15.7)$ \\
\hline 5 & 250 & $6.0(13.4)$ & 500 & $7.5(16.8)$ \\
\hline 6 & 300 & $6.4(14.3)$ & 600 & $8.0(17.9)$ \\
\hline \multirow{2}{*}{7} & 400 & $7.0(15.7)$ & 800 & $8.8(19.7)$ \\
\hline & 1000 & $9.4(21.1)$ & 2000 & $11.9(26.6)$ \\
\hline
\end{tabular}

Figure 4.2-14, Wind Power Density Classes at 10M and 50M

*1) Vertical extrapolation of wind speed based on the 1/7 power law

*2) Mean wind speed is based on Rayleigh speed distribution of equivalent mean wind power density. Wind speed is for standard sea-level conditions. To maintain the same power density, speed increases 3\%/1000 m (5\%/5000 ft) elevation. 


\subsubsection{Project Layout and Design}

A preliminary layout (see Figure 4.2-15) was designed with Vestas N82 wind turbines. The N82 model is a1.65 MW turbine and can be installed at a height of 70 or 80 meters (230 or 262 feet). The layout was developed utilizing design considerations required in some states that serve to minimize flicker, noise and interference for residents who live near wind farms and individual turbines.

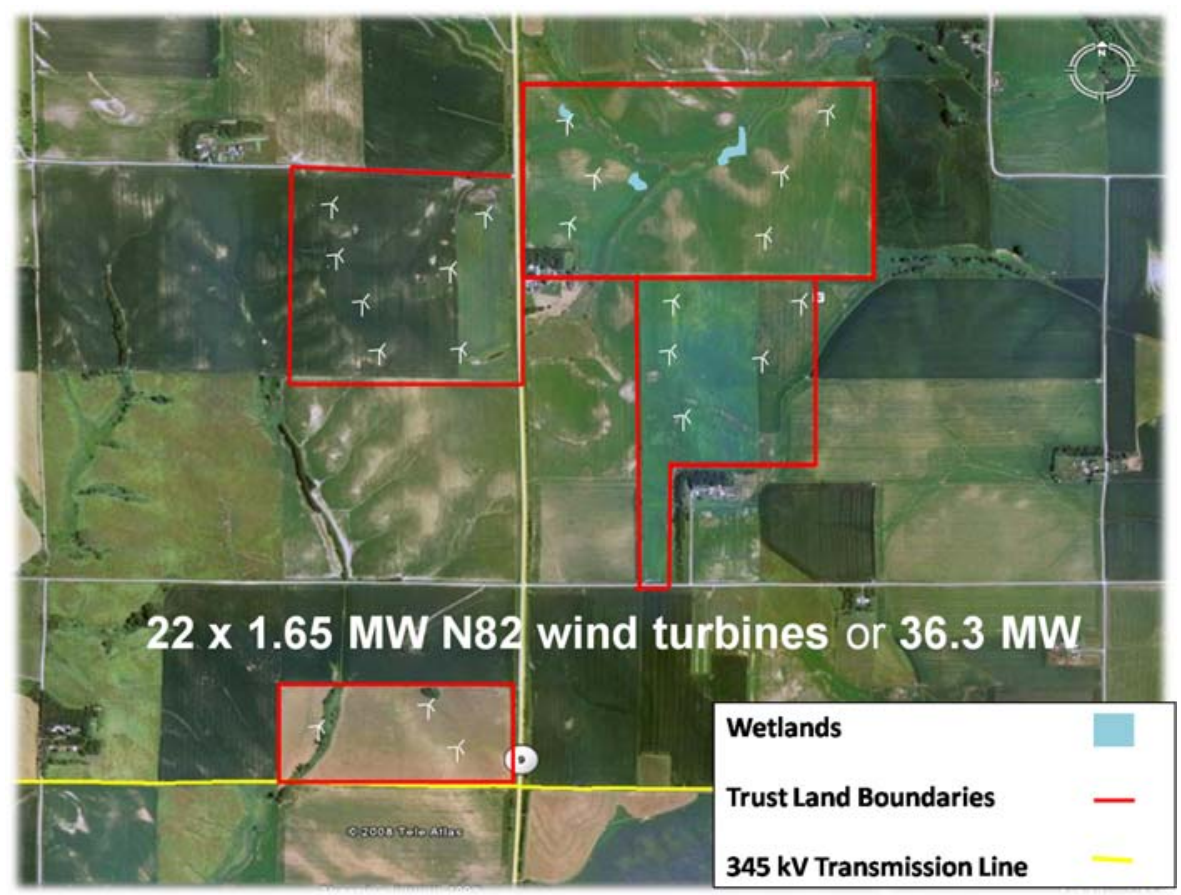

Figure 4.2.4-15, 36.3 MW Layout Design

Figure 4.2-16 lists average setbacks for wind turbines from residential units, property lines, road rights of way, wetlands, and conservation lands, many of which are based on the turbine height.

\begin{tabular}{|l|c|}
\hline \multicolumn{1}{|c|}{ Sethacks } & ft \\
\hline Homes & $\mathbf{7 5 0}$ \\
\hline Property lines & 290 \\
\hline Roed Rights of Way & 205 \\
\hline Certain Wetands & $\mathbf{6 0 0}$ \\
\hline Conservation Land & $\mathbf{6 0 0}$ \\
\hline
\end{tabular}

Figure 4.2.4-16, Average Setback Requirement

Another design consideration is spacing between the turbines. Spacing between turbines and rows minimizes energy losses that can result from one turbine potentially "stealing" wind from another turbine. For the Vestas N82 turbine, the minimum spacing between turbines is $810 \mathrm{ft}$ while the minimum spacing between rows is 1,345 ft. Figure 4.4-3 shows the wind farm layout at close to ground level illustrating geographical contours of the site. The Western Winnebago trust land location has the 
capacity to hold approximately $22 \times 1.65 \mathrm{MW}$ N82 wind turbines or $36.3 \mathrm{MW}$. Also of note in Figure 4.2-17 is the residential area to nearest turbine distance of 1,100 feet.

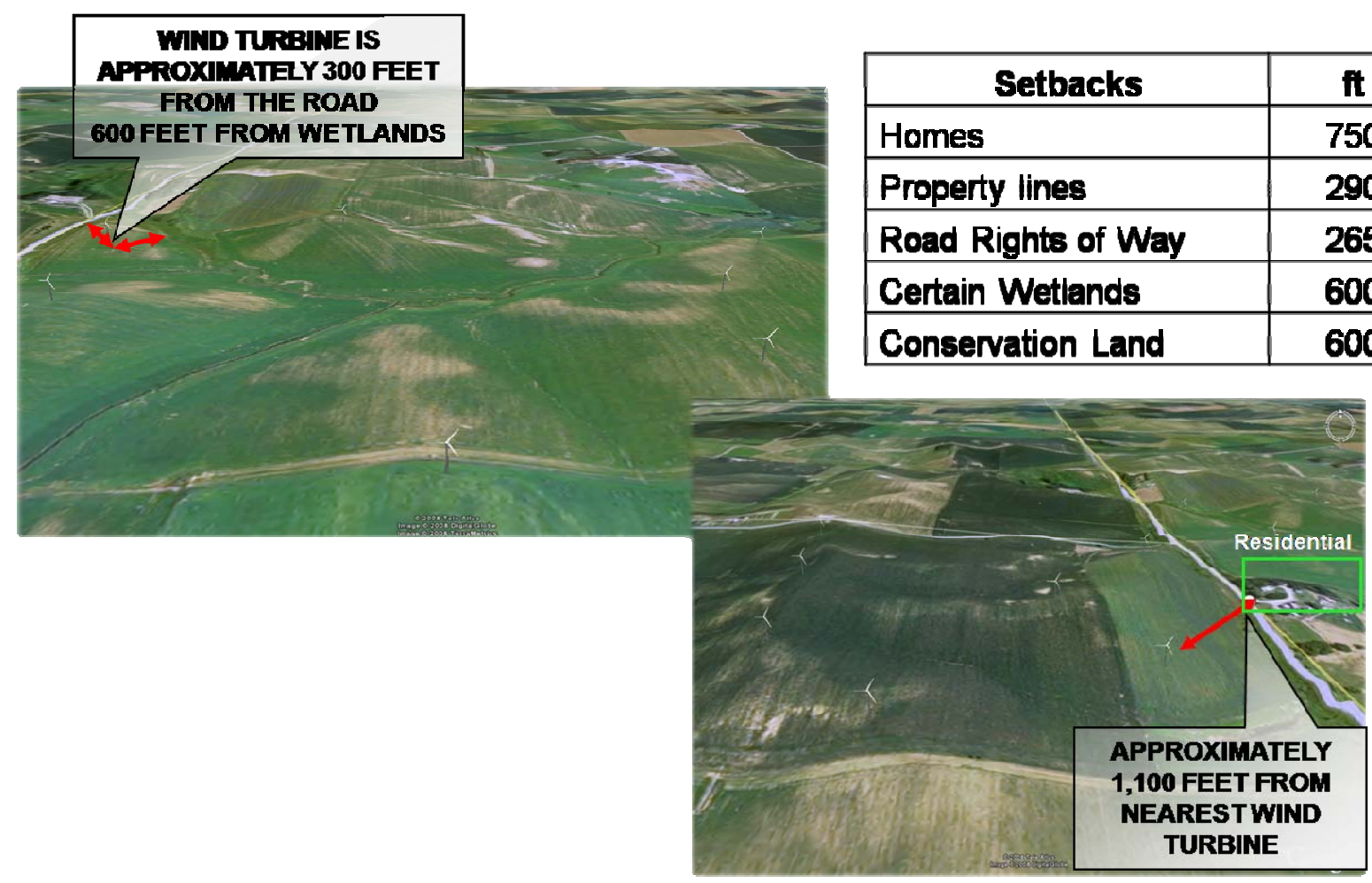

Figure 4.2.4-17, Site Contour and Setbacks

\subsubsection{Wind Production and Project Cost Analysis}

Wind production was calculated based on the initial projections of wind speed provided by WindLogics, as shown in Figure 4.2-17. Under that assumption, a 36.3 MW wind farm in Western Winnebago would generate approximately 99,139,991 kWh and have a capacity factor of $31.2 \%$.

\begin{tabular}{|c|c|c|c|}
\hline & $\begin{array}{c}\text { Prolect } \\
\text { Size } \\
\text { Site Dascription }\end{array}$ & $\begin{array}{c}\text { Average } \\
\text { Wind Speed } \\
\text { M. } 80 \mathrm{~m}, \mathrm{mph}\end{array}$ & $\begin{array}{c}\text { Average Total } \\
\text { Annual Energy } \\
\text { WWh }\end{array}$ \\
\hline Westem Winnebego & 36.3 & 17.1 & $99,138,991$ \\
\hline
\end{tabular}

Figure 4.2.17, Initial Wind Production Projections

A preliminary cost estimate for the wind farm was generated based on estimates provided by NPPD and estimates previously gathered for WinnaVegas. In addition, a cost and production estimate was later prepared assuming use of GE 1.5 xle turbines. The cost and production comparisons are shown in Figure 4.2-18. 
Figure 4.2-18, Western Winnebago Wind Farm Estimated Cost and Production Comparison

\begin{tabular}{|lll|}
\multicolumn{1}{c}{ Attribute } & \multicolumn{1}{c|}{ GE 1.5xle } & \multicolumn{1}{c|}{ Vestas N82 } \\
\hline Wind speed $(\mathrm{m} / \mathrm{s})$ & 7.64 & 7.64 \\
\hline Turbine power rating $(\mathrm{kW})$ & 1500 & 1650 \\
\hline Capacity installed $(\mathrm{MW})(12$ turbines at site) & 33 & 36.9 \\
\hline Turbine price (\$) (incl. tower \& erection) & $\$ 2,100,000$ & $\$ 2,128,500$ \\
\hline Availability (\%) & $97 \%$ & $97 \%$ \\
\hline Net Capacity Factor (\%) & $44 \%$ & $31 \%$ \\
\hline Total Annual Production to meter (MWh) & 124,690 & 113,824 \\
\hline Project Life (years) & 25 & 25 \\
\hline
\end{tabular}

Operation and Maintenance (O\&M) costs were estimated based on US trends for O\&M costs (see Figure 3.8-3). According to Figure 4.5-2, O\&M costs were approximately $\$ 12 / \mathrm{MWh}$ for 2007 projects.

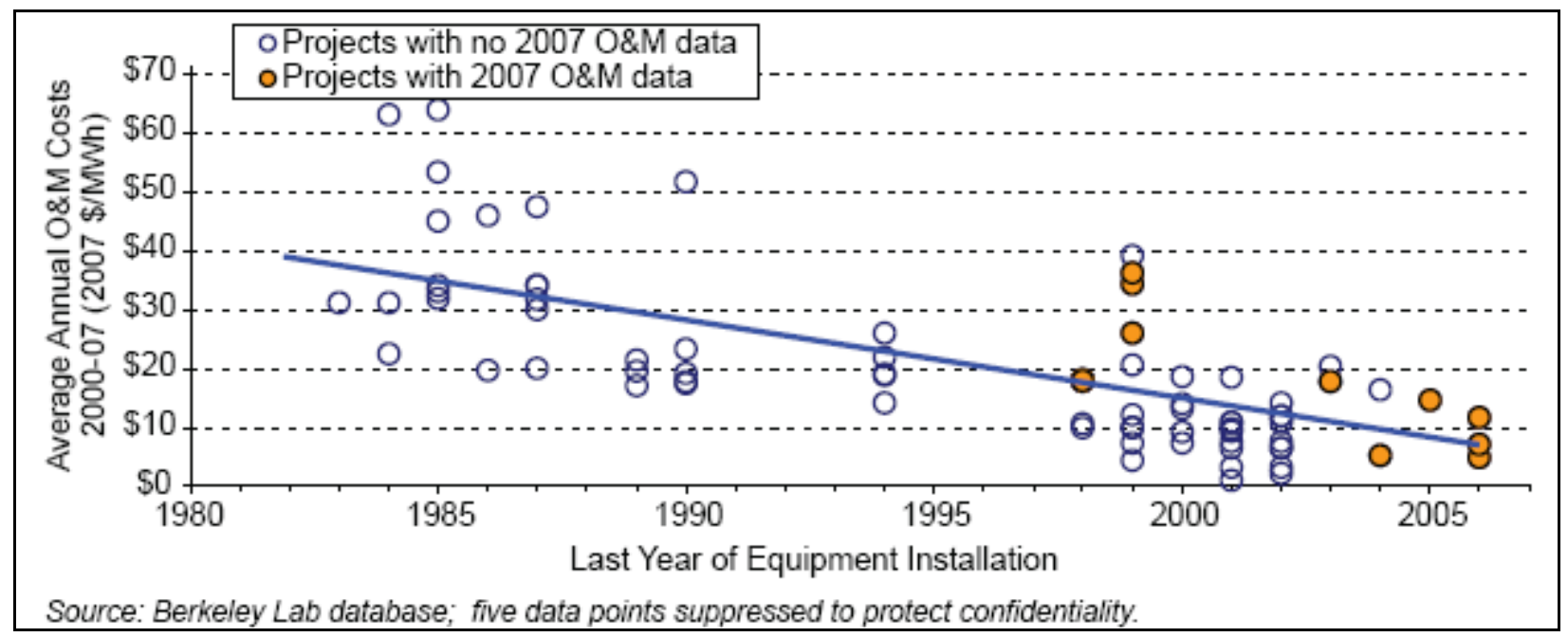

Figure 4.2-19, US O\&M Costs from 2000-2007

The Levelized Replacement Cost (LRC) was estimated at $20 \%$ of the capital equipment costs and estimated over twenty years. The LRC is associated with major overhauls and component replacements over the life of a wind turbine. Equipment reliability directly affects the LRC in that the LRC figure is only as accurate as the component life estimates. Difficulty in assigning accurate usefullife figures to turbine components makes the LRC cost component less predictable than the O\& $M$ component. 


\begin{tabular}{|c|c|c|c|c|c|c|}
\hline Annual Costs (Credits) & Unit & Quantity & \multicolumn{3}{|c|}{ Unit Cost } & Amount \\
\hline \multicolumn{7}{|l|}{ O\&M } \\
\hline Insurance premium & \multirow{2}{*}{$\begin{array}{c}\text { project } \\
\%\end{array}$} & 1 & $\$$ & 5,522 & $\$$ & 5,522 \\
\hline Transmission [ne maintenance & & $3.0 \%$ & s & 225,000 & $s$ & 6,750 \\
\hline Parts and labour & \multirow{2}{*}{$\begin{array}{c}\text { kWh } \\
\text { project }\end{array}$} & $1,263,482$ & $\$$ & 0.015 & $\$$ & 18,952 \\
\hline GHG monitor and verification & & 1 & $\$$ & 1,500 & $\$$ & 1,500 \\
\hline Communitybenefits & \multirow{2}{*}{$\begin{array}{c}\text { project } \\
\text { p-tip }\end{array}$} & 1 & $\$$ & 10,000 & $\$$ & 10,000 \\
\hline Traveland accommodations & & 5 & $\$$ & 3,000 & $\$$ & 15,000 \\
\hline General and admin. & \multirow{2}{*}{$\begin{array}{l}\% \\
\%\end{array}$} & $20 \%$ & $\$$ & 57,724 & $\$$ & 11,545 \\
\hline Contingencies & & $10 \%$ & $\$$ & 69,269 & $\$$ & 6,927 \\
\hline \multicolumn{5}{|l|}{ AnnualCosts - Total } & $\$$ & 76,196 \\
\hline
\end{tabular}

Figure 4.2-20, US O\&M Costs from 2000-2007

\subsubsection{Project Feasibility Analysis}

The computer model used to analyze the potential projects is a Microsoft Excel-based program. The inputs to the model cover several different dimensions that describe the resources available for the projects. The inputs include:

1. Renewable energy resource attributes such as wind speed

2. Wind energy equipment characteristics including turbine type, number of turbines, expected energy delivered to the grid, etc.

3. Financial dimensions of the project such as project life, expected start and operational dates, purchase price for the energy and the RECs, discount rate, debt/equity ratio, operations and maintenance expenses, income and other taxes, development fees, inflation and cost increase rates, governmental renewable energy incentives, etc.

The results from the model calculation include:

1. The expected rate of return for the project

2. The levelized cost of energy (LCOE)

3. Financial pro formas such as sources and uses of funds, income statement, cash flow, depreciation, etc.

Feasibility analysis results were not included in this DOE-submitted final report due to confidentiality concerns related to ongoing development partner discussions.

Figure 4.2-21 Project Economic Analysis 


\subsubsection{Western Winnebago Interconnection}

The two electrical utilities that provide service to this area are:

- Nebraska Public Power District (NPPD)

- $\quad$ Northeast Nebraska Public Power District (NNPPD)

These two electrical utilities have transmission lines and substations located within reasonable distance of the wind farm site. Options include two substations, one owned by NPPD, and the other owned by NNPPD. Also, an NPPD $115 \mathrm{kV}$ transmission line is within roughly 3 miles east of the proposed project site, and an NPPD $345 \mathrm{kV}$ transmission line is adjacent to the southern border of the wind farm site.

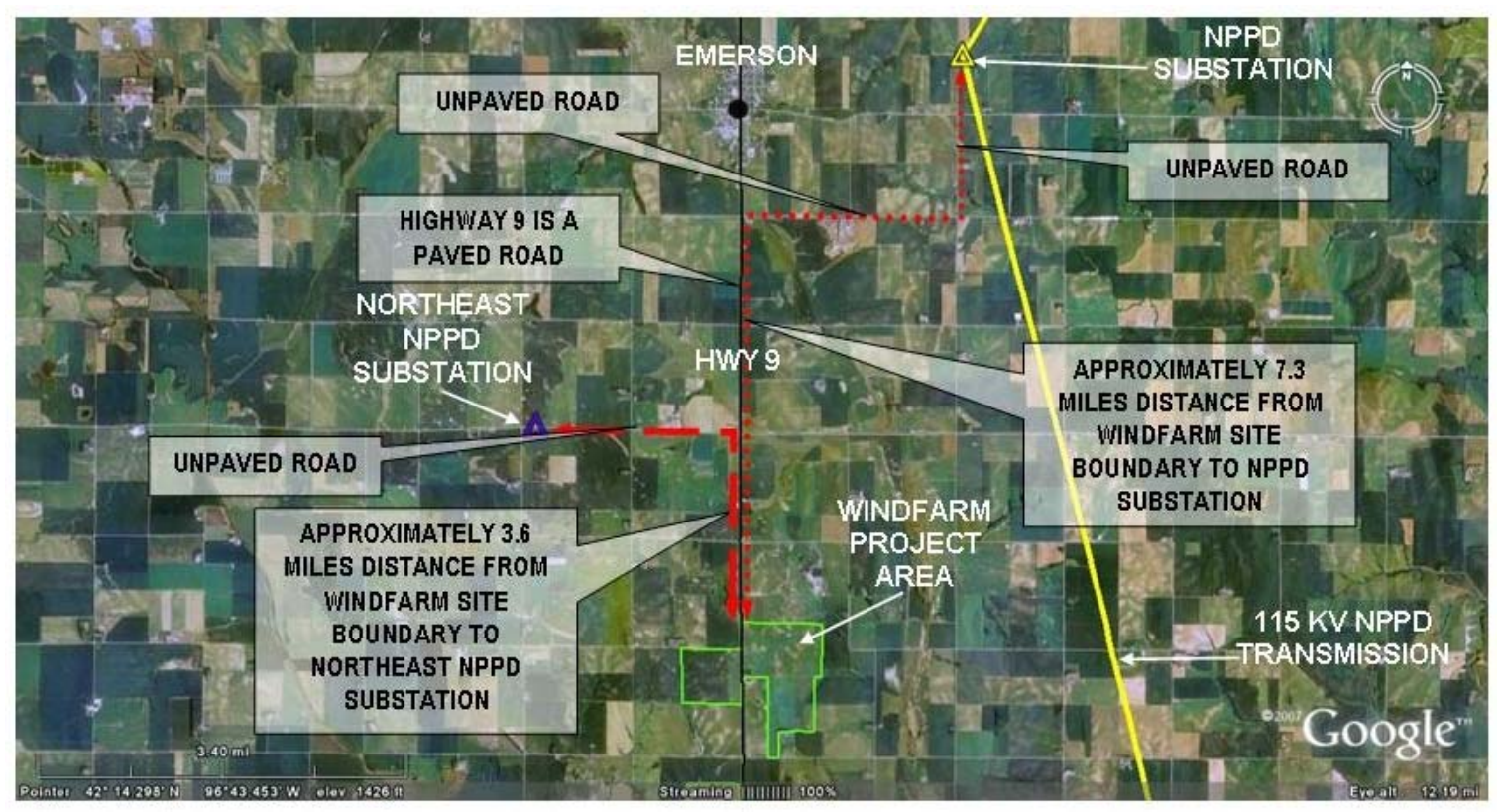

Figure 4.2-22, Western Winnebago Interconnection 1 


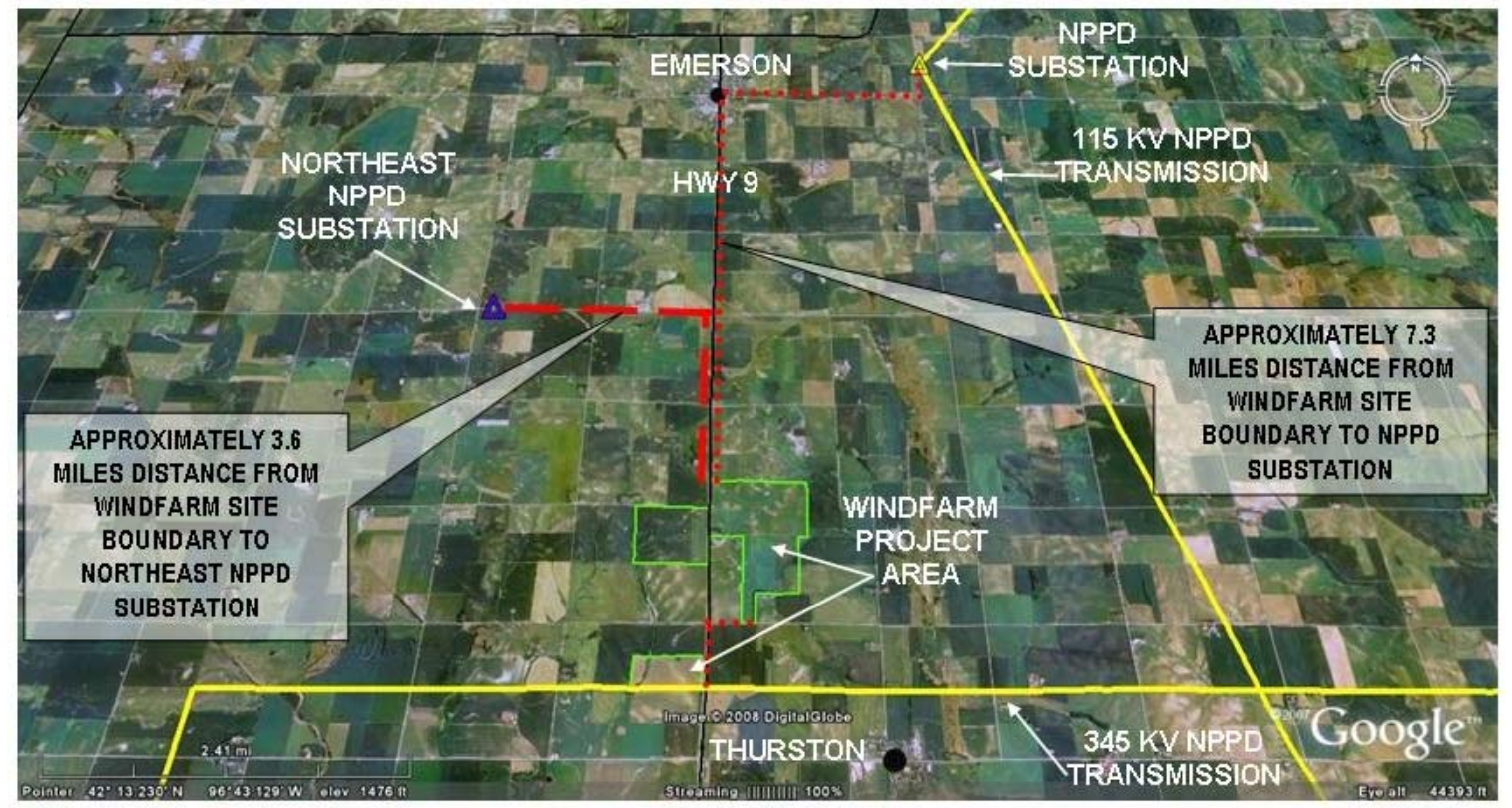

Figure 4.2-23, Western Winnebago Interconnection 2 


\subsection{Thunderway: Community-Scale Wind Project}

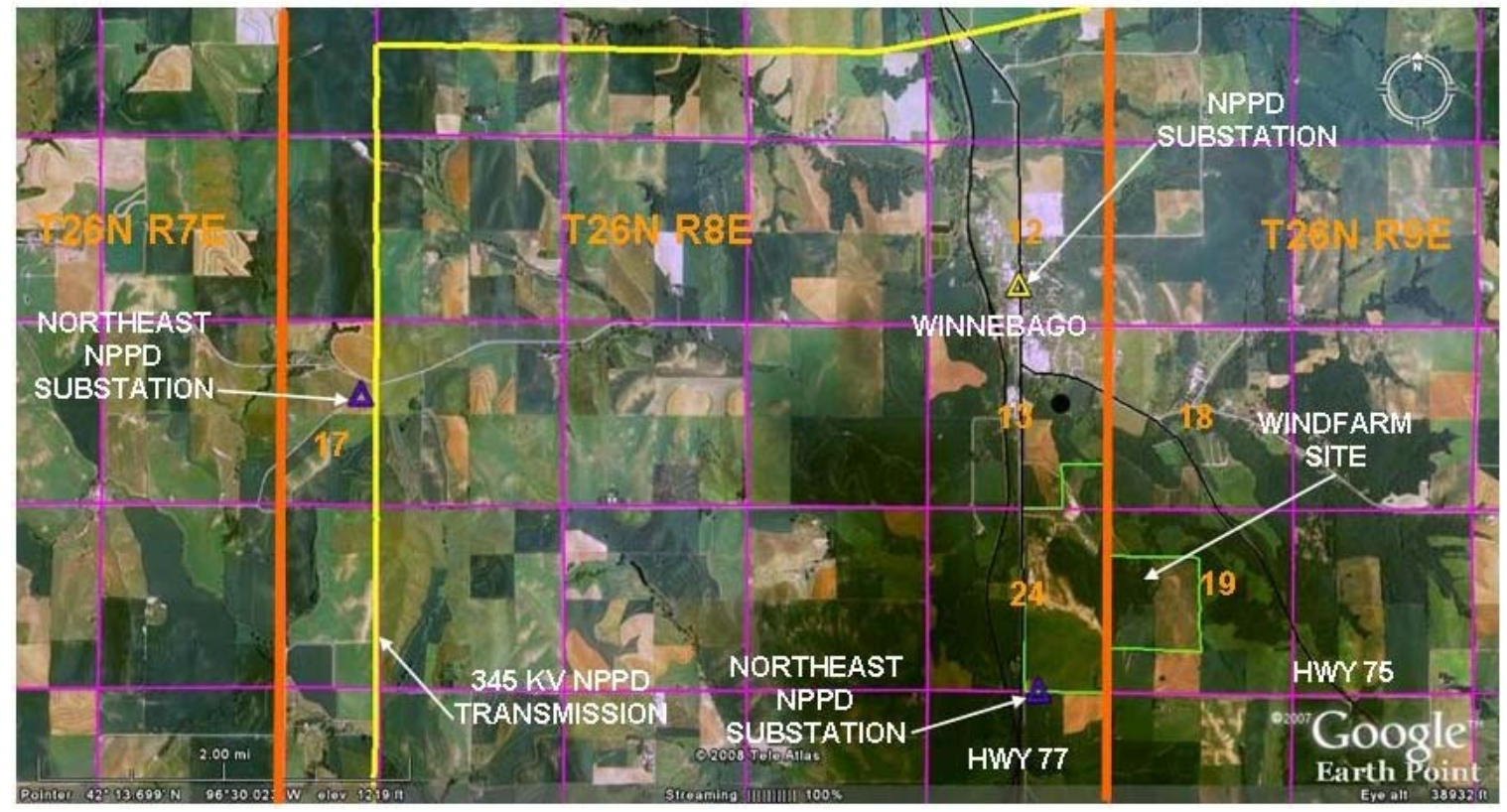

Figure 4.3-1, Thunderway Site Overview

The Thunderway Site is the primary community-scale project site for Winnebago (see Figure 4.3-1). The Thunderway Site is located in Sections 13 and 24 of the township and range T26N R8E and in Sections 18 and 19 of the township and range T26N R9E within the Nebraska State PLSS system (Public Land Survey System, NAD 83). The proposed windfarm project area to be utilized is comprised of a single contiguous area that covers 485 acres of trust land.

The project site area is characterized by sloping features and widely varying elevations. The area is topographically dominated by a large wooded hill. In terms of land use, the area is a mixed-use area including agricultural, light industrial and residential activity. A metal recycling yard and a Northeastern NPPD substation are both located within the project site boundaries near Highway 77. A tribal housing development of approximately 22 homes, Kelly Subdivision, is located on the project site. Also, a second tribal elderly housing development is currently under construction within the project site's boundary.

Figure 4.3-2 illustrates the locations and vantage points for the accompanying photos of the site. Also, Figure 4.3-2 identifies the existing Kelly Subdivision of 22 homes, water tank, woods, and metal recycling yard also on site. 


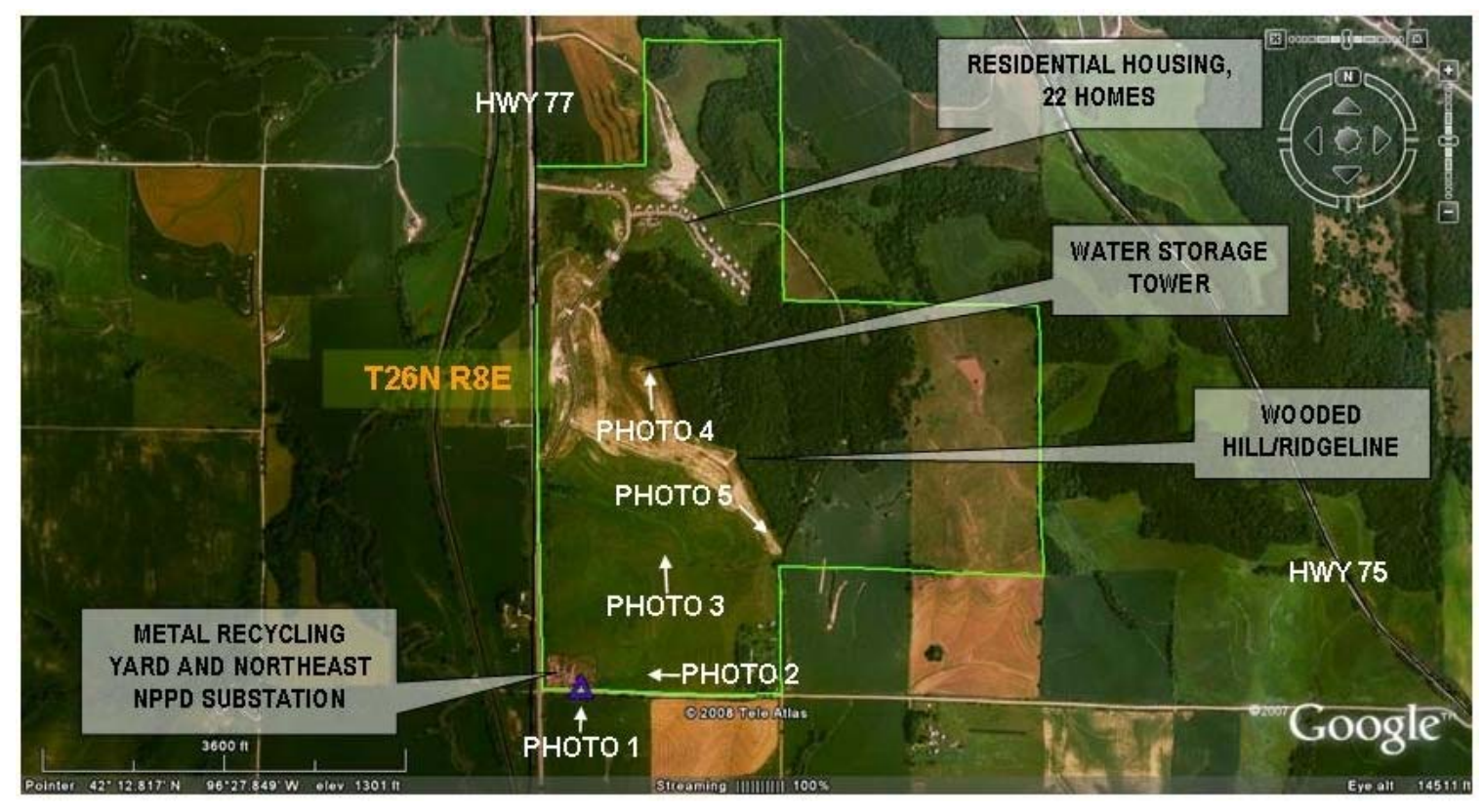

Figure 4.3-2, Thunderway Photo Vantage Points

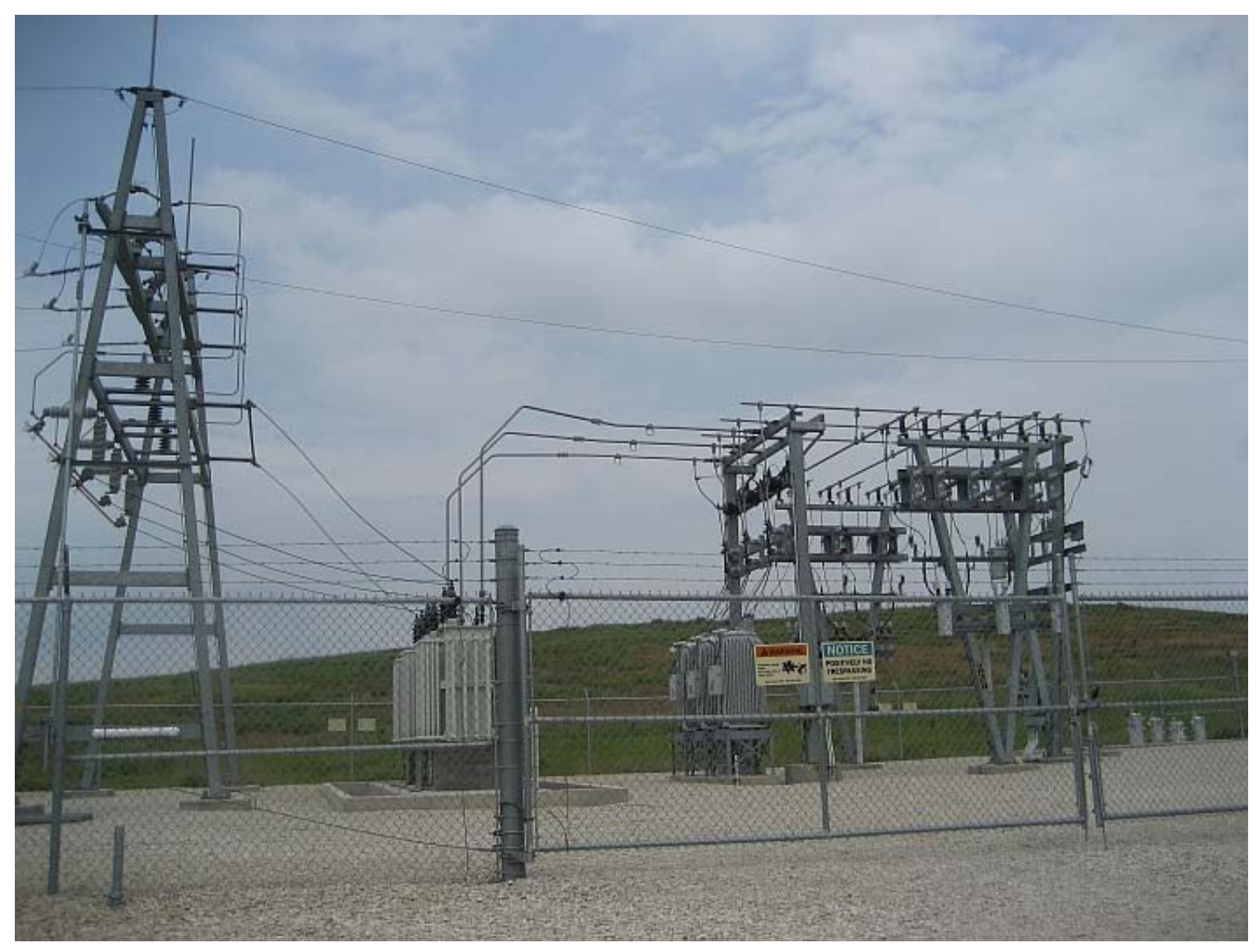

Figure 4.3-3, Looking North to Substation 


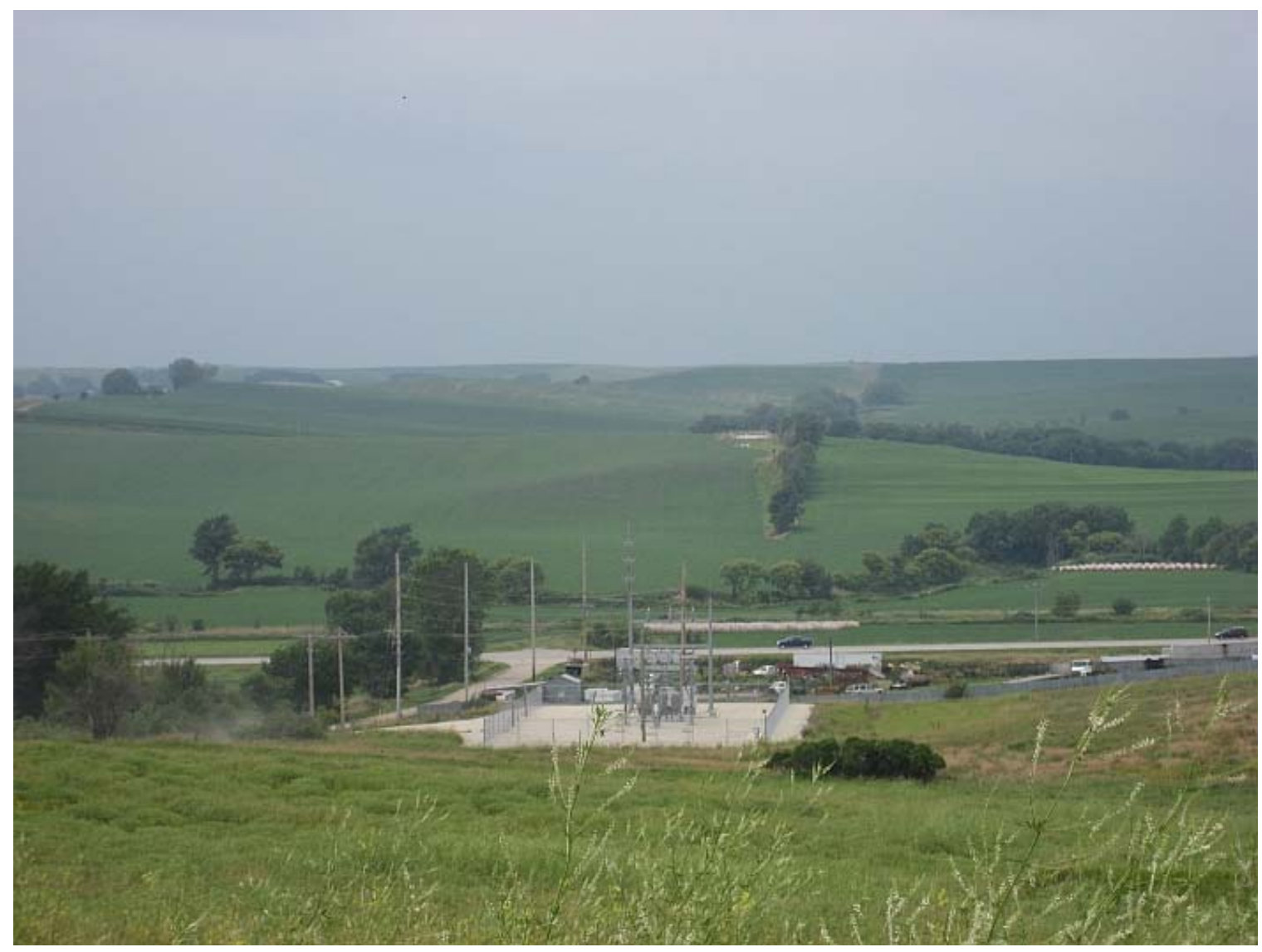

Figure 4.3-4, Looking West Toward Substation

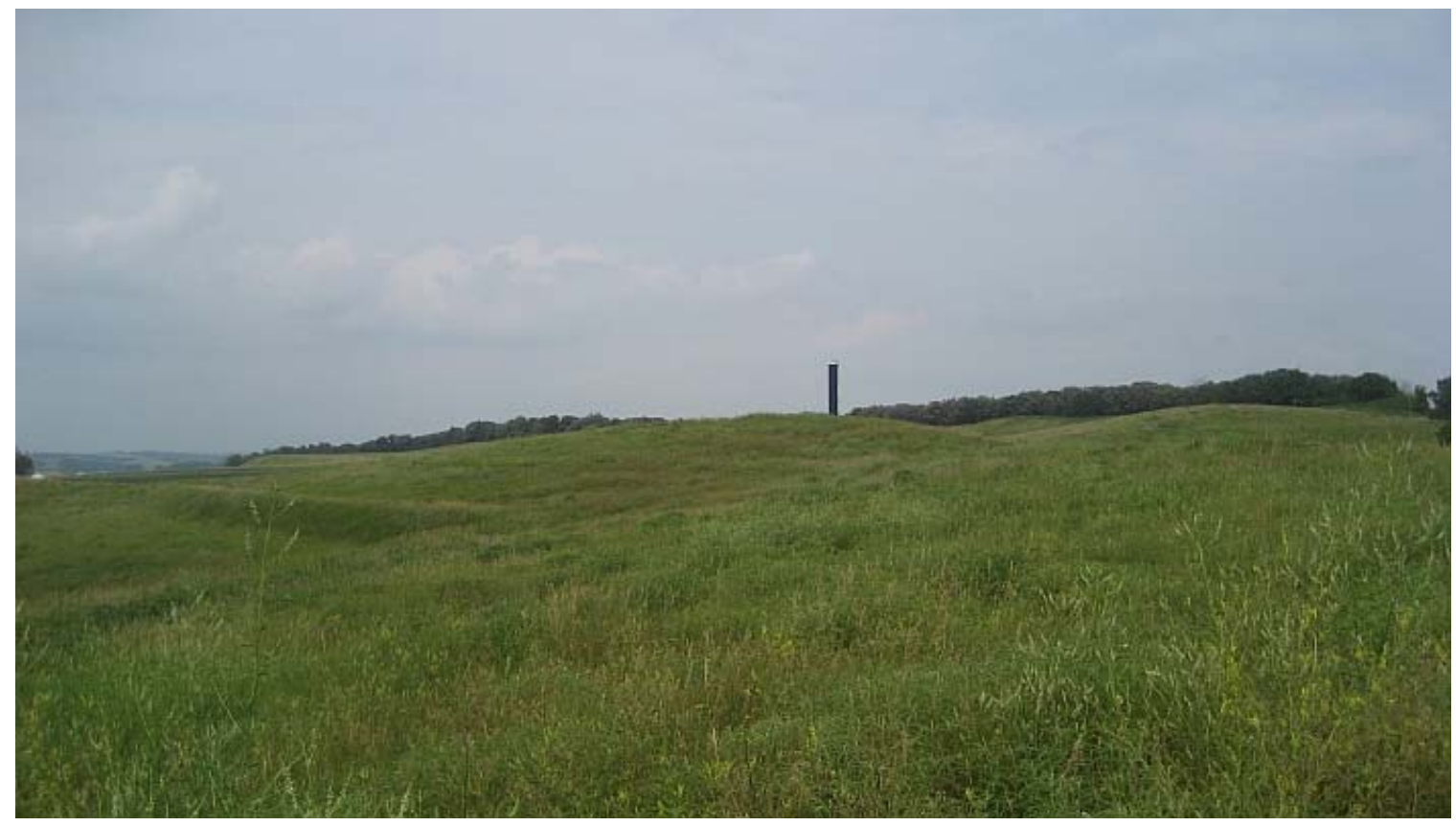

Figure 4.3-5, Looking North Toward Water Tower Storage 


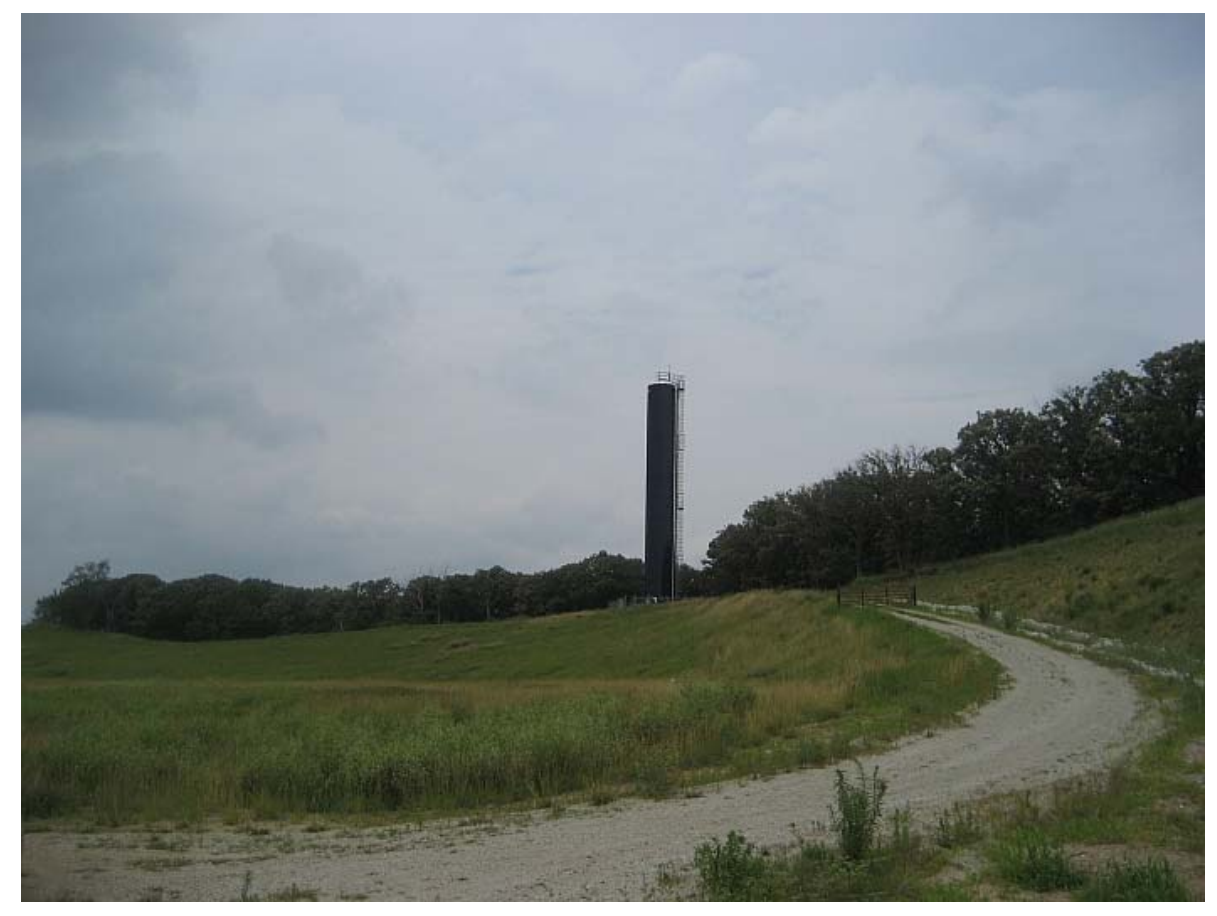

Figure 4.3-6, Looking North Toward Water Storage

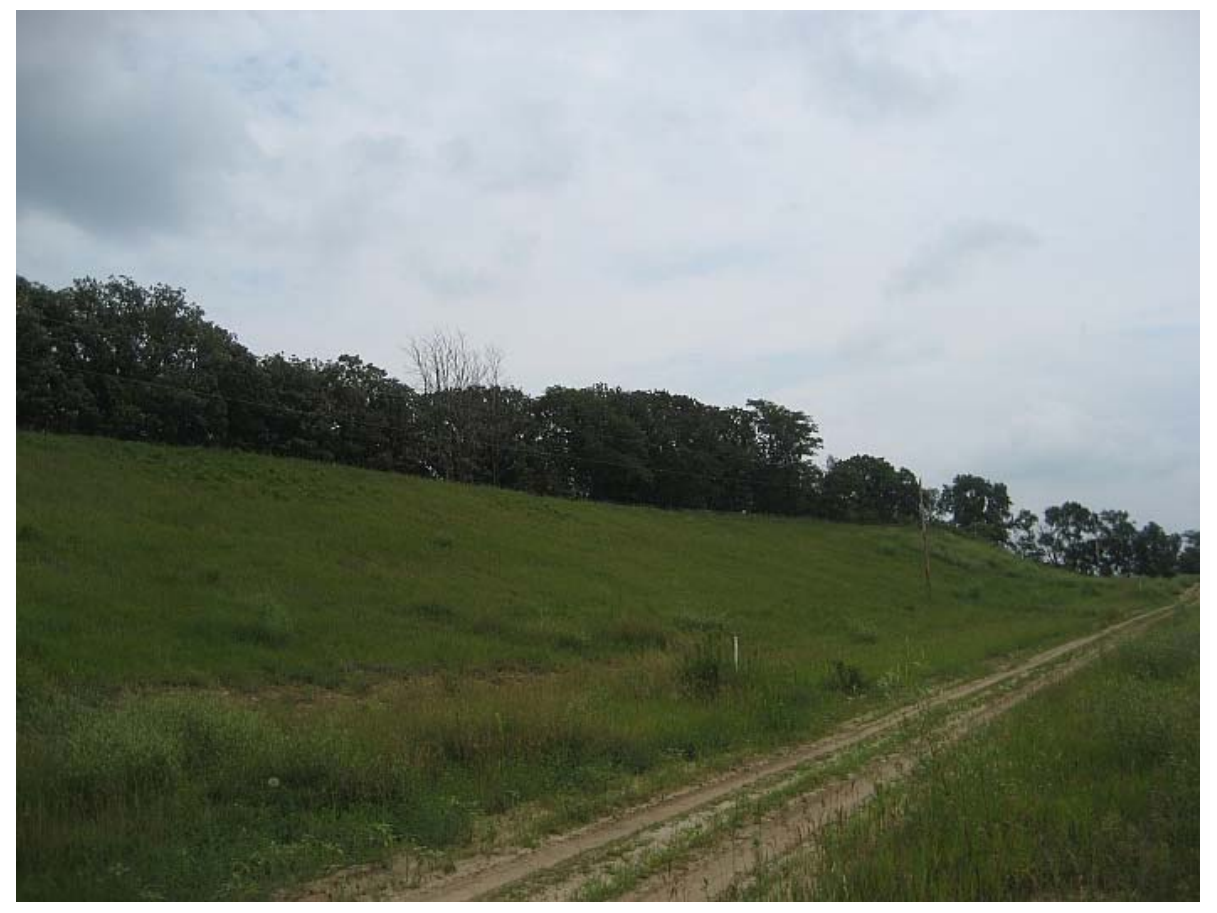

Figure 4.3-7, Looking Southeast Toward Ridgeline

There are currently restrictions for land use in Section 1 (31.1 acres) and Section 5. A commitment to the Department of Agriculture Conservation Reserve Program (CRP) is expected to expire in September 30, 2013. The design includes the CRP lands for wind farm development and assumes that 
the turbines will be installed on these locations after the CRP program expires, or with US Department of Agriculture approval.

\subsubsection{Wind Resource Assessment}

The Windlogics map indicates commercial-scale winds to be present at the Thunderway Site as shown in Figure 4.3-1. According to Windlogics, wind speeds are in the $17.3 \mathrm{mph}$ range at 80 -meter hub height. This wind speed would be sufficient for wind farm development.

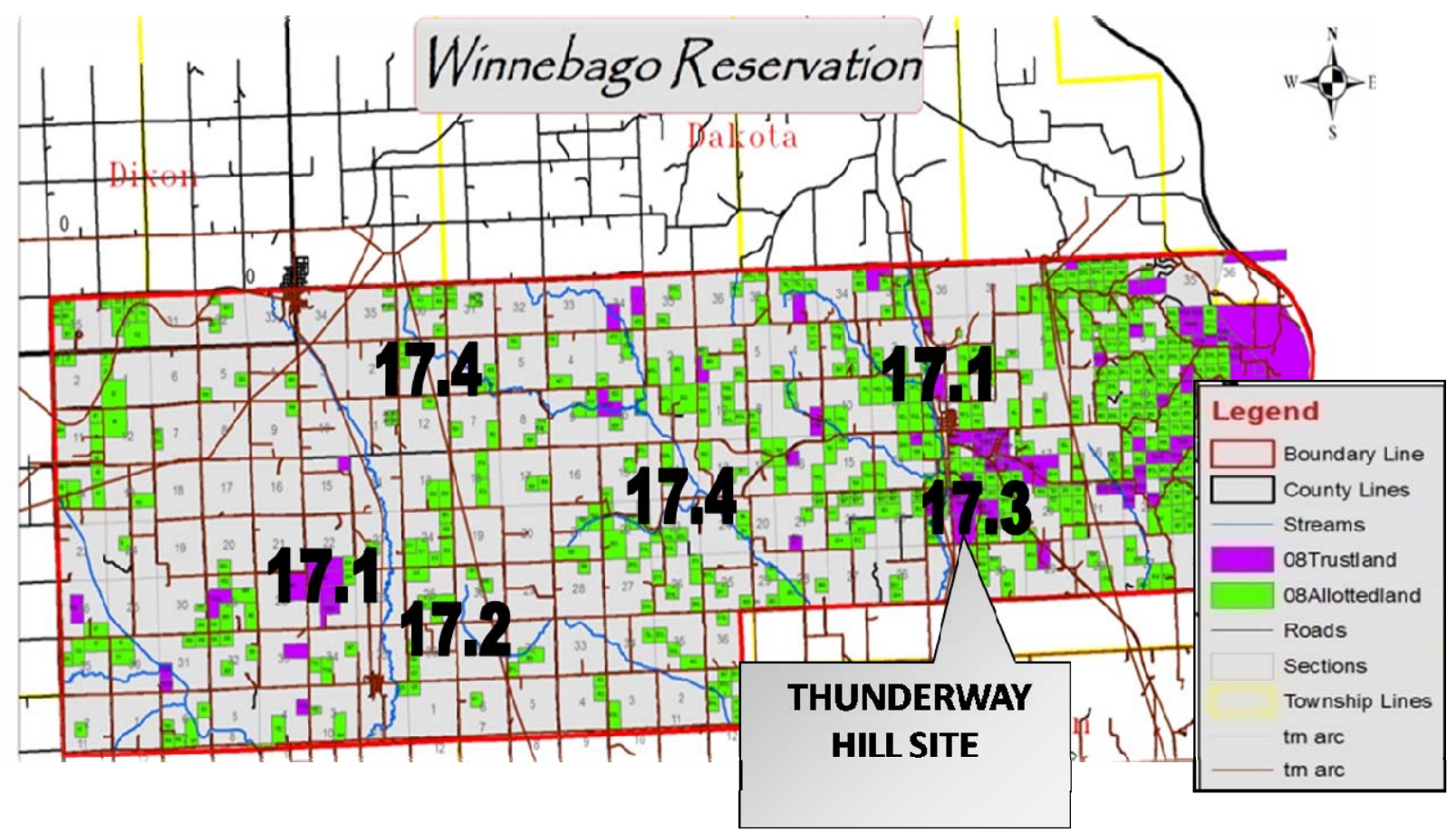

Figure 4.3-1, Thunderway Wind Resource Map

Burt County Public Power District distribution lines serve the area, and a Northeast Nebraska Public Power substation is located approximately one mile away from the nearest potential wind turbine installation site. Thunderway is located on Route 77, a major highway that provides sufficient access during the installation. 


\subsubsection{Project Layout and Design}

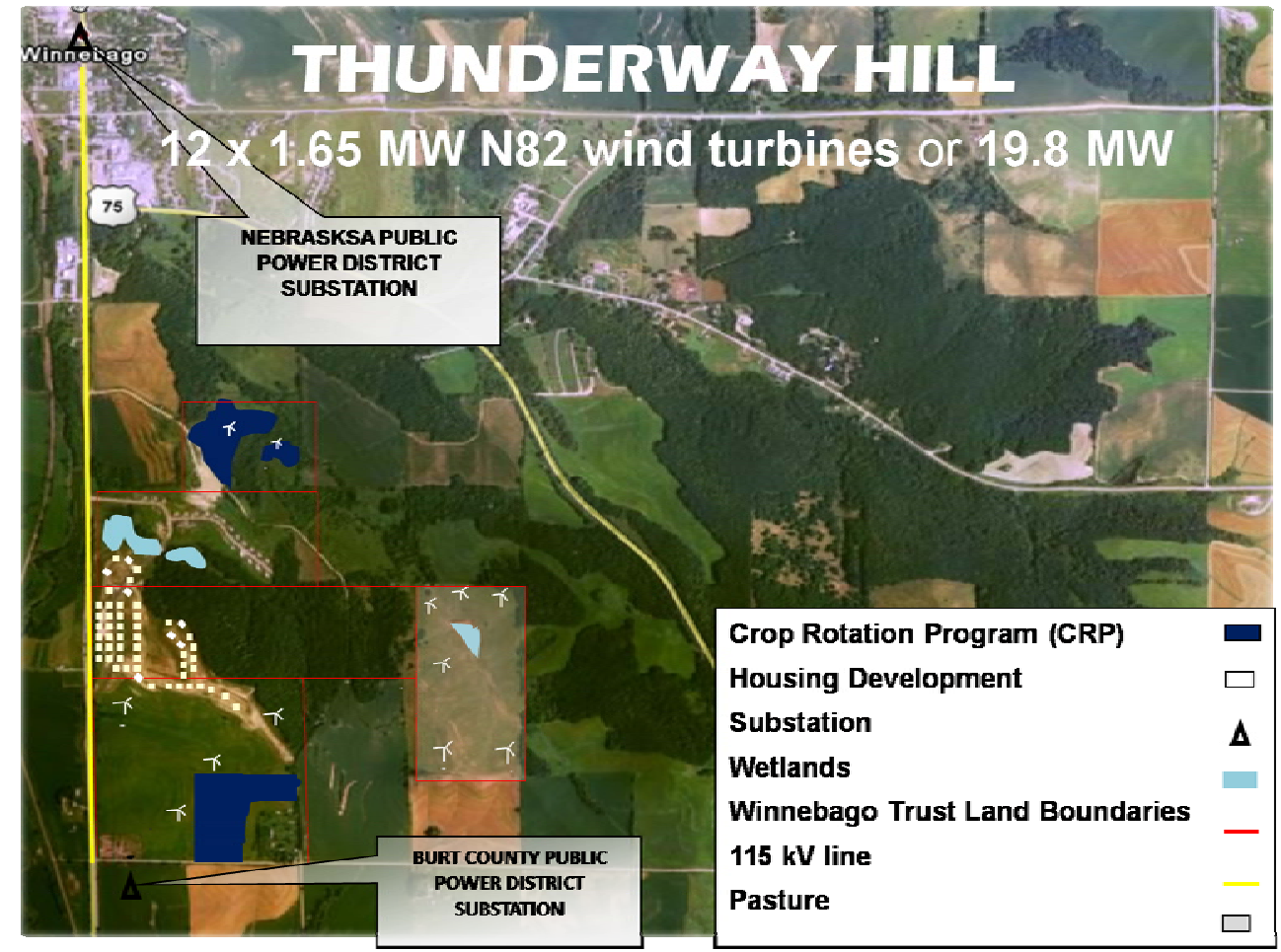

Figure 4.3.2, 19.8MW Layout Design

Figure 4.3-2 illustrates a potential turbine layout for a $19.8 \mathrm{MW}$ windfarm. This figure also highlights the CRP, housing development and wetlands areas. This configuration allows for approximately 12 1.65MW turbines.

Figure 4.3-3 is the contour map for the Thunderway Site. The elevations for the Thunderway Site are between 1,150 - 1,312 feet for this area. Figure 4.3-4 displays Sections 1 and 2 and illustrates the distances from housing units. Figure 4.3-5 is the Section 3 layout of 6 turbines. All turbines are more than 600 feet from the wetlands in the middle of the section. Finally, Figure 4.3-6 contains the layout for Section 5 where less than $1 / 4$ of the section is under the CRP program. 


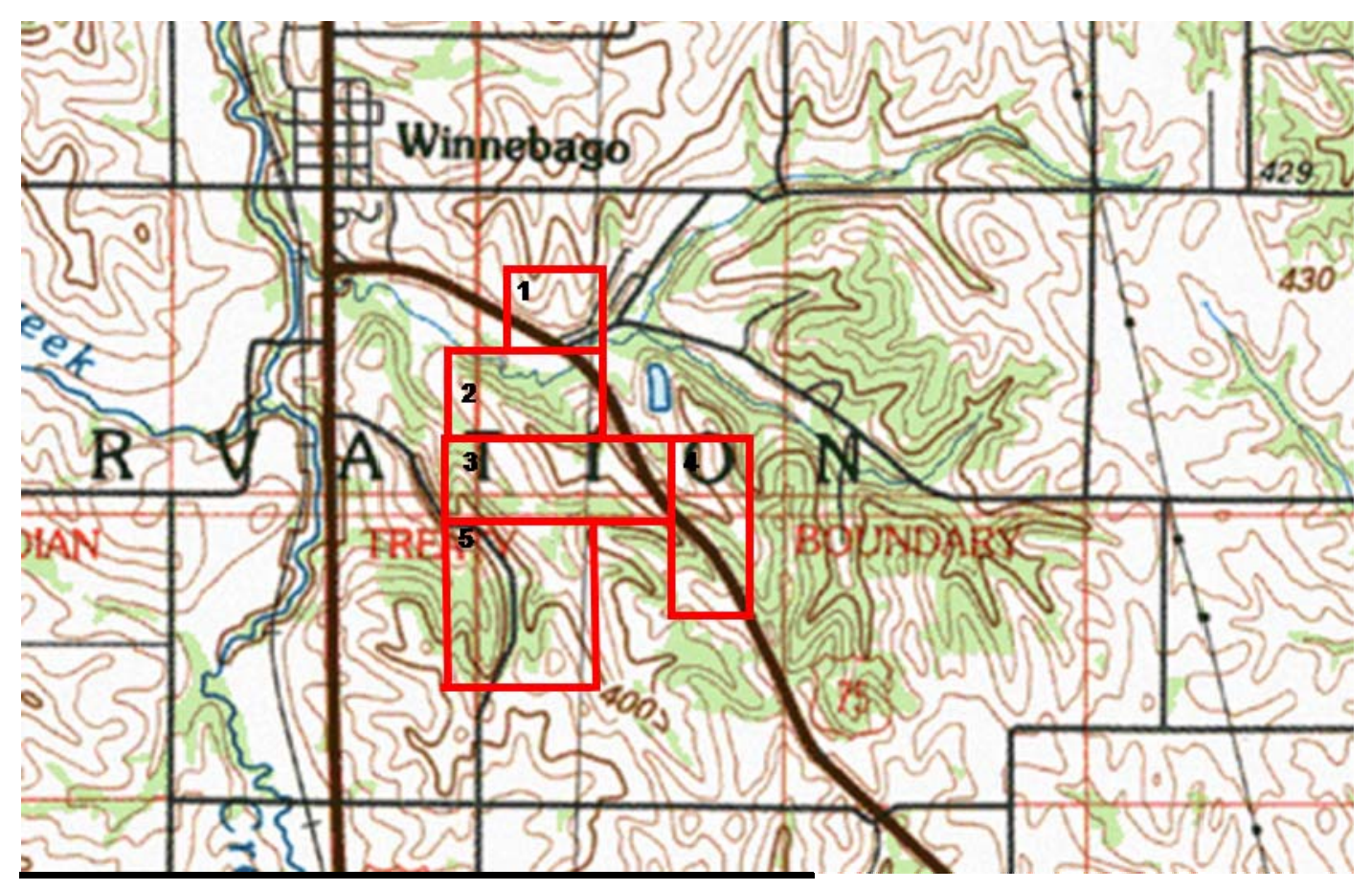

Figure 4.3-3, Thunderway Topo Map

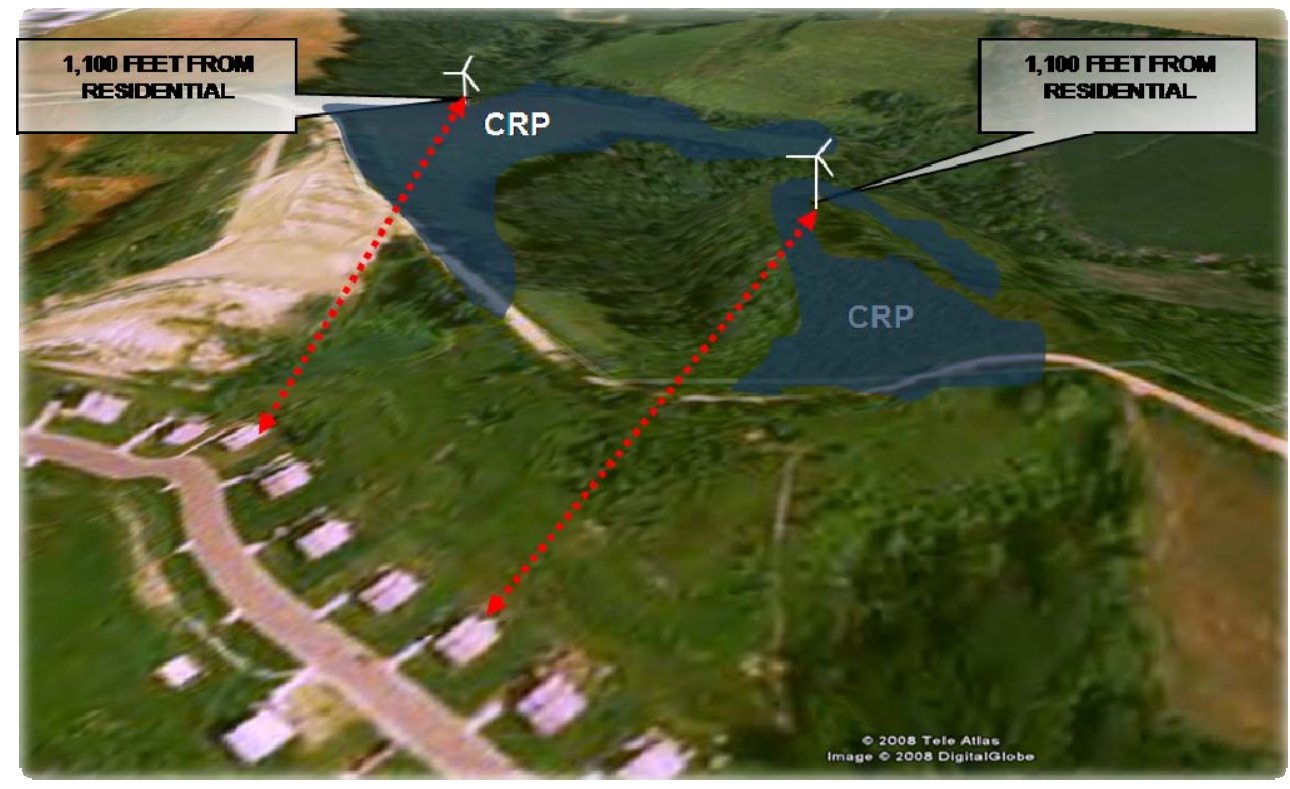

Figure 4.3-4, Thunderway CRP, Sections 1 and 2 


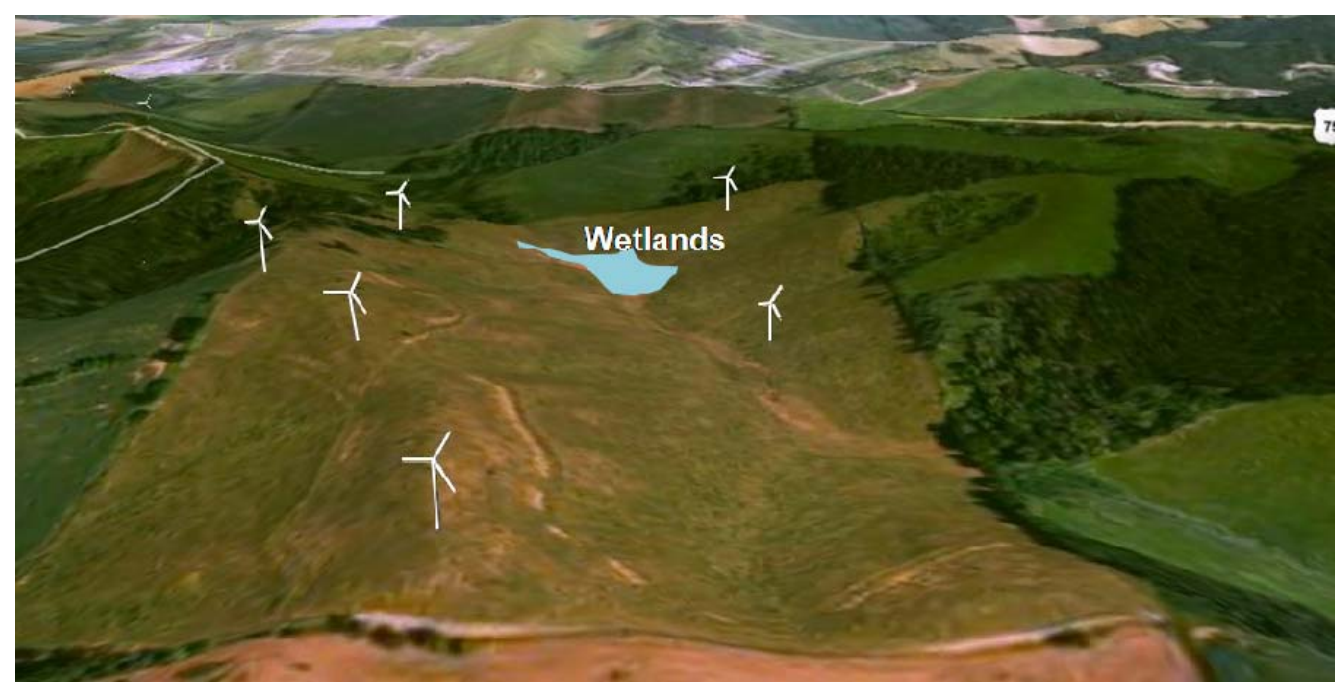

Figure 4.3-5, Thunderway Wetlands, Section 3

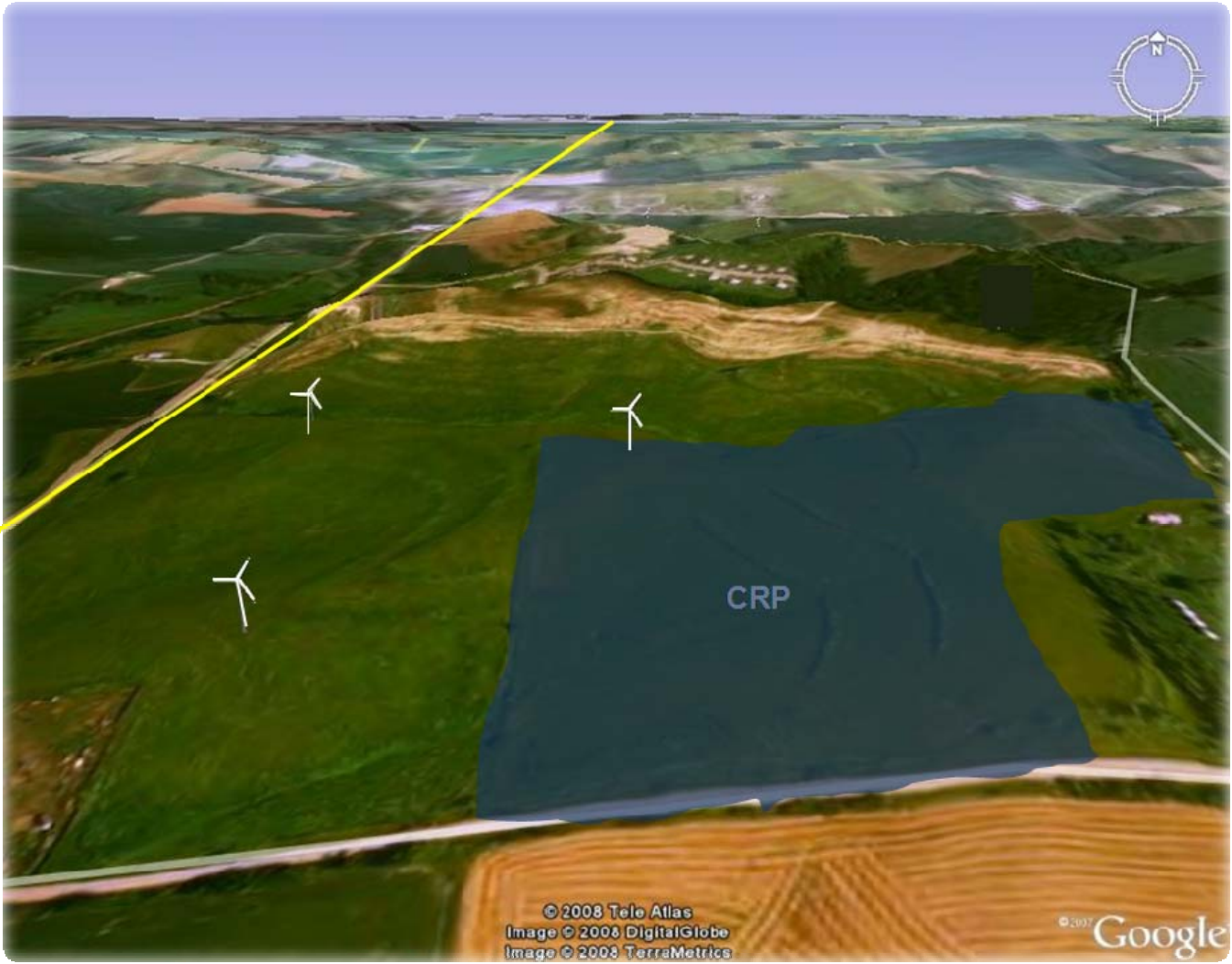

Figure 4.3-6, Thunderway Section 5 


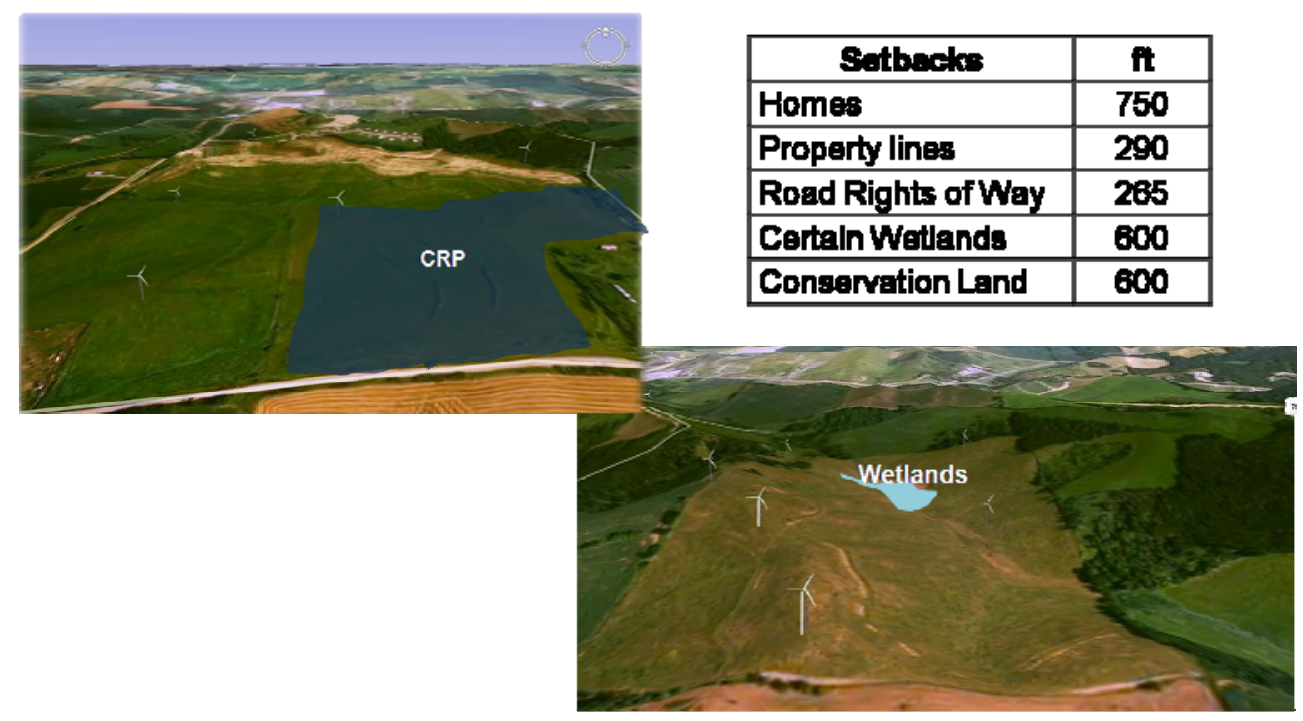

Figure 4.3-7, Thunderway Setbacks Summary

\subsubsection{Wind Production and Project Cost Analysis}

The 50-meter met tower provided through the NREL program, previously in place at the WinnaVegas Casino, blew down during installation at the Thunderway site, and was damaged. Replacement parts have been ordered, but as of the finalization of this report, had not yet been received. For that reason, wind production was calculated based on the projected wind speeds at the site as shown in Figure 4.38. Energy production and capacity factors were initially calculated based on use of Vestas N82 1.65 MW turbines. Under that assumption, a $19.8 \mathrm{MW}$ wind farm at Thunderway would generate 54,075,813 $\mathrm{kWh}$ and have a capacity factor of $31.9 \%$.

\begin{tabular}{|c|c|c|c|}
\hline Site Description & $\begin{array}{c}\text { Project } \\
\text { Size } \\
\text { MW }\end{array}$ & $\begin{array}{c}\text { Average } \\
\text { Wind Speed } \\
\mathbf{9 8 0} \mathbf{m}, \mathbf{m p h}\end{array}$ & $\begin{array}{c}\text { Average Total } \\
\text { Annual Energy } \\
\text { kWh }\end{array}$ \\
\hline Thunderway Hill & 19.8 & 17.3 & $54,075,813$ \\
\hline
\end{tabular}

Figure 4.3-8, Thunderway Energy Production

Capital costs were estimated for the wind project in a manner similar to that used in the Western Winnebago analysis. Later analyses were also completed assuming use of GE 1.5 xle turbines. Projected cost and production estimate comparisons are summarized in Figure 4.3-9. 


\begin{tabular}{|lll|}
\multicolumn{1}{|c|}{ Attribute } & \multicolumn{1}{c|}{ GE 1.5xle } & \multicolumn{1}{c|}{ Vestas N82 } \\
\hline Wind speed $(\mathrm{m} / \mathrm{s})$ & 7.73 & 7.73 \\
\hline Turbine power rating $(\mathrm{kW})$ & 1500 & 1650 \\
\hline Capacity installed (MW) (12 turbines at site) & 33 & 36.9 \\
\hline Turbine price (\$) (incl. tower \& erection) & $\$ 2,100,000$ & $\$ 2,128,500$ \\
\hline Availability (\%) & $97 \%$ & $97 \%$ \\
\hline Net Capacity Factor (\%) & $45 \%$ & $32 \%$ \\
\hline Total Annual Production to meter (MWh) & 69,203 & 59,942 \\
\hline Project Life (years) & 25 & 25 \\
\hline
\end{tabular}

Figure 4.3-9, Thunderway Wind Farm Estimated Cost and Production Comparison

\subsubsection{Project Feasibility Analysis}

Project economics were analyzed utilizing the same Excel-based model as described previously in section 4.2.6.

Feasibility analysis results were not included in this DOE-submitted final report due to confidentiality concerns related to ongoing development partner discussions.

Figure 4.3-10, Project Economic Analysis

\subsubsection{Thunderway Interconnection}

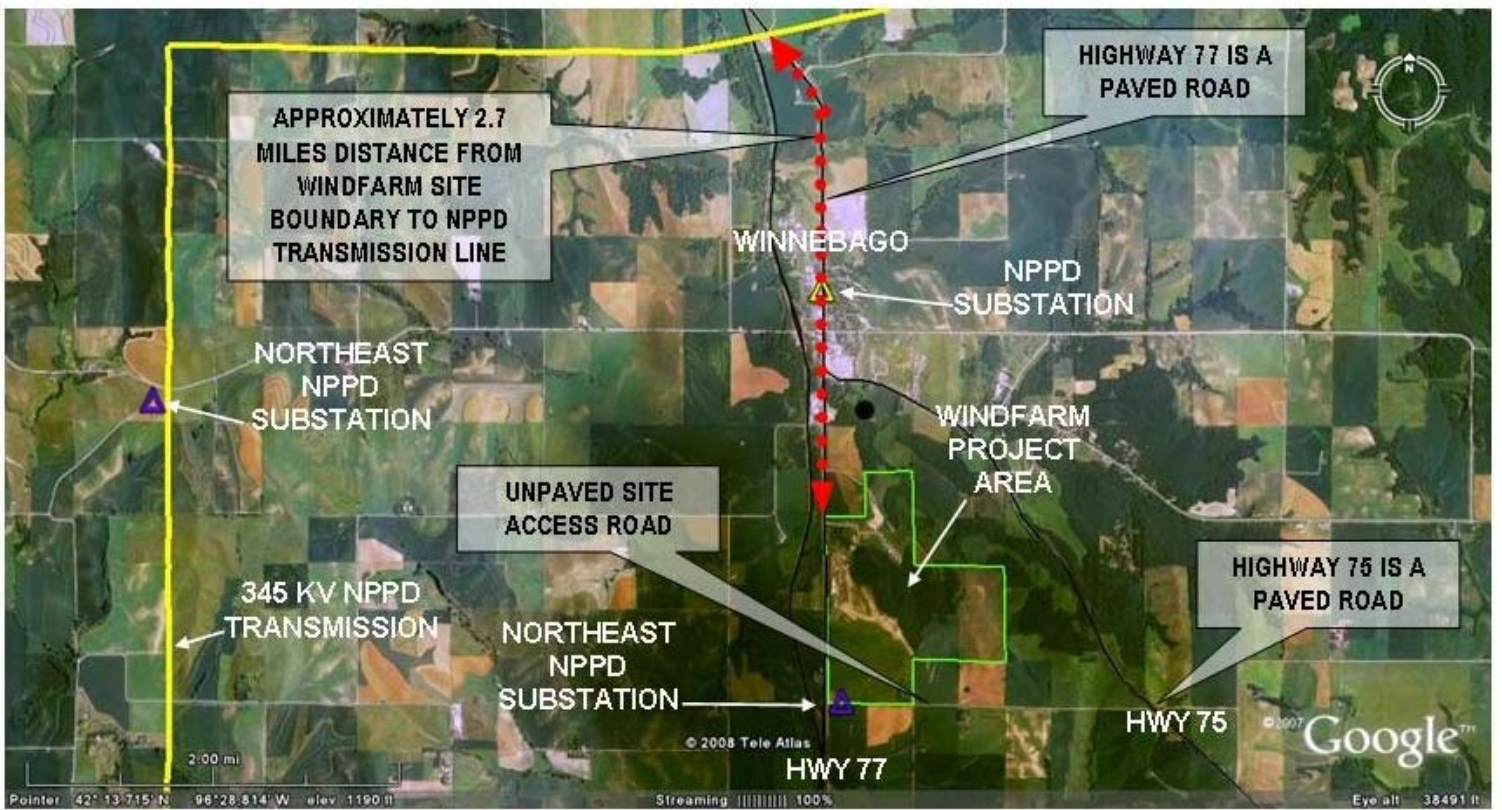

Figure 4.3 -11, Thunderway Interconnection 1 


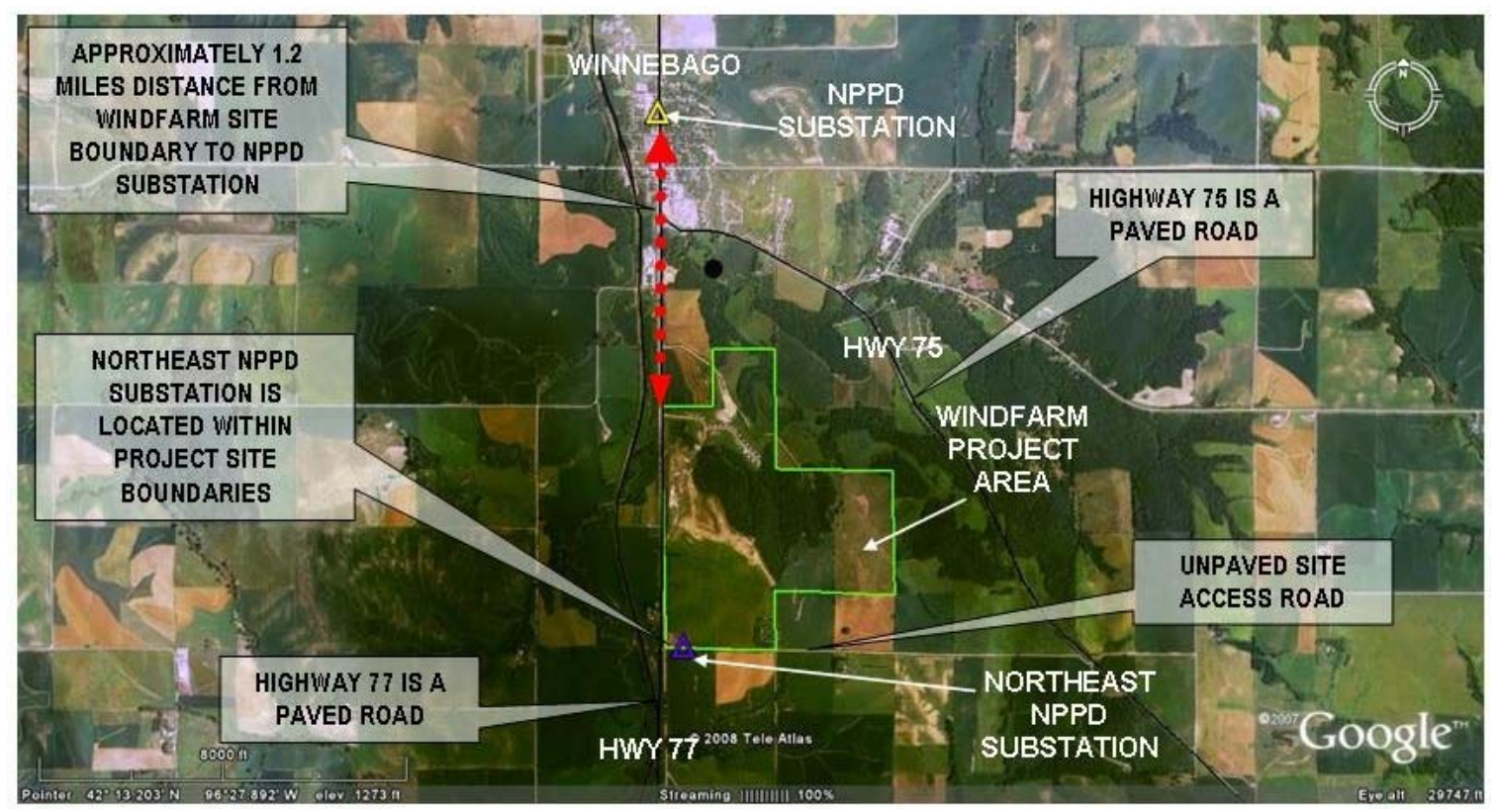

Figure 4.3-12, Thunderway Interconnection 2

Interconnection options include two nearby substations - one is NPPD's, and the other is owned by NNPPD. No further analysis of interconnection costs was completed at this time.

\subsection{Resource Impact and Protection}

\subsection{Environmental - Threatened or Endangered Species and Habitat}

The Nebraska Game and Parks Commission conducted a preliminary assessment for endangered species and bird migratory paths for the wind sites identified in the previous sections. This assessment does not satisfy requirements of the Nongame and Endangered Species Conservation Act. The following is a summary of results. The full report is found in the Appendix. In both Central and Western Winnebago there were no records of state-listed or candidates for threatened or endangered species on, or in the immediate vicinity.

Central Winnebago has areas of dense deciduous forest. This may provide habitat for birds during migration and for summer nesting. This location is east of the major Missouri River Migration Corridor and is not contiguous with other similar habitat. However, this site may provide habitat for breeding migratory birds, particularly migrating passerine and raptor species. These birds are protected under the Migratory Bird Treaty Act. This site could potentially have high seasonal concentrations of migrating birds.

The Western Winnebago site is primarily agriculture and rangeland, therefore a limited habitat for migratory birds is expected.

The northern long-eared myotis (Myotis septentrionalis) was recorded in the vicinity of both sites. This species is typically associated with forested areas. 
NE Game and Parks recommend an average of three years monitoring to determine peak use dates for migration. Consideration should be given for monitoring migration and bat activity both before and after construction. The Commission can assist with developing a monitoring plan.

Additional recommendations from the Commission include configuring turbine arrays to avoid potential avian mortality where feasible. For example, grouping turbines rather than spreading them widely, and orienting rows of turbines parallel to known bird movements to reduce potential bird strikes are possible strategies. In addition, implementing appropriate storm water management practices that do not create attractions for birds, maintaining continuous habitat for area-sensitive species, and minimizing roads, fences and other infrastructure are other options.

\subsection{Environmental- Wetlands and Protected Areas}

Figure 5.2-1 contains a map of wetlands in or near the Western Winnebago Site. Figure 5.2-2 also shows sensitive wetland areas that must be taken into account. Figure 5.2-3 shows wetland areas in the Thunderway Site. Also of importance is a requirement that turbine placement must be set back at least $600 \mathrm{ft}$ from any wetland area.

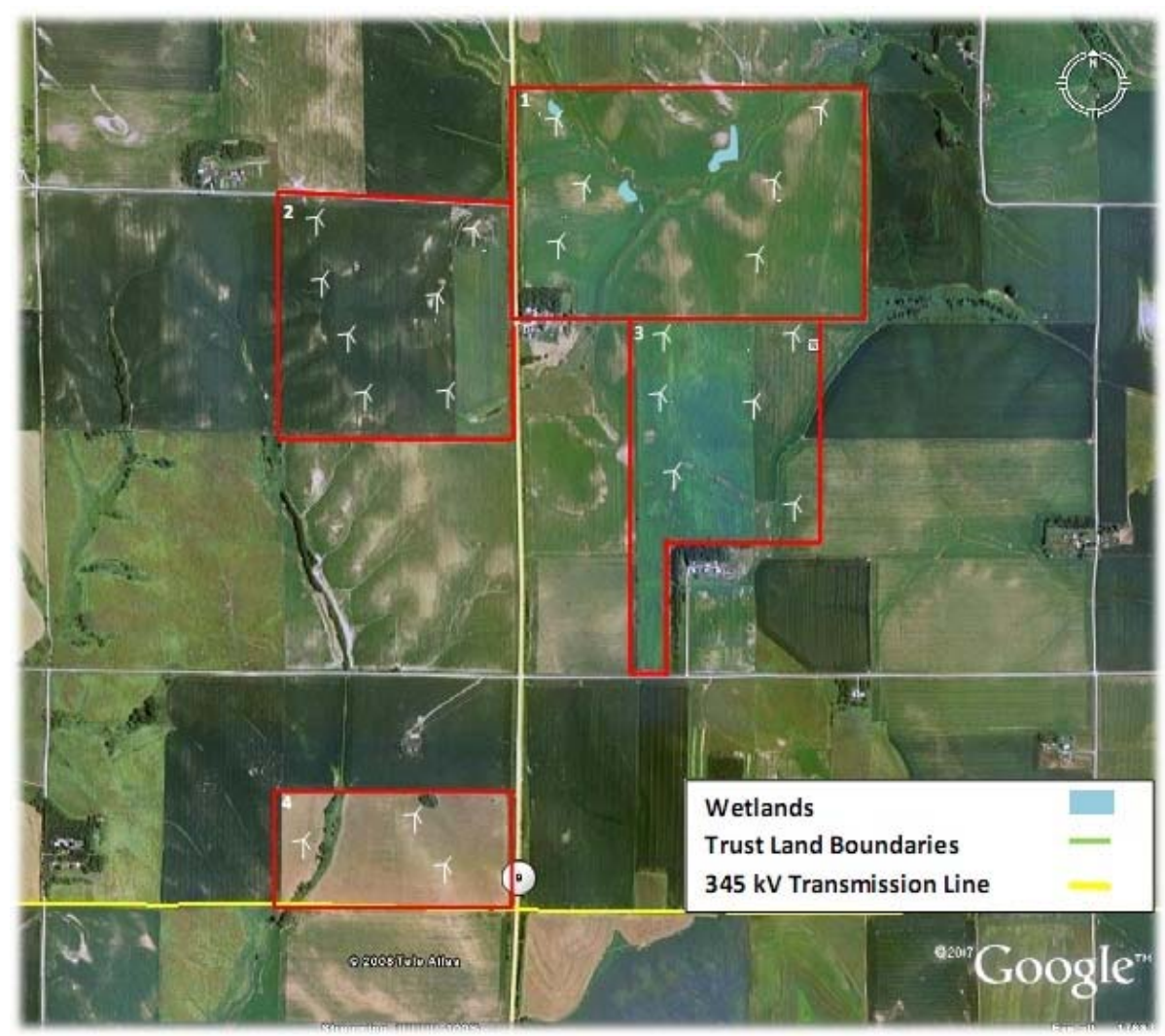

Figure 5.2-1, Western Winnebago Wetlands 1 


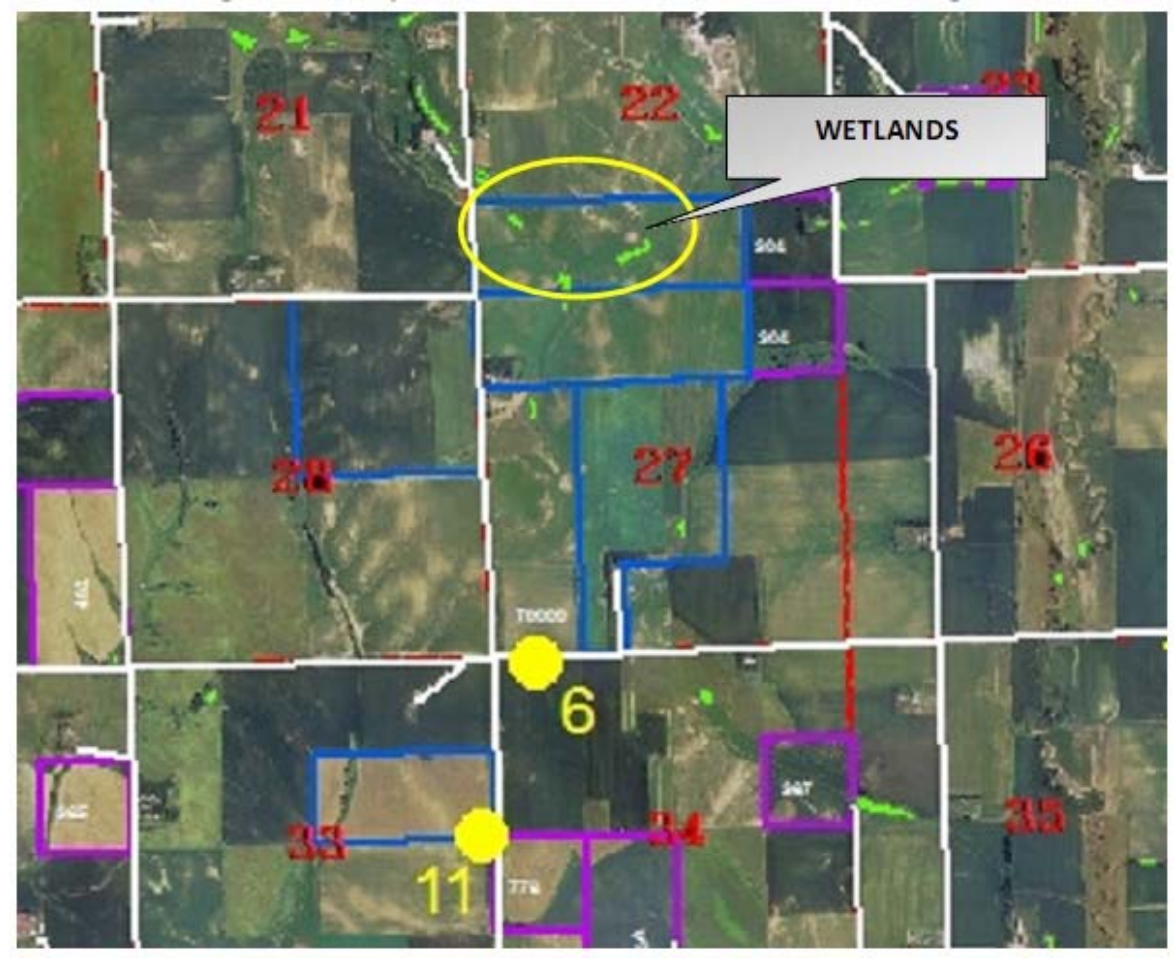

Figure 5.2-2, Western Winnebago Wetlands 2

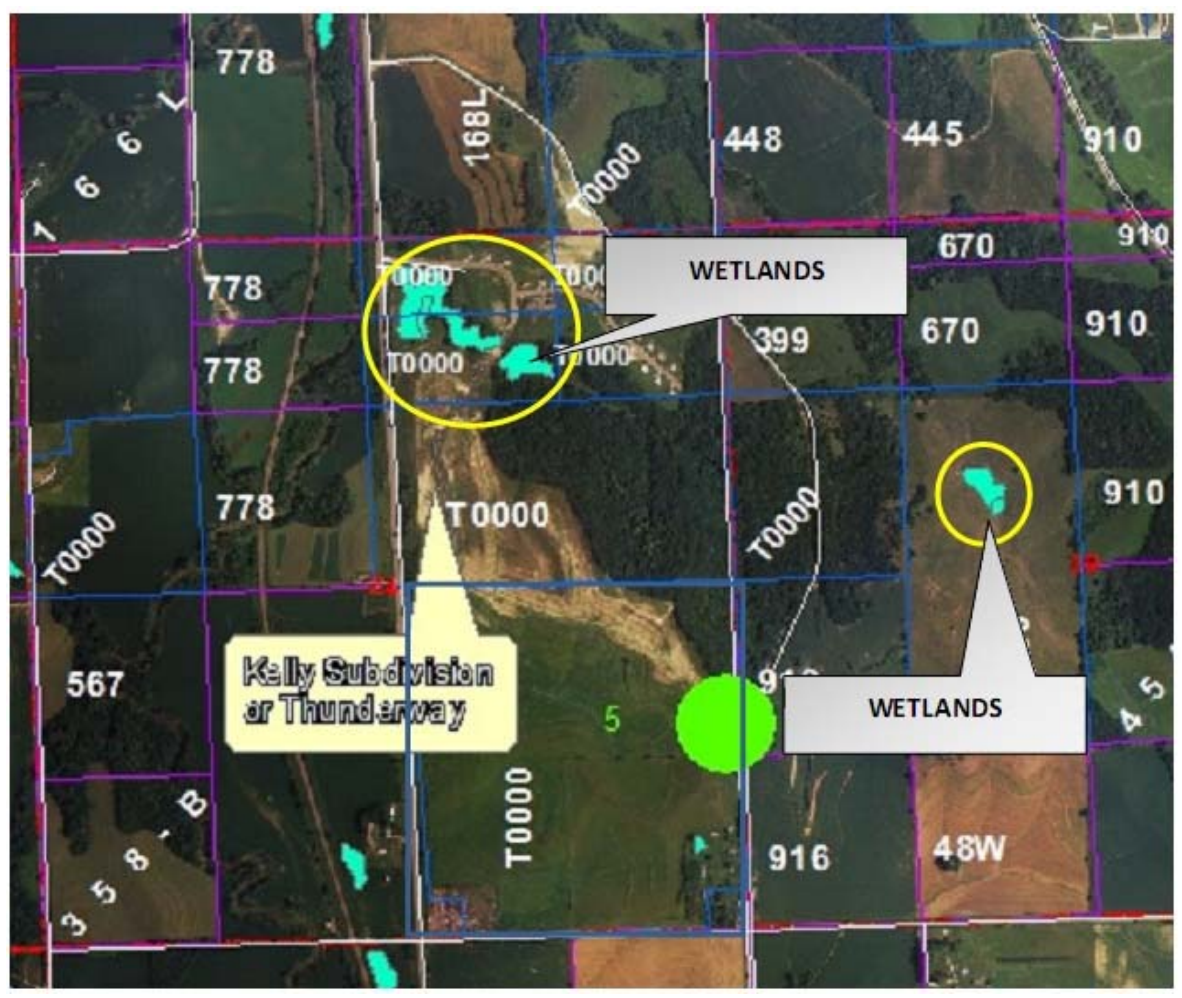

Figure 5.2-3, Thunderway Wetlands 


\subsection{Environmental- Visual Impacts}

A visual impact assessment was conducted on both wind sites identified. At Thunderway, there are approximately 22 homes nearby. Figure 5.3-1 thru Figure 5.3-6 show pre- and post-construction pictures for areas surrounding the Kelly housing subdivision. Some visual impacts will exist, given that almost all twelve turbines will be visible from the homes. In addition, this area includes future housing development plans.

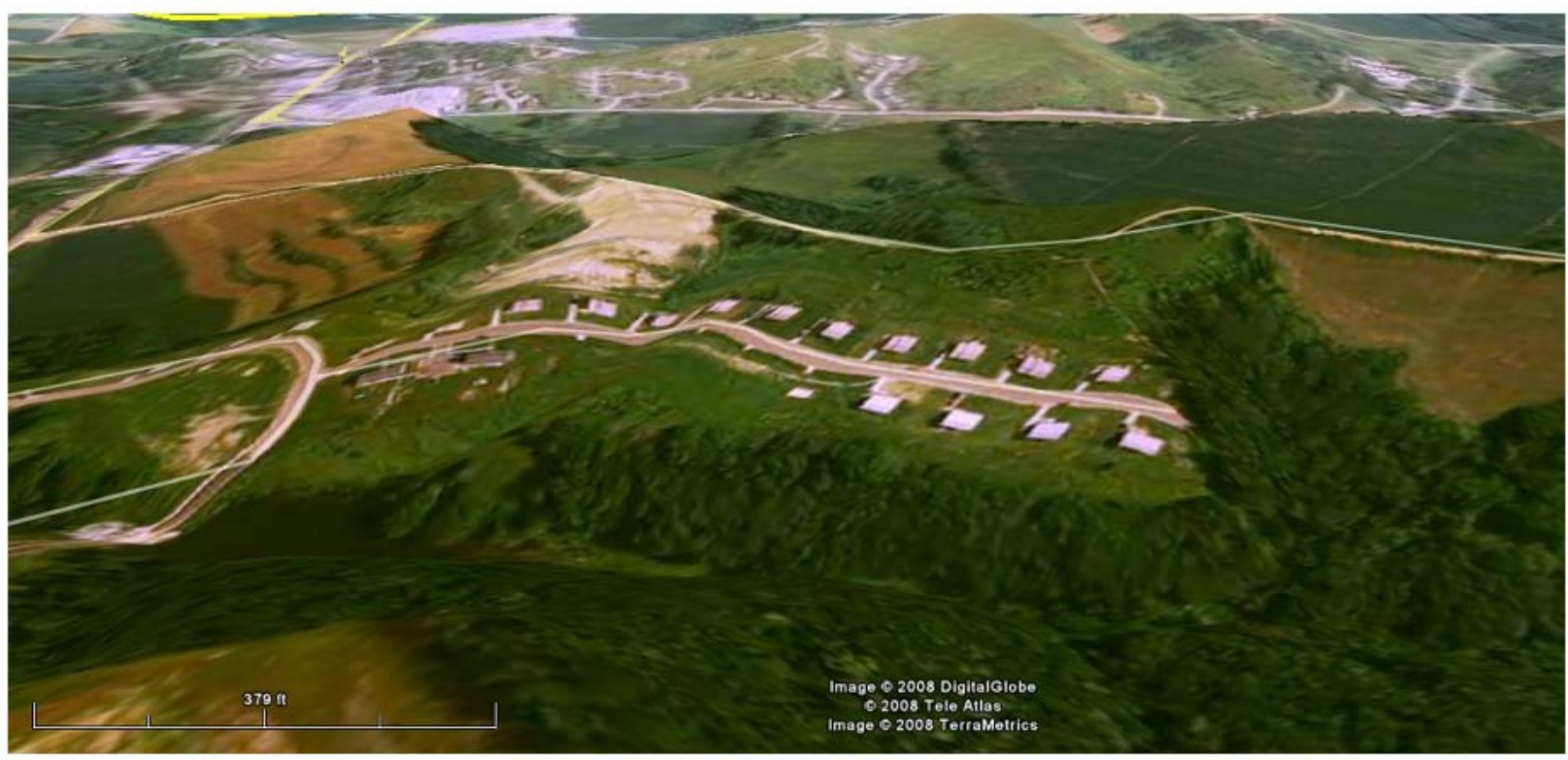

Figure 5.3-1, Kelly Subdivision, Northern View, Pre-Construction

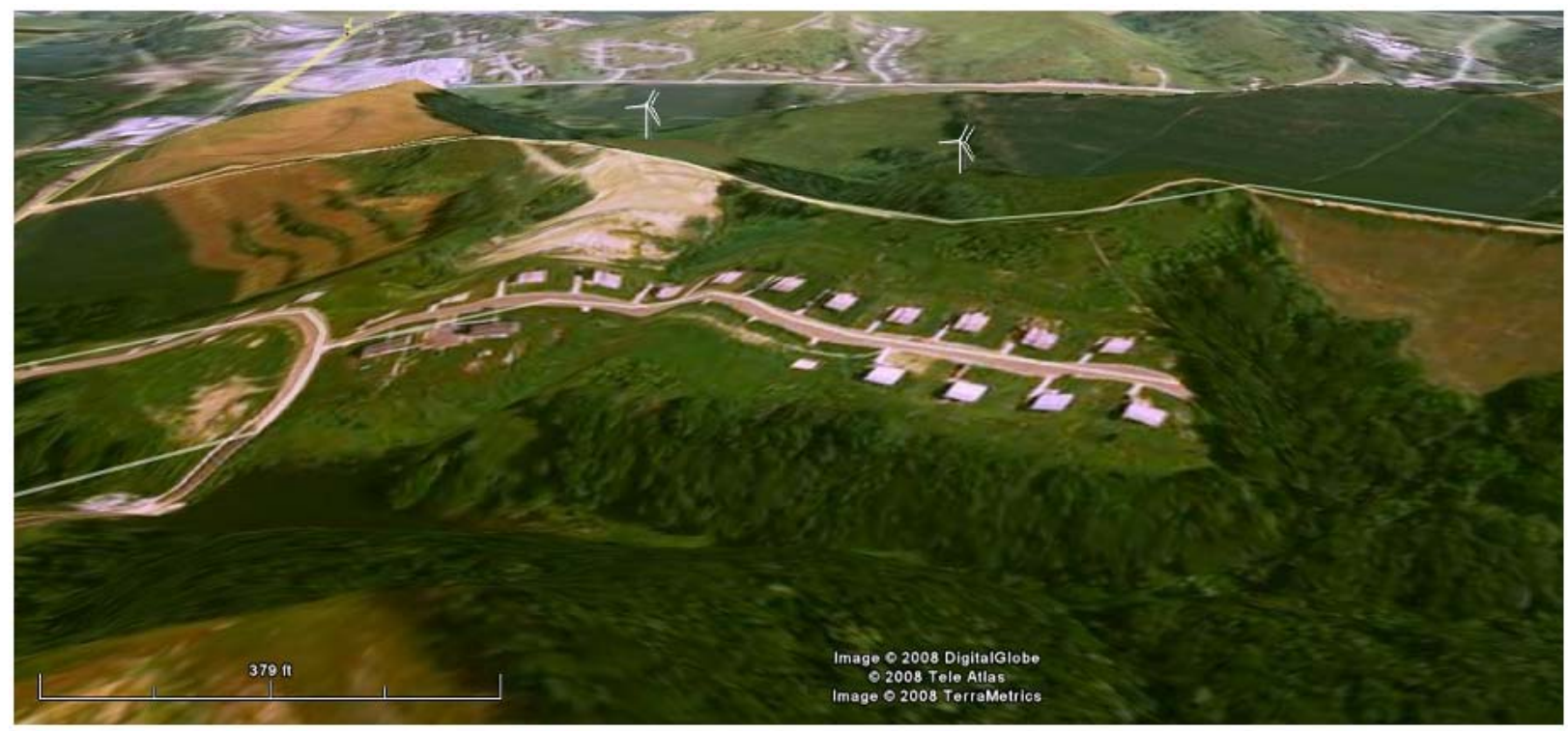

Figure 5.3-2, Kelly Subdivision, Northern View, Post-Construction 


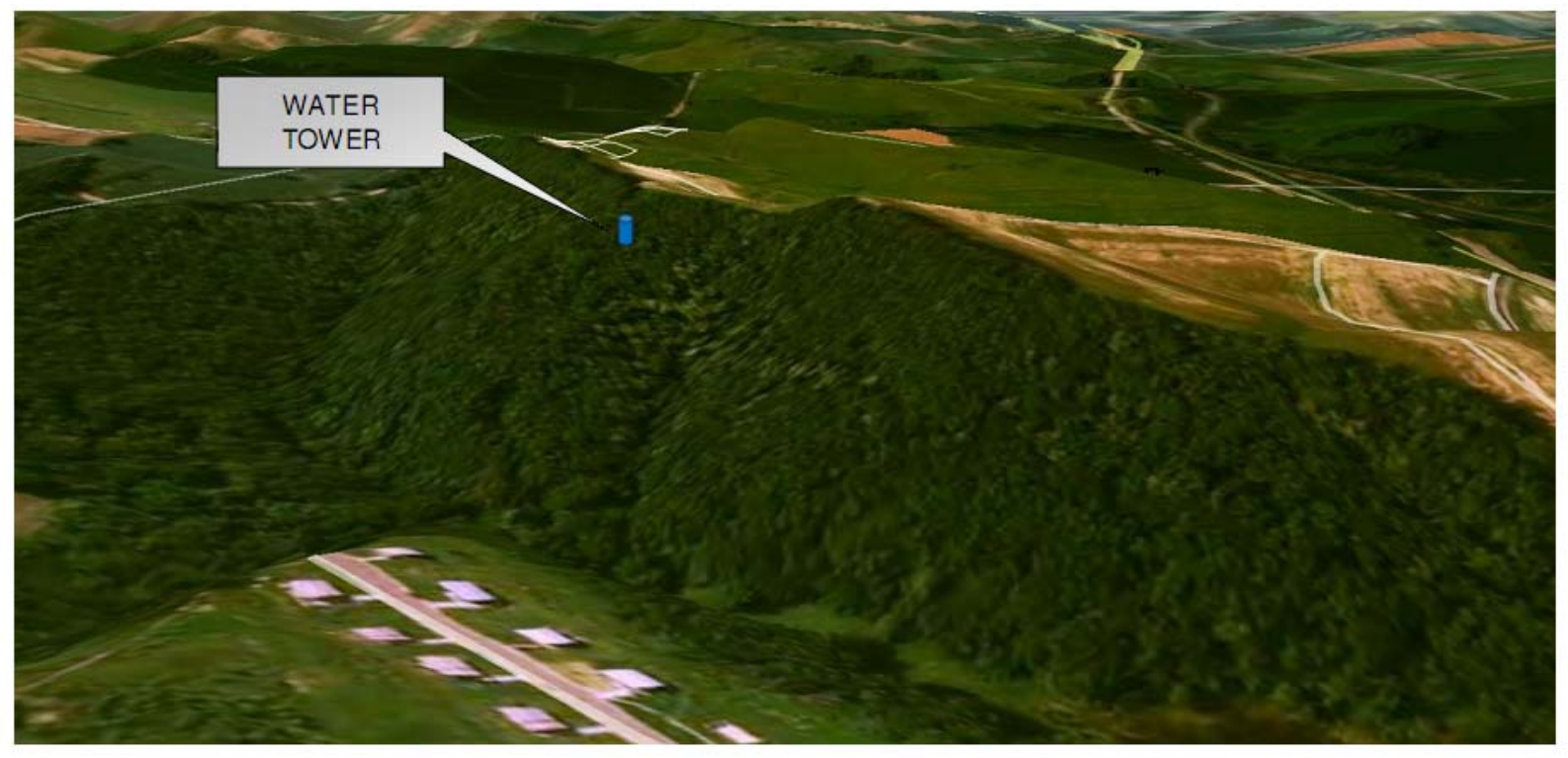

Figure 5.3-3, Kelly Subdivision, Southern View, Pre-Construction

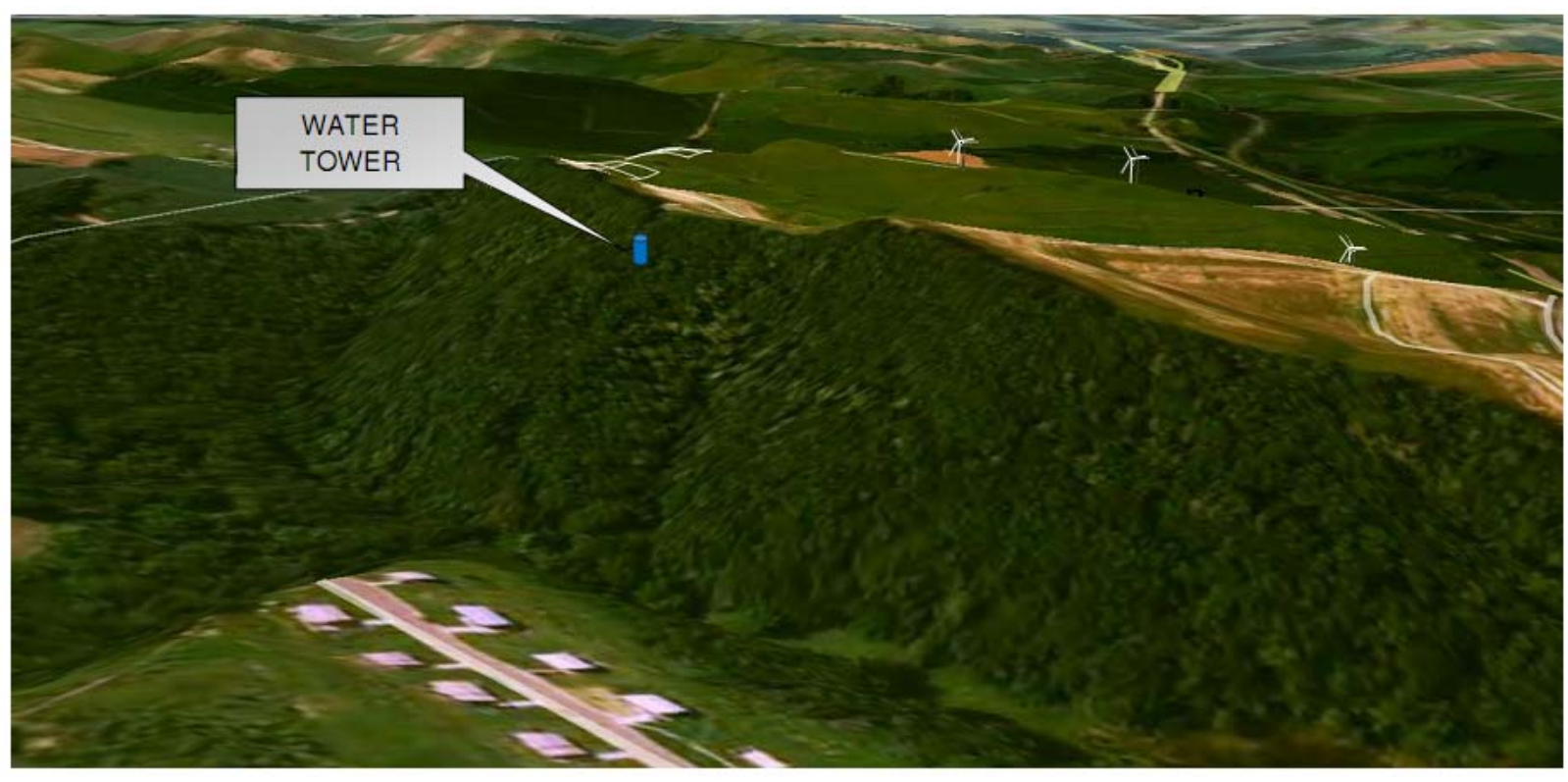

Figure 5.3-4, Kelly Subdivision, Southern View, Post-Construction 


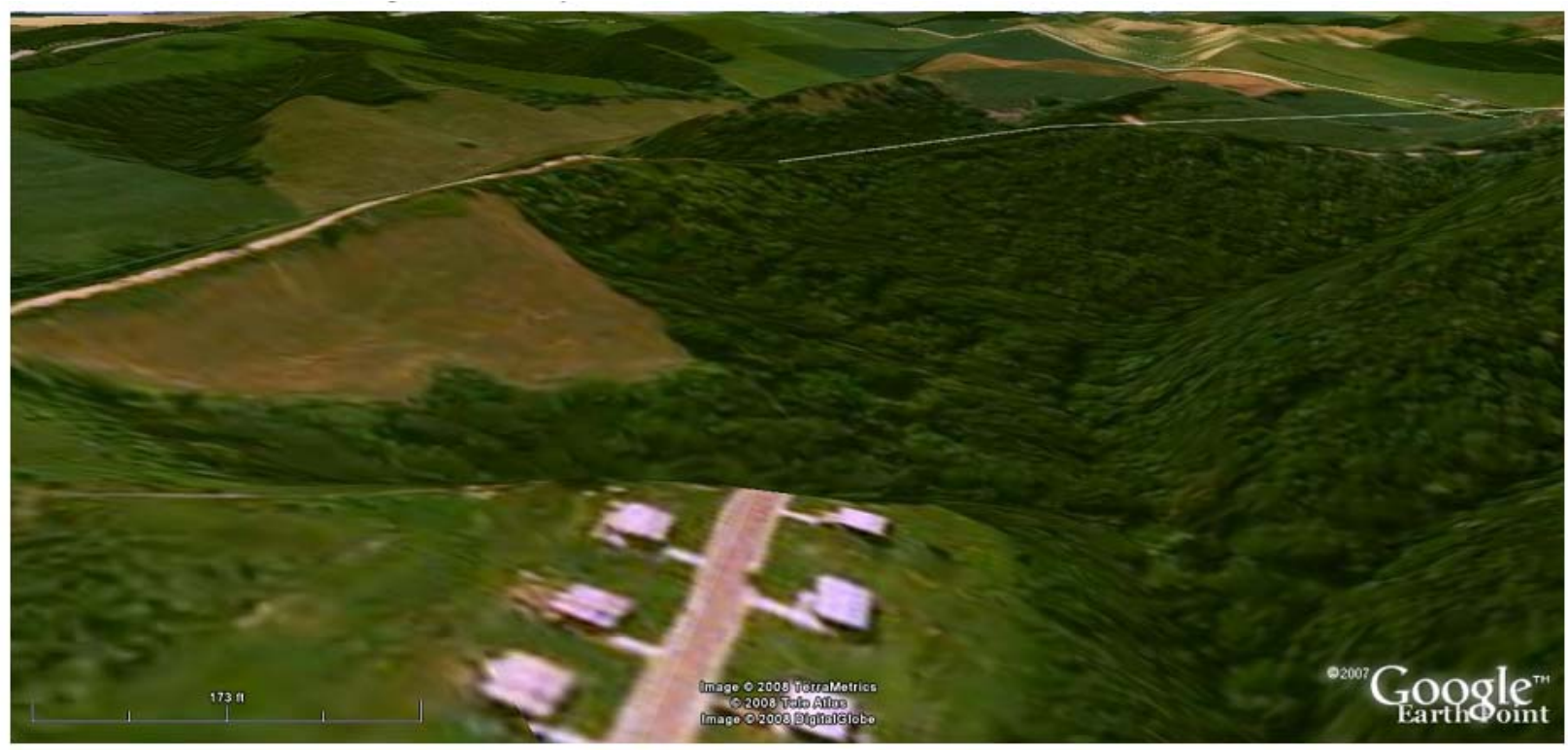

Figure 5.3-4, Kelly Subdivision, South East View, Pre-Construction

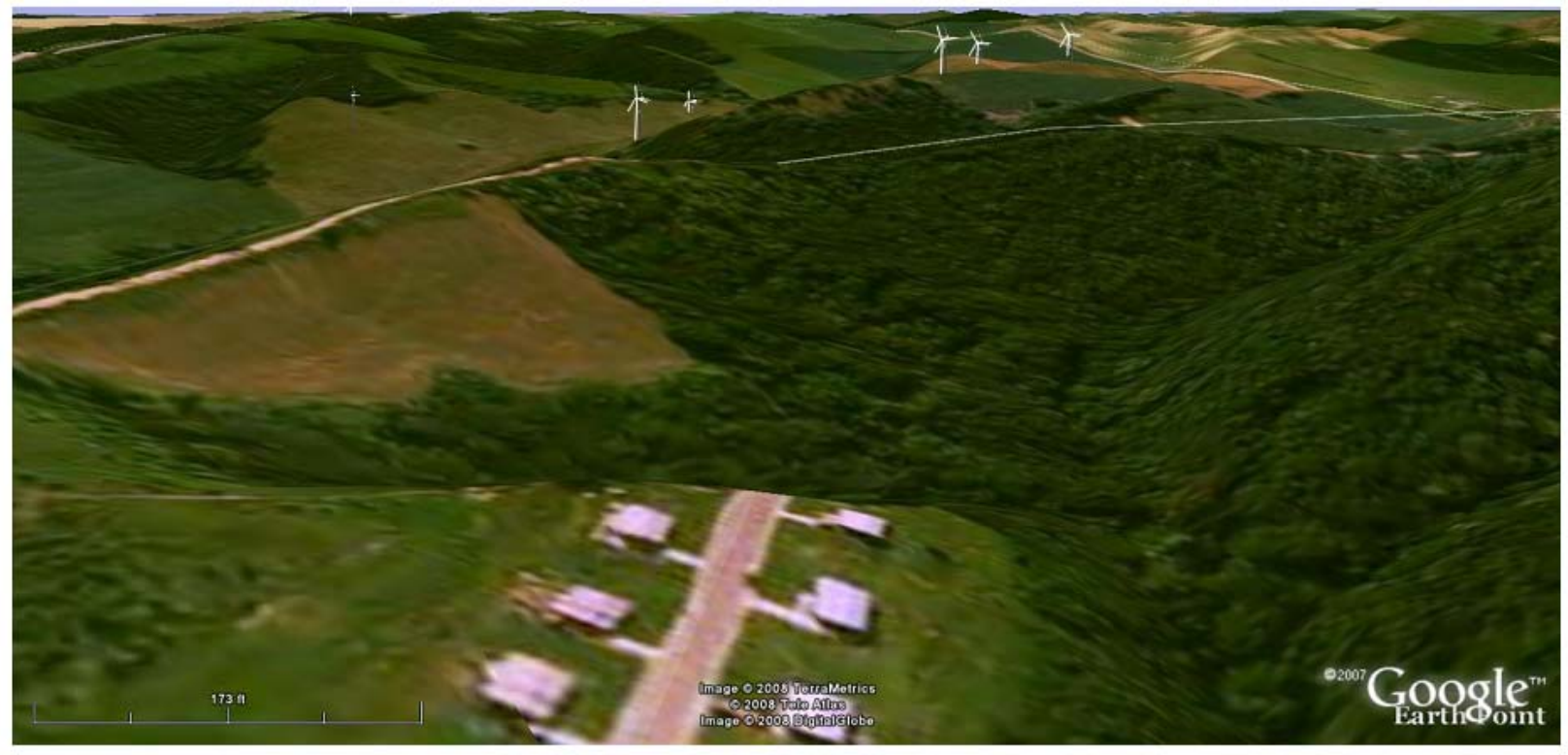

Figure 5.3-5, Kelly Subdivision, South East View, Post-Construction 


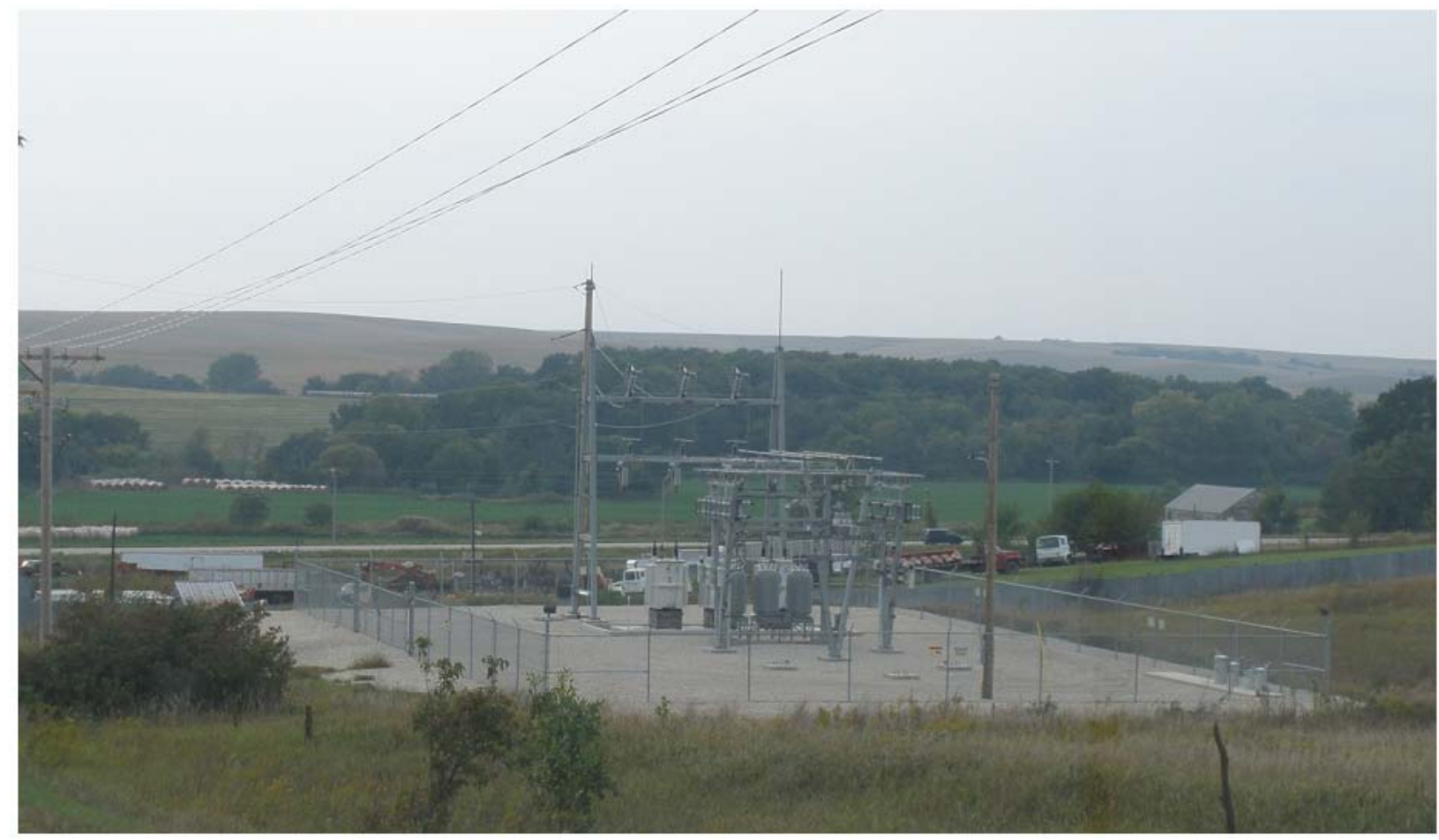

Figure 5.3-6, View from Thunderway Site

At Thunderway, there are roughly 25 non-Indian homes within a one-mile radius of the nearest wind turbine. The Western Winnebago is primarily farm land and pasture lands. Twenty wind turbines would be quite a change to the area, but it is a remote area and many Nebraskans have become accustomed to seeing wind farms nearby. The visual impact to the area should not be too significant due to the distance to scattered housing and the remoteness to Winnebago.

\subsection{Environmental- Avoided Greenhouse Gas Emissions}

An analysis was conducted to estimate greenhouse gas (GHG) emissions avoided. These calculations assumed power production based on use of the Vestas $1.65 \mathrm{MW}$ turbines, and also assumed that $100 \%$ of the energy offset was generated by coal-fired electricity. For Thunderway, the gross annual GHG emissions avoided will be approximately 62,416 tons of $\mathrm{CO}^{2}$ (see Figure 5.4-1). This would equate to 1.25 million tons over 20 years.

The gross emissions reduced for Western Winnebago would total 106,965 ton of $\mathrm{CO}^{2}$ annually and total 2.14 Million tons over 20 years. 


\begin{tabular}{|c|c|c|c|c|}
\hline \multicolumn{5}{|c|}{ GHG Emission Reduction } \\
\hline Location & $\begin{array}{c}\text { Base case } \\
\text { GHG emission } \\
\text { tCO2 }\end{array}$ & $\begin{array}{c}\text { Proposed } \\
\text { case } \\
\text { GHG } \\
\text { emission } \\
\text { tCO2 }\end{array}$ & $\begin{array}{c}\text { Gross annual } \\
\text { GHGemission } \\
\text { reduction } \\
\text { tCO2 }\end{array}$ & $\begin{array}{c}\text { Gross annual } \\
\text { GHG emission } \\
\text { reduction } \\
\text { tCO2 over } 20 \\
\text { yrs } \\
\end{array}$ \\
\hline Thunderway & 63,047 & 630 & 62,416 & $1,248,320$ \\
\hline Western & 108,045 & 1,080 & 106,965 & $2,139,300$ \\
\hline
\end{tabular}

Figure 5.4-1, Greenhouse Gas Emission Reduction

\subsection{Archaeological and Historical Resources}

The National Register of Historic Places is the official list of cultural resources worthy of preservation. Authorized under the National Historic Preservation Act of 1966, the National Register is part of a national program to coordinate and support public and private efforts to identify, evaluate, and protect historic and archeological resources. Properties listed in the Register include districts, sites, buildings, structures, and objects that are significant in American history, architecture, archeology, engineering, and culture. The National Register is administered by the National Park Service, which is part of the U.S. Department of the Interior. Figure 5.4-2 is a list of historical sites in Thurston County, none of which are near the wind sites of interest.

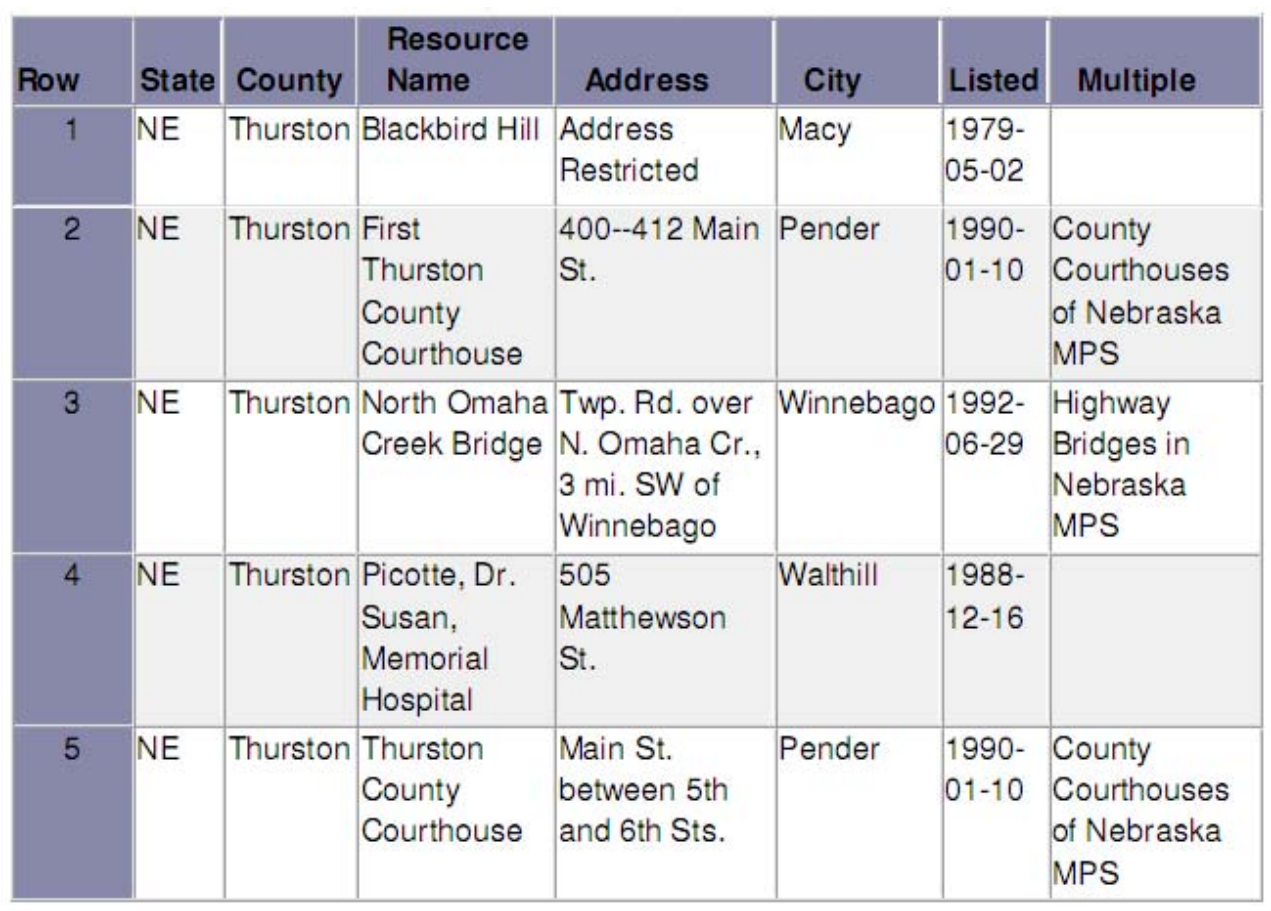

Figure 5.5-1, National Register Information System Index by County 
Mr. David Smith, the Repatriation Director of the Cultural Preservation Officer of Winnebago viewed the two met tower Sites and assessed tribal records, which consisted of the 1887 Allotment Records, State Death Records, Winnebago Tribal Maps from 1910, The Farm \& Home Plat \& Directory and Oral Tradition. The first wind project site is located 5 miles south of Emerson, Nebraska, off Highway 9. The nearest Tribal cultural properties near this site are located 3 miles east of the proposed site. The second wind project site is located 3 miles south of Winnebago, off Highway 77 . This site is southeast of the Kelly Housing Projects, in an area known as the Kelly Subdivision. The nearest cultural properties are located 1 mile north of this site. Oral Tradition states that the second site was near a battlefield from 1865. He concluded that the construction of the met towers would have no impact on Tribal Cultural Properties in the areas that belong to the Winnebago Tribe of Nebraska.

\subsection{Initial Environmental Assessment - Western Winnebago}

\begin{tabular}{|c|c|}
\hline Issue & Western Winnebago \\
\hline General Site Description & $\begin{array}{l}\text { Approximately } 631 \text { acres of trust land located within sections 22, } \\
27,28 \text {, and } 33 \text { of the township and range T26N R6E (Nebraska } \\
\text { PLSS). }\end{array}$ \\
\hline Geological/Water Use & Playa wetland areas located in section 22 \\
\hline Geological Hazard/Soil Erosion & Playa wetland areas located in section 22 \\
\hline Water Quality & No Impact \\
\hline Airborne Dust & No Impact \\
\hline Noise & $\begin{array}{l}\text { Moderate to high impact when windfarm is working at a high } \\
\text { capacity. }\end{array}$ \\
\hline Wildlife Habitat & Agricultural-use area. Minimal wildlife habitat areas. \\
\hline Fish/Wildlife Species & $\begin{array}{l}\text { The northern long-eared myotis (Myotis septentrionalis) has } \\
\text { been recorded in this area. Further study required. }\end{array}$ \\
\hline Land Use & $\begin{array}{l}\text { The land use of the immediate surrounding area to the primary } \\
\text { site is predominated by agricultural activity. }\end{array}$ \\
\hline Visual Resources & Limited impact \\
\hline Hazardous Waste & No Impact \\
\hline Traffic & No Impact \\
\hline Health/Human Safety & No Impact. \\
\hline Cultural Resources & No Impact \\
\hline Community Concerns & No Impact. \\
\hline Construction Access & $\begin{array}{l}\text { Excellent construction access is provided by Highway } 9 \text { (paved } \\
\text { road). Also, numerous unpaved roads are located throughout } \\
\text { the project area. }\end{array}$ \\
\hline Topography Observations & $\begin{array}{l}\text { Characterized by moderate sloped hills and open agricultural } \\
\text { terrain. This site has an average elevation of approximately } 1450 \\
\mathrm{ft} \text { above sea level. }\end{array}$ \\
\hline Interconnection Issues & $\begin{array}{l}\text { An NPPD substation is located } 7.3 \text { miles distance. NPPD } 345 \text { KV } \\
\text { transmission line is located } 0.73 \text { miles distance. A substation is } \\
\text { located } 3.6 \text { miles distance. }\end{array}$ \\
\hline Other & None \\
\hline
\end{tabular}




\subsection{Initial Environmental Assessment - Thunderway}

\begin{tabular}{|c|c|}
\hline Issue & Thunderway \\
\hline General Site Description & $\begin{array}{l}\text { Approximately } 485 \text { acres of trust land located within sections } 13 \\
\text { and } 24 \text { of the township and range T26N R8E and in sections } 18 \\
\text { and } 19 \text { of the township and range T26N R9E (Nebraska PLSS). }\end{array}$ \\
\hline Geological/Water Use & $\begin{array}{l}\text { Play wetlands located in section } 13 \text { of T26N R8E and section } 19 \\
\text { of range T26N R9E. }\end{array}$ \\
\hline Geological Hazard/Soil Erosion & $\begin{array}{l}\text { Play wetlands located in section } 13 \text { of T26N R8E and section } 19 \\
\text { of range T26N R9E. }\end{array}$ \\
\hline Water Quality & No Impact \\
\hline Airborne Dust & No Impact \\
\hline Noise & $\begin{array}{l}\text { Moderate to high impact when windfarm is working at a high } \\
\text { capacity. }\end{array}$ \\
\hline Wildlife Habitat & No Impact \\
\hline Fish/Wildlife Species & $\begin{array}{l}\text { The northern long-eared myotis (Myotis septentrionalis) has } \\
\text { been recorded in this area. Further study required. }\end{array}$ \\
\hline Land Use & $\begin{array}{l}\text { The area is a mixed-use area including agricultural, light } \\
\text { industrial, and residential activity. A metal recycling yard and a } \\
\text { Northeastern NPPD substation are both located within the } \\
\text { project site boundaries. }\end{array}$ \\
\hline Visual Resources & $\begin{array}{l}\text { Potentially high impact due to the close proximity of turbines to } \\
\text { residential housing. Also, future housing to be developed in } \\
\text { area. }\end{array}$ \\
\hline Hazardous Waste & No Impact \\
\hline Traffic & No Impact \\
\hline Health/Human Safety & No Impact. \\
\hline Cultural Resources & No Impact \\
\hline Community Concerns & No Impact. \\
\hline Construction Access & $\begin{array}{l}\text { Excellent construction access is provided by Highway } 77 \text { and } 75 \text {, } \\
\text { both of which are paved roads. Also, numerous unpaved roads } \\
\text { are located throughout the project area. }\end{array}$ \\
\hline Topography Observations & $\begin{array}{l}\text { The project site area is characterized by sloping features and } \\
\text { widely varying elevations. The area is topographically } \\
\text { dominated by a large wooded hill. }\end{array}$ \\
\hline Interconnection Issues & $\begin{array}{l}\text { An NPPD substation is located } 1.2 \text { miles distance. NPPD } 345 \mathrm{KV} \\
\text { transmission line is located } 2.7 \text { miles distance. A substation is } \\
\text { located within project site boundaries. }\end{array}$ \\
\hline Other & Future housing to be developed in area. \\
\hline
\end{tabular}




\subsection{Conclusions and Recommendations}

\subsection{WinnaVegas Casino Wind Turbine}

The Winnebago Tribe of Nebraska has been pursuing wind development in various forms for nearly ten years. Wind monitoring utilizing loaned met towers from NREL took place during two different periods. From April 2001 to April 2002, a 20-meter met tower monitored wind data at the WinnaVegas Casino on the far eastern edge of the Winnebago reservation in lowa. NREL concluded that the average wind speed of 11.5 miles per hour was marginal, but that the project could be feasible depending on utility rates and net metering policies.

In late 2006, a 50-meter tower was installed, and subsequently monitored wind data at the WinnaVegas site from late 2006 through late 2008. Significant challenges with the NREL wind monitoring equipment limited the availability of valid data, but based on the available data, average wind speeds between 13.6 - 14.3 miles were indicated, reflecting a 2+/3- wind class. Based on the anticipated cost of energy produced by a WinnaVegas wind turbine, and the utility policies and rates in place at this time, a WinnaVegas wind project did not appear to make economic sense. However, if substantial grant funding were available for energy equipment at the casino site, and if either Woodbury REC backup rates were lower, or NIPCO was willing to pay more for wind power, a WinnaVegas wind project could be feasible.

\subsection{Western Winnebago Wind Project}

With funding remaining in the DOE-funded project budget, Red Mountain also considered a number of other possible wind project locations on the Winnebago reservation. Initial indications and conclusions from that study led to installation of a Nebraska Public Power District (NPPD)-owned 60-meter met tower on the Western Winnebago site in January 2009. Winnebago was approached by NPPD in spring-2008 about installing met towers on Winnebago lands west of the town of Winnebago. NPPD is actively pursuing wind energy for its system, and although it cannot develop projects on its own, is committed to development of the wind resources in the area. After multiple discussions between NPPD and Winnebago, in early 2009, the met tower was installed at a site identified in the study. The NPPD met tower was installed pursuant to a verbal agreement with NPPD which provided for power from any ultimately developed project on the Western Winnebago site to be sold to NPPD. If Winnebago developed the wind project and sold power to another utility, NPPD would seek compensation from Winnebago for the tower and data analysis. Results from the first seven months of wind monitoring at the Western Winnebago site were as expected at just over 7 meters per second at 50-meter tower height, reflecting Class 4 wind speeds, adequate for commercial development.

Winnebago had a unique opportunity to install a met tower in conjunction with NPPD's program to promote large wind project development which allowed Winnebago to assess its resources without cost. Initial indications of wind speed are positive. If wind data collected in the remaining months of the twelve-month collection period is consistent with that collected in the first seven months, the Western Winnebago site may present an interesting opportunity for Winnebago. While the initial economics analyzed using projected wind data indicate a somewhat higher levelized cost of energy than may be of interest to NPPD at this time, Winnebago could work with a wind developer to expand the project to include surrounding farmland, and improve the economics of such a project. Given the distance to 
nearby substations, and high cost of interconnection at higher voltage transmission lines, Winnebago would likely need to be part of a larger project in order to reduce power costs to more attractive levels. Another alternative would be to pursue grant funding for a portion of development or equipment costs, which would also help reduce the cost of power produced. Winnebago and its ultimate development partner should consider initiating an interconnection request, as described in the Appendix.

\subsection{Thunderway Wind Project}

The NREL tower from the WinnaVegas site was taken down in late 2008, re-instrumented and installation attempted on the Thunderway site south of the Winnebago community. If Winnebago is interested in pursuing a community-scale wind project at the Thunderway Site, the NREL 50-meter met tower should be re-installed at the site as soon as possible, so that wind data can be collected. Based on projected wind speeds, current equipment costs, and the project's proximity to substations for possible interconnection, a Thunderway community-scale wind project could make economic sense. From a Winnebago community perspective, if NPPD net metering rules were extended to projects of this size, and/or Burt County allowed net metering at attractive rates, the community could realize benefits from such a project. Although a portion of the site is in the CRP program, with US Department of Agriculture approval wind turbines are allowed on CRP land, with no reduction in CRP payments.

\subsection{Lessons Learned}

Through this study, Winnebago was able to determine that its proposed facility-scale wind project did not make sense, primarily due to the utility policies in place at that location, but learned from initial analyses that proposed community-scale and commercial-scale wind projects were possible on Winnebago tribal lands.

One of the important lessons learned from this project includes the need to monitor met tower sites and data on a more regular basis. The large gaps in data at the WinnaVegas site created a challenge in assessing the project potential on a timely basis. With more complete data, the poor WinnaVegas economics would have been recognized earlier, and Winnebago could have requested that the met tower be moved to one of the other sites much earlier in the project timeframe.

In addition, better coordination of information about possible sites and availability would have allowed met towers to be installed on a more timely basis, and allowed for more detailed analysis of potential projects during the timeframe of this DOE-funded effort. 


\subsection{Appendix}

\subsection{WinnaVegas Met Tower Site Notes Summary as of October 9, 2008}

Winnebago, NE

Lat: N $42^{\circ} 13.758^{\prime}$ or $42^{\circ} 13^{\prime} 45.48^{\prime \prime}$

Long: W $96^{\circ} 18.603^{\prime}$ or $96^{\circ} 18^{\prime} 36.18^{\prime \prime}$

Site \#: 0002 (thru Dec 2007); 8002 (from 14 Jan 2008)

In May 2007, there was a one month data gap from 1/27/07 to 2/19/07 and could not be retrieved. In addition, 40m level anemometer was not plugged in. The missing data was a data gap within the data chip.

In December 2007, the datalogger was down and data was missing from Jun - Dec 2007.

Troubleshooting the logger indicated that it was hit by lightning. The logger was sent to NRG for repairs while a "test" datalogger was sent to Winnebago as a replacement.

In July 2008, data was analyzed from 1/14/08 - 4/8/08; data was taken with the replacement data logger. A review of the summary data in the Symphonie Reader software showed no problems with the speed data, however, the direction data indicated that the top direction vane at $49 \mathrm{~m} \mathrm{AGL}$ is malfunctioning. This vane showed the wind coming from the NNW $70 \%$ of the time, with most of the remaining wind coming from the N, NW and WNW. The wind rose for the lower direction vane $(37 \mathrm{~m}$ $A G L)$ appeared okay with the winds more evenly distributed around the compass. The start and stop times on the files were suspicious. A review of the wind roses confirmed that the direction vane at $49 \mathrm{~m}$ AGL is malfunctioning; the direction vane at $37 \mathrm{~m}$ AGL may have recently malfunctioned. $40 \mathrm{~m}$ wind speed data is all zeros (excluded) for mid January - May 2007 while the shear factor $(30 \mathrm{~m}-50 \mathrm{~m})$ is fairly low, 0.11 .

In September 2008, the met tower went down again. Data was downloaded and an attempt was made to swap out the data card. With both the old card and new card, the system would not allow viewing of any screens. It continued to prompt to for reprogramming data card and neither card would reprogram. A quick glimpse of some of the readings displayed " $0 \mathrm{~m} / \mathrm{s}$ " for two channels. The disconnected "spd + 3 " channel wire was reconnected. The met tower is currently down and will need to be fixed or replaced. 


\subsection{Shear Factor Calculations}

Alpha - Shear Factor

Alpha $=\ln ($ windspeed2/windspeed1)/ln(height2/height1)

\begin{tabular}{|c|c|c|c|c|c|c|c|c|c|}
\hline \multicolumn{6}{|c|}{ Wind Speeds } & \multicolumn{3}{|c|}{ Alpha, 2008} & \multirow{2}{*}{$\begin{array}{c}\text { Alpha, } \\
2007 \\
\text { alpha, } \\
50 \mathrm{~m} / 30 \mathrm{~m}\end{array}$} \\
\hline & $\begin{array}{c}10 \mathrm{~m} \\
\text { historic }\end{array}$ & $\begin{array}{l}30 \mathrm{~m} \\
2008\end{array}$ & $\begin{array}{l}40 \mathrm{~m} \\
2008\end{array}$ & $\begin{array}{l}50 \mathrm{~m} \\
2007\end{array}$ & $\begin{array}{l}50 \mathrm{~m} \\
2008\end{array}$ & $\begin{array}{c}\text { alpha, } \\
30 \mathrm{~m} / 40 \mathrm{~m}\end{array}$ & $\begin{array}{c}\text { alpha, } \\
50 \mathrm{~m} / 10 \mathrm{~m}\end{array}$ & $\begin{array}{c}\text { alpha, } \\
50 \mathrm{~m} / 30 \mathrm{~m}\end{array}$ & \\
\hline Jan & 4.67 & 6.4 & 6.2 & 6.7 & 6.8 & 0.1104 & 0.2305 & 0.1187 & 0.1205 \\
\hline Feb & 4.71 & 6 & 5.7 & 6.5 & 6.3 & 0.1783 & 0.1748 & 0.0955 & 0.1243 \\
\hline Mar & 5.13 & 5.6 & 5.4 & 6.7 & 6 & 0.1264 & 0.2194 & 0.1351 & 0.1205 \\
\hline Apr & 5.34 & 5.7 & 5.4 & 6.8 & 6 & 0.1879 & 0.1920 & 0.1004 & 0.0584 \\
\hline May & 4.99 & & & 7.2 & & & & & 0.0551 \\
\hline Dec & 4.67 & & & 5.3 & & & & & \\
\hline Avg & & & & & & 0.1508 & 0.2089 & 0.1124 & 0.0958 \\
\hline
\end{tabular}


8.3 WinnaVegas Casino Energy Audit

\section{WinnaVegas Casino}

Energy Audit

SPONSORED BY:

Woodbury County Rural Electric Cooperative

PREPARED BY:

The Energy Group

2704 Easton Blvd.

Des Moines, IA 50317

$515 / 564-1045$ 


\section{TABLE OF CONTENTS}

1. Executive Summary

2. Building Description

$4-5$

3. Energy Efficiency Improvements

$6-12$

Install Energy Efficient Fluorescent Lighting

Install Energy Efficiency Compact Fluorescent Lighting

Install LED Exit Lights

Install Electric Supplemental Heat

Install Variable Speed Kitchen Hood Controls

Install Low Flow Sprayers

4. Supporting Documents 


\section{SECTION 1. EXECUTIVE SUMMARY}

The Energy Group has undertaken this energy analysis as requested by the Woodbury County Rural Electric Cooperative on behalf of their customer, WinnaVegas Casino. The goal of this effort is to improve the energy efficiency of the existing building.

The facility has already implemented many energy efficiency improvements. These include major improvements to the heating, ventilating, and cooling system. The large air-handling units for the casino have been converted from $100 \%$ outdoor air to a return air system. Heat recovery wheels and demand controlled ventilation are used in all major heating and cooling units. Much of the fluorescent lighting has been upgraded to high efficiency F32T8 systems. A comprehensive direct digital control / energy management system by American Auto-Matrix has been installed and is used extensively by staff. Finally, facilities staff does an excellent job of maintaining and overseeing the operation of the heating and cooling equipment to minimize energy use.

Several energy efficiency opportunities were found in the area of lighting improvements, kitchen hood controls, low flow sprayers, and the use of electric supplemental heat.

For this building envelope improvements were not considered for three reasons. First, the casino has already added insulation where possible in the casino area. Second, additional insulation should be considered when a new roof is contemplated over the bingo hall. Additional insulation could at that time be installed between the roof deck and the roof membrane. Third, due to the large amount of people, slot machines, and lights in the casino area a significant amount of heat is generated internally. Much of the energy used for heating is actually for conditioning outside air for ventilation and not for envelope heat losses.

Items considered, but not fully analyzed include: replacement of the lighting system in the high portion of bingo area ceiling (this area has dimmable compact fluorescent fixtures. A quick calculation revealed that replacement with three lamp troffers with similar overall lumens would only save a minor amount of energy) and replacement of the smaller rooftop mounted heating, ventilating, and air-conditioning equipment. There have been some significant improvements in the cooling efficiency of packaged rooftop mounted equipment. When the existing equipment is in need of replacement consideration should be given to installing this higher efficiency equipment. Generally, the simple payback for the incremental cost difference is 5 to 7 year.

The energy calculations were made using spreadsheet calculations rather than a computer simulation. The avoided cost per kWh varies depending on the impact of demand. Generally, the last block of energy (kWh) was used and added to the estimated demand savings.

The average cost per gallon of propane used in the analysis was $\$ 1.55$, as reported by the Facilities Engineer. 


\section{SECTION 2. BUILDING DESCRIPTION}

\section{Envelope/Insulation:}

\section{Casino Building}

The pitched roof area of the casino has R-19 insulation installed along the roof trusses. This has been added since the original construction. The flat roof portion of the building is insulated and facilities staff believes the insulation level is approximately R-10. The insulation is located between the roof deck and the roof membrane, and without removal of a sample it could not be verified. There are very few windows in the facility. The building's wall insulation is undetermined.

\section{Facility Occupancy}

The casino operates 24 hours per day, 7 days per week. Some areas like the restaurants and offices have lower occupancy hours.

\section{Heating, Ventilating, and Air Conditioning}

Heating and cooling is provided by several different systems. Two large built-up air-handling units are located outside the main casino area and provide the heating, cooling and ventilation for the casino. These units were originally $100 \%$ outdoor air units but have had return air added to the units to reduce energy costs. There are three (3) AAON air-handling units that serve the ballroom/bingo area.

Additionally, there are a variety of smaller single zone packaged rooftop units that serve specific areas throughout the complex.

All of the large air handling units described previously use sophisticated energy management control strategies to reduce energy consumption. The strategies include total heat recovery, demand based ventilation, and variable speed fan speed control.

Cooling for the Casino area is provided by two McQuay, model number ALP135C air-cooled chillers. The cooling is distributed by cooling coils in the two air-handling units. The AAON units have integral direct expansion cooling.

The kitchen has an Econ-Aire makeup air unit that is operated 24 hours per day, 7 days per week.

\section{Domestic Water Heating}

Domestic hot water is provided by a Raypack hot water boiler with an input rating of 320,000 Btuh. The hot water is stored in two State storage tanks of approximately 100 gallons capacity each. 


\section{Lighting}

The predominant source of lighting is a combination of incandescent lamps which are, in many cases, dimmed and linear fluorescent four foot fixtures. The fluorescent four-foot fixtures are used in the office and support areas. The incandescent fixtures are located in the casino and adjacent areas.

The ballroom/bingo hall uses dimmable compact fluorescent lamps in the ceiling and along the perimeter.

\section{Energy Management}

The entire facility is controlled by an American Auto-Matrix energy management system. The facility engineer works closely with the system installer to reduce energy use as much as possible. The recent improvements to the air-handling equipment by adding return air and demand based ventilation control has significantly reduced the energy consumption for treating ventilation air throughout the facility.

\section{SECTION 3: ENERGY EFFICIENCY IMPROVEMENTS}

We have evaluated several Energy Efficiency Improvements (EEI's) appropriate to this facility. Each of the following subsections includes a description of a specific EEI and related existing conditions.

\section{Lighting Improvements}

- Fluorescent T12 to T8 lighting

- Incandescent to compact fluorescent lighting

- Exit lights to LED

Electric supplemental heat

Variable speed kitchen hood controls

Low flow kitchen sprayers

Simple payback analysis is used to evaluate each item. Any simple payback analysis involves an amount of uncertainty. Electricity and propane prices may change. Hours of operation may vary from year to year. Weather conditions can also greatly impact the actual savings for any potential project. Finally, assumptions made by the analyst are part of any analysis and actual conditions may vary. The Energy Group does not warrant or guarantee any estimated savings or costs shown in this analysis. 


\section{EEI Development Sheet}

EEI Title: Install Energy Efficient Fluorescent Lighting

\section{Description of existing conditions:}

Much of the existing fluorescent lighting has already been changed to energy efficient T8 lighting. However, there were still some fixtures that could be retrofitted to this energy savings technology.

\section{Description of energy efficiency improvement measures:}

Replace the remaining standard efficiency T12 fluorescent lighting with high efficiency T8 lighting.

\section{Energy savings calculation:}

The appendix contains the summary of these estimated savings.

\section{Electric Savings: $\quad 19,870 \mathrm{kWh}$ or $\$ 780$}

\section{EMI Cost Estimate:}

Cost obtained from past experience. Actual costs may vary.

Total Cost $=\$ 5,897$

5. Simple Payback $=\$ 5,897 / \$ 780=7.6$ years

\section{EEI Development Sheet}

EEI Title: Install Energy Efficient Compact Fluorescent Lighting

\section{Description of existing conditions:}

The current lighting system includes a large number of incandescent lamps used in hanging lamp and ceiling recessed fixtures. Many of these incandescent lamps are controlled by a dimmer system, but it was understood during the data gathering that the system is dialed to a lower than full capacity and is rarely changed. For the purposes of the energy savings calculations, we have assumed that the 
dimmer has adjusted the current levels to about $50 \%$ of full capacity. At $50 \%$ capacity the energy reduction is approximately $40 \%$. For example, a 65 -watt incandescent flood lamp controlled to the $50 \%$ levels uses approximately 36 watts.

\section{Description of energy efficiency improvement measures:}

In lieu of permanently lowering the incandescent lamps to $50 \%$ or so, a compact fluorescent lamp could be installed to save a significant amount of energy. The system could then be returned to full power as to not damage the compact fluorescent lamps. Care will have to be taken to find the correct lamp in an acceptable color rendition.

\section{Energy savings calculation:}

The appendix contains the summary of these estimated savings.

\section{Electric Savings: $109,958 \mathrm{kWh}$ or $\$ 4,217$}

\section{EMI Cost Estimate:}

Cost based on $\$ 15 /$ lamp installed cost. This rather high cost allows for installation and the used of a more expensive lamp or even dimmable compact fluorescents if needed.

Total Cost $=\$ 4,950$

5. Simple Payback $=\$ 4,950 / \$ 4,217=1.2$ years

\section{EEI Development Sheet \\ EEI Title: LED Exit Sign Lights}

\section{Description of existing conditions:}

The lamps used in the existing exit signs are 15-watt incandescent lamps. These lamps have a relatively short life span and also consume a fair amount of energy, since they operate 8,760 hours per year.

\section{Description of energy efficiency improvement measures:}

The existing fixtures can be easily retrofitted with an LED retrofit kit. The LED lamps only use 2.4 watts per fixture and the lamps are rated to last nearly 15 years. 


\section{Energy savings calculation:}

The appendix contains the summary of these estimated savings.

\section{Electric Savings: $2,418 \mathrm{kWh}$ or $\$ 93$}

\section{EMI Cost Estimate:}

Cost obtained from previous experience.

$$
\text { Total Cost }=\$ 150
$$

5. Simple Payback $=\$ 150 / \$ 93=1.6$ years

\section{EEI Development Sheet}

EEI Title: Install Electric Supplemental Heat in the Main Air-handling Units

\section{Description of existing conditions:}

The two existing air-handling units for the casino area have gas-fired (propane) heating.

\section{Description of energy efficiency improvement measures:}

A review of a single days demand profile indicates there may be a cost-effective opportunity to install a supplemental electric heating system to be used between the hours of 12:00 a.m. and 6:00 a.m. The intention is to size the amount of resistance electric heat so as to not increase the overall daily demand. In this way only the energy usage (kWh) and its cost increases, and not overall demand. Duct heaters could be installed in the discharge duct of the air-handling units to pick up a portion of the heating load between the appropriate hours. This item would require coordination with the controls contractor to make the system utilize the electric resistance coils for heating when the demand conditions were appropriate. The coils would be staged on to track the normal daily decline in other electric usage.

\section{Energy savings calculation:}

The appendix contains the summary of these calculations.

Increased Electric Usage: $87,360 \mathrm{kWh}$ or $\$ 3,189$

Propane Savings: $\mathbf{6 , 2 4 2}$ gallons or $\$ 9,675$ 
Overall Savings: $\$ 6,486$

\section{EMI Cost Estimate:}

The costs are based on average cost as shown in RS Means Mechanical Estimating Guide.

Total Estimated Cost: $\$ 18,000$

5. Simple Payback $=\$ 18,000 / \$ 6,486=2.8$ years

\section{EEI Development Sheet}

EEI Title: Install Variable Speed Controls on Kitchen Hood System

\section{Description of existing conditions:}

The main kitchen hood operates 24 hours per day, 7 days per week. The kitchen operates from approximately 6:00 a.m. until 10:00 p.m. The hood is single speed, exhausting a constant volume of air regardless of the amount of particulate in the area.

\section{Description of energy efficiency improvement measures:}

A variable speed control system could be installed to reduce the amount of conditioned air exhausted by the system when the areas is closed and when the amount of cooking is less than full capacity. Additionally, the variable speed drive on the motor will reduce motor electric consumption at less that full operation.

\section{Energy savings calculation:}

The appendix contains the summary of these calculations.

\section{Electric Savings: $10,656 \mathrm{kWh}$ or $\$ 389$ \\ Propane Savings: 755 gallons or $\$ 1,171$ \\ Overall Savings: $\$ 1,560$}

\section{EMI Cost Estimate:}

The costs are based on average cost as previously provided by Melink Corporation. 
5. Simple Payback $=\$ 8,940 / \$ 1,560=5.7$ years

\section{EEI Development Sheet}

EEI Title: Install Low Flow Sprayers on Kitchen Dish Rinsing Sprayers

\section{Description of existing conditions:}

The existing dish rinsing sprayers appear to be standard flow sprayers. These sprayers are used to remove larger food particles from the dishes prior to washing.

\section{Description of energy efficiency improvement measures:}

A new generation of low flow dish rinsing sprayers is becoming widely used by kitchens in restaurants to save energy in both the form of reduced hot water needs and in water savings itself. The low flow sprayers provide a force full concentrated flow that usually provides the same or more user satisfaction as compared to older full flow models.

\section{Energy savings calculation:}

The appendix contains the summary of these calculations.

\section{Propane Savings: $\mathbf{5 1 1}$ gallons or $\$ 793$}

\section{EMI Cost Estimate:}

The costs are based on average retail cost of low flow sprayers.

Total Estimated Cost: $\$ 300$

5. Simple Payback $=\$ 300 / \$ 793=.4$ years 


\subsection{WinnaVegas Supporting Documents}

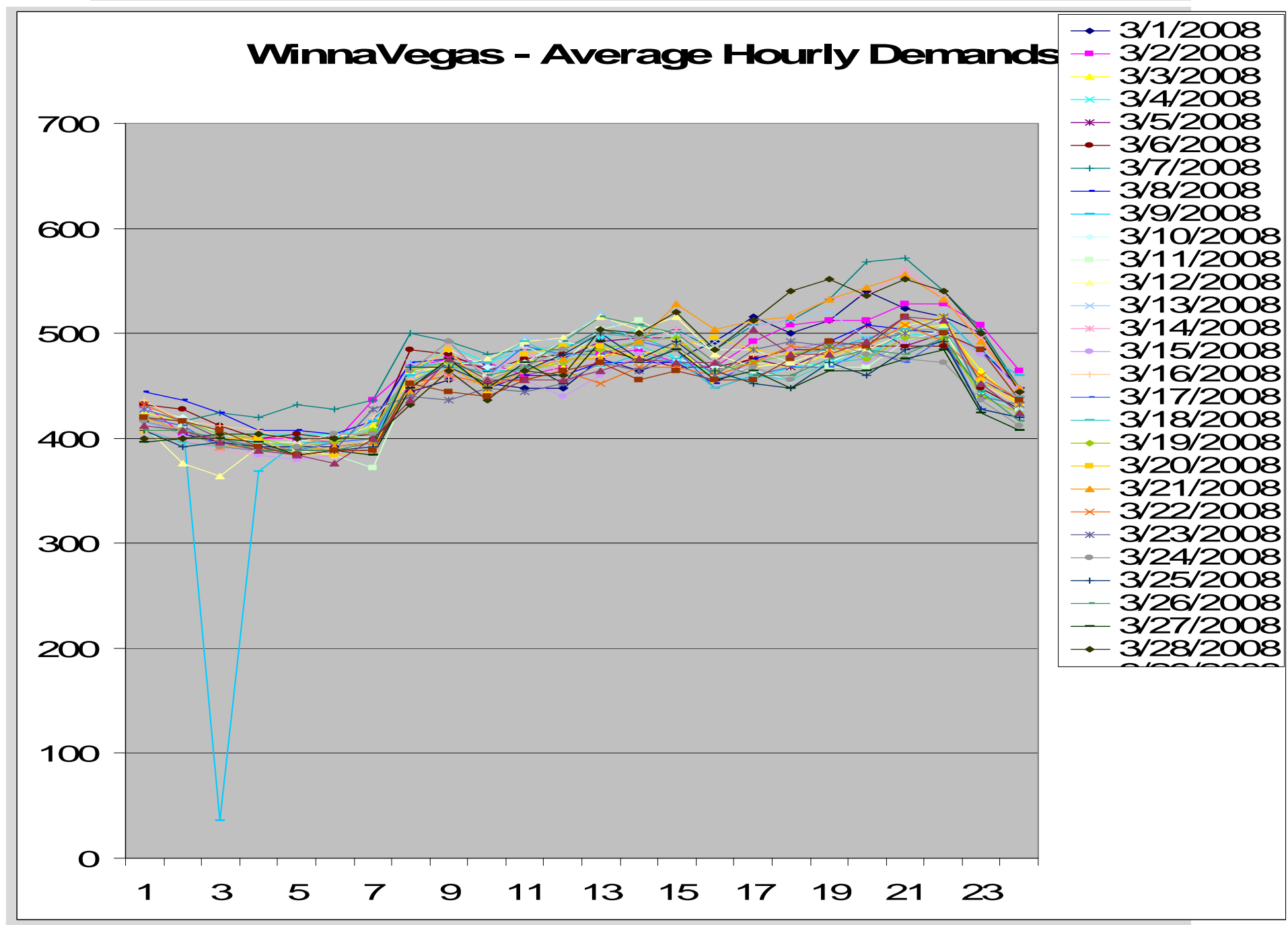




\begin{tabular}{|c|c|c|c|c|c|c|c|c|c|c|c|c|}
\hline & & & & $\begin{array}{c}\text { WinnaVegas } \\
\text { Casino }\end{array}$ & & & & & \multicolumn{4}{|c|}{ Based on New Rates Effective Jan. 2008} \\
\hline & & & & & Cost & Cost & WAPA & Total & \multirow{2}{*}{$\begin{array}{c}\text { Block } 1 \\
5 \\
\text { Cents/kWh }\end{array}$} & \multirow{2}{*}{\multicolumn{2}{|c|}{$\begin{array}{c}\text { Block } 2 \\
3.65 \\
\text { Cents/kWh } \\
\end{array}$}} & \multirow{2}{*}{ 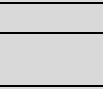 } \\
\hline Month & & kWh & Demand & & kWh & Demand & Credit & Cost & & & & \\
\hline Jan & & 342,800 & 571 & & $\$ 14,054$ & $\$ 8,853$ & $\$ 4,065$ & $\$ 18,842$ & 114,200 & $\$ 5,710$ & 228,600 & $\$ 8,344$ \\
\hline Feb & & 320,400 & 569 & & $\$ 13,232$ & $\$ 8,828$ & $\$ 3,351$ & $\$ 18,709$ & 113,800 & $\$ 5,690$ & 206,600 & $\$ 7,541$ \\
\hline Mar & & 341,200 & 506 & & $\$ 13,820$ & $\$ 7,843$ & $\$ 3,370$ & $\$ 18,293$ & 101,200 & $\$ 5,060$ & 240,000 & $\$ 8,760$ \\
\hline Aprl & & 333,600 & 680 & & $\$ 14,013$ & $\$ 10,546$ & $\$ 2,982$ & $\$ 21,577$ & 136,000 & $\$ 6,800$ & 197,600 & $\$ 7,212$ \\
\hline May & & 414,400 & 805 & & $\$ 16,183$ & $\$ 11,272$ & $\$ 3,558$ & $\$ 23,897$ & 161,000 & $\$ 8,050$ & 253,400 & $\$ 9,249$ \\
\hline Jun & & 450,400 & 954 & & $\$ 17,796$ & $\$ 13,367$ & $\$ 3,238$ & $\$ 27,925$ & 190,800 & $\$ 9,540$ & 259,600 & $\$ 9,475$ \\
\hline Jul & & 514,000 & 987 & & $\$ 20,043$ & $\$ 13,826$ & $\$ 3,508$ & $\$ 30,361$ & 197,400 & $\$ 9,870$ & 316,600 & $\$ 11,556$ \\
\hline Aug & & 509,200 & 954 & & $\$ 19,793$ & $\$ 13,356$ & $\$ 3,779$ & $\$ 29,370$ & 190,800 & $\$ 9,540$ & 318,400 & $\$ 11,622$ \\
\hline Sept & & 416,800 & 865 & & $\$ 16,421$ & $\$ 12,118$ & $\$ 3,862$ & $\$ 24,677$ & 173,000 & $\$ 8,650$ & 243,800 & $\$ 8,899$ \\
\hline Oct & & 375,200 & 868 & & $\$ 15,014$ & $\$ 12,157$ & $\$ 3,459$ & $\$ 23,712$ & 173,600 & $\$ 8,680$ & 201,600 & $\$ 7,358$ \\
\hline Nov & & 342,000 & 669 & & $\$ 13,367$ & $\$ 9,368$ & $\$ 3,320$ & $\$ 19,415$ & 133,800 & $\$ 6,690$ & 208,200 & $\$ 7,599$ \\
\hline Dec & & 345,200 & 578 & & $\$ 13,240$ & $\$ 8,097$ & $\$ 3,580$ & $\$ 17,757$ & 115,600 & $\$ 5,780$ & 229,600 & $\$ 8,380$ \\
\hline Total & & $4,705,200$ & & & $\$ 186,976$ & $\$ 129,631$ & $\$ 42,072$ & $\$ 274,535$ & & $\$ 90,060$ & & $\$ 105,996$ \\
\hline & & & & & & & & & & & & \\
\hline & & & & & & & & & & & & \\
\hline \multicolumn{13}{|c|}{ Approximate } \\
\hline Baseload & & 342,914 & 634 & & & & & & & & & \\
\hline & & & & & & & & & & & & \\
\hline \multicolumn{13}{|c|}{ Approximate } \\
\hline \multicolumn{2}{|c|}{ Cooling Usage } & 590,229 & 279 & & & & & & & & & \\
\hline & & & & & & & & & & & & \\
\hline \multirow{2}{*}{\multicolumn{2}{|c|}{ Cooling Cost }} & $\$ 21,543$ & $\$ 21,589$ & & Total & $\$ 43,133$ & & & & & & \\
\hline & & & & & & & & & & & & \\
\hline
\end{tabular}

\begin{tabular}{|c|c|c|c|c|c|c|c|c|c|c|c|c|}
\hline \multirow[b]{2}{*}{ Lighting Upgrade } & \multirow[b]{2}{*}{ Area } & \multirow{2}{*}{$\begin{array}{c}\text { Fixture } \\
\text { Qty }\end{array}$} & \multicolumn{3}{|c|}{ Fixture Wattage } & \multirow{2}{*}{$\begin{array}{c}\text { Annual } \\
\text { Operating } \\
\text { Hours }\end{array}$} & \multicolumn{4}{|c|}{ Energy Consumption (kWh) } & \multirow{2}{*}{$\begin{array}{c}\text { Estimated } \\
\text { Project } \\
\text { Costs }\end{array}$} & \multirow{2}{*}{$\begin{array}{c}\text { Simple } \\
\text { Payback } \\
\text { (Years) }\end{array}$} \\
\hline & & & $\begin{array}{c}\text { Curre } \\
\text { nt }\end{array}$ & Proposed & Savings & & Current & Proposed & Savings & $\begin{array}{l}\text { Annual } \\
\text { Savings }\end{array}$ & & \\
\hline Incan. to CFL & Rest. Ceiling & 57 & 36 & 15 & 21 & 6570 & 13482 & 5617 & 7864 & $\$ 305.60$ & $\$ 855.00$ & 2.8 \\
\hline Incan. to CFL & Rest. Hanging & 50 & 36 & 15 & 21 & 6570 & 11826 & 4928 & 6899 & $\$ 268.07$ & $\$ 750.00$ & 2.8 \\
\hline Incan. to CFL & Main Casino Floor & 150 & 66 & 15 & 51 & 8760 & 86724 & 19710 & 67014 & $\$ 2,564.59$ & $\$ 2,250.00$ & 0.9 \\
\hline Incan. to CFL & Behind Bar & 6 & 36 & 15 & 21 & 8760 & 1892 & 788 & 1104 & $\$ 42.24$ & $\$ 90.00$ & 2.1 \\
\hline Incan. to CFL & Poker Room & 15 & 66 & 15 & 51 & 8760 & 8672 & 1971 & 6701 & $\$ 256.46$ & $\$ 225.00$ & 0.9 \\
\hline Incan. to CFL & Souvenir Store & 8 & 36 & 15 & 21 & 6570 & 1892 & 788 & 1104 & $\$ 42.89$ & $\$ 120.00$ & 2.8 \\
\hline Incan. to CFL & Main Entry & 10 & 65 & 15 & 50 & 8760 & 5694 & 1314 & 4380 & $\$ 167.62$ & $\$ 150.00$ & 0.9 \\
\hline Incan. to CFL & Vestibule & 8 & 65 & 15 & 50 & 8760 & 4555 & 1051 & 3504 & $\$ 134.10$ & $\$ 120.00$ & 0.9 \\
\hline Incan. to CFL & Office by entry & 2 & 65 & 15 & 50 & 8760 & 1139 & 263 & 876 & $\$ 33.52$ & $\$ 30.00$ & 0.9 \\
\hline Incan. to CFL & Cashiers & 20 & 65 & 15 & 50 & 8760 & 11388 & 2628 & 8760 & $\$ 335.24$ & $\$ 300.00$ & 0.9 \\
\hline \multirow[t]{3}{*}{ Incan. to CFL } & Exit by Restaurant & 4 & 65 & 15 & 50 & 8760 & 2278 & 526 & 1752 & $\$ 67.05$ & $\$ 60.00$ & 0.9 \\
\hline & Totals & & & & & & & & 109958 & $\$ 4,217.37$ & $\$ 4,950.00$ & 1.2 \\
\hline & & & & & & & & & & & & \\
\hline
\end{tabular}




\begin{tabular}{|c|c|c|c|c|c|c|c|c|c|c|c|c|}
\hline \multirow{2}{*}{ Lighting Upgrade } & \multirow{2}{*}{ Area } & \multirow{2}{*}{$\begin{array}{c}\text { Fixture } \\
\text { Qty }\end{array}$} & \multicolumn{3}{|c|}{ Fixture Wattage } & \multirow{2}{*}{$\begin{array}{l}\text { Annual } \\
\text { Operating } \\
\text { Hours }\end{array}$} & \multicolumn{4}{|c|}{ Energy Consumption (kWh) } & \multirow{2}{*}{$\begin{array}{c}\text { Estimated } \\
\text { Project } \\
\text { Costs }\end{array}$} & \multirow{2}{*}{$\begin{array}{c}\text { Simple } \\
\text { Payback } \\
\text { (Years) }\end{array}$} \\
\hline & & & $\begin{array}{c}\text { Curre } \\
\text { nt }\end{array}$ & Proposed & Savings & & Current & Proposed & Savings & $\begin{array}{l}\text { Annual } \\
\text { Savings }\end{array}$ & & \\
\hline & & & & & & & & & & & & \\
\hline Incan. to CFL & Rest. Ceiling & 57 & 36 & 15 & 21 & 6570 & 13482 & 5617 & 7864 & $\$ 305.60$ & $\$ 855.00$ & 2.8 \\
\hline Incan. to CFL & Rest. Hanging & 50 & 36 & 15 & 21 & 6570 & 11826 & 4928 & 6899 & $\$ 268.07$ & $\$ 750.00$ & 2.8 \\
\hline Incan. to CFL & Main Casino Floor & 150 & 66 & 15 & 51 & 8760 & 86724 & 19710 & 67014 & $\$ 2,564.59$ & $\$ 2,250.00$ & 0.9 \\
\hline Incan. to CFL & Behind Bar & 6 & 36 & 15 & 21 & 8760 & 1892 & 788 & 1104 & $\$ 42.24$ & $\$ 90.00$ & 2.1 \\
\hline Incan. to CFL & Poker Room & 15 & 66 & 15 & 51 & 8760 & 8672 & 1971 & 6701 & $\$ 256.46$ & $\$ 225.00$ & 0.9 \\
\hline Incan. to CFL & Souvenir Store & 8 & 36 & 15 & 21 & 6570 & 1892 & 788 & 1104 & $\$ 42.89$ & $\$ 120.00$ & 2.8 \\
\hline Incan. to CFL & Main Entry & 10 & 65 & 15 & 50 & 8760 & 5694 & 1314 & 4380 & $\$ 167.62$ & $\$ 150.00$ & 0.9 \\
\hline Incan. to CFL & Office by entry & 2 & 65 & 15 & 50 & 8760 & 1139 & 263 & 876 & $\$ 33.52$ & $\$ 30.00$ & 0.9 \\
\hline Incan. to CFL & Cashiers & 20 & 65 & 15 & 50 & 8760 & 11388 & 2628 & 8760 & $\$ 335.24$ & $\$ 300.00$ & 0.9 \\
\hline Incan. to CFL & Exit by Restaurant & 4 & 65 & 15 & 50 & 8760 & 2278 & 526 & 1752 & $\$ 67.05$ & $\$ 60.00$ & 0.9 \\
\hline & & & & & & & & & & & & \\
\hline & Totals & & & & & & & & 109958 & $\$ 4,217.37$ & $\$ 4,950.00$ & 1.2 \\
\hline & & & & & & & & & & & & \\
\hline
\end{tabular}




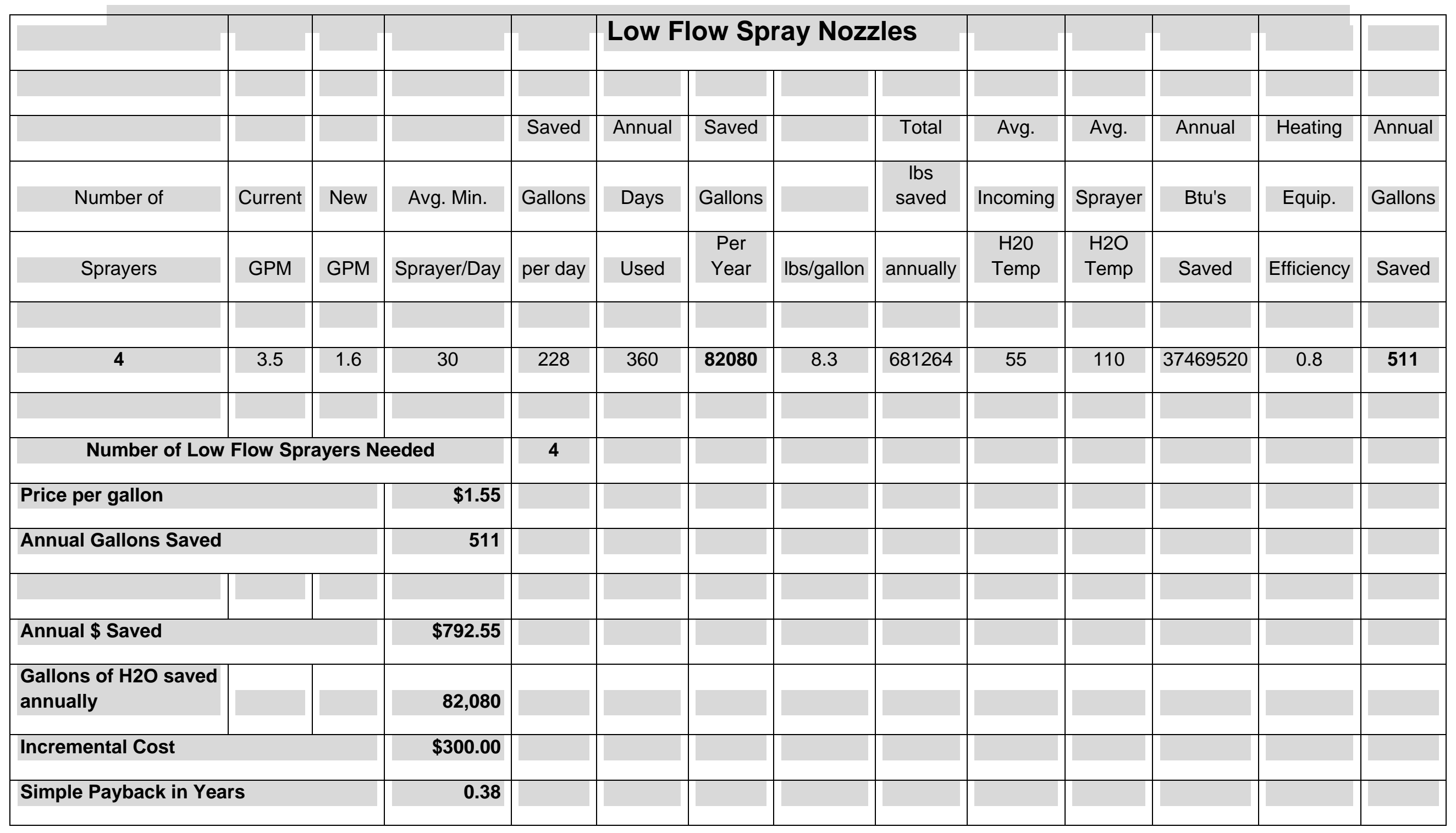




\begin{tabular}{|c|c|c|c|c|c|c|}
\hline \multicolumn{5}{|c|}{ Potential Exhaust Hood Control Savings } & & \\
\hline \multicolumn{7}{|c|}{ Motor Savings } \\
\hline \multicolumn{3}{|c|}{ A. Operating hours per day } & & 24 & & \\
\hline \multicolumn{3}{|c|}{ B. Operating days per week } & & 7 & & \\
\hline \multicolumn{3}{|c|}{ C. Operating weeks per year } & & 52 & & \\
\hline \multicolumn{3}{|c|}{ D. Horsepower of fan motors } & & 2 & & \\
\hline \multicolumn{2}{|c|}{ E. Cost per kWh } & & & 0.0365 & & \\
\hline \multicolumn{3}{|c|}{ F. Total Time $=A \times B \times C$} & & 8736 & & \\
\hline \multicolumn{4}{|c|}{ G. Total kWh/HP/Yr $=0.746 / .90 \times \mathrm{F}$} & 7241.2 & & \\
\hline H. & J. & $\begin{array}{c}K=F x \\
J\end{array}$ & L. & M. & $\begin{array}{c}N=L I \\
M\end{array}$ & $\begin{array}{c}O=K x \\
N\end{array}$ \\
\hline $\begin{array}{c}\% \\
\text { Rated }\end{array}$ & $\%$ Run & Time & Output & System & Input & kWh I \\
\hline RMP & Time & (Hrs/Yr) & (kW/HP) & Efficiency & (kW/HP) & HP / Yr \\
\hline 100 & $9 \%$ & 786.24 & 0.746 & 0.9 & 0.829 & 651.7 \\
\hline 90 & $11 \%$ & 960.96 & 0.544 & 0.9 & 0.604 & 580.8 \\
\hline 80 & $14 \%$ & 1223.04 & 0.382 & 0.9 & 0.424 & 519.1 \\
\hline 70 & $35 \%$ & 3057.6 & 0.256 & 0.9 & 0.284 & 869.7 \\
\hline 60 & $18 \%$ & 1572.48 & 0.161 & 0.9 & 0.179 & 281.3 \\
\hline 50 & $13 \%$ & 1135.68 & 0.093 & 0.9 & 0.103 & 117.4 \\
\hline 40 & $0 \%$ & 0 & 0.048 & 0.9 & 0.053 & 0.0 \\
\hline 30 & $0 \%$ & 0 & 0.020 & 0.9 & 0.022 & 0.0 \\
\hline 20 & $0 \%$ & 0 & 0.015 & 0.9 & 0.017 & 0.0 \\
\hline 10 & $0 \%$ & 0 & 0.010 & 0.9 & 0.011 & 0.0 \\
\hline
\end{tabular}




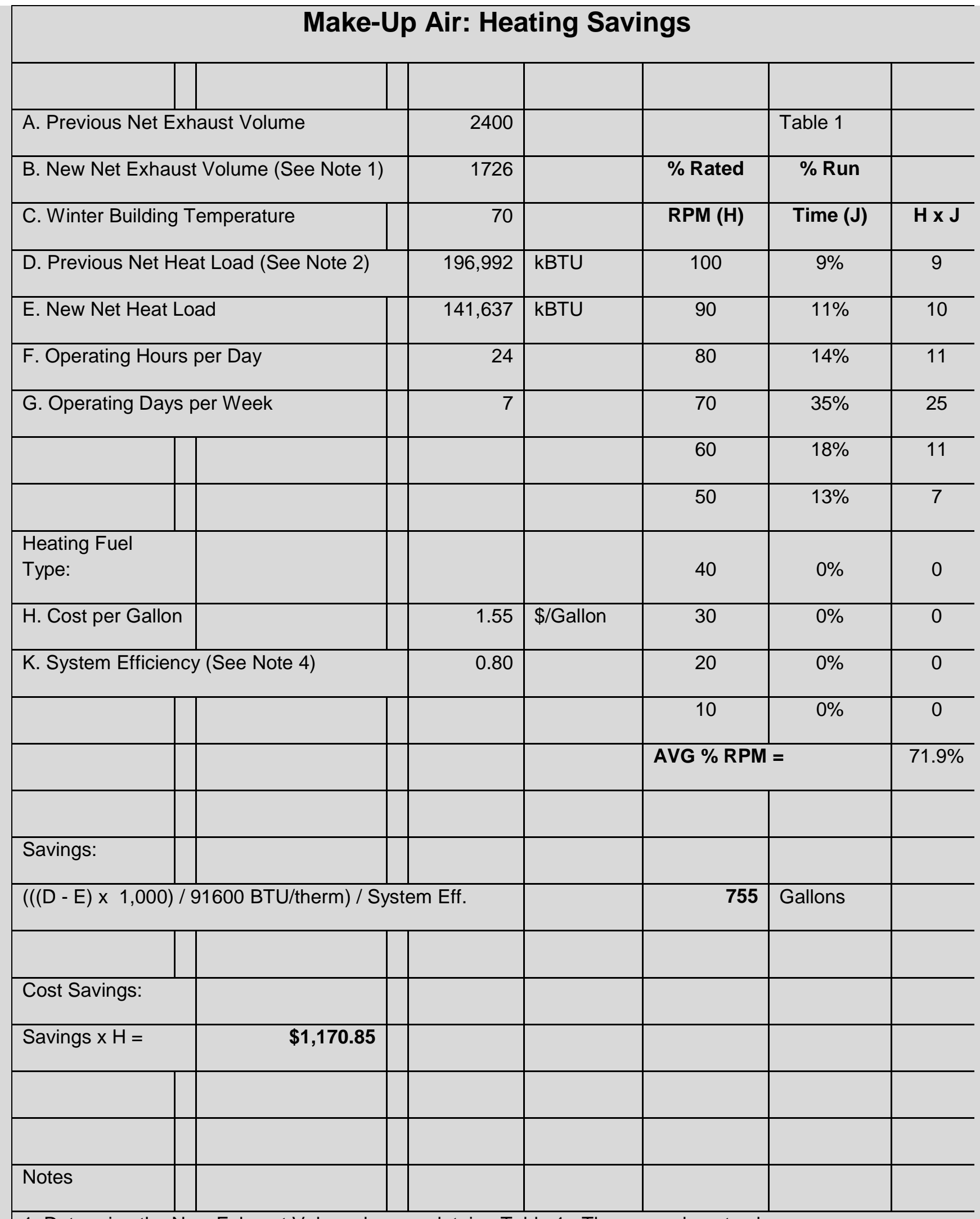

1. Determine the New Exhaust Volume by completeing Table 1. The new exhaust volume 


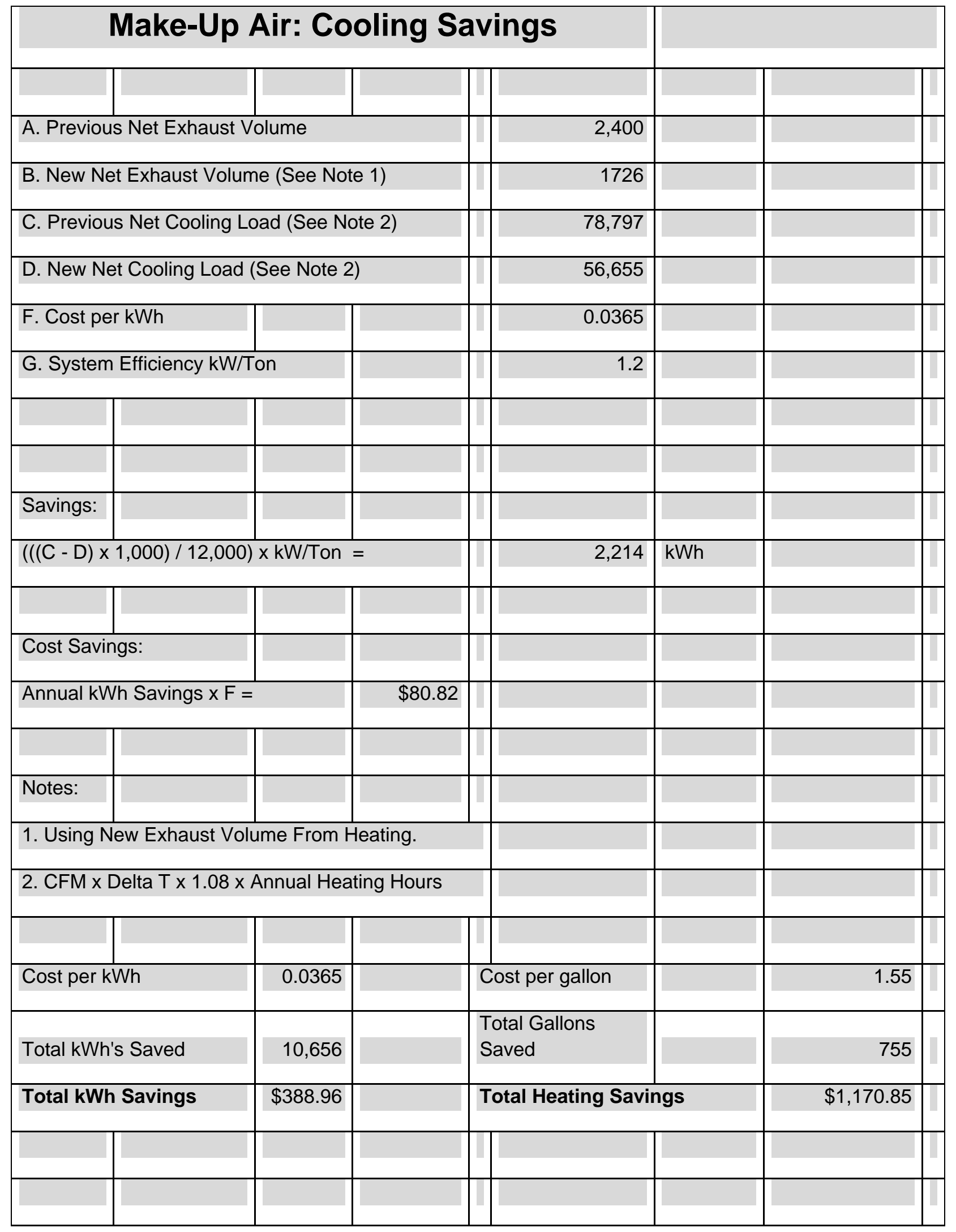




\begin{tabular}{|l|l|l|l|l|l|l|l|l|}
\hline & & & & \multicolumn{2}{|l|}{ Total Savings } & $\$ 1,559.81$ & \\
\hline & & & & & & & \\
\hline \multicolumn{2}{|l|}{ Cost of Installation } & & & & & & & \\
\hline & Materials: & $\$ 7,500$ & Per hood & & & & \\
\hline & Labor & 24 & $\begin{array}{l}\text { Hrs./per } \\
\text { hood }\end{array}$ & & & & & \\
\hline & Labor Cost & $\$ 60$ & Per Hr. & & & & & \\
\hline & \# of Hoods & 1 & & & & & & \\
\hline & & & & Total Cost of Installation & $\$ 8,940$ & & \\
\hline & & & & & & & & \\
\hline
\end{tabular}




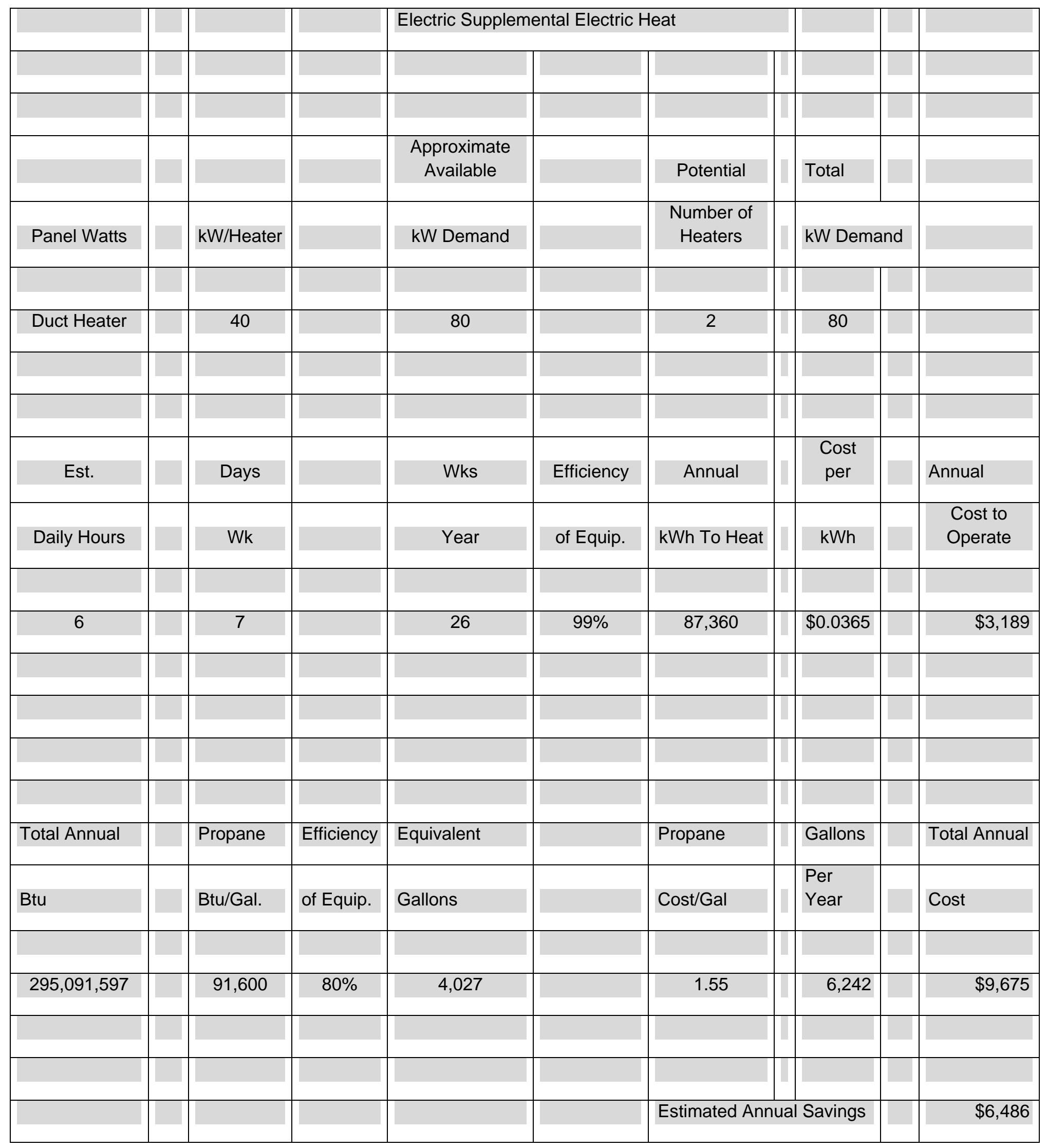




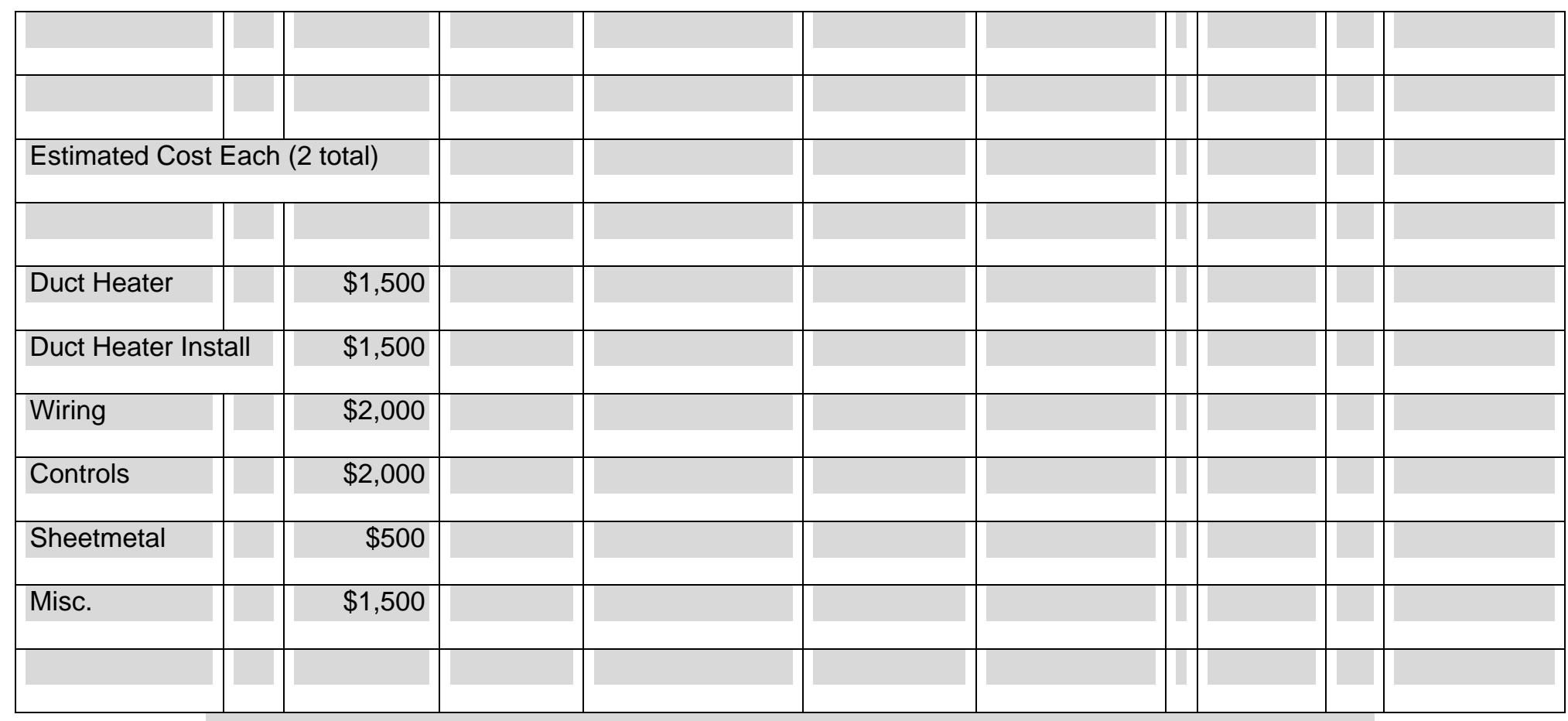

END OF REPORT 


\subsection{Blackhawk Community Center Energy Audit}

\section{Energy Audit}

\section{Presented By: Nebraska Public Power District}

\section{Executive Summary}

Nebraska Public Power District, reviewed Blackhawk Community Center in Winnebago, Nebraska for potential energy and cost saving improvements. This report also recommends low-cost energy conservation and maintenance improvements that will reduce the operating cost of the facility. The improvements recommended include:

Listed below are energy savings items: Shortest-term payback and long-term payback recommendations.

\section{Short Term Payback: Less than 2 years}

- Replace worn or damaged seals, sweeps, and thresholds to reduce air infiltration around the doors.

- Changing the filters monthly or on a regular basis.

- Clean the condensing unit coils every spring before the cooling season begins to ensure the optimum heat transfer.

- Seal all duct work with liquid mastic or foil tape.

- Perform routine inspection and cleaning of the refrigeration equipment coils.

- Use compact fluorescent lamps as replacement bulbs to the incandescent bulbs.

- Use the VendingMiser ${ }^{\mathrm{TM}}$ to reduce the energy use for the pop machines.

- Install motion detectors where applicable to shut off lights and exhaust fans.

- Change out T-12 fluorescents to T-8 fluorescents

- Change out 400 watt metal halides to 227 watt T-8 HPM Light Fixture or similar product.

\section{Long Term Payback: Greater than 2 years}

- Install variable frequency drive on motors. (circulating pumps)

- Have qualified technician verify that controls system is working properly.

\section{Introduction}

Certified Energy Manager from Nebraska Public Power District performed an audit of Blackhawk Community Center on May 14th, 2008. This service was provided at no cost because Blackhawk Community Center is a customer of Nebraska Public Power District.

This report has been kept intentionally brief and non-technical. If you desire more detailed information on any of the recommendations presented or have questions about 
other potential projects, we will be glad to assist you.

This information is believed to be complete and correct. However, since Nebraska Public Power District has no control in design and implementation details nor the use of the building and its components, Nebraska Public Power District cannot be responsible for any results or lack of results from building changes undertaken following this report unless clearly expressed in other documentation.

\section{Current Energy and Utility Use}

The facility uses natural gas for the majority of space heating, cooking, and water heating needs. All other energy needs are electrical. The following table illustrates the cost of energy and utility use for the facility over the past year.

\begin{tabular}{|c|c|c|c|c|c|c|c|}
\hline \multirow[t]{2}{*}{ Month } & \multicolumn{2}{|c|}{ Electricity } & \multicolumn{2}{|c|}{ Natural Gas } & & & \\
\hline & kWh & Cost & Therms & Cost & 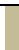 & Electric, Btus & $2,344,731,000$ \\
\hline Jan-08 & 48,200 & $\$ 1,683$ & 3420 & $\$ 4,007$ & T & Gas, Btus & $2,024,800,000$ \\
\hline Feb-08 & 42,200 & $\$ 1,434$ & 3561 & $\$ 4,370$ & 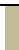 & Total, Btus & $4,369,531,000$ \\
\hline Mar-08 & 37,000 & $\$ 1,869$ & 3544 & $\$ 4,577$ & 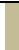 & & \\
\hline Apr-08 & 44,400 & $\$ 1,991$ & 1969 & $\$ 2,135$ & 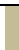 & Square Footage & 28,460 \\
\hline May-07 & 53,000 & $\$ 2,188$ & 1704 & $\$ 1,900$ & 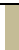 & & \\
\hline Jun-07 & 74,200 & $\$ 3,664$ & 538 & $\$ 328$ & $T$ & Btus/sq ft & $153,532.36$ \\
\hline Jul-07 & 76,800 & $\$ 4,411$ & 273 & $\$ 320$ & 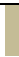 & & \\
\hline Aug-07 & 86,000 & $\$ 5,145$ & 208 & $\$ 238$ & 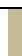 & & Energy Cost \\
\hline Sep-07 & 69,400 & $\$ 3,867$ & 232 & $\$ 260$ & $T$ & Index $\$ / \mathrm{sq} \mathrm{ft} / \mathrm{yr}$ & 1.96000 \\
\hline Oct-07 & 64,200 & $\$ 2,467$ & 697 & $\$ 762$. & T & Avg Winter kWh & 0.0410 \\
\hline Nov-07 & 51,600 & $\$ 1,720$ & 1615 & $\$ 1,877$ & 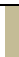 & Avg Summer kWh & 0.0536 \\
\hline Dec-07 & 40,000 & $\$ 1,456$ & 2487 & $\$ 3,018$ & 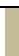 & Avg Total kWh & 0.0464 \\
\hline Total & 687,000 & $\$ 31,900$ & 20,248 & $\$ 23,797$ & & Avg Gas/Therm & 1.1753 \\
\hline
\end{tabular}




\begin{abstract}
Benchmarking
The following is a breakdown of energy use and cost for this facility. The above worksheet shows two important factors about your facility one being the Energy Use BTU/Sq./Ft/YR, and the Energy Cost Index which is an energy cost per Sq/Ft/Yr. These figures are used as benchmark figures. Probably the most important is the Energy Use Btu's per square foot. Since a Btu is a Btu if one keeps track in regard to Btu's per square foot energy use can be monitored in a fairly accurate way.

\section{Energy Use Btul Square Foot /Yearl 153,532.36}

This is based on the energy consumed kwh's and therms in relationship to the over all square footage of the facility which is approximately 28,460 square foot. United States Department of Energy classifies office buildings in the range of 110,000 Btu's per square foot/year, public safety buildings 125,000 Btu's per square foot per year. Considering this facility has a gymnasium, kitchen, law enforcement center, post office, office space, and work out center the facility may be marginally high, but not extremely out of line. This may show that the controls system that is installed that regulates the Heating Ventilating and Air Conditioning System is being managed very well by the staff. Other data shows the average cost per kwh for summer and winter and over all average and the average cost for a natural gas therm.

The Energy Cost Index is $\$ 1.96$ per square foot on annual basis. This is equal to the national average for office space. Average Energy Cost nationally is less than $\$ \mathbf{2 . 0 0}$ per square foot.

\title{
Administration and Operations
}

Overall, the building is in good structural condition and is very well maintained. The facility has a large occupancy rate and some parts are open 24 hrs a day 7 days per week.

\section{Building Envelope}

Overall the facility is in very good condition. The windows, doors, interior and exterior of the facility are very well maintained. Weather stripping and caulking should be checked regularly.

\section{Windows}

Windows are single pane glass, which is sub standard for energy efficiency. If the windows are in good condition it is hard to recommend double pane or better since pay backs can be over 10 years, however if windows are in poor condition and not performing as they should then replacement is always recommended. Another recommendation here is to make sure caulking is in good condition around the exterior of the windows.

\section{Doors}


The majority of the exterior doors are of glass construction with some insulated metal construction doors also. Weather-stripping around doors and windows needs to be checked on a regular basis.

\section{Heating and Air Conditioning Systems}

The system is (2) standard boilers rated at 1,610,000 Btu's input and 1,340,000 Btu's output. This computes to an efficiency rate of $83 \%$. This is acceptable for a building of this size. Maintenance staff said the tubes are cleaned every 3 years and the water is tested for contaminates that may foul up the system. Temperatures are closely monitored by staff and controlled by the controls system.

The following is a list of Boiler Tips to help your maintenance staff stay on top of boiler efficiency levels.

\section{Boiler Efficiency Tips}

1. Conduct flue gas analysis on the boiler every two months. Optimal percentages $\mathrm{O} 2, \mathrm{CO} 2$, and excess air in the exhaust gases are $2.2 \%, 10.5 \%$, and $10 \%$ respectively for natural gas-fired boilers. The air fuel ratio should be adjusted to recommend optimum values if possible; however, a boiler with a wide operating range may require a control system to constantly adjust the air-fuel ratio.

2. A high gas temperature often reflects the existence of deposits and fouling the fire and/or water side (s) of the boiler. The resulting loss in boiler efficiency can be closely estimated in the basis that a $1 \%$ efficiency loss occurs with every $40 \%$ increase in stack temperature.

3. The stack gas temperature be recorded immediately after boiler servicing (including tube cleaning) and this value should be used as the optimum reading. Stack gas temperature readings should be taken on a regular basis and compared with the established optimum reading at the same firing rate. A major variation in the stack gas temperature indicates a drop in efficiency and the need for either airfuel rate adjustment or boiler tube cleaning. In the absence of any reference temperature, the stack temperature at a high firing rate in a saturated steam boiler (this doesn't apply to boilers with economizers and air preheaters).

4. Check the burner head and orifice once a week and clean if necessary.

5. Check all controls frequently and keep them clean and dry.

6. The frequency and amount of blow down depend upon the amount and condition of the feed water. Check the operation of the blow down system and make sure the excessive blow down does not occur. Normally, blow down should be no more than $1 \%$ to $3 \%$ of steam output.

\section{Air Conditioning}

The facility has over 130 tons of cooling. It is water cooled system 6 air handlers with 12 fans on the roof top that shed the heat. Maintenance staff said these fans are staged in operation meaning when the system calls for a fan the appropriate number come on. We recommend that condensing unit coils be cleaned annually and filters be cleaned 
on a regular basis. During the audit it was discovered that large amounts of air was escaping from the supply system near the air handlers. These areas should be repaired and joints should be sealed with liquid mastic or foil tape.

\section{General HVAC Comments}

Reviewed schedules of occupied/unoccupied times in the controls system and found them to be acceptable.

\section{Domestic Hot Water}

Hot water temperatures should be set at 120 degrees supply water lines should be insulated.

\section{Appliances}

There is refrigeration equipment located within the school building. These include pop machines, water coolers, refrigerators, and freezers. We strongly recommend cleaning condenser coils on all refrigeration equipment annually. Dirty coils reduce the ability of the unit to dissipate heat and causes operating periods to last longer for compressor.

The following spreadsheet shows the annual savings on an energy savings device that will reduce the energy consumption for pop machines.

The VendingMiser ${ }^{\mathrm{TM}}$ is designed to operate as an intelligent power controller for cold product vending machines. With the use of the VendingMiser'm, there is a potential of a one to two year payback.

\begin{tabular}{|l|c|c|}
\hline Electric Use Of One Machine w and w/o Vending Miser & W/O Miser & With Vending Miser \\
\hline Electricity Use Per Year & $3468 \mathrm{kWh}$ & $1716 \mathrm{kWh}$ \\
\hline $\mathrm{CO}_{2}$ emissions per year @ $1.3 \mathrm{lbs} / \mathrm{kwh}$ & 2.26 Tons & 1.12 Tons \\
\hline Cost of Vending Miser & & $\$ 165.00$ \\
\hline Cost over 52 weeks (cost of electricity @ \$0.0488/ kwh) & $\$ 169.24$ & $\$ 83.74$ \\
\hline Savings & & $\$ 85.50$ per machine \\
\hline Payback (Not including Installation) & & 1.92 years simple \\
\hline
\end{tabular}


Internet site for Vending Miser

products:http://www.energysavingsolutions.com/Vending\%20Miser.htm

\section{Lighting}

Various lighting fixtures are installed throughout the school utilizing T-8 and T-12 fluorescent, metal halides and incandescent lamps.

Continue to convert building T12 fluorescent light fixtures with magnetic ballasts to F32T8s with electronic ballasts. Calculations show that for each fixture $\mathbf{4}$ tube 4 foot that is converted annual savings of $\$ 5.17$ or more can be achieved per fixture there are 2 tubes 4 foot fluorescents that if converted \$4.07 or more can be saved annually per fixture. All this depends largely upon hours of operation which were figured to be approximately 2860 hours per year. After June 30, 2010, magnetic replacement ballasts for these T12 fixtures will no longer be available for purchase. Fortunately, conversion to T8 lamps using electronic ballasts is as simple as replacing bulbs and wiring in new electronic ballast replacing the magnetic ballasts.

Install Compact Fluorescent Lamps (CFLs) to replace incandescent lights located throughout the facility. Considering CFLs use about one-quarter the energy that incandescent lamps do to produce comparable amounts of light, a conversion is recommended. In addition to being more energy efficient, these lamps can be expected to last five to ten times longer than incandescent bulbs.

The gymnasium has 24 Metal Halides that use 465 watts per fixture. By converting these metal halides to T-8 HPM Light Fixture system wattage per fixture 227 watts annual estimated savings per fixture is $\$ 32.27$. Other benefits are the T-8's put out less heat and when shut off can be turned back on immediately no delay time that metal halides have.

Consider replacing toggle switches in restrooms, classrooms, and offices with motion sensors. According to the U.S. Environmental Protection Agency, lighting energy savings from using such devices can range from $40 \%$ to $46 \%$ in classrooms, $13 \%$ to $50 \%$ in private offices, $30 \%$ to $90 \%$ in restrooms, $22 \%$ to $65 \%$ in conference rooms, $30 \%$ to $80 \%$ in corridors, and $45 \%$ to $80 \%$ in storage areas. Besides providing a means of minimizing energy consumption, additional uses of occupancy sensors include security (by indicating that an area is occupied). 


\begin{abstract}
Motors
There are some electric motors within your facility. Replacement of existing motors with more efficient models is usually cost effective for applications where the motors are heavily used. Recommend that all motors over 1 horsepower should be inventoried. Prepared data sheets can be used to record motor size, use, age, model number, estimated hours of operation, other electrical characteristics, and possibly the full load of the motor. Rule of thumb, all motors over $1 \mathrm{hp}$ and with run times over 2,000 hours per year or greater, are likely candidates for replacement by high-efficiency motors (at least when they fail and must be replaced). Motors are important part of any facilities operation; so don't allow yourself to get into a position to install any old motor that's available.

Also motor housings should be cleaned on a periodic basis to help the motor dissipate heat and run more efficiently and help motor last longer.

\section{Conclusion}

The recommendations described in this report are actions that require maintenance and installation of some energy saving devices that will reduce your overall energy bill. The following is a recommendation on human behavior and how important it is to reducing your energy needs. Consideration should be given of considering a grass roots energy efficiency program that involves staff that has structure and accountability. There is no capital expense to this type of approach to save energy. At the beginning of this report was a spreadsheet that can be used as the basis for this effort. It would require monitoring your energy use and sharing it with others throughout your facility. Some features about the facility is its construction and how there is minimal insulation in the walls. This is a difficult situation as it would be very expensive to fir out walls. Insulation could be added above the ceiling tiles such as 12 inch batt insulation which would add another R38 to your existing $\mathrm{R}$ values which are in the $\mathrm{R} 19$ range. This would save approximately 968 therms and $\$ 1,142.13$ per year. Overall the facility is well maintained and in good condition.

Gary V. Folchert., C.E.M., C.L.E.P

Commercial Business Account Consultant

Nebraska Public Power District

Office-402-644-3115

Cell-402-750-6663
\end{abstract}




\subsection{Turbine Technology Selection}

Wind turbine reliability is dependent largely on the particular machine model, how well it is designed, and the quality of manufacturing. A dramatic difference in newer turbine technology is the trend toward direct-drive turbines that eliminate the gearbox entirely and employ a low-speed, large-diameter synchronous generator. Another aspect of maintainability is modularity. Some systems incorporate multiple generators and gear units instead of one larger unit in order to make it easier to replace and eliminate the need for cranes. Instead, rigging is installed in the nacelle for maintenance purposes. In addition, power will not be completely lost if one unit is down and the other is still running. Maintainability advantages of modular configurations must be weighed against the increased potential for failures due to increased part count.

Figure 8.1-1 summarizes the US Market share for wind manufacturers from 2005 2007. GE Wind and Vestas have had the largest US Market share from 2006-2007. Figure 8.1-2 indicates the turbine sizes available from manufacturers in North America. Figure 8.1-3 list turbine and balance of plant manufacturing facilities in Nebraska and surrounding states.
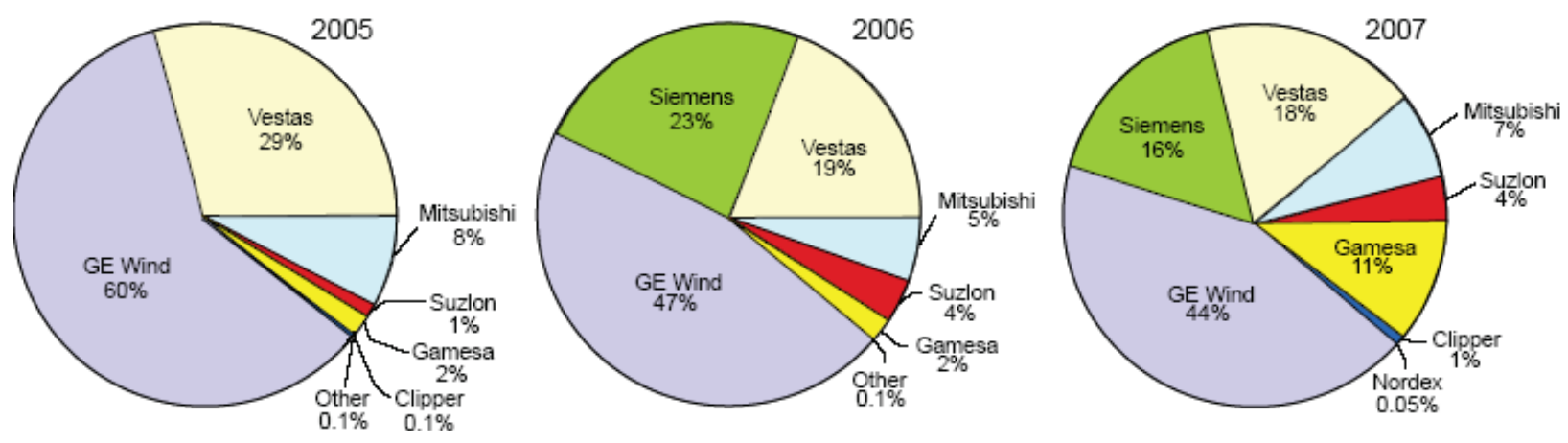

Source: AWEA project database

Figure 8.1-1, Annual US Market Share of Wind Manufacturers, by MW 2005-2007

\begin{tabular}{|l|l|}
\hline Manufacturer & Sizes Available in North America \\
\hline Siemens & $2.3 \mathrm{MW}+$ \\
\hline GE & $1.5 \mathrm{MW}, 2.5 \mathrm{MW}, 3.6 \mathrm{MW}$ \\
\hline Vestas & $600 \mathrm{~kW}, 1.65 \mathrm{MW}, 2.0 \mathrm{MW}, 3.0 \mathrm{MW}$ \\
\hline Mitsubishi & $600 \mathrm{~kW}, 1 \mathrm{MW}, 2 \mathrm{MW}$ \\
\hline Gamesa & $850 \mathrm{~kW}, 2 \mathrm{MW}$ \\
\hline Clipper & $2.5 \mathrm{MW}$ \\
\hline
\end{tabular}

Figure 8.1-2, Available Turbine Sizes by Suppliers in North America

\begin{tabular}{|r|l|l|l|}
\hline & \multicolumn{1}{|c|}{ Company } & \multicolumn{1}{c|}{ Location } & \multicolumn{1}{c|}{ Components } \\
\hline 2 & Acciona & West Branch, IA & $1.5 \mathrm{MW}, 3 \mathrm{MW}$ turbines \\
\hline 3 & Siemens & Fort Madison, IA & $2.3 \mathrm{MW}$ blades \\
\hline
\end{tabular}




\begin{tabular}{|r|l|l|l|}
5 & Knight \& Carver & Howard, SD & blades (testing "STAR" blade for low wind speeds) \\
\hline 9 & Hendricks Industries & Keokuk, IA & towers \\
\hline 10 & Katana Summit & Columbus, NE & towers \\
\hline 12 & Molded Fiberglass & Aberdeen, SD & 1.5 MW GE blades \& Nacelles \\
\hline 14 & TPI Composites & Newton, IA & 1.5 MW GE blades \\
\hline
\end{tabular}

Figure 6.1-3, Available Turbine Sizes by Suppliers in the Nebraska Area

The optimal turbine size for wind speeds in the 17.1-17.4 mph range at $80 \mathrm{~m}$ would be in the $1.5-1.65 \mathrm{MW}$ range. Three turbines in this size range are compared in Figure 8.1-4: GE Wind, AAER Wind and Vestas. AAER is a relatively new company and is US manufacturer of Fuhrlander wind turbines. There are a few main parameters to compare: cost, cut-in, cut-out and rated wind speeds, swept area. The cut-in wind speed for all three turbines are the same, however, the AAER will generate $1.65 \mathrm{MW}$ at $12 \mathrm{~m} / \mathrm{s}$ compared to Vestas at $13 \mathrm{~m} / \mathrm{s}$. The cut-in and cut-out wind speed is $20 \mathrm{~m} / \mathrm{s}$ for all of the turbines.

The current lead time for the turbines is approximately 12 months. Another time constraint for the project is having large enough cranes available for the installation.

\begin{tabular}{|c|c|c|c|}
\hline & GE & AAER & VESTAS \\
\hline & $1.5 x l e$ & 1.65 & N82 \\
\hline Rated capacity & $1,500 \mathrm{~kW}$ & $1,650 \mathrm{~kW}$ & $1,650 \mathrm{~kW}$ \\
\hline Cost & $\$ 2.3 \mathrm{M}$ & & $\$ 2.5 \mathrm{M}$ \\
\hline Cut-in wind speed, m/s & 3.5 & 3.5 & 3.5 \\
\hline Cut-out wind speed, $\mathrm{m} / \mathrm{s}$ & 20 & 20 & 20 \\
\hline Rated wind speed, m/s & 12.5 & 12 & 13 \\
\hline Rotor diameter, m & 82.5 & 80 & $82 m$ \\
\hline Swept area, sq m & 5,346 & 4,657 & 5,281 \\
\hline Hub heights, m & $80 \mathrm{~m}$ & $80 \mathrm{~m}$ & $80 m$ \\
\hline Class & $\begin{array}{c}\text { IEC: IIIb } \\
\text { (Vave }=8.0 \mathrm{~m} / \mathrm{s})\end{array}$ & $|-| I / I I-I I I$ & \\
\hline Power control & & & Active Stall \\
\hline Gearbox & & & Planet./hel. stages \\
\hline Generator & & Wound rotor ind. & Asyn. water cooled \\
\hline
\end{tabular}

Figure 6.1-4, Available Turbine Comparison

\subsubsection{HAWT versus VAWT Turbine Design}

The previous turbines are all horizontal axis wind turbines (HAWT). Another technology on the market is vertical axis wind turbines (VAWT). The main advantage of the HAWT is the increased efficiency in power production, and the smooth transfer of power from the rotor to the gearbox. Most VAWTs produce energy at approximately $50 \%$ of the efficiency of HAWTs mostly due to additional drag on the blades. There are some models designed to reduce this drag force. HAWTs are typically mounted on taller towers thus exposed to higher wind speeds and smaller ground footprints. However, 
they require tall cranes for set-up and all maintenance is performed at the top of a tower.

The disadvantages of the VAWT systems are that they typically operate near the ground where wind speeds are not as high; they produce wavy (sinusoidal) power pulses to drive mechanisms; they do not start themselves; and repair of the main bearing usually means having to take the whole machine apart. The advantages of the VAWT configuration are that the generator and gearbox can be housed on the ground, and even some distance away from the turbine; and that a VAWT is omni-directional and requires no yaw mechanism. VAWTs may be built at locations where taller structures are prohibited. VAWT blades are easily seen and avoided by birds.

\subsubsection{Operation and Maintenance}

Operations and maintenance (O\&M) costs compose a significant proportion of total generating costs, typically $70 \%$. Common component failures are associated with: gearbox bearings, generator bearings and windings, power electronics, gearbox torque arms, and pitch drive electronics. Wind Rotor blades and gearboxes are more subject to wear and tear than others. The price of a new set of rotor blades, a gearbox, or a generator is usually in the order of magnitude of $15-20 \%$ of the price of the turbine. The components of wind turbines are designed to last 20 years. The actual lifetime of a wind turbine depends both on the quality of the turbine and the local climatic conditions.

O \& M consists of both scheduled (preventive) and unscheduled (repair) maintenance costs, including expenditures for replacement parts, consumables, manpower and equipment.

Scheduled maintenance included:

- Periodic inspections of the equipment, oil and filter changes

- Calibration and adjustment of sensors and actuators

- Replacement of consumables such as brake pads and seals

- Housekeeping and blade cleaning

The specific tasks and their frequency are explicitly defined in the maintenance manuals supplied by the turbine manufacturer.

Operations can consist of:

- Scheduling site personnel

- Monitoring turbine operation

- Responding to turbine fault events

- Coordinating with the utility to address curtailment or outage issues

- Monitoring substation

- Correcting power factors

- Inventory management

- Coordinating site and maintenance services 
- Administering power purchase agreements

- Tracking warranty claims

- Collecting and interpreting performance data for the project

- Generating periodic reports

Costs associated with operations depend on the range of tasks assigned and on the size of the wind project. Supervisory Control and Data Acquisition (SCADA) systems can monitor turbines and/or control individual machines and power factors from a central location

For safety reasons, a two-person crew is generally required for any up-tower activity. Some replacements will require a crane to dismantle the drive train and several personnel in addition to the crane operator. Actual costs may vary due to accessibility to the turbine site, equipment availability, and wait time during high-wind conditions. The availability of cranes capable of lifting turbine components in the MW capacity range is limited due to high demands. Most replacement parts are supplied by the vendor such as power transmission, rotor components, controller, and power conversion equipment.

Indirect costs due to lost revenue depend on the total repair downtime and wind resource during the repair time. Cost reduction efforts should focus on improving component reliability and maintenance. Efforts should focus on:

- Critical component monitoring, such as, gearboxes, generators, power converters, etc

- Adequate training to ensure sufficient understanding of equipment and ability to characterize failure modes in order to prevent failures

- Failure analyses to reduce systematic problems

The portion of O\&M costs associated with unscheduled maintenance is the most difficult to predict and can be $30 \%$ to $60 \%$ of the total; this figure increases with time as failure rates increase and tend to decrease as the system size increase. Wind turbine system reliability is a critical factor in the success of a wind energy project. Poor reliability directly affects both the project's revenue stream through increased operation and maintenance $(\mathrm{O} \& \mathrm{M})$ costs and reduced availability to generate power due to turbine downtime.

It can be difficult in obtaining useful component failure data due to the rapid pace of development in wind turbine technology. In addition, many manufacturers source components from several sub-suppliers. In turn, the sub-supplier may incorporate internal revisions and model variations. Wind developers often utilize the following strategies:

- Quantify O\&M costs over time - gather operating histories from wind farms in order to gauge performance with other wind farms with similar conditions

- Develop a component reliability model 
- Identify high-risk components and understand failure modes. Trending reliability data over time can validate the effectiveness of preventive maintenance strategies to improve component reliability

8.7 2006 Denmark Wind Turbine Production and Maintenance Data

\begin{tabular}{|c|c|c|c|c|c|c|}
\hline kW & Mfc & No. of units & Avg. kWh & $\begin{array}{c}\text { Avg } \\
\mathrm{kWh} / \mathrm{m}^{2}\end{array}$ & $\begin{array}{c}\text { Avg } \\
k W h / k W\end{array}$ & CF \\
\hline 600 & Micon & 173 & 85,989 & 57.07 & 143.32 & 0.2 \\
\hline 600 & Vestas & 451 & 85,381 & 56.78 & 142.3 & 0.2 \\
\hline 600 & Nordtank & 68 & 79,947 & 55.41 & 133.24 & 0.18 \\
\hline 600 & NEG Micon & 195 & 88,028 & 54.88 & 146.71 & 0.2 \\
\hline 600 & Wincon & 8 & 86,741 & 54.54 & 144.57 & 0.2 \\
\hline 600 & Wind World & 87 & 71,808 & 51.71 & 119.68 & 0.16 \\
\hline 600 & Bonus & 232 & 74,681 & 49.93 & 124.47 & 0.17 \\
\hline 600 & Nordex & 54 & 70,059 & 47.88 & 116.76 & 0.16 \\
\hline 600 & Enercon & 149 & 70,372 & 46.34 & 117.29 & 0.16 \\
\hline 600 & REpower & 20 & 83,190 & 45.22 & 138.65 & 0.19 \\
\hline 600 & GE Wind & 5 & 75,114 & 45.2 & 125.19 & 0.17 \\
\hline 600 & Tacke & 126 & 66,902 & 43.26 & 111.5 & 0.15 \\
\hline 600 & DeWind & 131 & 68,809 & 38.24 & 114.68 & 0.16 \\
\hline 600 & Sudwind & 5 & 61,180 & 36.81 & 101.97 & 0.14 \\
\hline 600 & Jacobs & 14 & 62,966 & 35.12 & 104.94 & 0.14 \\
\hline 600 & BWU & 28 & 60,666 & 34.53 & 101.11 & 0.14 \\
\hline 750 & NEG Micon & 706 & 100,360 & 57.73 & 133.81 & 0.18 \\
\hline 750 & Micon & 50 & 93,676 & 56.22 & 124.9 & 0.17 \\
\hline 750 & Wind World & 12 & 87,464 & 41.73 & 116.62 & 0.16 \\
\hline 750 & BWU & 5 & 55,235 & 30.02 & 73.65 & 0.1 \\
\hline
\end{tabular}




\begin{tabular}{|c|c|c|c|c|c|c|c|c|c|c|c|c|c|c|c|c|c|c|c|}
\hline & \multicolumn{2}{|c|}{ Maintenance } & \multicolumn{2}{|c|}{ Weather } & \multicolumn{2}{|c|}{ Grid break } & \multicolumn{2}{|c|}{ Wear } & \multicolumn{2}{|c|}{ Failure } & \multicolumn{2}{|c|}{ Not Stated } & \multicolumn{2}{|c|}{$\begin{array}{c}\text { Scheduled } \\
\text { stop }\end{array}$} & \multicolumn{2}{|c|}{$\begin{array}{c}\text { Only stop hrs } \\
\text { reported }\end{array}$} & \multicolumn{2}{|c|}{ Total } & \multirow[t]{2}{*}{$\%$} \\
\hline & No. & Hours & No. & Hours & No. & Hours & No. & Hours & No. & Hours & No. & Hours & No. & Hours & No. & Hours & No. & Hours & \\
\hline & 374 & 3,095 & 18 & 396 & 130 & 7,548 & 23 & 419 & 5 & 466 & 86 & 499 & 47 & 6236 & 13 & 77 & 696 & 18,736 & $9.6 \%$ \\
\hline & 23 & 374 & 5 & 1797 & 0 & 0 & 74 & 2,215 & 15 & 3,777 & 4 & 75 & 0 & 0 & 4 & 156 & 125 & 8,394 & $4.3 \%$ \\
\hline & 0 & 0 & 2 & 11 & 0 & 0 & 11 & 175 & 0 & - & 0 & 0 & 1 & 1 & 0 & 0 & 14 & 187 & $0.1 \%$ \\
\hline \multirow[t]{2}{*}{$\underline{z}$} & 0 & 0 & 0 & 0 & 0 & 0 & 3 & 55 & 6 & 123 & 0 & 0 & 0 & 0 & 0 & 0 & 9 & 178 & $0.1 \%$ \\
\hline & 0 & 0 & 0 & 0 & 0 & 0 & 68 & 802 & 21 & 501 & 0 & 0 & 0 & 0 & 0 & 0 & 89 & 1,303 & $0.7 \%$ \\
\hline \multirow[t]{4}{*}{ g } & 0 & 0 & 0 & 0 & 0 & 0 & 2 & 248 & 1 & 543 & 1 & 20 & 0 & 0 & 1 & 0 & 5 & 811 & $0.4 \%$ \\
\hline & 15 & 26 & 0 & 0 & 0 & 0 & 13 & 177 & 19 & 1,197 & 8 & 31 & 2 & 4 & 2 & 3 & 59 & 1,438 & $0.7 \%$ \\
\hline & 3 & 3 & 1 & 2 & 0 & 0 & 30 & 353 & 18 & 4,373 & 4 & 53 & 0 & 0 & 0 & 0 & 56 & 4,784 & $2.4 \%$ \\
\hline & 2 & 1 & 3 & 3 & 0 & 0 & 27 & 475 & 17 & 706 & 13 & 41 & 1 & 4 & 1 & 20 & 64 & 1,250 & $0.6 \%$ \\
\hline \multirow[t]{2}{*}{ r } & 0 & 0 & 0 & 0 & 0 & 0 & 2 & 16 & 3 & 113 & 0 & 0 & 0 & 1 & 0 & 0 & 5 & 130 & $0.1 \%$ \\
\hline & 0 & 0 & 4 & 32 & 7 & 24 & 29 & 277 & 5 & 139 & 5 & 31 & 0 & 0 & 1 & 21 & 51 & 524 & $0.3 \%$ \\
\hline \multirow[t]{7}{*}{$\underline{m}$} & 14 & 27 & 4 & 9 & 3 & 21 & 97 & 1,603 & 63 & 2,278 & 15 & 120 & 1 & 0 & 2 & 1 & 199 & 4,059 & $2.1 \%$ \\
\hline & 0 & 0 & 0 & 0 & 0 & 0 & 19 & 373 & 35 & 2,159 & 0 & 0 & 0 & 0 & 0 & 0 & 54 & 2,532 & $1.3 \%$ \\
\hline & 0 & 0 & 22 & 52 & 0 & 0 & 32 & 499 & 8 & 175 & 3 & 29 & 0 & 0 & 1 & 11 & 66 & 766 & $0.4 \%$ \\
\hline & 14 & 39 & 1 & 22 & 5 & 27 & 23 & 165 & 7 & 59 & 44 & 147 & 3 & 17 & 1 & 0 & 98 & 476 & $0.2 \%$ \\
\hline & 17 & 133 & 6 & 71 & 1 & 3 & 11 & 137 & 6 & 659 & 5 & 13 & 0 & 0 & 6,283 & 149,503 & 6,329 & 150,519 & $76.8 \%$ \\
\hline & 462 & 3,698 & 66 & 2,395 & 146 & 7,623 & 464 & 7,989 & 229 & 17,268 & 188 & 1,059 & 55 & 6,263 & 6,309 & 149,792 & 7,919 & 196,087 & $100.0 \%$ \\
\hline & & $1.9 \%$ & & $1.2 \%$ & & $3.9 \%$ & & $4.1 \%$ & & $8.8 \%$ & & $0.5 \%$ & & $3.2 \%$ & & $76.4 \%$ & & & \\
\hline
\end{tabular}




\subsection{Wind Turbine Suppliers and Resources}

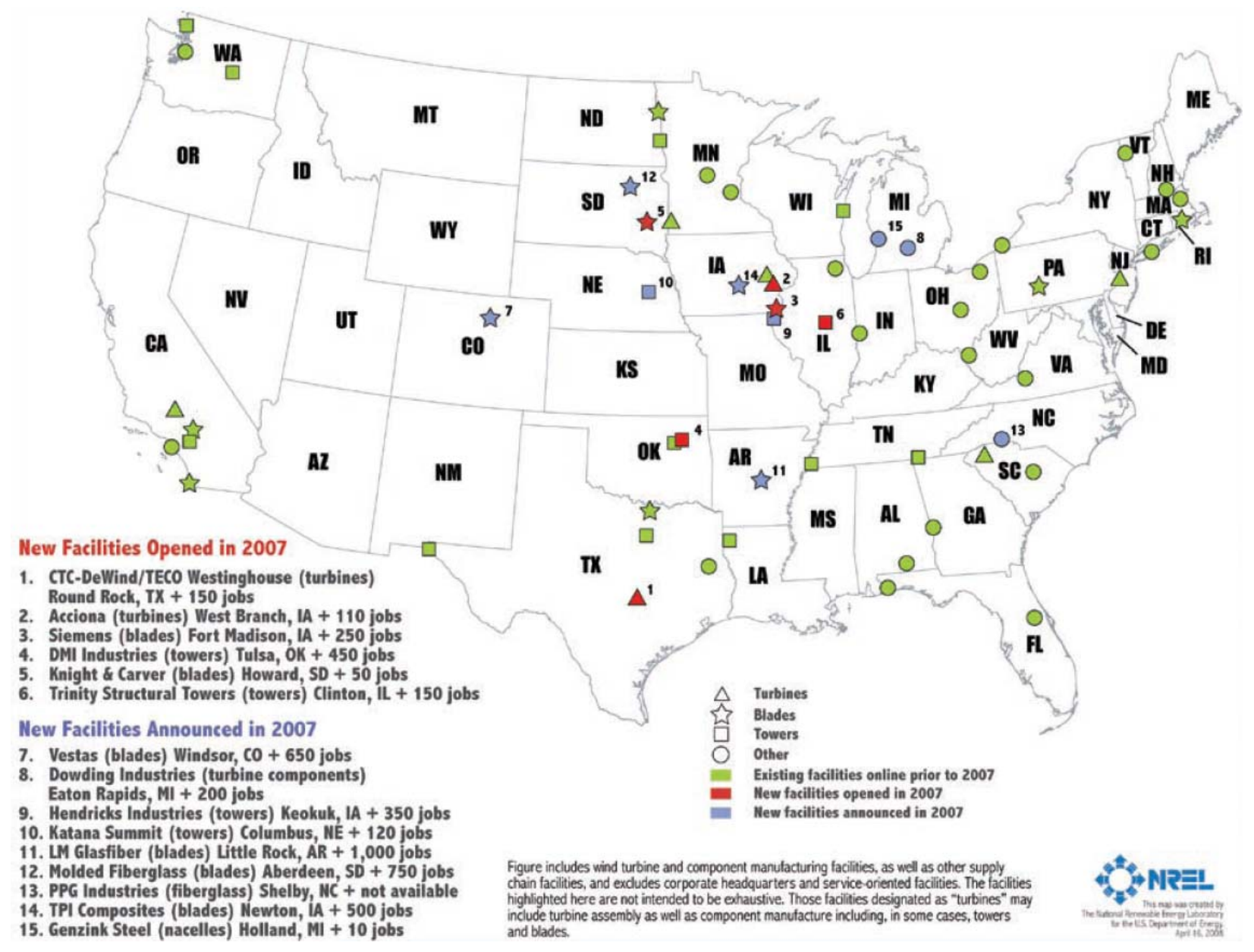

Wind Energy Services Company

www.usawindenergyservices.com

1200 West Sycamore Street

Independence, KS 67301

P: (877) FIX-BLADE and (620) 331-1900

F: $\quad$ (620) 331-1905

http://www.windpower.org/en/stat/unitac3c.htm

http://www.windstats.com/uploads/media/WS Sample 19-3.pdf 


\subsection{Wind Turbine Manufacturing Facilities Near Winnebago}
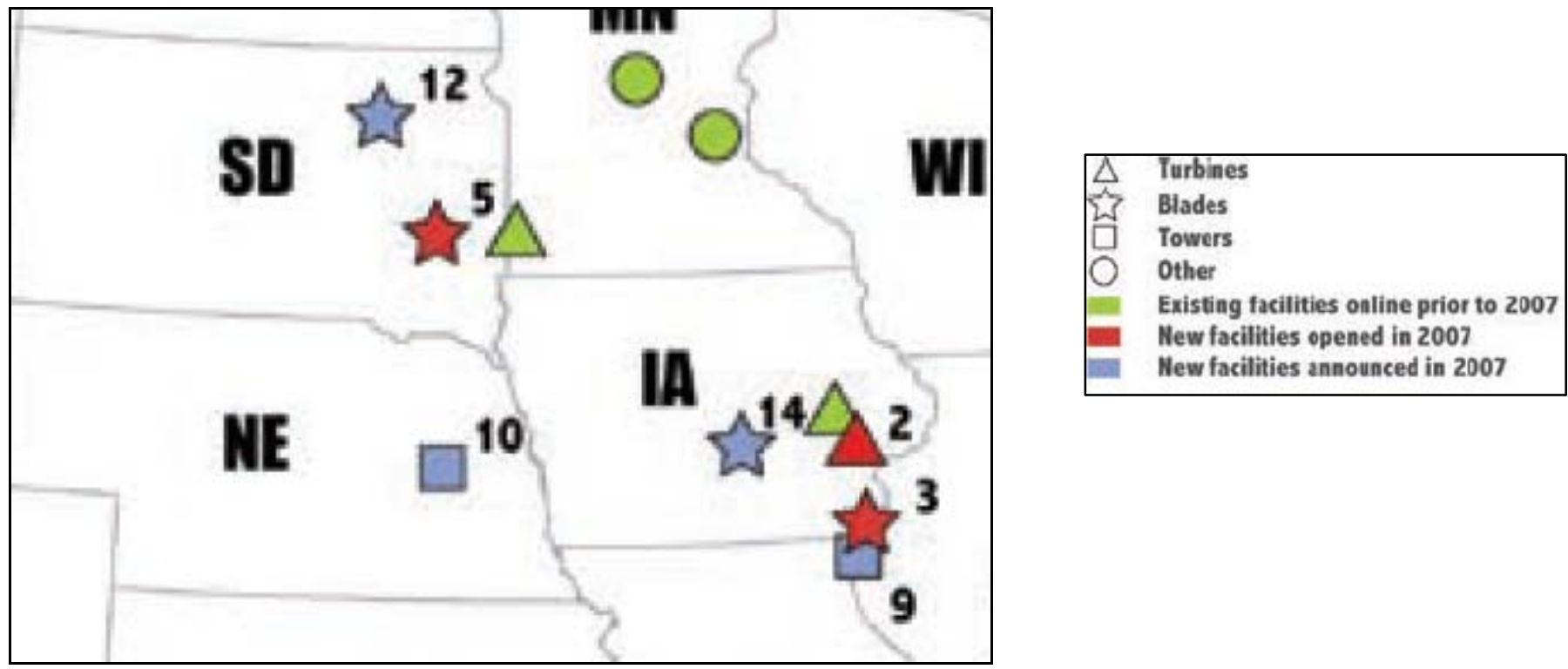

\begin{tabular}{|r|l|l|l|}
\hline \multicolumn{1}{|c|}{$\#$} & \multicolumn{1}{|c|}{ Company } & \multicolumn{1}{c|}{ Location } & \multicolumn{1}{c|}{ Components } \\
\hline 2 & Acciona & West Branch, IA & 1.5 MW, 3 MW turbines \\
\hline 3 & Siemens & Fort Madison, IA & $2.3 \mathrm{MW}$ blades \\
\hline 5 & Knight \& Carver & Howard, SD & blades (testing "STAR" blade for low wind speeds) \\
\hline 9 & Hendricks Industries & Keokuk, IA & towers \\
\hline 10 & Katana Summit & Columbus, NE & towers \\
\hline 12 & Molded Fiberglass & Aberdeen, SD & $1.5 \mathrm{MW}$ GE blades \& Nacelles \\
\hline 14 & TPI Composites & Newton, IA & $1.5 \mathrm{MW}$ GE blades \\
\hline
\end{tabular}




\subsection{Crane Equipment Quote}

\section{crame RIENTEAL \& RIGGIANG}

Date: October 1, 2009

To: Red Mountain

PHONE: 602-516-7540

Job location: Sloan, IA

Specification: Supply a crane for a wind turbine assembly.

Equipment needed: Hyd Truck Crane

$\$ 10,500.00$ Mobilization In

$\$ 700.00$ Hourly ST premium for crane with CCO Certified Operator (8 $\mathrm{hr} \mathrm{min}$ )

$\$ 25.00 \quad$ Fuel Surcharge per operated hour

$\$ 150.00$ Hourly ST premium for Assist Crane with CCO Certified Operator

$\$ 15.00 \quad$ Fuel Surcharge per operated hour

$\$ 10,500.00$ Mobilization out

$\$ 18.00 \quad$ Hourly OT premium - all hrs over 8 and all Saturday per man

\$36.00 Hourly DT premium - Sundays and Holidays per man

$\$ 100.00$ Subsistence per man per day

$\$$

Permit costs

7:30 am to $4: 00 \mathrm{pm}$ are our straight time hours with a $1 / 2$ hour lunch.

Site conditions must be suitable for assembly and disassembly and to perform work.

All crane rentals are subject to availability

Quoted prices are good for thirty (30) days.

Any applicable taxes are additional

Price does not include mats for soft ground conditions. 
Crane Rental \& Rigging assumes NO LIABILITY for site conditions, preparation and or damage

No rigging is included in this quote

Rental rates are based on single shift usage

Weather delays billed at $70 \%$ of hourly rate

All operators are CDL Certified and CCO Tested.

All bare rental rates do not include operator, oiler, fuel, and maintenance.

\section{TERMS \& CONDITIONS TO PROPOSAL}

- Net 30 days, no retainage. Interest may be charged at the rate of $1 \frac{1}{2} \%$ per month (18\% annual rate) on past due accounts after 30 days from the invoice date. In addition, you agree to pay all cost, in effort to collect past due accounts.

- Overtime rates shall apply after eight hours, through lunch time, and outside of normal working hours.

- Equipment subject to availability. No warranties have been made with respect to the capacity of the machinery or to the fitness for a particular purpose unless otherwise expressed in proposal.

- All hoisting will be done within the confines of the load chart.

- Routine maintenance (greasing) time to be allowed during normal work time, or may be billed at $1 / 2 \mathrm{hr}$. overtime for operator per day.

- Damage to our equipment by others on site will be billed at repair cost.

- Damage to our rigging due to misuse will be billed at replacement cost.

- Suitable access roads and lay-down areas shall be provided into the site and work area to permit the equipment to approach and leave the work area under its own power. A clear area for the unrestricted operation and dismantling of the equipment shall also be provided.

- The temporary removal or disconnection of overhead obstruction and wires must be done prior to job start.

- You acknowledge that any driveways, parking lots, sidewalks, curbs, or underground utilities, paving, etc. in the path the equipment uses to do its work, and all other surfaces or structures over which equipment is to be operated on or adjacent to are of sufficient strength to withstand the weight of this equipment including placement of outriggers and agree to accept responsibility for any damage.

- Our on-hook liabilities are limited to one million dollars. Additional insurance coverage can be provided at cost plus $5 \%$.

- Terms and conditions to proposal enclosure.

Thank you for the opportunity to quote this project. If you have any questions, please feel free to contact me.

Sincerely,

Jon Danke 


\subsection{Woodbury Electric Rates}

A. Distributed Generation Purchase Rate:

Per Exhibit A, Part 1 for consumer-owned distributed generation located on a Class A Member's distribution system that has a committed output level of not less than $150 \mathrm{~kW}$ and not more than $5 \mathrm{MW}$. I PREVIOUSLY IDENTIFIED THIS RATE FOR THE CASINO WIND GENERATOR, HOWEVER, this is not available for wind generation, because the qualifications include being dispatchable Wind generation is not dispatchable

B. Qualifying Facility Generation Purchase Rate:

Per Exhibit A, Part 2 for Qualifying Facilities according to the Public Utility Regulatory Policies Act of 1978 (PURPA).

C. Small Renewable Energy Purchase Rate:

Per Exhibit A, Part 3 for consumer-owned wind, solar or biomass generation located on a Class A Member's distribution system that has a generator nameplate capacity of $150 \mathrm{~kW}$ or less for a single site. If the Casino wind generator is $600-700 \mathrm{kw}$ this rate would not apply because of size qualifications, larger than $150 \mathrm{KW}$.

D. Commercial Wind Energy Purchase Rate:

Per Exhibit A, Part 4 for commercial size consumer-owned generation facilities located on a Class A Member's distribution system or NIPCO's transmission system that has a generator nameplate capacity of not less than $150 \mathrm{~kW}$ and not more than $20 \mathrm{MW}$. This rate would apply to the Casino if their wind generator is in the 600-700 kw size. We have listed Exhibit A Part 4 Commercial Wind Energy Purchase Rate below.

Be aware that Basin Electric and NIPCO may increase this rate a total of $4 \mathrm{mills} / \mathrm{kwh}$.

Section B, 1 Wind Energy Payment Rate, identified below, may be increased by 4 mills/kwh $(2 \mathrm{mills} / \mathrm{kwh}$ from Basin Electric Power Cooperative and $2 \mathrm{mills} / \mathrm{kwh}$ from NIPCO). This causes the payment to be increased in 2009 from $40.00 \mathrm{mills} / \mathrm{kwh}$ to 44.00 mills/kwh and likewise each year following.

This rate would apply to a $600-700 \mathrm{KW}$ wind generator at the casino. 


\section{Policy 8-3 \\ EXHIBIT A - Part 4 \\ Commercial Wind Energy Purchase Rate}

This Power Purchase Rate is available to consumers of Class A Members of NIPCO (Member) that meet the following Eligibility Criteria. The objective of this rate is to specify the qualification criteria and define the rate NIPCO will pay for delivery of wind energy from commercial size consumer-owned wind generation facilities located on the member distribution systems.

A. Eligibility Criteria

1. The wind energy generation must be located on the Member's distribution system and be within the WAPA Upper Missouri control area and directly connected to a member distribution system which is directly served from the Integrated System.

2. The total generator nameplate capacity of the wind energy generator(s) qualifying for this rate may not be less than $150 \mathrm{~kW}$, nor exceed a total of 20,000 kW for a single site.

3. Wind energy purchased under this rate may not receive payment pursuant to NIPCO's policy for administering the Public Utility Regulatory Policies Act of 1978 (PURPA).

4. $100 \%$ of the wind energy output produced by the wind facility shall be delivered to and purchased under this Rate from NIPCO; there shall be no net metering. Such purchased power shall be delivered by NIPCO to the Member at the site and all delivered quantities shall be added to NIPCO's monthly demand and energy deliveries prior to determining NIPCO billing under Policy \#8-1.

5. The memberlconsumer shall be responsible for any and all costs of accepting and distributing the generation output for resale to their member load and NIPCO shall not be responsible for any incremental transmission expenses as a result of this power purchase.

6. The member/consumer shall hold NIPCO harmless from any liability to itself or third parties arising out of the operation of the wind energy facility and the member/consumer shall be responsible for all costs in ensuring the wind energy can be connected to, or isolated from, the electrical grid.

7. All wind energy purchased under this rate shall include any environmental attributes (renewable energy credits) associated with the environmental character of the generation. Basin Electric shall receive ownership of those wind energy credits and shall have the right to remarket the wind energy credits. For the purpose of this rate, environmental attributes and/or wind energy credits shall not include Federal income tax credits for wind energy that are accruable to the owner of the wind energy facility. The member/consumer shall annually provide a completed, signed copy, Renewable Energy Certificate, to Basin Electric prior to receiving any payments.

The member/consumer shall be allowed a one-time election at the time of rate application to maintain all environmental attributes (renewable energy credits) associated with environmental character of generation. If the member/consumer chooses to maintain these environmental attributes, NIPCO's Wind Energy Payment rate shall be reduced by 8.00 mills/kWh.

8. The attached Wind Energy Purchase Application must be completed and executed by the member/consumer requesting NIPCO to purchase wind energy pursuant to this rate. 
9. NIPCO shall review and approve or disapprove the use of this rate and qualification term for each wind energy purchase.

10. This rate will be made available only to the extent the cumulative annual quantity of all renewable energy projected by Basin Electric to be purchased under this Rate for each upcoming year does not exceed an estimated total of 90,000 MWh per year.

11. A qualified facility has a one-time option to either 1 ) receive the Commercial Wind Energy Payment Rate as it may change over the time of the Commitment Term, or 2) lock in the Commercial Wind Energy Payment Rate in effect at the time of the application.

12. The maximum Commitment Term shall not exceed fifteen (15) years and must be approved by NIPCO.

13. The Member agrees that $100 \%$ of the wind energy payment from NIPCO to the Member shall be passed on to the owner or operator of the wind energy generator.

14. Metering and remote control requirements listed below must be met to qualify for the Wind Energy Payment.

15. The application of this rate and purchase of wind energy must be allowed by state law, without subjecting NIPCO, the Member or the consumer to additional regulation and/or obligation. In the event state law results in the additional regulation or obligations to any party, qualification under this rate is null and void and all parties are released from the obligations of this rate irrespective of the Commitment Term.

B. Payment Rate

1. Wind Energy Payment Rate: For generation qualifying for this Rate, NIPCO will pay the following Payment Schedule during the Commitment Term if the member/consumer desires to lock in these Wind Energy Payment Rates for its Commitment Term. Otherwise NIPCO will pay the current Wind Energy Payment Rate in effect for that year. The Wind Energy Payment Rate may be revised upward or downward by the Basin Electric Board of Directors during the Commitment Term. (Exception: Those purchase agreements with rates defined for the Commitment Term will receive payment for the term of that agreement in accordance with the Payment Schedule in effect on the date the contract was established.)

Payment

$\begin{array}{cc}\text { Year } & \text { Mills/kWh } \\ 2009 & 40.00 \\ 2010 & 40.60 \\ 2011 & 41.21 \\ 2012 & 41.83 \\ 2013 & 42.46 \\ 2014 & 43.10 \\ 2015 & 43.75 \\ 2016 & 44.41\end{array}$




$\begin{array}{ll}2017 & 45.08 \\ 2018 & 45.76 \\ 2019 & 46.45 \\ 2020 & 47.15 \\ 2021 & 47.86 \\ 2022 & 48.58 \\ 2023 & 49.31 \\ 2024 & 50.05\end{array}$

2. Wind Energy Matching Payment. Basin Electric may, at its discretion, provide a Wind Energy Matching Payment of up to $2.00 \mathrm{mills} / \mathrm{kWh}$ to NIPCO, if NIPCO pays locally owned generation qualifying for this rate, a premium payment over and above the above noted Wind Energy Payment. NIPCO agrees to pass this Wind Energy Matching Payment along to the owner of the generation.

3. Billing: Payment for Wind Energy purchase shall be in the form of a credit on the Member's monthly power bill.

C. Metering and Remote Control Requirements:

1. The consumer-owner shall be responsible for all metering costs. The meter shall be electronically read by the Member and/or NIPCO.

2. Metering for the consumer-owned wind energy facility shall be such that all power delivered to the grid from the consumer-owned generation shall be metered separately from power delivered from the Member to the consumer. The meter measuring power delivered to the consumer shall not permit reduction of measured power already delivered to the Member during periods when the wind energy generation exceeds the consumer's demand (the meter may not run backwards).

3. Thirty-minute time registration demand and energy metering must be installed for all facilities.

4. Continuous real-time generation data must be provided for all facilities with a nameplate rating of $750 \mathrm{~kW}$ or larger.

5. All meters shall be tested and calibrated as required by the Wholesale Power Contract between NIPCO and the Member.

6. In the event of a metering equipment malfunction, NIPCO shall be the sole determinant of the estimated amounts of power and energy delivered to NIPCO. That estimated amount shall also be added to NIPCO's monthly demand and energy deliveries prior to determining NIPCO billing under Policy \#8-1.

D. Interconnection Provisions:

1. Interconnection of the wind project to the electrical grid shall be the responsibility of the member/consumer. To qualify for this rate, all governmental, regulatory and electrical grid transmission provider requirements must be met. At the memberlconsumer's request and expense, NIPCO will arrange for the necessary applications, presentations, and engineering transmission studies to apply for interconnection approvals. Such service will 
be performed at cost, with no markup. Prepayment of estimated costs shall be required, with a final adjustment of actual costs debited or credited at the completion of the interconnection request process. NIPCO shall exert a good faith and diligent effort to obtain electrical grid interconnection approvals, but shall be held harmless for any actions or failure to such action.

2. NIPCO shall be responsible to ensure all substations receiving energy deliveries from wind energy facilities qualifying under this Rate have sufficient capability to receive the energy deliveries. 


\subsection{Woodbury Electric Tariff}

WOODBURY COUNTY RURAL ELECTRIC COOPERATIVE

$\underline{\text { Rates }}$

Electric Tariff

Original Sheet

No. 67

Filed with the IUB

Cancels

Revised Sheet

No.

Rate Designation: Standby Rate

N

Class of Service: Three Phase Service

Service Area: Within the rate areas of Woodbury, Ida, Plymouth, Cherokee, and Monona

Counties, Iowa.

Availability

Standby service is a component of power supply under the all-requirements power supply contract between Northwest lowa Power Cooperative (NIPCO) and Woodbury REC, its Class A member (Member). The use of this rate is mandatory in any instance wherein a Woodbury REC Member consumer has elected to self-generate some or all of its power requirements and requests standby service. This rate reflects the anticipated cost of providing standby service.

\section{Eligibility Requirements}

1. The member/consumer shall provide documentation to Woodbury REC and NIPCO stating the maximum capacity and anticipated reliability of the power source for which standby service is required. The member/consumer shall also provide documentation to Woodbury REC and NIPCO identifying the total capacity Woodbury REC and NIPCO will be required to supply when the retail consumer's power source is not available. This value, defined as the Requested Standby Capacity, shall not exceed the capacity rating of the retail consumers own power source and shall not be less than the consumer's peak load served by the power source.

2. The member/consumer may not use the power source for which standby service is requested for load management purposes to minimize the Woodbury REC's power purchases from NIPCO.

3. This rate is not intended to be utilized as a full-service rate.

4. The minimum magnitude of standby service provided under this rate schedule is 150 $\mathrm{kW}$.

5. Standby Capacity will be provided on an annual basis only.

6. If a retail consumer has a single or multiple power sources at the same site and this rate is utilized to provide backup service to all, or a portion of the multiple sources, each source must be individually metered and Woodbury REC and NIPCO's energy deliveries 
to the Member in the event of the consumer loss of power source shall be based on the individual meters for the source associated with the loss of power, unless otherwise agreed by Woodbury REC and NIPCO. This service, and the associated load regulation, will only be provided for those individual power sources identified in the Standby Purchase Application.

Issued: July 22, 2008 2008 Issued by: /s/ Tom Ryan
Title: $\underline{\text { President }}$
Proposed Effective Date: August 22. Effective:

WOODBURY COUNTY RURAL ELECTRIC COOPERATIVE

Electric Tariff

Rates

$\underline{67 A}$

Filed with the IUB

Cancels

Original Sheet No.

-

2008 Rate

1. Coincident Demand Rate: $\$ 9.47$ per kilowatt month (\$5.50 Basin Electric Standby Rate and \$2.39 NIPCO Network Transmission Tariff and \$1.58 Woodbury REC per Coincident kilowatt).

2. Non Coincident Demand Rate: $\$ 9.50$ per kilowatt month.

3. Energy Rate: The daily on-peak index for firm deliveries on a daily basis (identified at the time of application), plus a NIPCO $10 \%$ administrative fee, plus a Woodbury REC $20 \%$ for losses and margin.

4. Alternate Energy Rate: Amount established in January of each year reflecting Basin Electric's past year's average purchase power price and/or surplus power sales value plus a NIPCO ten percent administrative fee, plus a Woodbury REC $20 \%$ for losses and margin.

\section{Customer Charge: $\$ 220$ per month.}

Non-dispatchable Resources

A member/consumer shall have a one-time option (prior to utilizing this Standby Rate) to elect the Alternate Energy Rate for a non-dispatchable resource of less than $1 \mathrm{MW}$ owned by a member cooperative retail consumer. 


\section{Billing Mechanism}

1. The meter readings required hereunder shall be adjusted for losses to the Basin Electric point of delivery. NIPCO shall determine the appropriate loss factors in accordance with Basin Electric's loss policy for incentive rates.

2. The demand charge for each billing period for standby service provided under this rate shall be the Demand Rate times the Requested Standby Capacity amount, adjusted to the normal Basin Electric point of delivery.

3. If standby service is provided at the time of NIPCO's monthly coincident billing peak, Woodbury REC's Base Rate billing demand shall be reduced by the lesser of 1) the magnitude of the load receiving standby service or 2) the Requested Standby Capacity amount.

Issued: July 22, 2008

2008

Issued by: /s/ Tom Ryan
Proposed Effective Date: August 22,

Title: $\underline{\text { President }}$
Effective:
WOODBURY COUNTY RURAL ELECTRIC COOPERATIVE

Electric Tariff

$\underline{67 \mathrm{~B}}$

Filed with the IUB
Cancels $\underline{\text { Rates }}$

Original Sheet No. 
1. The member/consumer shall be responsible for all metering costs and shall separately meter the generator output for which Standby Service is required, and $100 \%$ of the consumer load at that site.

2. Thirty-minute time registration demand metering must be installed by the member/consumer. All meters shall be tested and calibrated as required by the Wholesale Power Contract between NIPCO and Woodbury REC. The meter shall be electronically read by Woodbury REC and/or NIPCO.

3. In the event of metering equipment malfunction, Basin Electric shall be the sole determinant of billing meter quantities.

Issued: July 22, 2008

2008

Issued by: /s/ Tom Ryan
Proposed Effective Date: August 22,

Title: $\underline{\text { President }}$
Effective: 


\subsection{Additional lowa Resources}

Northwest lowa Power Cooperative (NIPCO)

Goal is to offer a variety of development services to encourage existing business expansion, to foster new business start-ups, and to attract business locations. ${ }^{2}$

Financial Assistance

$>$ Loans

$>$ Interest Buy Downs

$>$ Grant Applications

$>$ Research Financing Options

Technical Assistance

- Permitting Assistance

- Manufacturing Assistance

- Infrastructure Development
o Buildings
o Sites
o Utilities
o Roads

Woodbury County Rural Electric Cooperative

Woodbury County Rural Electric Cooperative provides energy audits for our customers at no charge. To schedule a free energy audit, please call the Woodbury County REC office at (712)873-3125 or (800)469-3125. ${ }^{3}$

\section{lowa - Net Metering \& Interconnection}

Limit on System Size: $500 \mathrm{~kW}$. There is no explicit limit on either the size of a net-metered system or on total enrollment in the IUB's subrule. However, separate rule waivers have allowed MidAmerican Energy and IPL to limit individual systems to $500 \mathrm{~kW}$.

Utilities Involved: Investor-owned utilities (MidAmerican Energy, Interstate Power and Light) Authorities: Iowa Code § 476.41 et seq., IAC § 199-15.11(5)

\footnotetext{
${ }^{2}$ http://www.nipco.coop/Services/Ecodev/index.html

${ }^{3}$ http://www.woodburyrec.com/information/usage/audit.html
} 
Iowa's statutes do not explicitly authorize the lowa Utilities Board (IUB) to mandate net metering, but this authority is implicit through the board's enforcement of PURPA and lowa Code $\S 476.41$ et seq. Net metering is available to all customer classes of lowa's two investorowned utilities -- MidAmerican Energy and Interstate Power and Light (IPL). Although lowa's net-metering subrule requires utilities to purchase customers' net excess generation (NEG) at the utility's avoided-cost rate, subsequent rule waivers allow MidAmerican Energy and IPL customers to carry NEG (as a kWh credit) forward for use in future months. ${ }^{4}$

The lowa Supreme Court has ruled in favor of an lowa family who have been pursuing with their local utility, Midland Power Cooperative (one of Central lowa Power Cooperative's members), the ability to connect their $65-\mathrm{kW}$ wind system with a net metering tariff. ${ }^{5}$ In its ruling, the state Supreme Court affirmed the district court's finding that net metering is to be used in settling accounts between the utility company and its cogenerating customers. It ruled that separate billing is inconsistent with the interpretation of the Public Utility Regulatory Policy Act (PURPA) and federal regulations by the Federal Energy Regulatory Commission (FERC) and the lowa Utilities Board.

lowa allows net metering for renewable energy systems, but no uniform interconnection standards are currently in place for either small renewables or larger distributed generation. To remedy this, the lowa Department of Natural Resources (DNR) has established a process to establish such standards. As a first step the DNR will commission a comprehensive report assessing interconnection barriers and potential solutions specific to lowa. ${ }^{6}$

Existing language in lowa's enabling net metering legislation does limit the discretion of utilities to impose onerous interconnection requirements. The law states that where systems meet the relevant requirements of the National Electrical Code (NEC), the Institute of Electrical and Electronics Engineers (IEEE), and Underwriters Laboratories (UL), utilities cannot require system owners to comply with additional safety or performance standards, perform or pay for additional tests, or purchase additional liability insurance.

Contact: John Pearce, lowa Utilities Board

Phone: (515) 281-5679

E-Mail: John.Pearce@lowa.gov

Web site: http://www.state.ia.us/government/com/util/index.html

\footnotetext{
${ }^{4}$ http://www.dsireusa.org/library/includes/incentive2.cfm?Incentive_Code=IA02R\&state=IA\&CurrentPageID=1

${ }^{5}$ http://healthandenergy.com/net_metering_in_iowa.htm

${ }^{6}$ http://www.awea.org/smallwind/iowa.html
} 


\section{Energy Efficiency Testing and Demonstration Facility - Energy Resource Station}

Grant \#: 94-10-02

Principal Investigator: Mark Baethke

Organization: Des Moines Area Community College

Technical Area: Energy Efficiency

\section{Agreement of Support}

DMACC will facilitate required equipment purchases and installation services including interaction with construction management firms and payment of contractor/vendor invoices. DMACC will review and update relevant professional services agreements for management services related to the operation of the Energy Resource Station. DMACC will perform routine site inspections. 


\subsection{Nebraska Game and Parks Commission Review}

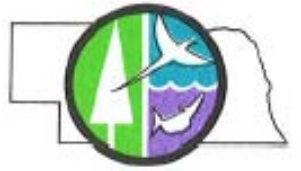

November 14, 2008

Louis C. Houghton, Jr.

Winnebago Tribal Council

Winnebago, NE 68071

Re: Wind Farm project, Winnebago, NE (Thurston County)

Dear Mr. Houghton

Please make reference to your request dated October 8, 2008 requesting information about designated threatened or endangered species or their habitats for the proposed sites of wind development located in Thurston County, Nebraska. As we understand it, the project proponent is in the process of determining which location is the most suitable for a wind resource development. This letter is in response for your request for information regarding potential impacts to species or habitats in these two locations.

The Nebraska Natural Heritage Program tracks occurrences of "at-risk" species and native plant communities within the state. "At-risk" species and communities are defined as those which are declining in Nebraska, declining globally or unique to Nebraska. State listed threatened and endangered species are among those tracked by the Natural Heritage Program. All at-risk species and communities are considered a valuable state resource worthy of ensuring continued existence in Nebraska.

Wind-generated energy is widely considered environmentally friendly as it is renewable and produces no emissions. Potential consequences of global warming warrant investigation and production of alternative energy sources. However, construction and operation of wind turbines can be detrimental to wildlife populations and has been recognized for decades (Schmidt et al 2003). Fatal bird collisions are well documented, but vary widely in numbers and severity (Erickson et al 2001). Studies suggest that raptors are particularly susceptible to collisions (Hoover and Morrison 2005). In addition to collisions, Wind Resource Areas (WRA) can reduce available habitat for grassland nesting birds (Leddy et al 1999), by fragmenting available habitat. In addition to birds, incidents of substantial mortality has been reported for bats (Kerlinger and Kerns 2004). Research suggests that fatalities are primarily migratory bats during the fall migration (Johnson et al. 2004, Reynolds 2006) rather than resident populations.

Interim guidelines to avoid and minimize wildlife impacts from wind turbines have been produced by the U.S. fish and Wildlife Service and are available online http://www.fws.gov/habitatconservation/wind.htm. This guidance is provided to assist the wind energy industry in avoiding or minimizing impacts to wildlife and their habitats. Each situation is unique, therefore avoiding impacts is accomplished through proper evaluation and selection of WRAs, proper design of turbines and associated structures and pre and post construction research and monitoring.

The following list summarizes the recommendations from the USFWS interim guidelines for turbine placement. Applicable information has been provided with each listed item. 
1. Avoid placing turbines in areas of threatened or endangered species.

Western Winnebago and Central Winnebago: We did not find any records of state listed or candidates of threatened or endangered species on, or in the immediate vicinity of, the site of the above proposed project. Nor does the site appear to contain suitable habitat for such species. We made these determinations based on a review of the material you sent, aerial photographs, topographic maps and our Nebraska Natural Heritage Database.

2. Avoid placing turbines in known local bird migration pathways, areas where birds are highly concentrated, areas of known daily movement flyways and areas with high incidence of fog, mist and low visibility.

The Central Winnebago location appears to have areas of dense deciduous forest. This likely provides habitat for birds during migration and for summer nesting. This location is considered eastern of the major Missouri River Migration Corridor and is not contiguous with other similar habitat. However, this site may provide habitat for breeding and migrating birds, particularly migrating passerine and raptor species. Be aware that these birds are protected under the Migratory Bird Treaty Act.

The Western Winnebago location appears to be primarily agriculture/ragneland in nature and would therefore have very limited habitat available for migratory birds.

These sites (especially the Central Winnebago location) could potentially have high seasonal concentrations of migrating birds. The guidelines suggest that an average of three years monitoring to determine peak use dates. Consideration should be given for monitoring both before and after construction. The Commission would gladly assist with developing a monitoring plan.

3. Avoid placing near bat hibernation, breeding, colonies, migration corridors or flight paths.

The northern long-eared myotis (Myotis septentrionalis) was recorded in the vicinity of these proposed sites project. This species is typically associated with forested areas. Consideration should be given for monitoring for bat activity both before and after construction. The Commission can assist with development of a monitoring plan.

4. Configure turbine locations to avoid areas or features of the landscape known to attract raptors.

Features of the landscape include cliff edges, ridges, small, dense deciduous forests. Raptors such as red-tail hawks will also utilize high man-made perches such as power lines.

5. Configure turbine arrays to avoid potential avian mortality where feasible. For example group turbines rather than spreading them widely, and orient rows of turbines parallel to known bird movements to reduce potential bird strikes. Implement appropriate storm water management practices that do not create attractions for birds, and maintain continuous habitat for areasensitive species. 
6. Avoid fragmenting large, continuous tracts of wildlife habitat.

These areas are considered altered habitat that is fragmented by agriculture, infrastructure and urban areas.

7. Avoid placing turbines in habitat known to be occupied by prairie grouse and within 5 miles of known leks.

There are no known leks in the area.

8. Minimize roads, fences and other infrastructure. All infrastructure should be capable of withstanding periodic burning of vegetation.

9. Develop a habitat restoration plan for the proposed site that avoids or minimizes negative impacts on vulnerable wildlife while maintaining or enhancing habitat values for other species. For example, avoid attracting high densities of prey animals used by raptors.

10. Reduce availability of carrion to avoid attracting golden eagles and other raptors.

Additionally, when designing turbine design, use tubular supports with pointed tops, rather than lattice supports to minimize bird perching and nesting opportunities. Avoid placing external ladders and platforms on tubular towers to minimize perching and nesting. Avoid use of guy wires for turbine or meteorological tower supports. If taller turbine is necessary and lighting is required by the Federal Aviation Administration (FAA), the guidelines recommend that only white strobe lights be used at night, and these should be the minimum number, minimum intensity and minimum number of flashes per minute allowable by the FAA. Solid red or pulsating red incandescent lights should not be used.

Please note that this correspondence does not satisfy requirements of the Nongame and Endangered Species Conservation Act. Under the authority Neb.Rev.Stat. \$37-807 (3), all Nebraska state agencies are required to consult with the Nebraska Game and Parks Commission to ensure that any actions authorized, funded or carried out by then do not jeopardize the continued existence of a state listed species. This requirement would extend to any state permit issued. Please contact me if you need assistance with determining the potential of an action to affect listed species.

All federally listed threatened and endangered species are also state listed. For assessment of potential impacts on federally listed, candidate or proposed threatened or endangered species, please contact John Cochnar, Nebraska Field Office, U.S. Fish and Wildlife Service, 203 W. Second St., Grand Island, NE 68801.

Thank you for the opportunity to comment. If you have any questions or need additional information, please feel free to contact me.

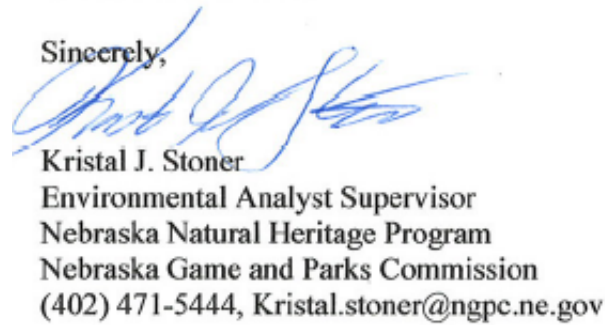


Erickson, W. P., G. D. Johnson, M. D. Strickland, D. P. Young, Jr., K. J. Sernka and R. E. Good. 2001, Avian collisions with wind turbines: A summary of existing studies and comparisons to other sourees of avian collision mortadity in the United States. National Wind Coordinating committee, Washington, D. C, USA

Hoover, S. L and M. L. Morrison. 2005. Behavior of red-tailed hawks in a wind turbine devclopment. Journal of Wildlife Management. $69(1)$; $150-159$

Johuson, G. D., M. K. Perlik, W. P. Errickson and M. D. Strickland. 2004. Bat activity, composition and collision mortality at a large wind plant in Minnesota. Wildlife Society Bulletin. 32(4): 1278-1288

Kerns J and Kerlinger P. 2004. A study of bird and bat collision fatalities at the Mountaineer Wind Energy Center, Tucker County, West Virginia, Fl'L Energy and Mountaineer Wind Energy Center 'Technical Review Committee. Cape May, NJ

Leddy, K. L, K. R. Higgins and D. E. Naugle. 1999. Effects of wind turbines on upland nesting birds in conservation reserve program grasslands. Witson Bulletin, 111(1): 100-104

Reynolds, D. S. 2006. Monitoring the potential impact of a wind development site on bats in the northeast. Journal of Wildife Management $70(5)$ : 1219 . 1227

Schmidt, E., A. J. Paggio and C.E. Block. 2003. National Wind Technology Center site environmental assessment: bird and bat use and fatalities, Final report NREL/SR-500-32981. National Renewable Energy laboratory, Golden, Colorado, USA. 


\subsection{Letter Regarding Archeological Sites}

October 23, 2008

Winnebago Tribal Council

Winnebago Tribe of Nebraska

Box 687 Blackhawk Center

Winnebago, Nebraska

Dear Council Members:

After viewing the Two Met Tower Sites with Tanya Martinez, of Red Mountain Tribal Energy on September 23, and after reviewing my own tribal records, which consisted of the 1887 Allotment Records, State Death Records, Winnebago Tribal Maps from 1910, The Farm \& Home Plat \& Directory, Oral Tradition, I founds that the construction of the Met Tower's will have no impact on Tribal Cultural Properties in the area that belong to the Winnebago Tribe of Nebraska.

The first site is located 5 miles south of Emerson, Nebraska, off High Way 9. The nearest Tribal cultural properties near this site are located 3 miles east of the proposed site. The second site is located 3 miles south of Winnebago, off High Way 77 . This site is southeast of the Kelly Housing Projects, the area known as the Kelly Subdivision. The nearest cultural properties are located 1 mile north of this site. Oral Tradition states that the second site was near an old battle field from 1865 . If you need any more information, call me at 878-2976.

Sincerely,

David Smith

Repatriation Director, Cultural Preservation Office

Winnebago Tribe of Nebraska

402-878-2976 


\subsection{Conservation Reserve Program}

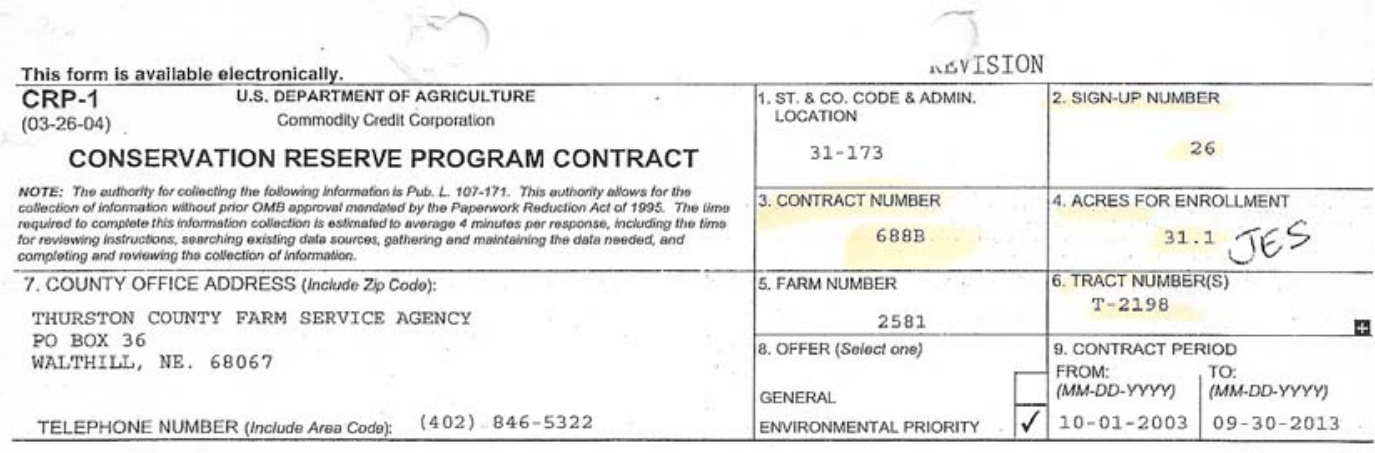

THIS CONTRACT is entered into between the Commodily Credil Corporation (referred to as "CCC") and the undersigned owners, operators, ar tenants (who may be referred to as "the Participant") The Participant agrees to place the designated acreage into the Conservation Reserve Program ("CRP" or other use set by CCC for the stipulated contract period from the date the Contractis execuled by the CCC. The Pancipant also agreas to implement on such designated acreage the Conservation Plan developed for such acreage and approved by the CCC and the Participant. Additionally, the Paricipant and CCC agree to comply with the terms and conditions contained in this Contract, including the Appendix to this Gontract, onialod Appandix. withdraws prior to CCC acceptance or refection. The terms and conditions of this contract are contained in this Form CRP-1 and in the CRP-1 Appendix and any add thereto. BY SIGNING THIS CONTRACT PRODUCERS ACKNOWLEDGE RECEIPT OF THE FOLLOWING FORMS: CRP-1; CRP-1. Appendix and any addendum thereto; CRP-2 or CRP-2C, if applicable; and, if applicable, CRP-15.

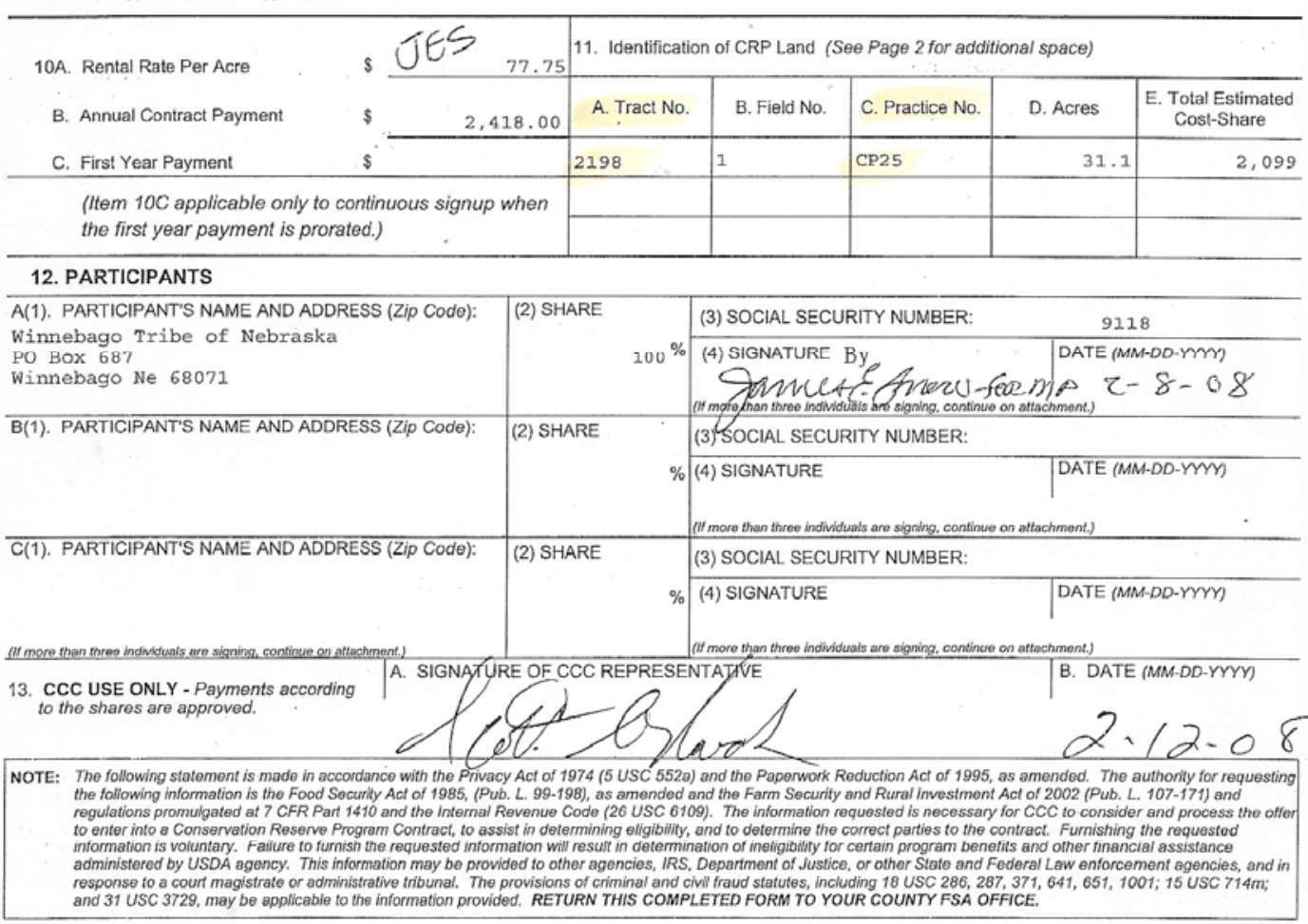

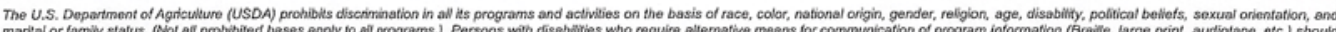

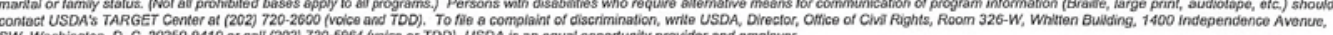
SW. Washingtan, D. C. 20250-9410 or call (202) 720.5964 (voice or TDD). USDA is an equall opportunity provider and employer.

Original - County Office Copy

Owner's Copy

Operator's Copy 


\section{FARM BILL $^{7}$}

\section{$\underline{\text { USDA's Business and Industry Guaranteed Loans Program }}$}

Extends USDA Rural Development loans and loan guarantees under the Consolidated Farm and Rural Development Act to wind energy systems (Farm Bill Section 6013). ${ }^{8}$

The percentage of guarantee, up to the maximum allowed, is a matter of negotiation between the lender and the Agency. The maximum percentage of guarantee is $80 \%$ for loans of $\$ 5$ million or less, $70 \%$ for loans between $\$ 5$ and $\$ 10$ million, and $60 \%$ for loans exceeding $\$ 10$ million.

The total amount of Agency loans is capped at $\$ 10$ million. The Administrator may, at the Administrator's discretion, grant an exception to the \$10 million limit for loans of \$25 million under certain circumstances. The Secretary may approve guaranteed loans in excess of $\$ 25$ million, up to $\$ 40$ million, for rural cooperative organizations that process value-added agricultural commodities.

\section{Conservation Reserve Program (CRP) Lands}

Allows farmers to install wind turbines on Conservation Reserve Program (CRP) lands subject to the approval of the USDA. CRP payments are not reduced based on this activity. USDA can specify the number and location of turbines and will only allow if consistent with CRP goals for the land. (Sec. 2101)

\section{Value-Added Grants}

Defines wind power located on ranches and farms as a "value-added agricultural product." This designation allows for grants up to $\$ 100,000$ for project planning activities and up to $\$ 300,000$ for working capital. Approximately $\$ 19.3$ million in competitive grant funds is available in fiscal year 2007. (Sec. 6401)

\footnotetext{
${ }^{7}$ http://www.windpoweringamerica.gov/ag farm bill.asp

${ }^{8}$ http://www.rurdev.usda.gov/rbs/busp/b\&i gar.htm
} 


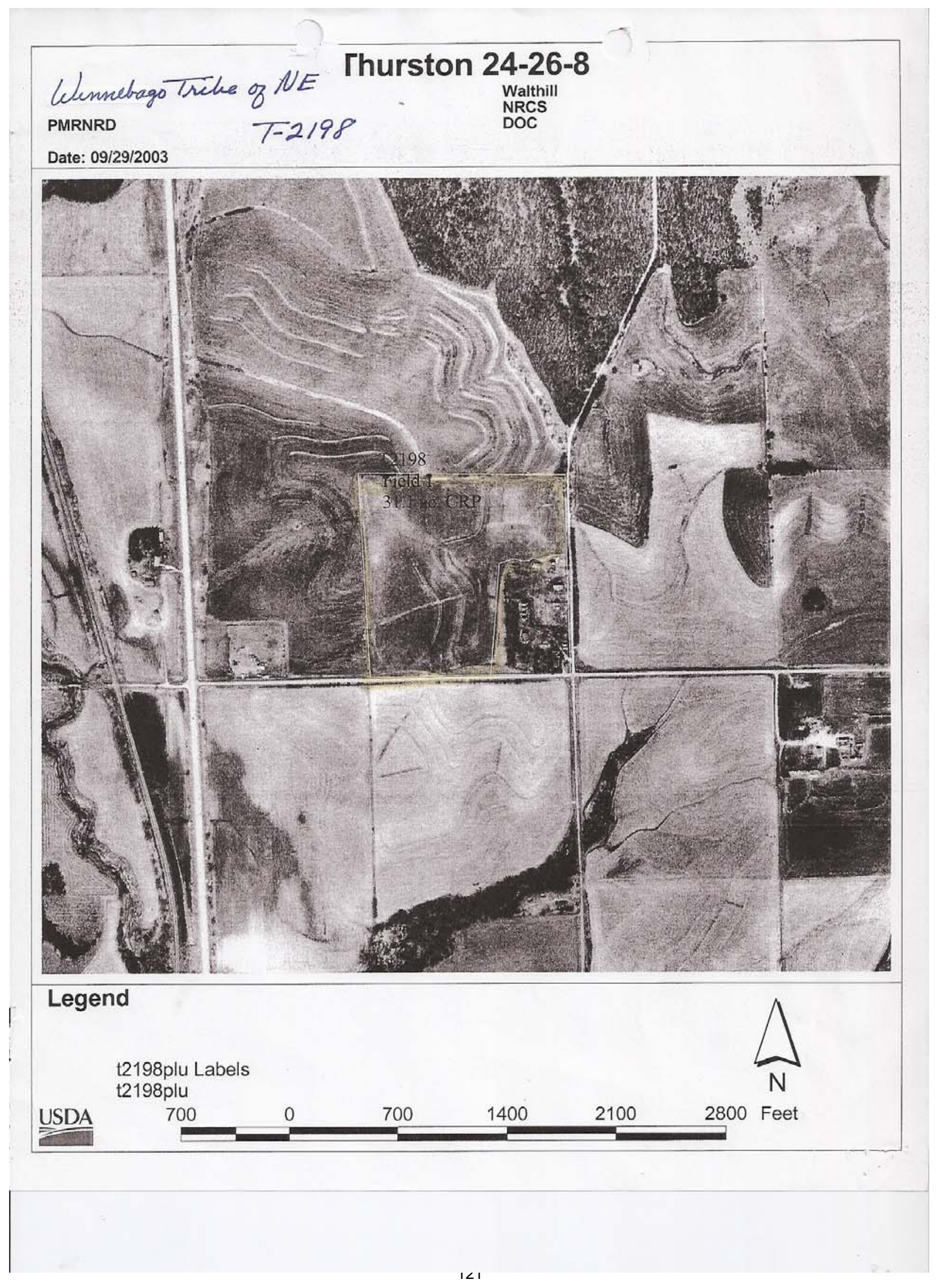




\subsection{NPPD Interconnection Request}

In order to initiate an interconnection request, the interconnection customer must submit all of the following:

- a $\$ 10,000$ deposit

- a completed application

- Demonstration of Site Control, as defined in the District Standard, or an additional deposit of $\$ 10,000$. Deposits will be applied toward the cost of the required interconnection studies

In accordance with FERC Order 2003, a request for interconnection service does not constitute a request for transmission service. Transmission service requests must be made in accordance with NPPD's T-2 Transmission Service Rate Schedule. NPPD will require that the interconnection customer submit a transmission service request before it will perform the System Impact Study. NPPD will offer Network Resource Interconnection Service, but will not offer Energy Resource Interconnection Service, as defined in FERC Order 2003. A transmission service request is required for delivery of the generation output.

\subsubsection{System Impact Study}

The System Impact Study evaluates the impact of the proposed generator interconnection on the reliability of the transmission system and requires a deposit of $\$ 50,000$. The deposit is applied to the cost of the study and a quote will be provided for the total costs. Requirements for the System Impact Study are the following:

- Facility one-line diagram depicting:

o Detailed proposed interconnection points

o Voltage levels

o Equipment data

o Breaker / switch configurations

o Protective relay zones.

- Transformer data

o Impedance

o Winding configurations

o Voltage levels

o Thermal and available tap ranges.

- Generator

o nameplate data

o machine constants

o generator voltage rating

o step-and auxiliary transformer data

o impedance data and ratings

o Generator rotor

o Governor

o Exciter

o power system stabilizer

o any other generator auxiliary data

o MW / MVAR levels 


o reactive capability curves
o operational power and proposed load factors
- Transmission line
o Configuration
o Impedance
0 thermal ratings

The system impact study entails the following:

- $\quad$ Phase 1: Powerflow screening analysis of the proposed interconnection facility.

- Phase 2: Detailed powerflow analysis, dynamic stability analysis, short circuit analysis and any other required study work. Powerflow analysis will require 10-yr load and resource growth projections.

o May be required: small signal stability studies or Electro-magnetic Transients Program (EMTP) - analyzes power quality. Evaluate alternative to proposed interconnection, such as lower voltage construction, alternative interconnection points, reactive support facilities or upgraded facilities

o Operational studies may be required to evaluate impacts on generation operations in the NPPD Control Area

- Phase 3: Facilities study will detail the final interconnection facilities design, direct assignment facilities, construction schedules, costs of the equipment, engineering, procurement and construction work needed to implement the conclusions of the System Impact Study. The Facilities study will merge the results of the System Impact studies into a final Planning / Design study which will be formatted for submittal to the MAPP Design Review Subcommittee or other regional approval authority.

o $\$ 100,000$ deposit, the District will provide an estimate of total costs

After completion of the Facilities Study, the large generator interconnection agreement (LGIA) will identify the Interconnection Facilities.

\subsubsection{Large Generator Interconnection Agreement (LGIA)}

After completion of the Facilities Study, the LGIA will identify the Interconnection Facilities, which includes both the District-owned Interconnection Facilities and Interconnection Customerowned Interconnection Facilities. Interconnection Customer-owned Interconnection Facilities means all facilities and equipment that are located between the generator and the point of change of ownership between the District and the interconnection customer. The interconnection customer will be responsible, at its expense, to obtain regulatory approvals and permits, design, procure, construct, and operate and maintain all of the customer-owned Interconnection Facilities, subject to the approval of the District. District-owned Interconnection Facilities means all facilities and equipment from the point of change of ownership to the point of interconnection to the District's transmission system. Interconnection Facilities are sole-use facilities that must be paid for by the interconnection customer.

The LGIA will also identify Network Upgrades, which means additions, modifications and upgrades to the District's transmission system required at or beyond the point of interconnection. The cost of the Network Upgrades must be paid for by the interconnection customer; however, the interconnection customer will receive a credit on its transmission 
service billing once the interconnection customer starts taking transmission service pursuant to the District's T-2 Transmission Service Rate Schedule. The credit will apply until all of the funds provided by the interconnection customer for the Network Upgrades have been paid back to the interconnection customer. Arrangements for payment by the interconnection customer for the District-owned

Interconnection Facilities and Network Upgrades will be specified in the LGIA.

1. NPPD reserves the right to participate in the costs of proposed facility expansion plans that may be accommodated through mutually advantageous alternatives which provide substantial benefits to regional reliability or transmission transfer capability. The District will provide a credit for the cost of the network upgrades funded by the interconnection customer, and apply this credit against transmission service charges under the District's T-2 Transmission Rate Schedule until the total amount of the cost of the network upgrades has been paid back. 


\section{Career Training and Workshops}

lowa Lakes Community College is working to help meet the growing demand for skilled technicians who can install, maintain, and service modern wind turbines. The Wind Energy and Turbine Technology Program is the first in the state of lowa. The diploma program consists of the first three terms. In addition to the coursework listed in the first three terms Business Communications is also required for the diploma. To prepare for entry-level positions in the industry, you will receive training in:

- construction

- maintenance

- operation of wind turbines

Earning the Associate in Applied Science Degree consists of completing the second year of the program. You will receive additional training on:

- diagnosis of turbines

- high tech-low voltage

- computerized control and monitoring systems

- composites and composite repair

- data acquisition

- management of people

As a graduate of the two-year degree program you qualify for entry-level positions and also have the skills and education background to become a wind turbine operator and potentially a supervisor.

Algebra skills are essential to successful completion of the program. Assessment scores must indicate readiness for Intermediate Algebra. If you aren't able to enroll in this course, you will be accepted into the Wind Energy General Studies Track until you can meet this requirement.

http://www.iowalakes.edu/programs_study/industrial/wind_energy_turbine/index.htm

Contact: Angie DeJong

Office Associate for Wind Energy

712-362-7931

adejong@iowalakes.edu

MINNESOTA WEST COMMUNITY AND TECHNICAL COLLEGE

The Minnesota West Community College offers the "Windsmith" program that covers wind turbine installation, repair and troubleshooting.

http://www.mnonline.org/progDetail.php?sch=60021\&prog=46.039901\&award=Certificate 


\section{SOLAR ENERGY INTERNATIONAL}

Solar Energy International offers a variety of renewable energy training workshops. Check schedule for a list of workshops. The wind specific workshops currently being offered are for residential wind power design and installation, maintenance and repair and building wind generators from scratch. Workshops are in the price range of $\$ 600-\$ 850$. See website: http://www.solarenergy.org/. Wind turbine installation and construction workshops

\section{MIDWEST RENEWABLE ENERGY ASSOCIATION}

The Midwest Renewable Energy Association offers a variety of trainings from basic introductory courses at $\$ 90$ to installation training for $\$ 600$.

http://www.the-mrea.org/course_workshops.php 